
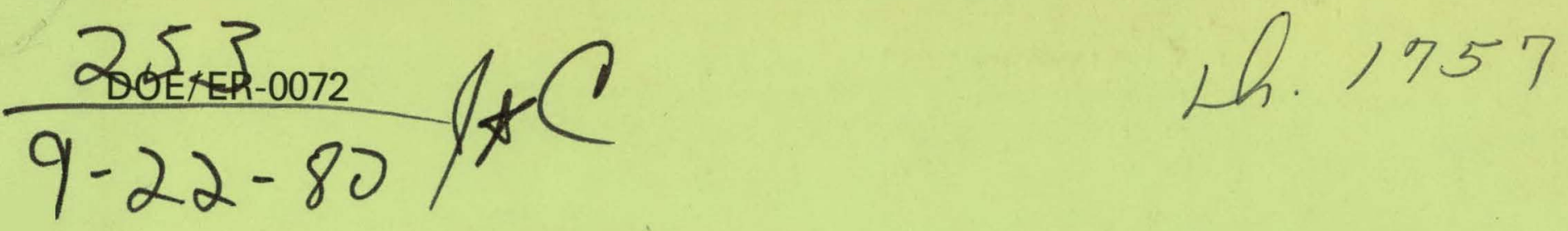

\title{
Prototype Environmental Assessment of the Impacts of Siting and Constructing A Satellite Power System (SPS) Ground Receiving Station (GRS)
}

August 1980

Prepared for:

U.S. Department of Energy

Office of Energy Research

Satellite Power System Project Division

Under Contract No. 31-109-38-5251

DOE/NASA

Satellite Power System

Concept Development

and

Evaluation Project 


\section{DISCLAIMER}

This report was prepared as an account of work sponsored by an agency of the United States Government. Neither the United States Government nor any agency Thereof, nor any of their employees, makes any warranty, express or implied, or assumes any legal liability or responsibility for the accuracy, completeness, or usefulness of any information, apparatus, product, or process disclosed, or represents that its use would not infringe privately owned rights. Reference herein to any specific commercial product, process, or service by trade name, trademark, manufacturer, or otherwise does not necessarily constitute or imply its endorsement, recommendation, or favoring by the United States Government or any agency thereof. The views and opinions of authors expressed herein do not necessarily state or reflect those of the United States Government or any agency thereof. 


\section{DISCLAIMER}

Portions of this document may be illegible in electronic image products. Images are produced from the best available original document. 


\section{NOTICE}

This report was prepared as an account of work sponsored by the United States Government. Neither the United States nor the United States Department of Energy, nor any of their employees, makes any warranty, express or implied, or assumes any legal liability or responsibility for the accuracy, completeness, or usefulness of any information, apparatus, product, or process disclosed, or represents that its use would not infringe privately owned rights. Reference herein to any specific commercial product, process, or service by trade name, mark, manufacturer, or otherwise, does not necessarily constitute or imply its endorsement, recommendation, or favoring by the United States Government or any agency thereof. The views and upiniunss of authors expressed herein do not necessarily state or reflect those of the United States Government or any agency thereof.

Ava1lable from:

National Technical Information Service (NTIS

v.S. Department of Commerce

5285 Port Royal Road

Springfield, Virginia 22161

Price: Printed Copy:

Microfiche: $\quad \begin{aligned} & \$ 15.00 \\ & \$ 4.00\end{aligned}$ 


\section{Prototype Environmental Assessment of the Impacts of Siting and Constructing A Satellite Power System (SPS) Ground Receiving Station (GRS)}

August 1980

Prepared for:

U.S. Department of Energy

Office of Energy Research

Satellite Power System Project Division

Washington, D.C. 20585

Prepared by:

Environmental Resources Group

Lus Angeles, Ca. 90048

Under Contract No. 31-109-38-5251

DOE/NASA

Satellite Power System

Concept Development

and

Evaluation Project

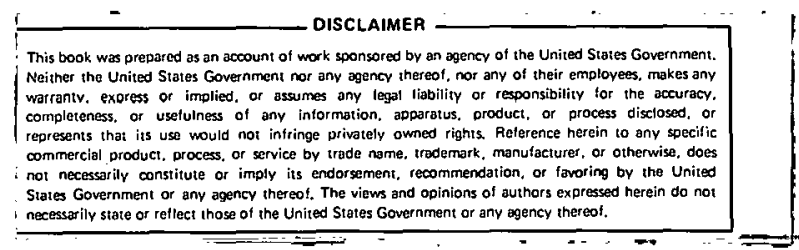

This book was prepared as an account of work sponsored by an wort

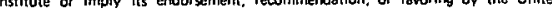
Stere or reflect those of the United States Government or any tegency thereol. 


\section{ABSTRACT}

This report-is a prototype assessment of the environmental and societal impacts of a Satellite Power System (SPS) Ground Receiving Station (GRS) (The term GRS here refers to the overall facility that includes the rectenna, which actually receives and rectifies the microwave energy, as well as support facilities, access roads, a buffer zone, etc. in addition to the rectenna itself.) The study objectives are: 1) to develop a comprehensive prototype assessment of the non-microwave-related impacts (microwave health and safety and communications effects, etc. are not addressed) on the natural and human environments of the reference system SPS GRS; 2) to assess the impacts of GRS construction and operations in the context of actual baseline data for a site in the California desert (about $250 \mathrm{kilometers} \mathrm{north} \mathrm{of} \mathrm{Los} \mathrm{Angeles)}$ which, while it has not been. selected as eligible for GRS siting, has many features that are optimal for SPS; and 3) to identify critical GRS characteristics or parameters that are most significant in terms of both the natural and human environment.

Critical project parameters revealed include: the sheer size and intensivity of use of the contiguous land area required by an SPS GRS; the lack of flexibility in siting individual rectenna structures once the rectenna boundaries are established; the difficulties in finding suitable sites that do not conflict with other societal needs and values; uncertainties relating to reestablishing native ecosystems following total ecosystem modification during construction, and the related need for further research into microclimatic effects near the ground-surface beneath the rectenna panels; the proposed two-year GRS construction schedule, which has significant implications for project socioeconomic impacts, regional availability/price of construction materials such as cement, aggregate and steel, air quality, water supply and biological resources and possible logistic problems for GRS construction all of which could be reduced by extending the construction schedule; and public versus private GRS ownership, which has significant implications for GRS impacts on the local tax base. 
Funding for this report was provided through two separate contracts: one with Argonne National'Laboratory (Contract No. 31-109-38-5251) as part of the Environmental Assessment study effort of the overall SPS Concept Development and Evaluation Program (CDEP) and one with PRC Energy Analys is Co. (Purchase Order No. W5153) as part of the Societal Assessment portion of the SPS CDEP. The report sections addressing air quality/climatology, noise, soils/geology, water quality/hydrology, and biology (Sections 3.1-3.9 and 4.2-4.7) were funded under the ANL contract; the sections addressing land use, socioeconomics, cultural resources, visual resources and electricity supply and deilland (Sections 3.10-3.14 and 4.8-4.12) were funded under the PRC contract.

The results of these two contracts are combined into a single report assessing GRS impacts on the human, physical and biological environment. This approach yields a single, comprehensive prototype Environmental Assessment docurnent, which addresses each of the technical areas normally covered in a federally mandated Environmental stätement.

Major contributors to this report included:

Mr. Arrie Bachrach; Program Manager

Dr. John Hill, Technical Manager

Mr. Gary Meunier

Mr. James Rabe

Mr. Keith Julian

Mr. Hamid Rastegar

Ms. Suzanne Phinney

Mr. David Morycz

Ms. Gail Jensen

Mr. Robert Klein

Mr. Richard Weiss (Harding-Lawson Associates) 
METRIC - ENGLISH CONVERSIONS

ONE TONNE

ONE KILOGRAM

ONE LITER

ONE HECTARE

ONE METER (m)

ONE KILOMETER ( $\mathrm{km})$

ONE LITER FUEL

ONE ACRE-FOOT

$$
\begin{aligned}
& =1.102 \text { TONS OR .2205 POUNDS } \\
& =2.205 \text { POUNDS } \\
& =0.264 \text { GALLONS } \\
& =\quad 2.471 \text { ACRES } \\
& =3.281 \text { FEET } \\
& =0.621 \text { MILES } \\
& =\quad 0.85 \text { KILOGRAM FUEL } \\
& =1233 \text { CUBIC METERS }
\end{aligned}
$$


S: EXECUTIVE SUMMARY

1.0 INTRODUCTION

1.1 THE SATELLITE POWER SYSTEM CONCEPT DEVELOPMENT AND EVALUATION PROGRAM

1.2 OBJECTIVES : $\ldots \ldots$

1.3 SCOPE 2

1.4 CONSTRAINTS 4

1.4.1 GRS Description Data 4

1.4.2 The Rose Valley/Coso Site : $\therefore 5$

2.0 DESCRIPTION OF THE PROPOSED ACTION

2.1 DESCRIPTION OF THE GROUND RECEIVING STATION .10

2.1.1 Rectenna Field General Description 10

2.1.2 Rectenna Field Component Descriptions ' 10

2.1.2.1 Panel Components 10

2.1.2.2 Support Structures and.

2.1.3 Electric Power r.ollection System . . 11

2.1.4 Permanent Ancillary Facilities 11

is $\quad 2.1 .5$ Ground Receiving Station Operations : 14

2.2 GROUND RECEIVING STATION CONSIRUCTION 16

2.2.1 ... Introduction 16

2.2.2. : Prel iminary Construction Activities 16

2.2.3 Rectenna Field Site Preparation 19

2.2.4 Rectenna Construction 19

$\because \quad 2.2 .4 .1$ : Support Structure Manifarture

2.2.4.1 : $\begin{aligned} & \text { Support Structure Manufacture } \\ & \text { and Installation }\end{aligned}$

2.2.4.2 Rectenna Panel Manufacture
and Installation

3.

2.2.5 Electric Power Collection System 21

2.2.6. .... Additional Construction and PreConstruction Activities

2.2.7 Summary of Major Construction Requirements

2.2.7.1 Labor Requirements " 24

2.2.7.2 Materials Requirements 24

2.2.7.3 Utility Requirements 28 
2.2.7.4 Vehicle and Equipment Requirements and Fuel Consumption 28 2.2.7.5 Sol id and Liquid Wastes . . $\quad 28$ 2.2.7.6 Construction Costs 28

2.3 ELECTRIC POWER TRANSMISSION SYSTEM

2.3.1 Introduction 31

2.3.2 Electric Power Transmission System Construction

3.0 PRESENT ENVIRONMENT $\quad 34$

3.1 INTRODUCTION $\quad 34$

3.2 CLIMATOLOGY $\quad \cdots \quad: \quad \cdots \quad 34$

3.3 AIR QUALITY 37

3.4 NOISE : $\quad 39$

3.5 GEOLOGY $\quad 41$

3.5.1 Regional Geology 41

3.5.2 Local Geology : 43

3.5.3 Seismicity . . . . 43

3.5.4 Mineral Resources 44

3.6 SOILS $\quad 44$

3.7 HYDROLOGY/WATER QUALITY $\quad 47$

3.7.1 Surface Water $\quad 47$

3.7.1.1 Watershed Features 47

3.7 .1 .2 Surface Water Quality " 48

3.7.1.3 Erosion . 48

3.7.2 Groundwater $\quad 52$

3.7.3 ${ }^{\cdots}$ Water Chemistry and Quality . 52

3.7.4 Hydrologic Balance 53

3.7 .5 " Water Availability and Use. . $\vdots \vdots$

3.8 FLORA 55

3.8.1 Dominant Component Plant Species/

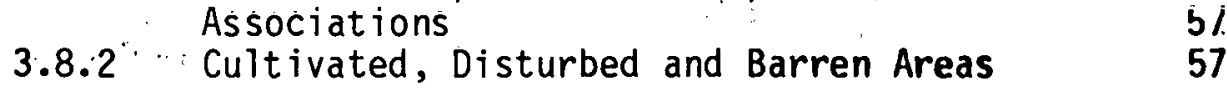

3.8.3 Summary of Sensitive Floral Areas 58

3.8.4 Rare and Locally Endemic Plants $\quad \therefore \quad 58$ 
TABLE OF CONTENTS (continued)

$\underline{\text { Page }}$

3.9 WILDLIFE 60

3.9.1 Aquatic Wildlife and Habitats 60

3.9.2 Amphibian and Reptilian Wildlife and $\quad 62$

3.9.3 Avian Wildlife and Habitats . 62

3.9.4 Mammalian Wildlife and Habitats 62

3.9.5 Sensitive Wildlife Areas and Habitat Types 63

3.9.6 Endangered, Threatened and Rare Species 64

$\begin{array}{ll}3.10 & \text { LAND USE }\end{array}$

3.10.1 Historical Land Use Trends 64

3.10.2 Summary of Present Land Uses and Land
Use Trends

3.10.3 Land Ownership and Administrative Patterns 70

3.10.4 Present Land Use Policies, Plans and

Permitted Uses 72

3.11 SOCIOECONOMICS 72

3.11.1 Population 72

$\begin{array}{lll}3.11 .2 & \text { Housing } & 75\end{array}$

$\begin{array}{lll}3.11 .3 & \text { Infrastructure } & 77\end{array}$

3.11.3.1 Police Protection 77

3.11.3.2 Fire Protection 77

3.11.3.3 Eletrical Utility : 77

3.11.3.4 Freshwater Supply. 77

3.11.3.5 Gas Utility 77

3.11.3.6 Sewage/Wastewater Treatment 78

3.11.3.7 Solid Waste Disposal 78

3.11.3.8 Health and Mental Health Systems . 78

3.11.3.9 Education Systems 78

3.11.3.10 Social Service Systems 79

3.11.3.11 Recreation 79

3.11.4 Traffic and Transportation Systems 79

3.11.4.1 Recreational Trafflc 79

3.11 .4 .2 . Truck Traffic 79

3.11.4.3 Rail Trarspurtation 79

3.11 .4 .4 Public Transportation 01

3.11.4.5 Air Transportation 81

3.11 .5 Economics $\quad$ : 11

3.11.5.1 Employment 81

3.11.5.2 Income 81

3.11 .5 .3 Major Industry 81

3.11 .5 .4 Public Revenues $\quad 84$

3.11.5.5 Public Expenditures 84 
TABLE OF CONTENTS (continued)

3.11.6 Public Attitudes 84

3.11.7 Native American Concerns 87.

3.12 CULTURAL RESOURCES $\quad \because \quad 88$

3.12.1 Prehistory. 88

3.12.2 Ethnography and Historic Period 89

3.12.3 Cultural Resources Inventory 90

3.13 VISUAL RESOURCES

3.13.1 Landscape Character 91

3.13.2 Visual Resources Inventory 91

3.14 ELECTRICITY SUPPLY AND DEMAND . 94

4.0 ENVIRONMENTAL IMPACTS 95

$\begin{array}{lll}4.1 & 95\end{array}$

4.2 AIR QUALITY/CLIMATOLOGY 96

4.2.1 Introduction 96

4.2.2 Emissions Inventory 96

4.2.2.1 Site Clearing and Grading 96

4.2.2.2 Support Structure and Manu-
facture and Installation

4.2.2.3 Transportation of Construction
Materials

4.2.2.4 Workers' Vehicles 105

4.2.2.5 Power Generation 105

4.2.3 Impacts of Ambient Air Quality 105

4.2.3.1 Modeling Approach 111

4.2.3.2 Modeling Results 111

4.2.4 Climatology 112

4.2.5 Mitigation 114

4.3 NOISE "115

4.3.1 Assumptions, Approach and Noise Emissions 115

4.3.2 Expected Noise Levels of GRS Development 119

4.3.3 Mitigation 122

4.4 GEOLOGY/SOILS $\quad 122$

4.4.1 Geologic Impacts and Constraints 124 
4.4.1.1. Introduction 124

4.4.1.2 Seismic Hazards 124

4.4.1.2.1 Ground Shaking 125

4.4.1.2.2 Surface Faulting 127

4.4.1.2.3. Other Ground Failure Induced by Shaking 128

4.4.1.3 Landsliding 128

4.4.2: Soils Impacts and Constraints $\quad 128$

4.4.2.1 Introduction 128

4.4.2.2 likS linnstruction Impacts 129

4.4.2.3 GRS Operations Impacts 129

4.4.2.4 Soils Constraints 130

4:4.3 Geology/Soils Mitigation . . . . . 131

4.5 HYDROLOGY/WATER QUALITY 132

4.5.1. Introduction 132

4.5.2 Water Consumption and Availability 133

4.5.3 Degradation of Natural Water Quality 136

4.5.4 Surface Runoff 137

$\mathbf{4 . 5 . 5}$ Mitigation. 138

4.5.5.1 Lowering of Rose Valley Water

Table 138

$\begin{array}{ll}\text { 4.5.5.2 Degradation of Natural Water. } & 138 \\ \text { Quality } & \end{array}$

4.5.5.3 Tlood Hazard $\quad 139$

$\begin{array}{lll}4.6 & \text { FLORA } & 139\end{array}$

4.6.1 Generalized Impacts on Plant Communities 139

4.6.1.1 Construction Phase 139

4.6.1.2 Operations Phase : $\therefore 140$

$\begin{array}{lll}\text { 4.6.1.3 Indirect Impacts-Construction } & \\ & \text { and Operations } & 141\end{array}$

4.6.2 Impacts on Sensitive Floral Areas and

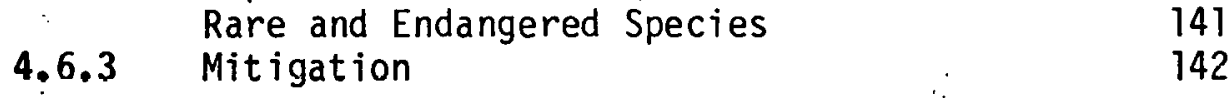

4.6.3.1 Construction Phàse 142

4.6.3.2 Operations Phase : 143

4.7 FAUNA 144

4.7.1 Generalized Impacts to Faunal Communities 144 
4.7.1.1 Construction Phase 145

4.7.1.2 Operations Phase 145

4.7.1.3 Summary of Direct Land

Disturbance Impacts by Taxa-

Construction and Operations

4.7.1.4 Indirect Impacts-Construction and Operations

4.7.1.5 Summary of Indirect Impacts by Taxa-Construction and Operations

146

146

147

4.7.2 ... Impacts to Sensitive Faunal Areas and Rare and Endangered Species

4.7.3 Mitigation, ...

4.7.3.1 Construction Phase

150

4.7.3.2 Operations Phase

150

4.8 LAND USE

4.8.1 Introduction

4.8.2 Direct Impacts

154

4.8.2.1 New Use Direct Impacts .:- 154

4.8.2.2 Direct Dis.placement 'Impacts 156

4.8.3 Indirect Impacts $\ldots \quad \ldots$

4.8.3.1 New Use Indirect Impacts 157

4.8.3.2 Indirect Displacement Impacts 158

4.8.4 Non-Quantifiable Impacts and Issues 158

4.8.5 Mitigation 162

4.8.5.1 Mitigation of Direct Impacts $\quad 162$

4.8.5.2 Mitigation of Indirect Impacts 163

4.8.5.3 Mitigation. of Subjective Land Use Conflicts and Issues 163

4.9 SOCIOECONOMICS 164

$\begin{array}{rlll}4.9 .1 & \text { Population } & 165\end{array}$

: 4.9.1.1 Construction 1:. ..... 165

4.9.1.2 Operations .... 166

4.9.2 Housing 166

4.9.2.1 Construction ... $\quad 166$

4.9.2.2 Operations 169 
TABLE OF CONTENTS (continued)

4.9.3 Infrastructure $\quad .170$

4.9.3.1 Police Protection 170

4.9.3.2 Fire Protection 170

4.9.3.3 Electrical Utility 171

4.9.3.4 Freshwater Supply 171

4.9.3.5 Sewage/Wastewater Treatment 171

4.9.3.6 Sol id Waste Disposal 172

4.9.3.7 Health/Mental Health Systems 172

4.9.3.8 Educational Systems. 172

4.9.3.9 Recreation 173

4.9.4 Traffic and Transportation Systems. 173

4.9.4.1 Construction $\quad 173$

4.9.4.2 Operations 175

4.9.5 Economics 176

4.9.5.1 Introduction $\quad 176$

4.9.5.2 Empl oyment $\quad 176$

4.9.5.3 Business Activity 177

4.9.5.4 Public Fiscal Effects 180

4.9.5.4.1 Property Tax Revenues 183

4.9.5.4.2 Public Service Costs 183

4.9.5.5 Private Ownership 186

4.9.5.6 Boomtown Effects 187

4.9.6 Mitigation 187

4.10 CULTURAL RESOURCES 188

4.10.1 Introduction 188

4.10.2 Summary of Cultural/Historical Resources 189

4.10.3 Cultural Resources Likely to be Impacted 191

4. 10.3.1 Ground Disturbance (Direct)

Impacts 197

4.10.3.2 Indirect Impacts 191

4.10.3.3 Native American Cultural Values and Concerns 193

4.10.4 Mitigation ; ; : 193

4.10.4.1 Avoidance/Realignment/Re-Siting 193

4.10.4.2 Protection through Design and

Construction Flexibility 193

4.10.4.3 Resource Survey and Mapping 194 
TABLE OF CONTENTS (continued)

Page

4.10.4.4 Resource Burial and Vertical

4.10.4.5 Recovery/Salvage of Resources

4.10.4.6 Indirect Impact Mitigation

194

194

194

4.11 VISUAL RESOURCES .

4.11:1 Visual Impacts 195

4.11.2. Mitigation 197

4.12 ELECTRICITY SUPPLY AND DEMAND ; $\quad 197$

4.12.1 Introduction and Approach 197

4.12.2: Competitive Position of SPS Power... 198

4.12.3 Capacity Growth and the Integration of
an SPS Facility

4.12.4 Other Types of Generating Facilities

Potentially Displaced by the SPS

199

4.13 TRANSMISSION LINE IMPACTS 200

5.0 SUMMARY OF IMPACTS $\quad \because \quad 202$

6.0 CRITICAL PROJECT PARAMETERS $\quad 208$

6.1 INTRODUCTION $\cdots$

6:2 SIZE AND INTENSITY OF GRS LAND REQUIREMENTS 208

6.2.1 Lack of Flexibility in Siting Rectenna Field Elements 208

6.2.2 Siting-Related Land Use Conflicts : * 208

6.3 BIOLOGICAL IMPACTS

6.4 ARCHAEOLOGICNL IMPACTS . $\cdot \cdots \cdot \cdot \cdot \cdots$

6.5 SITE SELECTION IMPL ICATIONS OF. GRS LAND USE, ..
BIOLOGY AND ARCHAEOLOGY IMPACTS .

6.6 WATER REQUIREMENTS $\quad \because \because \therefore$

6.7 ENGINEERING IMPLICATIONS OT GRS. SITE SIZE 211

6.8 GRS 24-MONTH CONSTRUCTION SCHEDULE 211

6.8.1. Socioeconomic Impacts $\because \quad \cdots \quad \therefore \quad 212$

6.8.2 Air Quality, Water Resource and Biological Implications 212

6.8.3 Logistical Problems for GRS Construction 212

6.8.4: Resource Impacts 213 
TABLE OF CONTENTS (continued)

Page

$\begin{array}{llll}\because & 6.9 & \text { PUBLIC VS. PRIVATE OWNERSHIP } & 213\end{array}$

6.10 PANEL AND ARCH DESIGN 213

$\begin{array}{ll}\text { BIBLIOGRAPHY AND PERSONS CONTACTED } & 215\end{array}$

APPENDIX A: GRS CONSTRUCTION DATA DERIVATION A-1

APPENDIX B: SOCIOECONOMIC ASSUMPTIONS

i

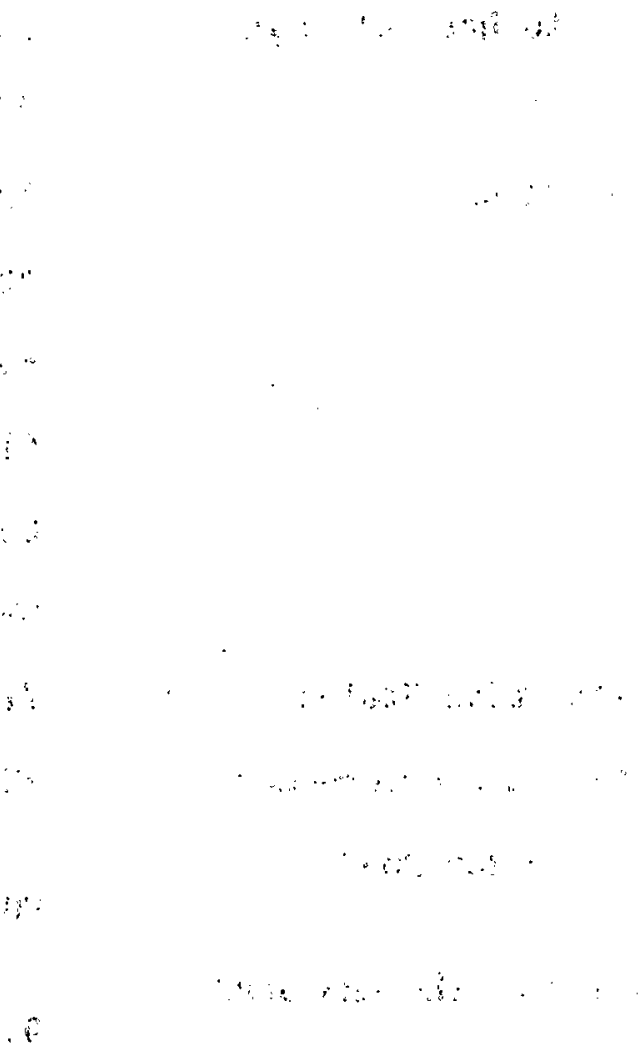




\section{LIST OF FIGURES}

Page

1.4-1 Location of GRS Study Area

1.4-2 Rectenna Placement within Rose Valley · : $\quad 7$

1.4-3 Typical Landscape within Rose Valley GRS Study Site 8

2.1-1. Two-Panel Rectenna Module and Support Structure 12

2.1-2 Rectenna Arch 12

2.1-3 Electric Power Collection System Schematic Diagram 13

2.2-1 Schedule of Major GRS Construction Activities 17

2.2-2 GRS Construction Phase: Schematic Layout 20

2.2-3 GRS Construction Phase Labor Requirements 25

2.2-4 GRS Monthly Construction Vehicle and Equipment
Requirements and Associated Fuel Consumption

2.2-5 GRS Construction Labor Costs 30

3.1-1 Location of GRS Study Area Relative to Natural Regions 35

3.1-2 GRS Study Area and Associated Features . . 36

3.5-1 Historical Seismicity of the Study Region 42

3.6-1 GRS Site Soil Map Units $\quad 45$

3.8-1 Sensitive Vegetation Areas 59

3.9-1 Sensitive Wildlife Habitat Areas 61

3.10-1 Wilderness and Wilderness Study Areas 66

3.10-2 Present Land Uses within the Study Area 69

3.10-3 Regional Land Ownership and Administrative Status 71

3.11-1 Socioeconomic Study Region and Geographic References, $\quad 73$

3.11-2 1978 Annual Average Daily Traffic on Major Roads within Study Area

80

3.13-1 Generalized. Visual Resource Inventory of the GRS Study
Area 
LIST OF FIGURES (continued)

4.3-1 Addition of Two Sound Pressure or Intensity Levels

4.4-1 Recurrence Curve for Earthquakes in the Southern Sierra Nevada. Region

4.8-1 Impacts of New Land Uses

155

4.9-1 Annual Average Daily Traffic and Project-Related Traffic Impacts on Major Roads within Study Area

4.10-1 Cultural. Resources Impacted

190

4.11-1 Visual Resource Impacts within GRS Site 196 
2.1-1 GRS Operations Requirements

2.2-1 Requirements for Materials, Labor, Vehicles and Equipment for Rectenna Support and Panel Manufacture and Installation.

22

2.2-2 Materials Requirements for GRS Construction 26

2.2-3 Requirements for Construction of 1,600 Kilometers of $500 \mathrm{kV}$ ac Transmission Lines

3.3-1 Summary of GRS Study Area Air Quality Data · 38

3.3-2 Emission Rates within the GRS Study Area 40

3.7-1 Average Annual Precipitation and Runoff in the GRS Study Area

3.7-2 Chemical Analyses for Typical Study Area Waters 50

3.7-3 Estimates of Runoff from Watershed in the GRS

Vicinity for the 100-Year Design Storm

3.7-4 Estimated Hydrologic Balance for Rose Valley 54

3.7-5. Estimated Water Use in Rose Valley 56

3.10-1 Summary of Present Regional "Urbanized Area" Land Uses

3.10-2 Summary of Present GRS Site'Land Uses 68

3.11-1 Study Region Population Data: 1960, 1970 and $1977 \quad 74$

3.11-2 Population Characteristics of Ridgecrest, China Lake, Inyo County and Cal ifornia, 1970

3.11-3 Employment by Sector 82

3.11-4 Labor Force and Unemployment, 1970 and $1977 \quad 83$

3.11-5 Study Area Income Levels 83

3.11-6 Summary of General Revenues: Fiscal Year 1977-78 85

3.17-7 Summary of General Expenditures: Fiscal Year 1977-78 86

3.13-1 BLM Visual Resource Classification System 92 
LIST OF TABLES (continued)

4.2-1 Emission Factors for Heavy-Duty Construction Equipment

Page

4.2-2 Maximum Daily and Hourly Emissions Associated with Rectenna Site Clearing and Grading

4.2-3 Emission Factors for Equipment to be Used in Support Structure Manufacture and Installation

100

4.2-4 Emissions Associated with Support Structure Manufacture and Installation

101

4.2-5 Locomotive and Truck Emission Factọrs

102

4.2-6 Maximum Daily Emissiuilis Assucialed with the Delivery of Construction Materials

4.2-7 Maximum Hourly Emissions Associated with the Delivery of Construction Materials

4.2-8 Light-Duty Vehicle Emission Factors

4.2-9 Maximum Daily and Hourly Emissions Associated with Workers Vehicles

4.2-10 Power Generation Emission Factors

108

4.2-11 Maximum Daily and Hourly Emissions Associated with Construction Power Generation

4.2-12 Summary of Maximum Daily and Hourly Emissions Associated with likS Construction

4.2-13 Air Quality Impacts of GRS Construction

4.3-1 Typical Noise Levels Associated with Construction Equipment/Operations Necessary for Rectenna Fteld Site Preparation and Support Structure Manufacture and Installation

4.3-2 Decrease in Noise Levels with Distance from the Source

4.3-3 Typical Sound Levels of Various Noises

4.3-4 Permissible Noise Exposures in Occupational Settings

4.5-1. Annual Water Consumption During GRS Construction

4.8-1 Summary of Significant Quantifiable Direct Land Use Impacts 
LIST OF TABLES (continued)

Page

4.8-2 Summary of Significant Quantifiable Direct Land Use Impacts

4.8-3 Summary of Significant Non-Quantifiable Land Use Issues and Impacts

4.9-1 Construction and Operations Phase Population . Impacts

167

4.9-2 Permanent Housing Requirements of GRS Construction and Operation

4.9-3 Project Employment Impacts

178

4.9-4 Local Payroll Spending During Construction 179

4.9-5 Local Payroll Spending During Operations 131

4.9-6 Public Revenues Temporary 182

4.9-7 Public Revenues and Costs - Permanent 184

4.9-8 Project-Generated Property Tax Revenues 1.85

4.10-1 $\begin{aligned} & \text { Significant Disturbances of GRS Site Cultural } \\ & \text { Resources }\end{aligned}$

5.1-1 Summary of GRS Construction and Operations Phase Environmental Impacts 


\section{EXECUTIVE SUMMARY}

\section{INTRODUCTION}

This report is a prototype assessment of the environmental and societal impacts of siting, constructing and operating a Satellite Power System (SPS) Ground Receiving Station (GRS). The GRS is composed of a receiving antenna (rectenna) which would receive and rectify microwave energy beamed to the earth's surface from an orbiting satellite, as well as electric power collection and transmission facilities, a control center, support facilities, access roads, etc. Each GRS would provide 5,000 megawatts (five gigawatts) of electrical power to the utility grid.

This study comprises a portion of both the Environmental Assessment and Societal Assessment study tasks of the overall Department of Energy/National Aeronautics and Space Administration SPS Concept Development and Evaluation Program (CDEP). This report represents two separate studies combined into one report: one addressing GRS impacts on the natural environment (part of the Environmental Assessment task), the other addressing impacts on the human environment (part of the Societal Assessment task). A single combined report has been prepared because comprehensive environmental assessments address the interrelated impacts of a project on both the natural and human environments in an integrated fashion.

OBJECTIVES, SCOPE AND CONSTRAINTS

The objectives of this study are:

- To develop a comprehensive prototype assessment of the non-microwaverelated impacts (microwave health and safety and communications effects, etc. are not addressed) on the natural and human environment of the reference system SPS GRS.

- To assess the impacts of GRS construction and operations in the context of actual baseline data for a site in the California desert about 250 kilometers north of Los Angeles referred to as Rose Valley (the specific. GRS study site)/Coso (general vicinity). (Figure S-1 is a map showing the study area location.)

- To identify critical GRS characteristics or parameters that are most significant in terms of both the natural and humain environment.

This prototype environmental study includes each of the basic elements commonly found in a formal Environmental Statement: a description of the proposed action, a description of the present environment of the siting area, an assessment of impacts and identification of possible mitigation measures.

SPS concept definition efforts to date have not addressed GRS construction in sufficient detail to provide much of the descriptive data (project features that generate air emissions, land surface disturbance, water consumption, waste production, etc.) needed for this prototype assessment. Additional needed data were developed through extrapolation and use of estimation factors obtained from environmental and engineering feasibility studies for other 


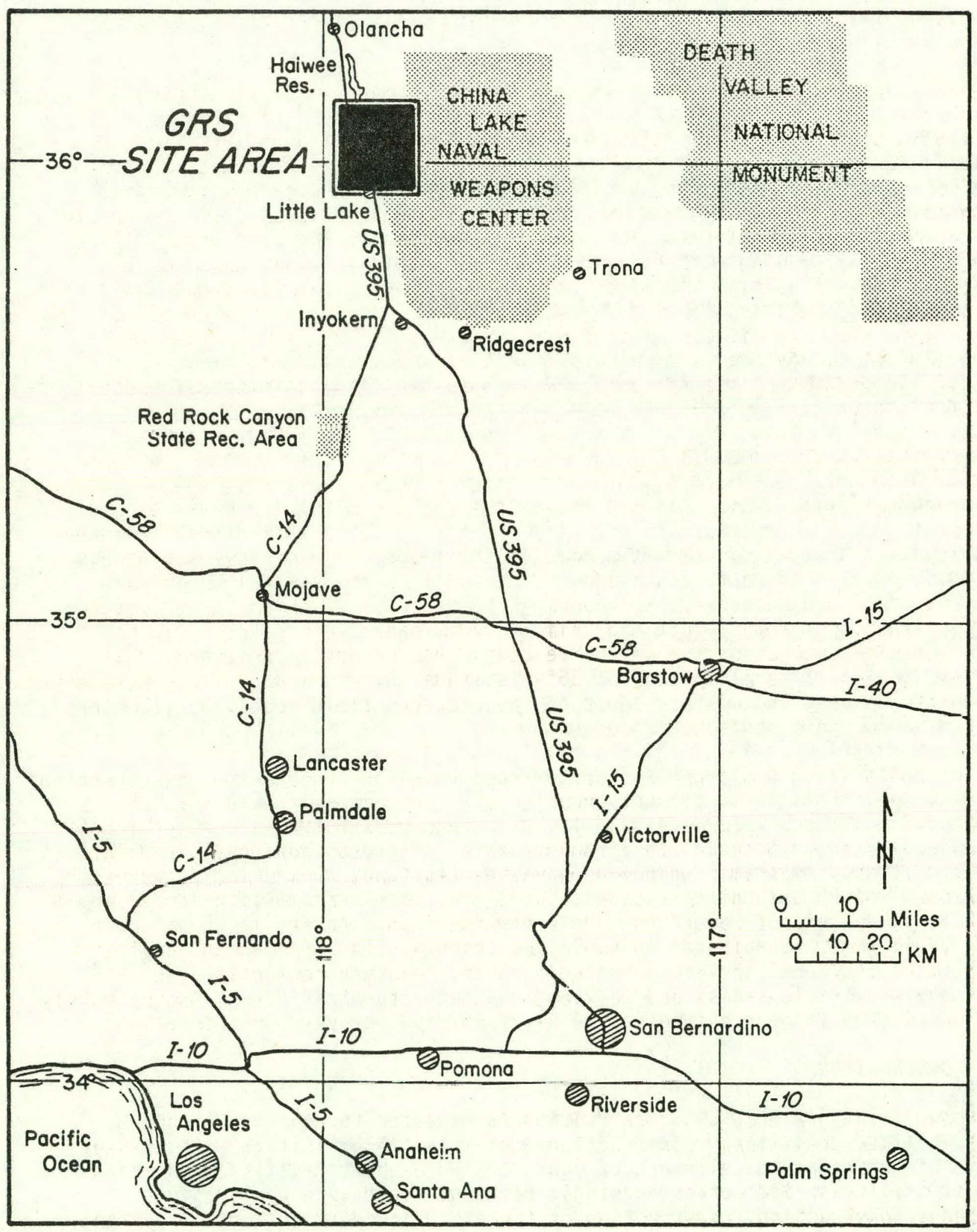

Figure S-1. LOCATION OF GRS STUDY AREA 
large energy projects, engineering handbooks, other standard reference documents, and discussions with major construction and engineering firms and with southern California utilities.

The Rose Valley/Coso area was selected for this prototype study because it has many characteristics that are optimal for an SPS GRS: it offers reasonably suitable terrain and it is in a sparsely populated rural area not far from a major load center. In general, the area is typical of physical, natural and socioeconomic conditions throughout the Basin and Range Physiographic Province which encompasses much of the southwestern United States. It should be noted, however, that selection of the study site is not the result of SPS program site screening efforts, and, in fact, Rose Valley has some serious drawbacks as a potential GRS site (e.g. Rose Valley is partly within the boundaries of the China Lake Naval Weapons Center, a critical defense facility which would make it difficult to obtain the site for SPS use, as well as posing microwave-related communications interference problems). For this study, these incompatible features are ignored and the assessment proceeds as if the site was, in fact, totally suitable for an SPS GRS.

\section{DESCRIPTION OF THE PROPOSED ACTION}

The rectenna field, which is the area of the GRS where the microwave energy is collected and converted to electrical energy, would be elliptical in shape at the Rose Valley/Coso study site at $36^{\circ} \mathrm{N}$ latitude. The ellipse would have a length of $13.4 \mathrm{~km}$ north-south and a width of $10.0 \mathrm{~km}$ east-west, enclosing an area of 10,500 hectares. Surrounding the rectenna field would be a fenced buffer zone to prevent people and animals from inadvertently entering the low-intensity fringes of the microwave beam. As currently conceived, this buffer zone would be elliptical at $36^{\circ} \mathrm{N}$ latitude, with a width of one kilometer along the eastern and western edges of the rectenna field and 1.35 kilometers along the northern and southern edges.

The rectenna field would be flat or terraced to allow the end-to-end connection of rectenna panels in long, continuous rows. The rectenna would contain about 2.5 million $3 \times 10$ meter panels, with support structures consisting of steel and concrete arches with a foundation of concrete footings. An electric power collection system, including converter stations, collection/transmission stations, stepup switching stations, buses and power transmission lines, would collect dc electrical power from the rectenna field, convert it to ac power and transform it to voltages suitable for transmission. Permanent ancillary facilities for a GRS include a control center, maintenance facilities, provisions for vehicle access and parking, and security facilities. Approximately 450 workers would be required for 24 hour/365 days per year GRS operations.

\section{GRS CONSTRUCTION}

As shown in Figure S-2, GRS construction is expected to require 25 months. This includes preliminary construction activities (e.g. initial site survey and engineering and development of construction support facilities, such as roads, utilities, and worker housing), rectenna field site preparation, rectenna construction, construction of the electric power collection system, and additional construction and pre-operation activities such as construction of the control center and startup and testing activities. 


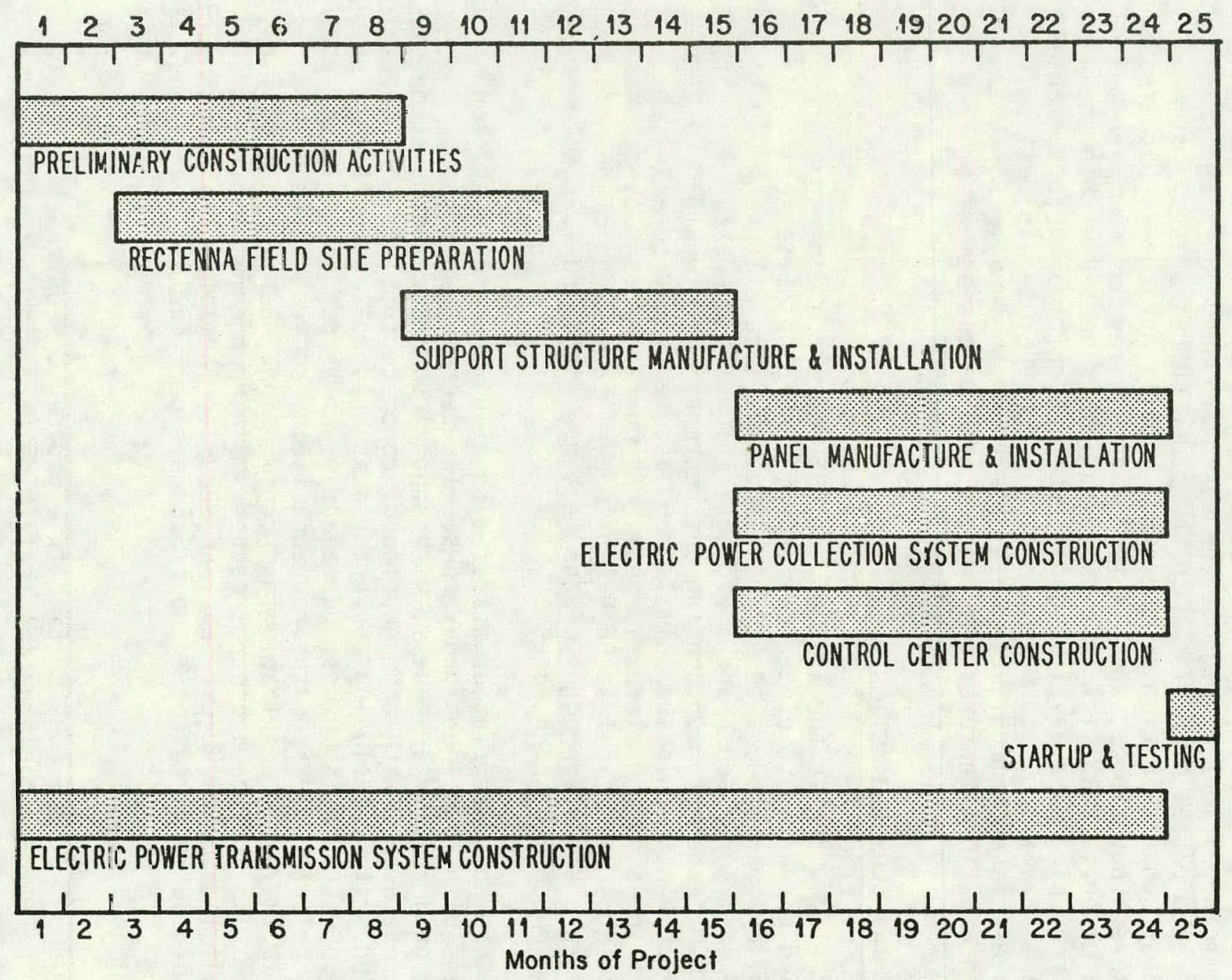

Figure S-2. SCHEDULE OF MAJOR GRS CONSTRUCTION ACTIVITIES (BASED ON GENERAL ELECTRIC, 1979) 


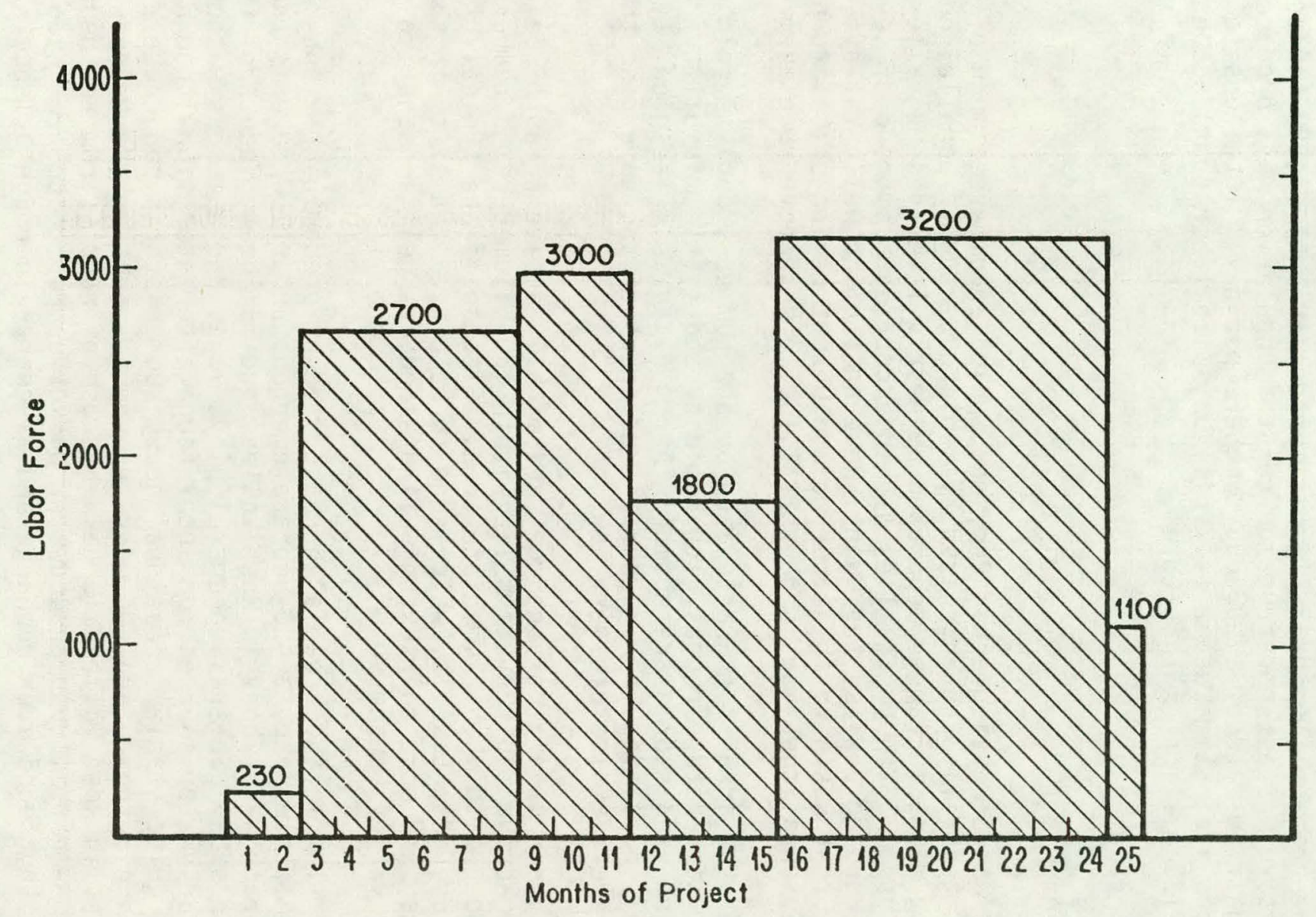

Figure $\mathrm{S}-3$. GRS CONSTRUCTION PHASE LABOR REQUIREMENTS

Source: See Appendix A. 
Figure S-3 and Table S-1 present work force and major materials requirements for GRS construction, respectively. Additional construction phase requirements include: maximum annual water demand of 2-13 million cubic meters (the wide range resulting from uncertainties in dust control and soil stabilization measures); maximum incremental electricity demand of $16 \mathrm{MW}$; and onsite fuel use of roughly 450 million liters. Materials transportation requirements will be significant, requiring over six 100-car unit trains or 2,400 truck trips per day (or some combination of the two) during Months 9-15. Rectenna field site preparation (Months $3-11$ ) will produce roughly 1,800 tonnes per day of vegetative wastes; construction-related population will produce a maximum sewage flow rate of 1,500 cubic meters per day. Total onsite construction costs are estimated at $\$ 1.7$ billion, with labor costs accounting for roughly $\$ 130$ million of this total.

\section{PRESENT ENVIRONMENT}

\section{NATURAL ENVIRONMENT}

The Basin and Range Physiographic Province, which encompasses much of the southwcst, is generally chardclerized by $i s n l a t e d$, roughly parallel northsouth trending mountain ranges separated by nearly level desert valleys. The Rose Valley/Coso GRS study site lies within a corridor composed of several north-south trending basins, the Owens, Rose and Indian Wells Valleys, which connects the Great Basin to the upper Mojave Desert region of California. Average elevation at the site is roughly 1,100 meters above sea level.

The climate of the area is characterized by hot summers, cool to cold winters, large diurnal temperature ranges, low humidity and little visibility restriction. Gusty winds and wind storms are common. Air quality is quite good, typical of the sparsely populated, nonindustrialized areas of the desert southwest; ambient noise levels also are very low.

The site lies near several of the most seismically active areas of California. Several large active fault systems lie within 150 kilometers; a number of faults are known within the immediate area. Site soils are typical of Great Basin and Mojave desert soils, which tend to be clayey and silty in the valley bottoms, and more coarse and well drained, as well as sandy to stoney, away from the valley bottoms.

Surface water flow in the area is characterized by predominantly ephemeral stream flow. Little Lake, a 400-hectare emergent underflow lake is the only perennial surface water body in Rose Valley, and is located south of the rectenna field site. Several ephemeral playa lakes and numerous washes become temporary water sources for local fauna after storms. Although soils are generally quite stable, occasional heavy summer storms can cause a tair amount of channel erosion and sediment transport. Substantial groundwater resources exist in Rose Valley, largely because of runoff from the nearby Sierra Nevada. The Valley's groundwater basins appear to be near hydologic equilibrium with groundwater recharge and discharge in rough balance.

The study site is in an area transitional between the Mojave Desert ecosystems to the south and the Great Basin ecosystems to the north. Thus the study area exhibits a complex vegetative pattern with a floral diversity greater than would be expected in areas exclusively within either the Mojave or Great Basin. The common Creosote Bush Scrub Community and Shadscale Scrub Community 
TABLE S-1 MAJOR MATERIALS REQUIREMENTS OF GRS CONSTRUCTION

Aggregates and Ballast
Cement
Concrete
Steel
Aluminum
Plastic
Ceramic
Diodes

$11,000,000$ tonnes
$1,400,000$ tonnes
$6,500,000$ cubic yards
$1,700,000$ tonnes
170,000 tonnes
16,000 tonnes
6,000 tonnes
7.5 billion

Sources': General Electric (1979), Boeing (1978), Los Angeles Department of Water and Power (1975, 1976). 
are the predominant vegetative types. Although no federally listed rare, threatened or endangered plant species are found in Rose Valley, several local plants (e.g. desert cordgrass, the white canby poppy) are listed as very rare or rare by the California Native Plant Society.

The desert ecosystems of the site supports a relatively abundant fauna, although there is not a great diversity of species present. Of note is that 68 migrant bird species were found in the area during recent field surveys. Over twenty of these are migratory water fowl, for whom Little Lake and the ephemeral playas of Rose Valley are important habitats along their migration route. None of the animal species known or expected in the area is on federal or state listings of threatened or endangered species, although an abundant population of the Mohave ground squirrel (listed as rare by the California Fish and Game Commission) exists throughout Rose Valley.

\section{HUMAN ENVIRONMENT}

In general, land use in the study vicinity, like that throughout rural portions of the Basin and Range Province, is not notably intensive (less than 30 percent on average), or extensive (approximately 15 percent of the larld has no designated use). In accordance with current policy of most federal agencies (which control over 90 percent of the general area), multiple uses of land exist over approximately 35 percent of the area. The most common coexisting land uses are recreation, natural resource management, grazing and mining activities. Urbanized land uses within the region account for less than 0.4 percent of the total land area. Approximately 60 percent of the study site is administered by the Bureau of Land Management (BLM); the Naval Weapons Center administers another 35 percent, the State of California 2 percent, with the remaining 3 percent in private ownership.

The 2,250 square kilometer area that would be expected to experience socioeconomic impacts as a result of GRS develupinent, had a total population of over 27,000 in 1977. The communities of Ridgecrest and China Lake contained over 21,000 of this total, with the remainder distributed in rural areas. U.S. Route 395 is the only north-south artery in the arca, with usage currently well below capacity.

Resource industries, government (partly because of employment at the Naval Weapons Center) and trade are the dominant employment sectors in the area. Average income throughout the area is sullewhat lower than for California as a whole. As might be expected given the reginn's sparse population and nonextensive or intensive land use patterns, local governments' tax and revenue base are quite small.

Because of the long-term human occupancy of the area (over 10,000 years) and environmental conditions conducive to preservation of evidence of this occupancy, Rose Valley possesses archaeological/cultural resources of constderable significance and sensitivity. A recent cultural resources survey of the area revealed a large number of archaeological sites. A 370-hectare portion of southern Rose Valley has been nominated for the National Register of Historic Places as the Fossil Falls Archaeological District. In terms of aesthetic resources, the study area as a whole is generally lacking in outstanding or dramatic visual features. 
IMPACTS

Table S-2 summarizes, by major technical area, the environinental impacts of GRS development on the Rose Valley/Coso study area. Impacts of both GRS construction and operations are presented; possible mitigation measures are identified, where applicable.

\section{CRITICAL PARAMETERS}

Foremost among the critical project parameters revealed in this prototype assessment is the sheer size (roughly 11,000 hectares) and intensivity of use of the contiguous land area required by an SPS GRS. This land area must be totally committed to the project, completely displacing existing land uses and totally modifying the existing natural environment. At the present time it is presumed that the land occupied by the rectenna panels could not be used for other purposes. This presumption is based on current concerns about potential microwave biologic effects at rectenna sites, a subject not included in this report. Although microwave power densities would be much lower under rectenna panels than directly above them, adequate data are not yet available to confidently assess whether very low intensity microwave effects might occur under rectennas. It has been suggested that innovative rectenna designs might be possible which would permit multiple land use under rectennas, such as intensive crop agriculture, biomass production and aquaculture at offshore rectenna sites. Since such ideas remain speculative, it is current policy to presume that rectennas would require dedicated land use. Further, SPS microwave transmission and reception operating constraints would not permit flexibility in siting individual rectenna structures after the coordinates of the rectenna field boundaries are established. Thus the ability to avoid specific sensitive areas (e.g. a unique biological habitat, an important archaeological site) by reconfiguring project elements is greatly diminished.

The Rose Valley/Coso prototype study site also reveals the difficulty in finding sites suitable (e.g. size, topography) for SPS that do not involve conflicts between SPS and other societal needs and values. In Rose Valley there are potential conflicts with significant archaeological resources, an extant geothermal resource, and with national defense uses (i.e. the Naval Weapons Center). Numerous large unpopulated areas in the southwest are in use (or proposed) for defense purposes. For example, of the 6.5 million hectares comprising the California Desert Conservation Area, over 1.0 million hectares or 15 percenil of the total area are withdrawn for use by the Department of Defense.

A critical project characteristic is that the entire rectenna site must be completely cleared, graded and compacted, thereby totally destroying the existing flora and fauna over a 100 square-kilometer area. It is problemmatic whether anything resembling the preexisting interrelated flora and fauna could be reestablished after lRS construction is completed. The reasons for this are the altered environmental conditions of the site and perhaps also the operational requirements of the GRS itself.

There are critical uncertainties, that will require further research, relating to the issue of reestablishment of the naturally occurring ecosystems of the the GRS site. Primary among these are questions relating to the microclimatic conditions (temperature, humidity, wind, precipitation) in the first few centimeters above the ground surface between the rectenna panels. Minor climatic 
Table S-2. " "SUMMArY OF" GŔS CONSTRUCTION AND OPERATIONS PHASES ENVIRONMENTAL IMPACTS

\begin{tabular}{|c|c|c|c|}
\hline TECHNICN AREA & GRS CONSTRJCTION & GRS OPERATIOMS & MITIGATION \\
\hline $\begin{array}{l}\text { Air Quality/Clima- } \\
\text { tology }\end{array}$ & $\begin{array}{l}\text { - Probable standards } \\
\text { violation for nitrogen } \\
\text { oxides, particuiates } \\
\text { and hydrocarbons } \\
\text { - No climatic impacts }\end{array}$ & $\begin{array}{l}\text { - No significant air quali- } \\
\text { ty impacts } \\
\text { - Unknown, but possibly } \\
\text { significant microclimatic } \\
\text { effects at/near ground } \\
\text { surface }\end{array}$ & $\begin{array}{l}\text { - Adequate dust suppression program } \\
\text { during construction would miti- } \\
\text { gate particulates impacts } \\
\text { - Extending construction schedule } \\
\text { would reduce emission peaks for } \\
\text { hycrocarbons and nitrogen oxides } \\
\text { - Perding further research, project } \\
\text { mocifications might be needed for } \\
\text { grcund surface microclimate im- } \\
\text { pacts }\end{array}$ \\
\hline Noise & $\begin{array}{l}\text { - Substantially elevated } \\
\text { noise levels, but very } \\
\text { few human no: se recep- } \\
\text { tors in the area } \\
\text { - Possible impacts on } \\
\text { noise sensitive species }\end{array}$ & - No significant impact & $\begin{array}{l}\text { - Improved roise control technology } \\
\text { by GRS implementation time frame } \\
\text { for vehicles, equipment and pro- } \\
\text { cesses (e.g. arch and panel fabri- } \\
\text { ca:ion) would mitigate construc- } \\
\text { tion phase impacts } \\
\text { - Du-ing construction, noise sensi- } \\
\text { tive habitats should be avoided } \\
\text { to maximun extent possible during } \\
\text { brzeding/nesting seasons }\end{array}$ \\
\hline \begin{tabular}{l} 
Geology/Soils \\
\hdashline$\quad \therefore \quad$ \\
\hdashline$\quad \therefore \quad$
\end{tabular} & $\begin{array}{l}\text { - Geologic impacts less } \\
\text { important than ge slogic } \\
\text { constraints } \\
\text { - Study area very a ative } \\
\text { seismically, but within } \\
\text { nomal range far south- } \\
\text { ern Cal iformia } \\
\text { - Soils impacts signifi- } \\
\text { cant: large disturbed } \\
\text { area; compaction; wind/ } \\
\text { water erosicn } \\
\text { - Soils constrai its: di- } \\
\text { versity of soils types } \\
\text { implies variability in } \\
\text { engineering properties } \\
\text { (e.g. shrink/swell po- } \\
\text { tential comrosivity } \\
\text { to metals/concrete) }\end{array}$ & $\begin{array}{l}\text { - Seismicity has potential } \\
\text { for facility destruction } \\
\text { or loss of efficiency } \\
\text { (alignment. vs. satellite) } \\
\text { - Soil product ivity impact- } \\
\text { ed for project life: de- } \\
\text { pends on extent and de- } \\
\text { gree of construction } \\
\text { phase and ongoing oper- } \\
\text { ations disturbance } \\
\end{array}$ & $\begin{array}{l}\text { - Thsrough seismic and soils studies } \\
\text { required as part of site-specific } \\
\text { engineering } \\
\text { - Careful soil stabilization/drain- } \\
\text { age/erosion control programs re- } \\
\text { quired } \\
\therefore\end{array}$ \\
\hline
\end{tabular}


Table S-2 (cont inued)

\begin{tabular}{|c|c|c|c|}
\hline TECHNICAL AREA & GRS CONSTRUCTION & GRS OPERATIONS & MITIGATION \\
\hline $\begin{array}{l}\text { Hydrol ogy/Water } \\
\text { Quality }\end{array}$ & $\begin{array}{l}\text { - Project requirements } \\
2-13 \text { million cubic me- } \\
\text { ters over } 2 \text {-yr period } \\
\text { (depends on dust sup- } \\
\text { pression methods used) } \\
\text { - Meeting project needs } \\
\text { from groundwater would } \\
\text { lover water table } 0.2 \\
\text { to } 1.5 \text { meters/year; } \\
\text { would reduce underflow } \\
\text { to adjoining valley; } \\
\text { could lower water level } \\
\text { in nearby lake; might } \\
\text { cortaminate usable } \\
\text { water through hydraulic } \\
\text { cornect ion with unus- } \\
\text { able groundwater } \\
\end{array}$ & $\begin{array}{l}\text { - Project requirements mi- } \\
\text { nor unless major revege- } \\
\text { tation program under- } \\
\text { taken. Revegetation } \\
\text { could require } 27 \text { million } \\
\text { cubic meters/year for } \\
3 \text { years or more, which } \\
\text { could cause water table } \\
\text { drawdown }\end{array}$ & $\begin{array}{l}\text { - Careful soil stabilization/drain- } \\
\text { age/erosion control program re- } \\
\text { quired } \\
\text { - Groundwater withdrawal impacts } \\
\text { mitigable by import ing water from } \\
\text { outside study area } \\
\text { - Proper sewage control program ne- } \\
\text { cessary during construction to } \\
\text { prevent water quality degradation } \\
\end{array}$ \\
\hline Flora & $\begin{array}{l}\text { - Land disturbance would } \\
\text { completely modify } \\
\text { site's floral communi- } \\
\text { ties } \\
\text { - Possible indirect im- } \\
\text { pacts on flora from } \\
\text { hydrologic changes, air } \\
\text { and water pollutants } \\
\text { and personnel activi- } \\
\text { ties } \\
\text { - No endangered species } \\
\text { present at Rose Valley/ } \\
\text { Coso; one rare species } \\
\text { present }\end{array}$ & $\begin{array}{l}\text { - Impacts similar to con- } \\
\text { struction phase } \\
\text { - Microcl imate changes at } \\
\text { ground surface a key } \\
\text { issue for severity/miti- } \\
\text { gability of floral im- } \\
\text { pacts }\end{array}$ & $\begin{array}{l}\text { - Reestablishment of preexisting } \\
\text { flora problematic; major and } \\
\text { difficult revegetation program } \\
\text { required } \\
\text { - Careful placement of ancillary } \\
\text { facilities necessary to minimize } \\
\text { impacts on sensitive habitats } \\
\text { - Careful planning, design and } \\
\text { construction/operations practices } \\
\text { necessary to minimize indirect } \\
\text { impacts (e.g. water quality de- } \\
\text { gradation) }\end{array}$ \\
\hline
\end{tabular}


Table S-2 (continued)

\begin{tabular}{|c|c|c|c|}
\hline TECHNICAL AREA & GRS CONSTRUSTION & GRS OPERATIONS & MITIGATION \\
\hline Faunà & $\begin{array}{l}\text { - Land disturbance would } \\
\text { completely nodify site } \\
\text { faunal communities } \\
\text { - Fossible indirect im- } \\
\text { pacts on fauna from } \\
\text { hydrologic changes, air } \\
\text { and water pollutants, } \\
\text { personnel activities } \\
\text { and loss of feeding } \\
\text { areas for nearby fauna } \\
\text { - Surface water sources } \\
\text { for migratory water and } \\
\text { land birds wolld be } \\
\text { lost (playas) and jeo- } \\
\text { pardized (Little Lake) } \\
\text { One protected species } \\
\text { (Mohave ground squir- } \\
\text { rel) found in Rose } \\
\text { Valley } \\
\end{array}$ & $\begin{array}{l}\text { - Impacts similar to con- } \\
\text { struction phase } \\
\text { - Impacts closely related } \\
\text { to flora impacts } \\
\text { - Microcl imate changes at } \\
\text { ground surface a key } \\
\text { issue for severity/miti- } \\
\text { gability of fauna impacts } \\
\end{array}$ & 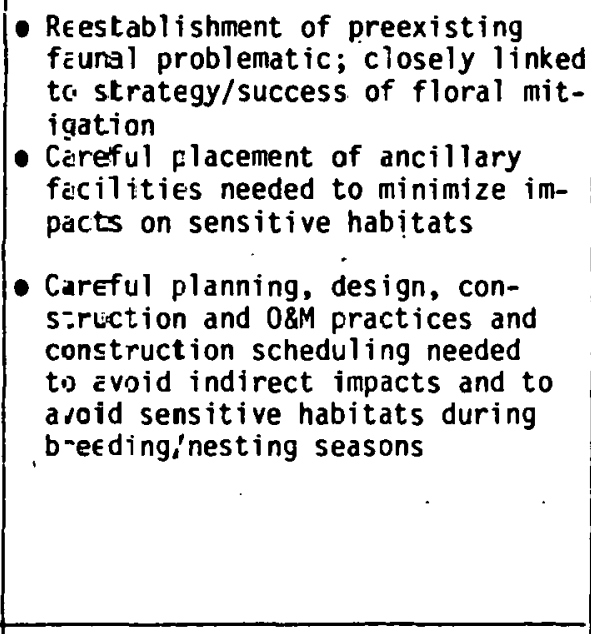 \\
\hline Land Use & $\begin{array}{l}\text { - Total displacement of } \\
\text { existing site uses } \\
\text { (e.g. farming. grazing, } \\
\text { recreation) } \\
\text { - Minor loss of mineral } \\
\text { resources (cinder, pu- } \\
\text { mice) } \\
\text { - Minor indirect (growth- } \\
\text { related) inpats } \\
\text { - Potent ial land acquisi- } \\
\text { tion/use conflicts with } \\
\text { Navy (China Lake NWC), } \\
\text { energy (geothermal), } \\
\text { wilderness. archae- } \\
\text { ological resaurces, } \\
\text { Native: Anerican use/ } \\
\text { access to culturail/ } \\
\text { religious sites }\end{array}$ & $\begin{array}{l}\text { - Same as construction } \\
\text { phase }\end{array}$ & $\begin{array}{l}\text { - Major imoacts not initigable } \\
\text { - Land use current ly presumed to } \\
\text { be dedicated solely to SPS } \\
\text { recienna. This may change, } \\
\text { depending on results of microwave } \\
\text { tiologic effects research and } \\
\text { essessment (not addressed in this } \\
\text { report) }\end{array}$ \\
\hline
\end{tabular}


Table S-2 (con:inued)

\begin{tabular}{|c|c|c|c|}
\hline TECHNICAL AREA & GRS CONSTRUCTION & GRS OPERATIONS & MITIGATION \\
\hline Socioeconomics & $\begin{array}{l}\text { - Rose Valley/Coso siting } \\
\text { would create peak enl- } \\
\text { ployment of } 3,800 \text { jobs } \\
\text { (direct \& indirect) in } \\
\text { area } \\
\text { - Population inmigration } \\
\text { (3,900) would strain } \\
\text { local infrastructure } \\
\text { somewhat (e.g. housing, } \\
\text { government services); } \\
\\
\text { - Relatively small in- } \\
\text { creased government } \\
\text { costs in Rose Valley/ } \\
\text { Coso; relatively smal1 } \\
\text { increase in government } \\
\text { revenues (if GRS pub- } \\
\text { licly owned) } \\
\end{array}$ & $\begin{array}{l}\text { - Rose Valley/Coso siting } \\
\text { would create } 800 \text { new jobs } \\
\text { (direct \& indirect) in } \\
\text { area } \\
\text { - Permanent population } \\
\text { growth }(2,300) \text { absorbable } \\
\text { with relatively minor im- } \\
\text { pacts; impacts would be } \\
\text { more severe in more re- } \\
\text { mote area } \\
\text { - Relatively small increas- } \\
\text { ed governmental costs; } \\
\text { relatively small tax base } \\
\text { growth (if GRS publicly } \\
\text { owned) }\end{array}$ & $\begin{array}{l}\text { - Provision of sizable onsite con- } \\
\text { struction personnel housing facil- } \\
\text { ities a key mitigation element } \\
\text { - Extending GRS construction sche- } \\
\text { dule would reduce socioeconomic } \\
\text { impact peak } \\
\text { - Careful advance planning needed } \\
\text { to prevent "boomtown" growth } \\
\text { problems, particularly in areas } \\
\text { more remote than Rose Valley/Coso }\end{array}$ \\
\hline Cultural Resources & $\begin{array}{l}\text { - Total disruption of all } \\
\text { archaeological/histori- } \\
\text { cal resources within } \\
\text { rectenna field site } \\
\text { - Access to nearby cul- } \\
\text { tural sites would be } \\
\text { disrupted } \\
\end{array}$ & $\begin{array}{l}\text { - Same as construction } \\
\text { phase }\end{array}$ & $\begin{array}{l}\text { - Impacts hard to mitigate if GRS } \\
\text { site is rich in cultural re- } \\
\text { sources } \\
\text { - Salvage of resources possible } \\
\text { before construction, but would } \\
\text { be extremely expensive if signi- } \\
\text { ficant resources present } \\
\end{array}$ \\
\hline Visual Resources & $\begin{array}{l}\text { - Complete visual modi- } \\
\text { fication of site, but } \\
\text { Rose Valley/Coso not } \\
\text { high in scenic value } \\
\text { - Facility would be visi- } \\
\text { ble from air and froin } \\
\text { Sierra Nevadas } \\
\text { - Increased fugitive dust } \\
\text { would have temporary } \\
\text { visibility impact }\end{array}$ & $\begin{array}{l}\text { - Impacts, same as con- } \\
\text { struction phase except } \\
\text { that no significant dust } \\
\text { emissions expected (visi- } \\
\text { bility impact) }\end{array}$ & $\begin{array}{l}\text { - Facility should be designed (e.g. } \\
\text { painted) to maximize harmony with } \\
\text { natural surroundings }\end{array}$ \\
\hline
\end{tabular}


Tab.le S-2 (continued).

\begin{tabular}{|c|c|c|c|}
\hline TECHNICAL AREA. & GRS ZONSTRUCTION. & GRS OPERATIONS & MITIGATION. \\
\hline $\begin{array}{l}\text { Electrici=y. Sufply } \\
\text { and' Demand }\end{array}$ & $\begin{array}{l}\text { - Electrizity demand } \\
\text { estimated at } 16 \text { MW at } \\
\text { Rose Vall ley/Coso }\end{array}$ & $\begin{array}{l}\text { - Major source of baseload } \\
\text { electric power } \\
\text { - 5-GW. GRS would represent } \\
\text { about } 2.5 \text { years of pro- } \\
\text { jected Cal ifornia annual } \\
\text { Capacity growth and } \\
\text { roughly one year of pro- } \\
\text { jected growth for Hestern } \\
\text { Systens. Coordinating } \\
\text { Council (regional power } \\
\text { pool) }\end{array}$ & - None requi red \\
\hline
\end{tabular}


changes in desert environments, where biota are quite narrowly adapted to their particular ecological niches, can significantly alter species composition of flora and fauna.

Given that insolation will be altered beneath the panels; that wind patterns will be aitered by the presence of the rows of rectenna panels; that precipitation/infiltration patterns will be altered by soil disturbance and compaction, and by the drainage system that must be installed, it appears inevitable that ground surface microclimates will be different because of the rectenna's presence, although the nature of these differences is unclear.

From an operational point of view, in a desert environment it may not be desirable to reestablish flammable native vegetation within the rectenna field because of the fire risk. Also if soil stabilizing chemicals are required to control wind and water erosion, the chemicals used could affect the nature and extent of vegetative and faunal reestablishment.

The size, intensivity and inflexibility of rectenna land use requirements suggest that SPS site screening/selection activities should focus on identifying suitable potential GRS sites that are larger than the minimum GRS requirements (11,000 hectares, excluding the buffer zone). While it is not possible to identify the optimal size site (i.e. how much bigger than the minimum requirement), a larger site would preserve a measure of flexibility in rectenna field placement that would be unavailable in a site barely of sufficient siże.

Another critical parameter of GRS siting, particularly in arid desert regions, is the supply of sufficient water of adequate quality, especially during project construction. During GRS operations water requirements would be minor unless a major revegetation program is undertaken (which could require millions of cubic meters of water per year for three years or more). While GRS operational water requirements would be significantly smaller than for thermal (coal or nuclear) power plants which require large amounts of cooling water (on the order of 18-30 million cubic meters annually per 1,000 megawatts), GRS construction water demand could be significant in many areas.

The two-yeaar GRS construction schedule has a number of potentially significant impilications. These relate to socioeconomic impacts on the siting region, possible impacts on the regional availability/price of GRS construction materials such as cement, aggregate (sand and gràvel) and steel, peak construction phase impacts on air quality, water supplies and biological resources, and possible logistical problems for GRS construction itself.

The most critical element of GRS construction phàse socioeconomic impacts reilates to the level of inmigration of construction workers, (average of 2,500 , péak of 3,200 ), their dependents and secondäry emiployees associated with GRS development. The larger the existing population and employment bảse of the siting area, the fewer inmigrants would be required, the greater the cápacity of the area to absorb this growth, and consequently the less of a strain on the entire socioeconomic fabric of the area. Rapid growth in rưàl areàs can overtax the financial and service capacities of local agencies and can have adverse effects on the social fabric of small stable, homogeneous communities. The interrelationship of socioeconomic effects and the construction schedule involves the size and duration of construction phase 
inmigration. If the same total amount of labor to construct the GRS were spread out over a longer period of time, then the size of the inmigrant GRS construction work force at any one time and the associated population growth impacts would be reduced.

An extended construction period also would reduce peak air pollutant emissions by extending the same volume of emissions over a longer period of time. The same would be true for peak water demand.

The two-year construction schedule also could imply substantial logistical problems, particularly with regard to the delivery to the site of enormous quantities of construction materials during the period (Months 9-15) when rectenna support structure fabrication and installation and foundation installation are scheduled. The delivery of $10 \mathrm{million}$ tonnes of aggregate, 1.4 million tonnes of cement and 370,000 tones of steel could require 2,400 heavy truck trips per day or six 100-car unit trains per day. Even wilh d cullibillaliun or truck and rail, handling thie level of arrivals and deplarlures, as well as unloading, storing and distributing this volume of material could cause substantial problems. An extended construction periud would reduce the volume of deliveries at any one time and would reduce these problems.

GRS construction also could affect the regional availability/price of construction materials such as cement, aggregates (sand and gravel) and steel. For example, construction of an SPS GRS would require 11 percent of California's total 1978 production of aggregate, 17 percent of 1978 California production of cement and over 80 percent of California's 1978 steel production (and over one percent of total U.S. production). An extended GRS construction schedule would moderate these impacts somewhat by spreading the materials requirements over a longer period of time.

Another key project parameter is whether the GRS is publicly uwned or privately owned. If the facility is publicly owned then relatively minor tax revenue benefits would accrue to local jurisdictions, largely because public facilities do not produce property tax revenues. If the GRS is jublicly owned, then the fiscal burdens of GRS development (e.g. infrastructure improvements) would be imposed on the local area without the tax base increases to compensate for the increased burden (although the area conceivably could be designated as a "federal impact area" and thereby become eligible for federal fiscal assistance). Private ownership, by contrast, would significantly augment the local tax base.

Because of the extraordinarily high number of identical components in the rectenna field, the design and propertles of the parlel cuilpunents can have significant environmental implications. Some observations on these factors include:

- The rectenna panels should be as light and open as possible to allow both sunlight and precipitation to reach the ground surface with a nearly natural distribution.

- Panel and diode/dipole design must take into account certain natural phenomena such as snow, ice, moisture, GRS site, soil types (e.g. alkaline desert soils) and dust storms, as well as possible problems stemming from the attractiveness of the panels, as resting areas for birds and rodents. 
- Rectenna design should take into account possible microclimatic effects near the ground surface, as well as seismic factors (particularly in earthquake prone areas).

- The rectenna design process should consider ways to minimize the use of materials, particularly concrete and steel; this could reduce water and electricity needs, transportation requirements, air pollution and solid waste production. 
THIS PAGE

\section{WAS INTENTIONALLY \\ LEFT BLANK}

$5-18$ 


\subsection{INTRODUCTION}

\subsection{THE SATELLITE POWER SYSTEM CONCEPT DEVELOPMENT AND EVALUATION PROGRAM}

The Department of Energy and the National Aeronautics and Space Administration are investigating a potential new source of energy called the Satellite Power System (SPS). The SPS concept involves placing a satellite equipped with large solar cell arrays in orbit around the earth. The energy collected by the satellite is converted to microwaves and then beamed to a Ground Receiving Station (GRS), which is composed of a receiving antenna (rectenna) and electric power collection and transmission facilities, a control center, etc. Each GRS would provide 5,000 megawatts (five gigawatts) of electrical power to the utility grid.

This report is a prototype environmental assessment of an SPS Ground Receiving Station (GRS). (Throughout the report the term Ground Receiving Station or GRS is used to describe the facility in order to distinguish between the rectenna (receiving antenna) which actually receives and rectifies the microwave energy, and the overall facility which includes power converters, support facilities, access roads, a buffer zone, etc. as well as the rectenna itself.) This study is part of the ongoing DOE/NASA SPS Concept Development and Evaluation Program (CDEP). The objective of this program "is to achieve by the end of 1980 an initial understanding of the technical feasibility, economic practicability, and the social and environmental acceptability of the SPS concept so that recommendations concerning program continuation can be made" (DOE, 1978).

The SPS CDEP includes four major study areas:

- System Definition

- Environmental Assessment

- Societal Assessment

- Comparative Assessment of Alternative Energy Systems.

This prototype environmental assessment comprises a part of both the Environmental Assessment and Societal Assessment study.tasks. This report represents two separate studies combined into one report: one addressing impacts on the natural environment (part of the Environmental Assessment task), the other addressing impact.s on the human environment (part of the Societal Assessment task). One combined report has been prepared (with the Description of the Proposed Action common to both studies), because comprehens ive environmental assessments address the interrelated impacts of a project on both the natural and human environments in an integrated fashion. The Natural Environment study was prepared under contract to Argonne National Laboratory. The description of baseline natural environment conditions is found in Sections 3.1 3.9 and natural environment impacts are described in Sections 4.2-4.7. The Human Environment study was prepared under contract to PRC Energy Analysis Company; relevant baseline conditions are described in Sections 3.10-3.14 and impacts are assessed in Sections 4.8-4.12. Chapter 5 summarizes GRS impacts on both the natural and human environment. The chapter on Critical Project Parameters (Chapter 6 ) relates to both the natural and human environment. GRS construction data is summarized in Chapter 2 and is elaborated in Appendix A. 


\subsection{OBJECTIVES}

The objectives of this study are:

- To develop a comprehensive prototype assessment of the non-microwave related (e.g. microwave health and safety and communications impacts) impacts on the natural and human environment of the Reference System SPS rectenna facility or Ground Receiving Station (GRS).

- To assess GRS construction and operations environmental impacts in the context of actual baseline data for a site in the California desert about 250 kilometers north of Los Angeles referred to as Rose Valley (specific GRS site)/Coso (general area). (See Figure 1.4-1 for a map showing study area location.)

- To identify critical engineering design and construction parameters that are most significant in terms of both the natural and human environment.

\subsection{SCOPE}

This prototype environmental study includes each of the basic elements cormonly found in a formal Environmental Statement: a description of the proposed project, a description of the present environment of the siting area, an assessment of impacts and identification of possible mitigation measures for the construction and operation of a GRS. Each of the following technical areas is addressed:

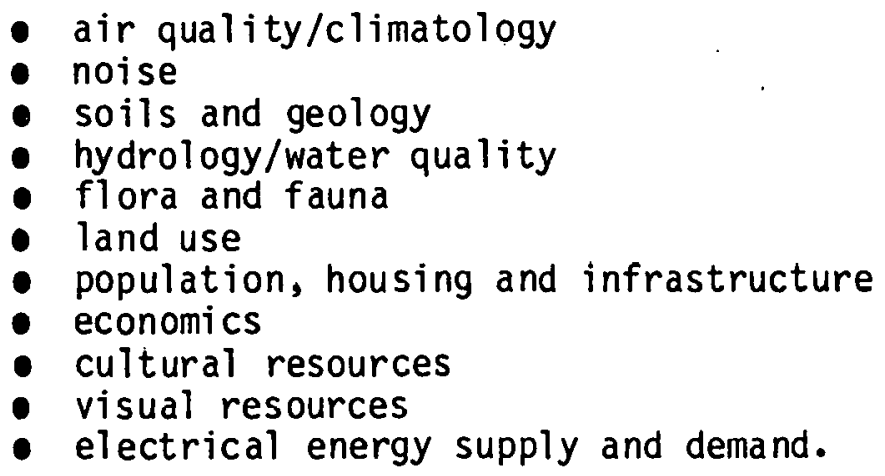

This study is not a formal Environmental Statement (ES) prepared in compliance with the National Environmental Policy Act (NEPA); rather it is a prototype environmental assessment. It does not include the traditional ES analysis of alternatives (i.e. in analyzing the impacts of a coal-fired power plant, one might evaluate alternative types of power plants, such as oil or nuclear, as well as considering alternative sites and the possibility of developing no power plant at ail). Such an analysis is not germane here since we are dealing with both a hypothetical project and a hypothetical site. A discussion of critical project parameters, which identifies the most environmentally significant aspects of GRS development, replaces the traditional alternatives analysis. Formal Environmental Statements will be required if and when formal specific GRS siting proposals are developed.

The scope of this prototype assessment is further clarified in the following paragraphs. 


\subsubsection{ADJACENT DEVELOPMENT}

It has been suggested that because of the availability of a large power source, certain energy-intensive industries may be located close to GRS sites. Because there has been no useful definition of the type of development that would locate near a GRS, and because the primary study objective is to assess the reference design GRS facility, no assessment of adjacent development is included in this study.

\subsubsection{CONCURRENT USE OF THE GRS SITE}

There has been some consideration of the possible uses of the GRS site for various agricultural purposes, but there exists no definitive or clear treatement of such concurrent use. Again because our objective is to assess the reference design GRS and al so because the economic impact of such concurrent use would be minor compared with the economic investment and ongoing value of the GRS as a source of electrical power, the potential for concurrent use of the GRS site is not assessed in this study.

\subsubsection{ANCILLARY ENVIRONMENTAL IMPACTS}

GRS development is expected to require additional construction beyond developing the rectenna and associated on-site support facilities, e.g. access roads and a rail spur. No independent environmental assessment of these ancillary activities is provided unless: they substantially affect peak impacts (e.g. employment, pollutant emissions or water requirements of a scale approaching that of GRS construction itself); or the activities would occur within the boundaries of the

- GRS site itself.

1.3.4 CLIMATOLOGICAL, HYDROLOGIC, SEISMIC AND OTHER GEOLOGICAL CONSTRAINTS

The impact of a project on its environment is not always clearly separable from the impact of the environment on the project. Environmental factors such as seismic activity in the GRS site vicinity can more usefully be considered as design constraints than as environmental impacts (i.e. the GRS will not change local seismicity), and as such are outside the main thrust of this study. The section of the report describing the present environment of the Coso area, however, describes basel ine geologic, hydrologic and climatological conditions and brief discussions are provided of the implications of these conditions for GRS development.

1.3.5 PHYSICAL AND TEMPORAL BOUNDARIES

The physical boundaries of the impact assessment are the same as those included in a recent Environmental Statement for a proposed geothermal leasing program in the Coso area (U.S. Department of Interior, Bureau of Land Management, 1980), which provides the data base for this study. In many cases (e.g. biology, hydrology) the study boundary is the GRS site and its immediate vicinity; for socioeconomic issues, by contrast, the study area comprises roughly 8,000 square kilometers surrounding the GRS study site. In temporal terms, 
the impact assessment is based on the most recent available baseline data for the Coso area and assumes hypothetically that the GRS was planned for construction at some point in the next several years. No attempt is made to project impacts into an as yet undefined future time frame when actual GRS siting in the California desert might occur.

\subsubsection{POWER TRANSMISSION AND UTILITY INTEGRATION}

The impacts of transmission lines needed to reach utility interties from a GRS in the Coso area are treated briefly and generically in Section 4.13. No discussion is presented of problems of intertie expansion or utility integration.

\subsection{CONSTRAINTS}

\subsubsection{GRS DESCRIPTIVE DATA}

Environmental assessments require a reasonably detalled descripliun ur lhe proposed project's environmentally salient characteristics (e.g. project features that generate air emissions, land surface disturbance, water consumption, waste production, labor force requirements). At lhe outset of this study the intention was to derive the necessary project data from the SPS Reference System Report (DOE and NASA, 1978), and other SPS literature, with additional input from NASA, Boeing and Rockwell personnel as needed. However, it became evident early in the study that this approach would not yield the required data because: 1) the SPS concept definition work had not addressed GRS construction in sufficient detail for prototype environmental assessment purposes, and 2) the kinds of environmentally salient data needed would properly be developed by construction specialists, rather than the aerospace experts involved in the NASA and contractor Systems Definition studies.

In view of these difficulties a second approach was taken to developing the needed project description. This approach is described below.

The project description is primarily based on the Boeing rectenna design, as presented and analyzed in the General Electric rectenna construction analys is (General Electric, 1979). However, information concerning the GRS, as well as the rectenna itself, was also obtained from both Rockwell and Boeing SPS definition documents. This approach was selected (in consultation with NASAHeadquarters) for two reasons: (1) the Johnson Space Center, General Electric and Boeing were presently engaged in, and were familiar with, the most current concepts in rectenna research, while Rockwell had al ready completed the ir rectenna studies; (2) the Boeing and General Electric documents contained - more of the kinds of data needed for the prototype environmental assessment, particularly for the rectenna portion of the Ground Receiving Station.

While the approach outlined above provided much of the basic information needed for the project description, there remained many areas for which data were unavailable, including:

- equipment and vehicle requirements, and their fuel consumption;

- water requirements;

- electricity requirements; 
- the amounts and types of solid waste that would be producea;

- the means of transporting materials to the site;

- the labor and material requirements for construction of ancillary facilities such as roads, rail spurs, temporary or permanent buildings, fences, transmission lines and busses, etc.

The data which were unavailable from SPS literature and personnel were obtained from several other sources: (1) Environmental Impact Statements (EISs) for large western energy projects (e.g., San Joaquin Nuclear Project, a 3,000 MW coal-fired power plant); (2) discussions with major southern Cal ifornia utilities (i.e., Southern California Edison and the City of Los Angeles Department of Water and Power); (3) discussions with major construction and engineering firms; and (3) engineering hanbdbooks and other relevant reference documents.

Essentially, the following approach was taken. To obtain estimation factors to use in extrapolating from other large energy projects to the GRS project, EISs and where available, engineering feasibility studies were examined first. To supplement and clarify this data, discussions then were held with utilities who sponsored the above mentioned energy projects (e.g. SCE and LADWP). Engineering handbooks and federal (e.g Nuclear Regulatory Commission) studies of the construction of coal plants also were exmained both to fill data gaps and to provide a check on some of the data from the project-specific documents noted above. Finally, discussions were held with major engineering and construction firm personnel to fill some remaining gaps and to review estimates and estimation approaches that had been used for their appropriateness, timeliness (Were there more current data/approaches to use?), etc.

The very general estimates and extrapolations developed through the process described above were then combined with the available SPS literature and input from NASA personnel and contractors. This enabled the development of a project description which contained reasonable estimates of the data needed for a prototype environmental assessment of GRS siting and construction. No attempt was made to be exhaustive and comprehensive in terms of each individual construction task, resource requirements, equipment and labor force, etc; rather the focus was on identifying major tasks and requirements.

\subsubsection{THE ROSE VALLEY/COSO SITE}

The Rose Valley/Coso area was selected for this prototype environmental assessment because it has many characteristics that are optimal for an SPS GRS: it offers terrain reasonably suitable for the GRS and it is in a sparsely populated rural area not far from a major load center. Figure 1.4-1 shows the location of the hypothetical GRS site; Figure 1.4-2 shows how the rectenna would be placed within the site; Figure 1.4-3 is a photograph of a typical Rose Valley landscape.

In general, the area is typical of physical, natural and socioeconomic conditions found throughout the Basin and Range Physiographic Province which encompasses much of the southwestern United States (see Figure 3.1-1). With relatively few exceptions, this is true for climate, geology, soils, hydrology, vegetation and wildlife, land use and cultural resources. (The Present 
P

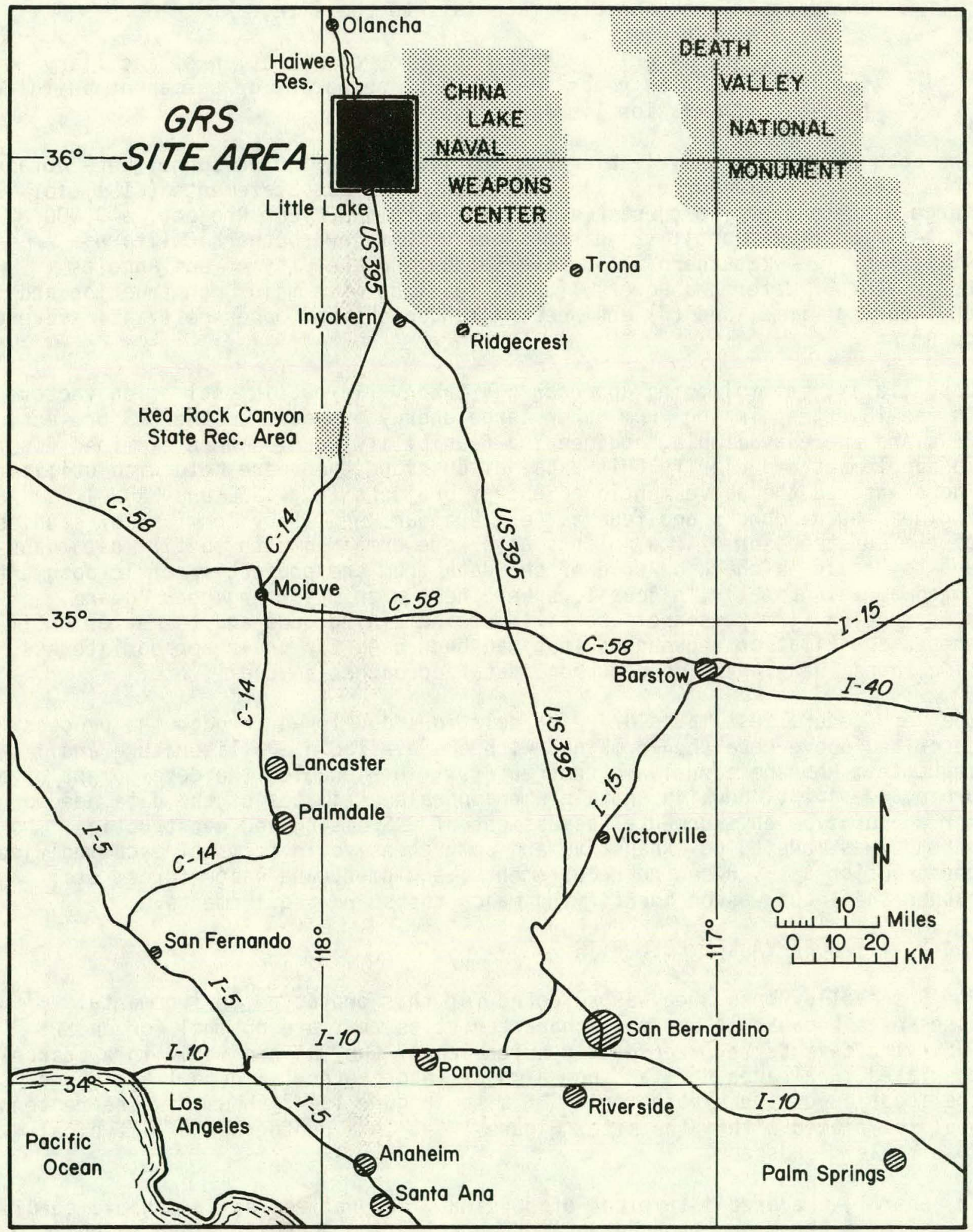

Figure 1.4-1. LOCATION OF GRS STUDY AREA 


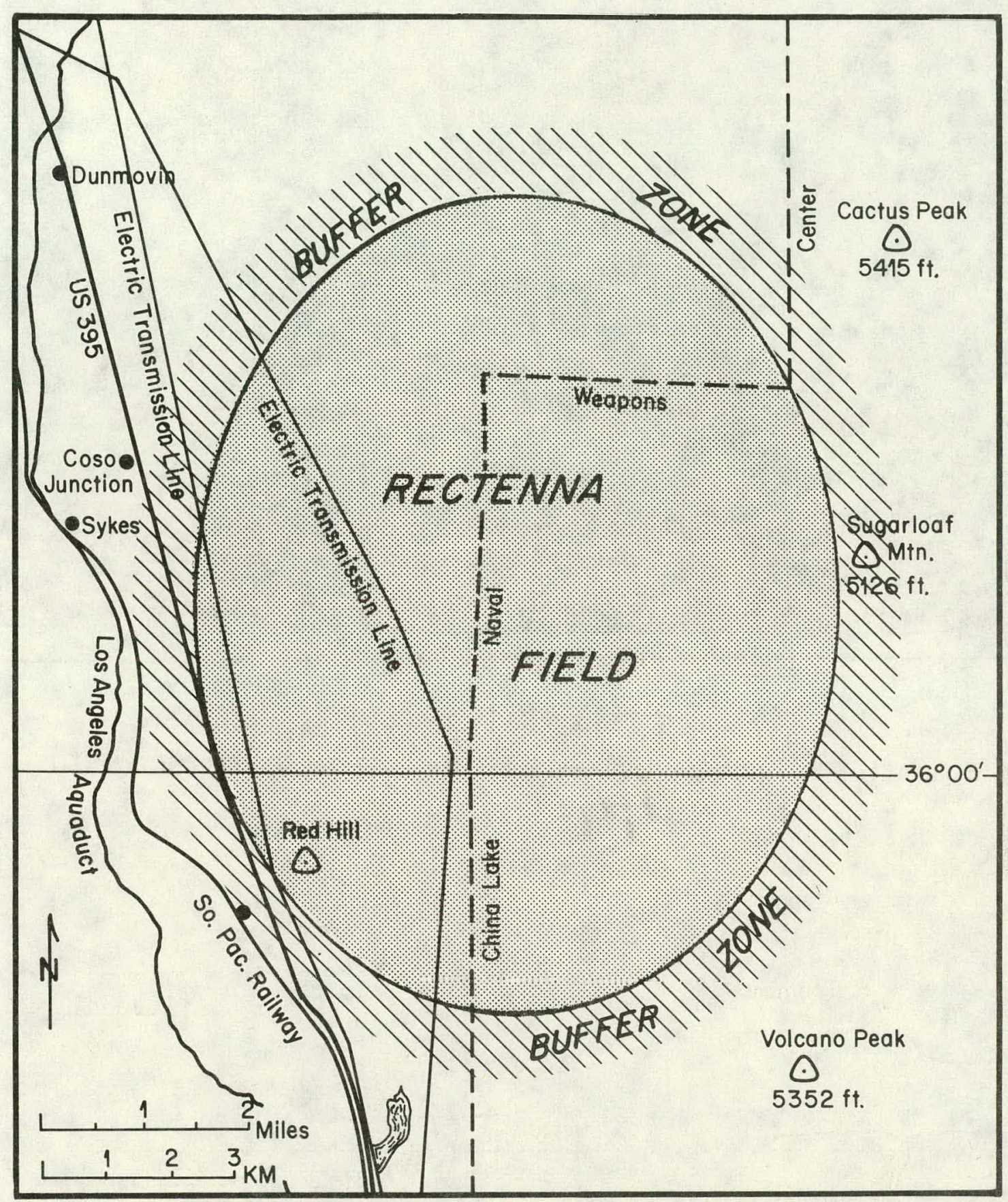

Figure 1.4-2. RECTENNA PLACEMENT WITHIN ROSE VALLEY 


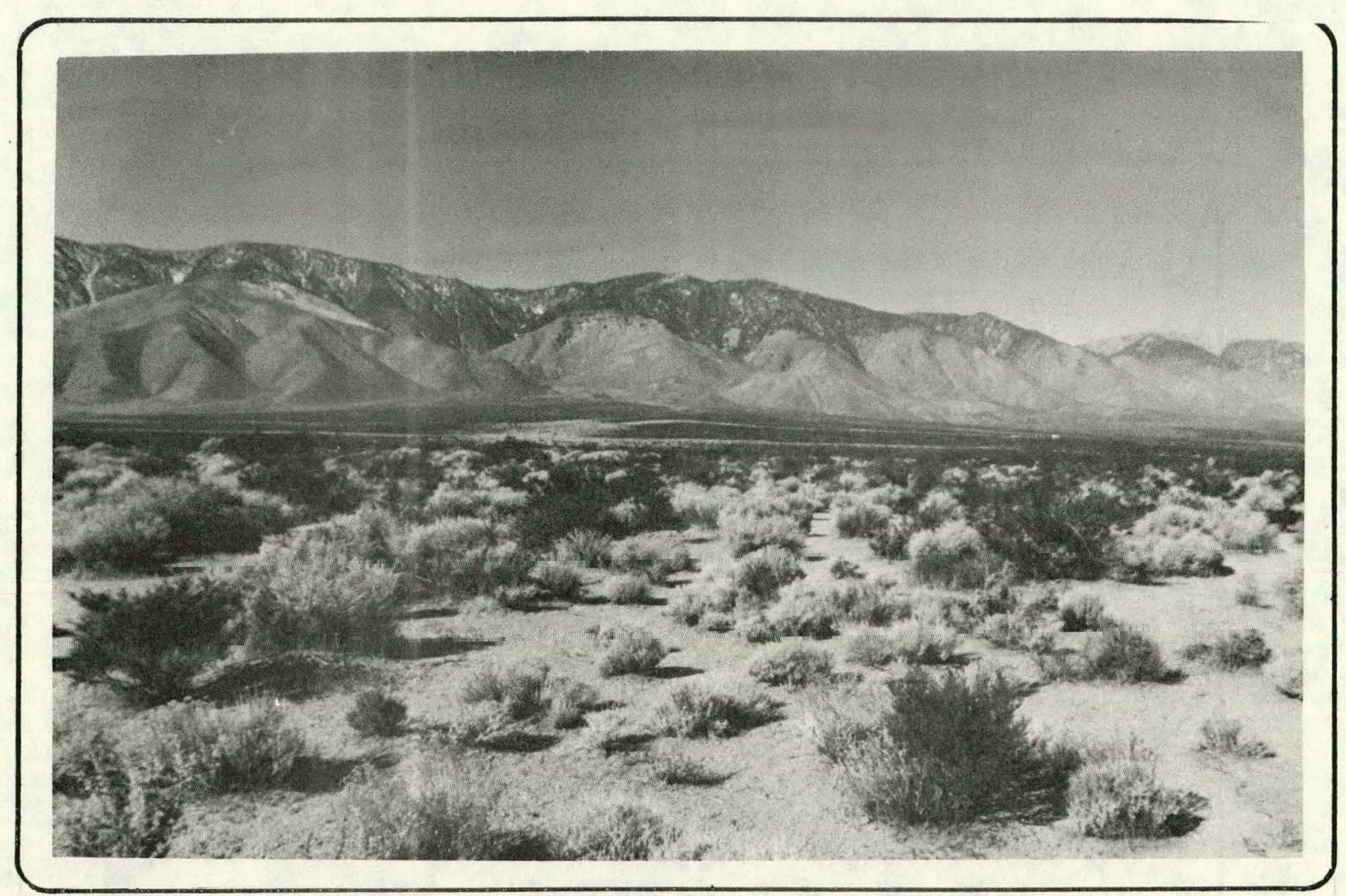

Figure 1.4-3. TYPICAL LANDSCAPE WITHIN ROSE VALLEY GRS STUDY SITE 
Environment section, Chapter 3 of this report, indicates in more specific terms the ways in which the study area is representative or unique relative to the larger region.) Thus this prototype assessment can illustrate the impacts associated with GRS siting in general, and the southwestern desert in particular. It should be noted that selection of the study site is not the result of SPS program site screening activities. In actuality, Rose Valley has some serious drawbacks as a potential GRS site. For example, a GRS in Rose Valley would extend into mountainous terrain of the Coso Range in its northeastern portion, which could make construction prohibitively expensive; the eastern portion of Rose Valley lies within the boundaries of the China Lake Naval Weapons Center, a critical defense facility that would make it difficult to obtain Rose Valley for SPS use, as well as posing microwave-related communications interference problems as described in the SPS program literature (DOE, 1978). There al so is an extant geothermal resource, . mostly east of Rose Valley, but possibly extending into the valley. For purposes of this study, these incompatible features are ignored, and the impact assessment proceeds as if the site was, in fact, totally suitable for SPS.

As shown in Figure 1.4.2, there are a number of other man-created features of the study site that are incompat ible with GRS construction and operátion. There are two existing power transmission lines that traverse the rectenna field site. In addition, U.S. Highway 395, the Los Angeles Aqueduct and a Southern Pacific rail line are within two kilometers of the western perimeter of the rectenna, some even lying within the one kilometer GRS buffer zone. For purposes of this study, it has been assumed that these transmission lines,. highway, etc. are located a nominal 16 kilometers west of the Rose Valley GRS site rather than within two kilometers of it. Potential conflicts between GRS siting and these land uses (e.g. transmission lines, highways, military land uses and other energy resources) are not unlikely within the southwestern. U.S., as such features obviously are not at all unique to Rose Valley. Further, the requirement to consider potential relocation of highways, transmission lines, etc. in siting areas otherwise suitable for SPS also is quite possible as GRS siting proceeds.

The other primary reason for using Rose Valley/Coso for this prototype assessment is that extensive baseline studies, as well as an Environmental Statement for roughly 30,000 hectares of the Coso area were recently prepared in the context of proposed geothermal development in the area (U.S. Department of Interior, Bureau of Land Management, 1980). Thus, the voluminous data describing the site already have been gathered, compiled and analyzed, which al lows development of a prototype GRS environmental assessment in a timely and cost-effective manner. 


\subsection{DESCRIPTION OF THE PROPOSED ACTION}

\subsection{DESCRIPTION OF THE GROUND RECEIVING STATION}

In this chapter the various elements of the Ground Receiving Station (GRS) of the Satellite Power System are described, based on various SPS program documents (Boeing, 1978; DOE and NASA, 1978; General Electric, 1979; Rockwel1, 1979). The following sections describe the rectenna field, the electric power collection system, and the permanent ancillary facilities such as the control center, roads, and maintenance and security facilities.

\subsubsection{RECTENNA FIELD GENERAL DESCRIPTION}

The rectenna field is the area of the GRS where the microwave beam from the satellite is collected and converted to electrical energy. It is comprised of rectenna panels (which contain dipoles and diodes), dc-ac converters, electrical connections and supporting structures. To receive the circular microwave power beam which is $10 \mathrm{~km}$ in diameter, an elliptical rectenna is required at non-equatorial sites. For the study site at $36^{\circ} \mathrm{N}$ latitude, the ellipse would have a length of $13.4 \mathrm{~km}$ north-south and a width of $10.0 \mathrm{~km}$ east-west, enclosing an area of about 10,500 hectares (Piland, 1979).

The rectenna field would be flat or terraced to allow the end-to-end connection of rectenna panels in long, continuous rows. The rows would be spaced about four meters apart to prevent shading from the microwave beam and to allow for vehicular access between the rows. As described by General Electric about 45 kilometers of gravel roads (probably about six meters wide) would be located within the rectenna field to provide access to all parts of the field (General Electric, 1979). Surrounding the rectenna field will be a fenced buffer zone, to prevent people and animals from inadvertently entering the low-intensity fringes of the microwave beam. As currently conceived this buffer zone would be one kilometer wide along the eastern and western edges of the rectenna field. In order to achieve a uniform level of microwave radiation around the entire rectenna field, the buffer zone also would be elliptical. At $36^{\circ} \mathrm{N}$ latitude, the buffer zone thus would be 1.35 kilometers along the northern and southern edges of the rectenna (Schwenk, 1979). This exclusion or buffer zone will contain ancillary elements of the GRS, but will be closed to all unauthorized persons during operation of the GRS.

\subsubsection{RECTENNA FIELD COMPONENT DESCRIPTIONS}

\subsubsection{Panel Components}

The rectenna contains about 2.5 million panels ( 3 meters by 10 meters). Each panel consists of roughly 3,000 diode/dipole elements. The dipoles are "T" shaped, with a height of a few inches. Each dipole has a diode associated with it which converts the incident electromagnetic radiation into dc electricity. These dipole/diode elements are supported by a steel frame. A wire mesh groundplane serves to reflect incident microwave radiation back to the dipole/diodes which are supported in front of it. 


\subsubsection{Support Structures and Foundations}

To position each two-panel rectenna module ( $6 \times 10$ meters), a support structure consisting of concrete and steel arches with a foundation of concrete footings would be used (General Electric, 1979). Three of the arches would support each two-panel rectenna module, as illustrated in Figure 2.1-1. Each arch is composed of pre-cast concrete which is pre-stressed and reinforced with steel. The weight of an individual arch will be approximately $1,200 \mathrm{~kg}(1,100$ $\mathrm{kg}$ concrete and $100 \mathrm{~kg}$ steel). A typical arch is illustrated in Figure 2.1-2. The foundation for the support structure of a rectenna module consists of six cylindrical concrete footings ( 0.9 meter diameter, 1.5 meter depth), one for each of the legs of the three arches. For each footing about $1,100 \mathrm{~kg}$ of concrete is required.

\subsubsection{ELECTRIC POWER COLLECTION SYSTEM}

The GRS electric power collection system of the GRS collects dc electrical power from the rectenna field, converts it to ac power and transforms it to a voltage suitable for transmission.

The electric power collection system consists of 125 converter stations, 25 collection/transmission stations, and five step-up switching stations along with the busses and power transmission lines required for electrical connections (Boeing, 1978) (see Figure 2.1-3).

The dc electric power output of the rectenna field will be collected by a system of busses within the rectenna field, yielding 125 blocks of $40 \mathrm{MW}$ at $2 \mathrm{kV}$ dc. Each of these 125 blocks is connected to a $40 \mathrm{MW}$ converter station where the $2 \mathrm{kV}$ dc power is converted and transformed to $69 \mathrm{kV}$ ac. The field requires 125 of these converter stations.

The power output of the converter stations is then collected in groups of $f$ ive, forming twenty-five $200 \mathrm{MW}$ power blocks. Each of these is connected to one of 25 collection/transformer stations where the power is transformed from $69 \mathrm{kV}$ ac to $230 \mathrm{kV}$ ac. Each of these stations consists of a switchyard, transformers and a control house.

The 200 MW output from each of the collection/transformer stations is then also collected in groups of five, forming five 1,000 MW power blocks. Each of these blocks is connected to one of five 1,000 MW step-up switching stations where the power is transformed from $230 \mathrm{kV}$ ac to $500 \mathrm{kV}$ ac. The 1,000 MW of $500 \mathrm{kV}$ ac power from each of these step-up switching stations can be tied directly to the electric power transmission system or a $500 \mathrm{kV}$ ac buss could be used to collect this power before transmission.

\subsubsection{PERMANENT ANCILLARY FACILITIES}

Permanent ancillary facilities for the GRS include a control center, maintenance facilities, provisions for vehicle access and parking, security facilities, and a small wastewater treatment or disposal system.

The control center for the GRS monitors the position of the satellite, inicrowave beam characteristics, and the GRS power distribution network. The control 


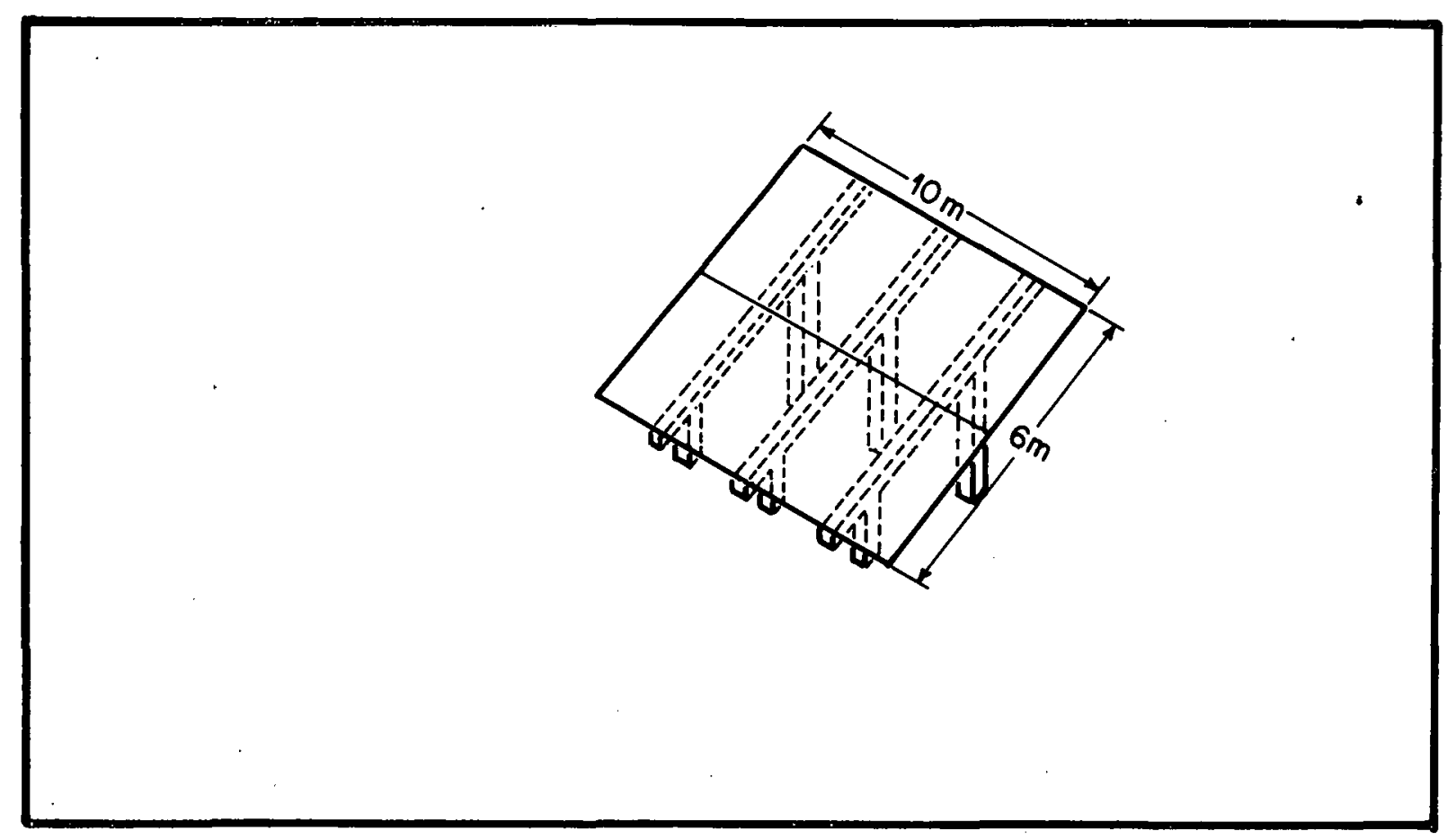

Figure 2.1-1. TWO-PANEL RECTENNA MODULE AND SUPPORT STRUCTURE (SOURCE: GENERAL ELECTRIC, 1979)

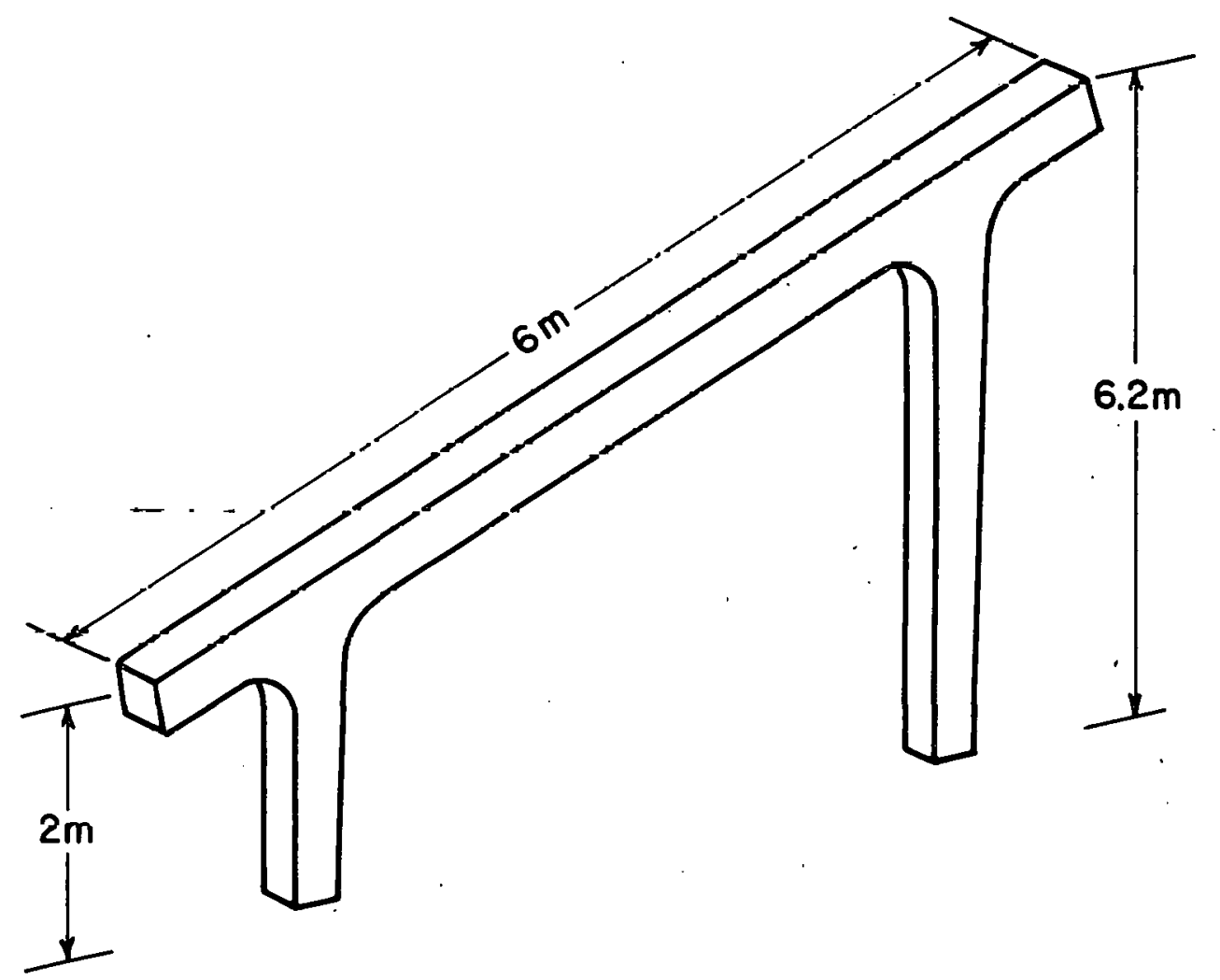

Figure 2.1-2. RECTENNA ARCH (SOURCE: GENERAL ELIECTRIC, 1979) 


\begin{tabular}{|c|c|c|c|c|c|c|c|}
\hline $\begin{array}{c}40 \mathrm{MW} \\
\text { Rectenna Power }\end{array}$ & $2 k V$ & $\begin{array}{l}\text { 40MW } \\
\text { Converter }\end{array}$ & $69 \mathrm{kV}$ & $\begin{array}{l}200 \mathrm{MW} \\
\text { Collection/ }\end{array}$ & $230 \mathrm{kV}$ & $\begin{array}{l}1000 \mathrm{MW} \\
\text { Step-up } \\
\text { Switching }\end{array}$ & $500 \mathrm{kV}$ \\
\hline $\begin{array}{l}\text { Blocks } \\
(125)\end{array}$ & $D C$ & $\begin{array}{r}\text { Stations } \\
(125)\end{array}$ & $A C$ & $\begin{array}{c}\text { Stations } \\
(25)\end{array}$ & $A C$ & $\begin{array}{c}\text { Stations } \\
\text { (5) }\end{array}$ & $A C$ \\
\hline
\end{tabular}

Figure 2.1-3. ELECTRIC POWER COLLECTION SYSTEM SCHEMATIC DIAGRAM

(Based on General Electric, 1979) 
center can then log these data and control satellite attitude and microwave beam output, regulate the GRS power distribution network accordingly, and implement emergency shutdown procedures for the various parts of the SPS as needed. The control center of the GRS would be located at the site in a separate building which would also house administrative personnel, management and maintenance workers, as well as displays, computers, and controls. Beyond a brief, preliminary discussion of these basic functions and the assignment of a cost estimate of $\$ 75$ million (Rockwell, 1979), there is no other information presently available which further characterizes the GRS control center.

Maintenance facilities will be housed in the materials handling and service building, after construction is completed. This building will contain craft shops, storage, and equipment maintenance areas.

The provisions for vehicle access and parking include the main access road and a paved parking lot. The road will be a high quality paved road, designed for use by heavy trucks and equipment as well as other vehicles during both the construction period and the operational phase. This road will connect the GRS site with the nearest highway, U.S. Highway 395, which lies to the west of the GRS site. Temporary secondary access roads and a $16 \mathrm{kilometer}$ rail spur will be built and used during the construction period.

The security facilities for the GRS include a perimeter fence located outside the buffer zone around the rectenna field and a security gate house located al ong the main road at the fence. In addition, a gravel patrol road will run along the inside of the perimeter fence. Both the patrol road and the perimeter fence will be about 45 kilometers in length.

A system would have to be developed to provide for treatment and disposal of the wastewater produced during the operational phase of the GRS. It is not possible to specify the type of system that would be selected (sewer and wastewater treatment system, septic tank. etc.), but a sewer and treatment system seems unlikely since the GRS will have a permanent labor force of only 300. In addition, a system of drains and culverts will provide for stormwater drainage and erosion control from the control and maintenance area, as well as from the rectenna field.

\subsubsection{GROUND RECEIVING STATION OPERATIONS}

The operation of the GRS has not yet been addressed in detail by NASA or its contractors. Table 2.1-1 presents labor requirement.s and estimate en maintenance materials cost as presented in the Rockwell concept definition study (Rockwell, 1979). Operation of the GRS will include managing the control center, maintenance of the GRS facilities and site, provisions for security, and general and administrattve support.

The General Electric study also provides some estimates for labor requirements, specifically for the maintenance and repair functions of the rectenna field and electric power collection system (General Electric, 1979). It is estimated in this study that 127,000 man-hours per year would be required for scheduled and unscheduled maintenance. Maintenance thus would require a workforce of about $64 \mathrm{men}$, which is in reasonable agreement with the estimates developed by Rockwell and presented in Table 2.1-1. 
Table 2.1-1. GRS OPERATION REQUIREMENTS ${ }^{1}$

\begin{tabular}{|c|c|c|c|c|}
\hline ITEM & SHIFT & NO. & TOTAL & 1977 DOLLARS \\
\hline \multicolumn{5}{|l|}{ - Operations \& Maintenance Personnel } \\
\hline $\begin{array}{l}\text { Command \& Control Center } \\
\text { (Personnel }+ \text { Supervisory) }\end{array}$ & $\begin{array}{l}1 \\
2 \\
3\end{array}$ & $\begin{array}{l}30 \\
30 \\
20\end{array}$ & 80 & \\
\hline $\begin{array}{l}\text { Converter Station } \\
\text { (Total for } 12 \text { Stations) }\end{array}$ & $\begin{array}{l}1 \\
2 \\
3\end{array}$ & $\begin{array}{l}36 \\
36 \\
36\end{array}$ & 108 & \\
\hline \multirow{2}{*}{$\begin{array}{l}\text { 24-Hour Maintenance, Repair, } \\
\text { Security, \& G\&A/Support }\end{array}$} & & 112 & 112 & \\
\hline & & & $300^{2}$ & \\
\hline $\begin{array}{l}\text { o Maintenance Material. (Expendables, } \\
\text { Trucks, Equipment, Ut ilities, } \\
\text { Test/Support Equipment) }\end{array}$ & 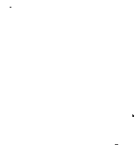 & & & 13,000 \\
\hline
\end{tabular}

1. Source: Rockwell, 1979.

2. When days off and vacations are taken into account, roughly 450 workers will be required to fili the 300 permanent jobs. 


\subsection{GROUND RECEIVING STATION CONSTRUCTION}

\subsubsection{INTRODUCTION}

The construction of a 5,000 MW Ground Receiving Station (GRS) is described in the following sections. It was assumed that the GRS would be built over a 25-month period as proposed by General Electric (General Electric, 1979). Construction will be described in terms of the major elements listed below. Figure 2.2-1 describes the sequence and schedule for the major elements of GRS construction.

- Preliminary construction activities

- Rectenna field site preparation

- Rectenna construction

- Electric power collection facilities construction

- Other construction and pre-operalions activities

\subsubsection{PREL IMINARY CONSTRUCTION ACTIVITIES (Months 1-8)}

Preliminary construction activities encompass initial site survey and engineering, followed by installation of construction support facilities. Construction support facilities installation will include development of site access roads and a railroad spur, provision of utilities (water, electricity), provision of necessary construction facilities and buildings, and provision for personnel housing requirements. Requirements for these preconstruction activities are based on information developed by Rockwell, Boeing and General Electric, as well as supplementary data obtained from southern Cal ifornia utilities and from United Engineers and Constructors (see Appendix A).

In the first two months of the GRS construction schedule, the initial site survey and engineering activities will establish various reference points with regard to the rectenna field site and the location of the construction support facilities. The main access road, assumed to be $16 \mathrm{kil}$ ometers in. length at the prototype study site, will be constructed during this period to connect the construction support facilities site with U.S. Highway 395, which will serve as the primary vehicular access route. This main access road will be a high quality paved road, capable of accommodating heavy trucks and equipment. Construction of a rail spur for materials delivery to the site will also commence during this period. A nominal $16 \mathrm{~km}$ of rail spur are expected. Railroad construction is expected to be completed during the eighth month of the GRS construction period.

Arrangements for the housing of the construction work force (and their dependents, to the extent that dependents accompany the project workers) will have to be made during this period. Various alternative arrangements are possible, ranging from providing mobile-home type temporary housing units in an on-site construction camp, to leaving all workers to make the ir own housing arrangements in nearby communities. A typical arrangement for large, rural construction projects is to provide recreational vehicle parking spaces, with water and electric power hookups, as it is common for construction workers to use such vehicles (i.e. campers, trailers, vans) for travel to the work site from their permanent residences (or from their previous work location). Some mobile-home type units also may be required. 


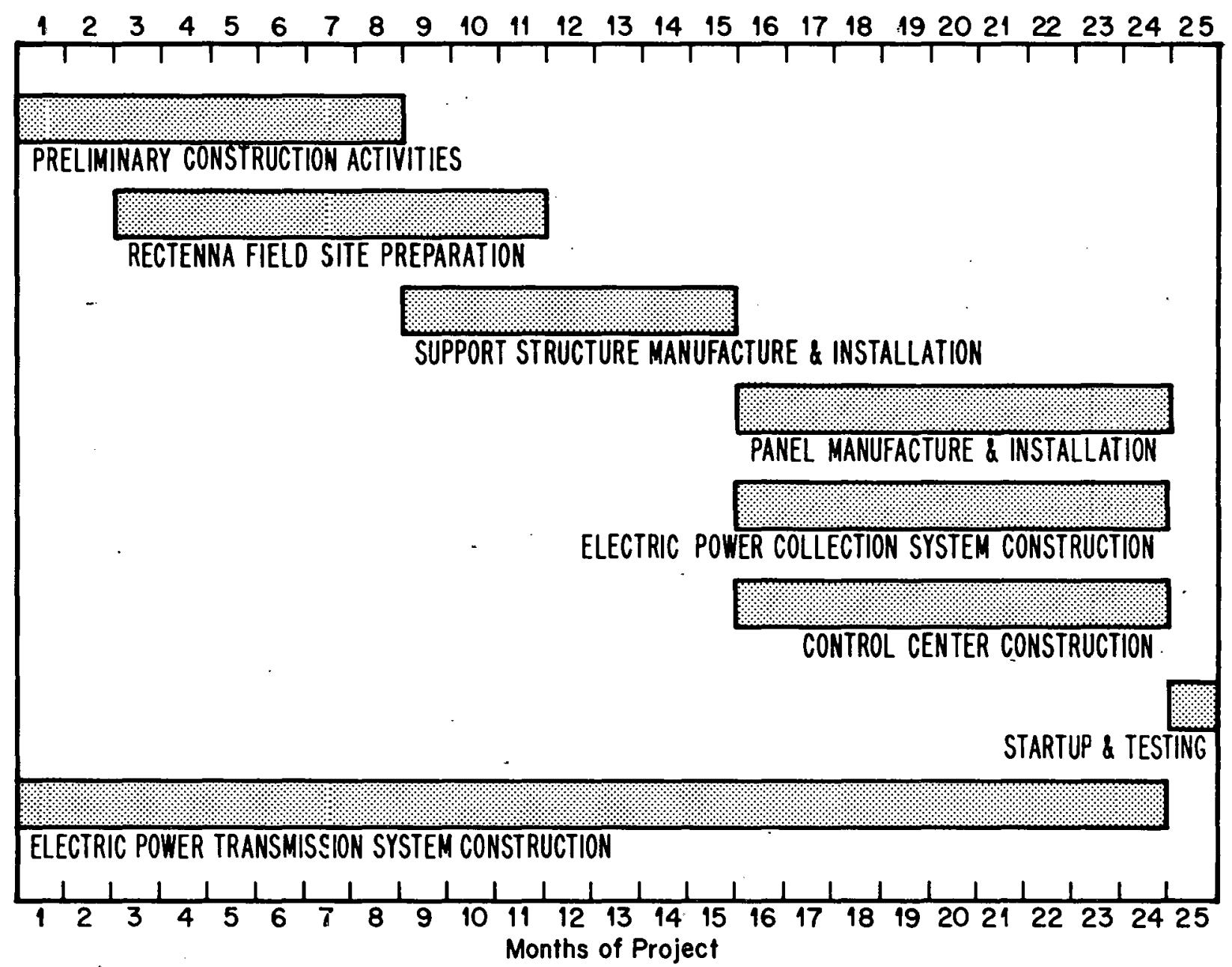

Figure 2.2-1. SCHEDULE OF MAJOR GRS CONSTRUCTION ACTIVITIES (Based on General Electric, 1979) 
The first two'months of the above activities (site survey/engineering, road and rail construction, temporary housing development) are estimated to require a work force of about 300 .

In addition, development of on-site water and electricity supplies for the remainder of the construction period must be provided. Water could be brought in by pipeline from nearby sources, or from onsite wells if sufficient groundwater of adequate quality is available.

Electricity requirements could be met by building a transmission line to connect with existing utility lines, or by utilizing a new $500 \mathrm{kV}$ ac transmission line. constructed for the project's power delivery. A second option would involve the use of diesel generators (for interim electricity supplies) onsite.

Months 3-8 of the GRS construction schedule involve the beginning of rectenna field site preparation (discussed separately in Section 2.2.2), completion of the required rail spur, and installation of all other significant construction support tacilities. The installation of construction support facilities involves the necessary yardwork and site preparation, the erection of the various temporary buildings and facilities common to most large power supply construction projects, and the construction of other support facilities which, due to the nature of the rectenna requirements and the concepts developed for rectenna construction, are required for this project. Yardwork and site preparation includes the provision of a perimeter fence around the entire GRS site, and a security gate house as well as fencing around the construction support facilities site proper. In addition, grading and cut and fill operations, as required, for temporary buildings, roads, parking, storage areas, and site drainage would be completed during this period. Permanent and temporary roads, as well as parking and storage areas would also be developed.

In addition, during this six-month period, various typical temporary construction facilities would be installed. These facilities would include materials receiving and storage facilities, craft shops and tool rooms, restroom facilities, equipment maintenance and service facilities, and temporary administrative offices. In addition, provisions must be made for distribution of electricity and water supplies throughout the construction site.

Special requirements for construction support facilities for the GRS include a large concrete plant capable of producing approximately 6.5 million cubic yards of concrete during the seven months of rectenna panel support arch manufacture and installation. Also required are an arch factory which will produce about 3.7 million arches in seven months, and a panel manufacturing factory which will fabricate about 2.5 million rectenna panels in nine months. Output requirements for the concrete plant, arch and panel factories are based on data presented by General Electric (General Electric, 1979).

It is anticipated that for this six month period (Months 3 through 8 of the GRS construction schedule), preliminary construction activities will require a work force of about 1,300: 1,200 for the installation of construction support facilities and 100 for the completion of the rail spur. 


\subsubsection{RECTENNA FIELD SITE PREPARATION (Months 3-11)}

The major axis of the elliptical rectenna field is oriented North-South; at $36^{\circ}$ North latitude the ellipse would have a major axis of $13.4 \mathrm{~km}$ and a minor axis of $10.0 \mathrm{~km}$ (Piland, 1979). The entire area within this ellipse is to -be devoted to the rectenna field and the site must be prepared accordingly.

After coordinates have been established for the rectenna field site, the site must be cleared, leveled or terraced, and graded for the rectenna panel. foundations. An area of 10,500 hectares $(26,000$ acres) must be prepared for the 5 GW GRS; it has been assumed that this job would be accomplished in nine months (Rockwell, 1979).

To complete rectenna field site preparation in nine months, it is estimated that there will be approximately 800 workers on the site each day during the nine-month period (seven days per week, one shift per day). This will require a workforce of approximately 1,100. About 600 large vehicles will be required, including road graders, bulldozers, earthmovers, dump trucks, cranes and backhoes. These vehicles are expected to consume approximately 370 tonnes of fuel per daj, 11,000 tonnes per month, and 100,000 tonnes for the entire rectenna site preparation task.

At the relatively lightly vegetated Coso site, it is expected that about 490,000 tonnes (67,000 dry.tonnes) of vegetation will have to be removed from the 10,500hectare rectenna field site and disposed of either by landfill or by burning. Shredding or mulching of vegetative wastes, possibly leaving a salable product also is a possibility.

After the rectenna field site has been cleared and graded properly, about 45 kilometers of gravel roads will be built to provide efficient access for vehicles to the entire rectenna field (General Electric, 1979) (see Figure 2.2-2).

\subsubsection{RECTENNA CONSTRUCTION (Months 9-24)}

Actual construction of the receiving antenna would consist of two distinct phases. First, the rectenna panel support arches must be manufactured and then installed in the prepared rectenna field site. Then, the rectenna panels themselves are assembled, tested; and installed on the support structures and rectenna field wiring is completed. General Electric's rectenna construction analysis (General Electric, 1979) was used as the basis for the descriptions of rectenna structure and panel manufacture and installation which follow.

\subsubsection{Support Structure Manufacture and Installation (Months 9-15)}

Rectenna support structure manufacture and installation is expected to require approximately seven months. In this time, a detailed survey of the site must be accomplished in order to mark out precise positions for rectenna support structure emplacement; concrete footings must be emplaced for each support structure, and the support structures themselves must be manufactured and then installed in the foundations.

As currently conceived, rectenna panels will be 3 meters wide by 10 meters in a length; a total of approximately 2.5 million panels are required for the rectenna field (General Electric, 1979). Two panels will be installed on each support structure, which consists of 3 arches, so that about 1.24 million support structures (or 3.7 million arches) are needed. In the detailed site 


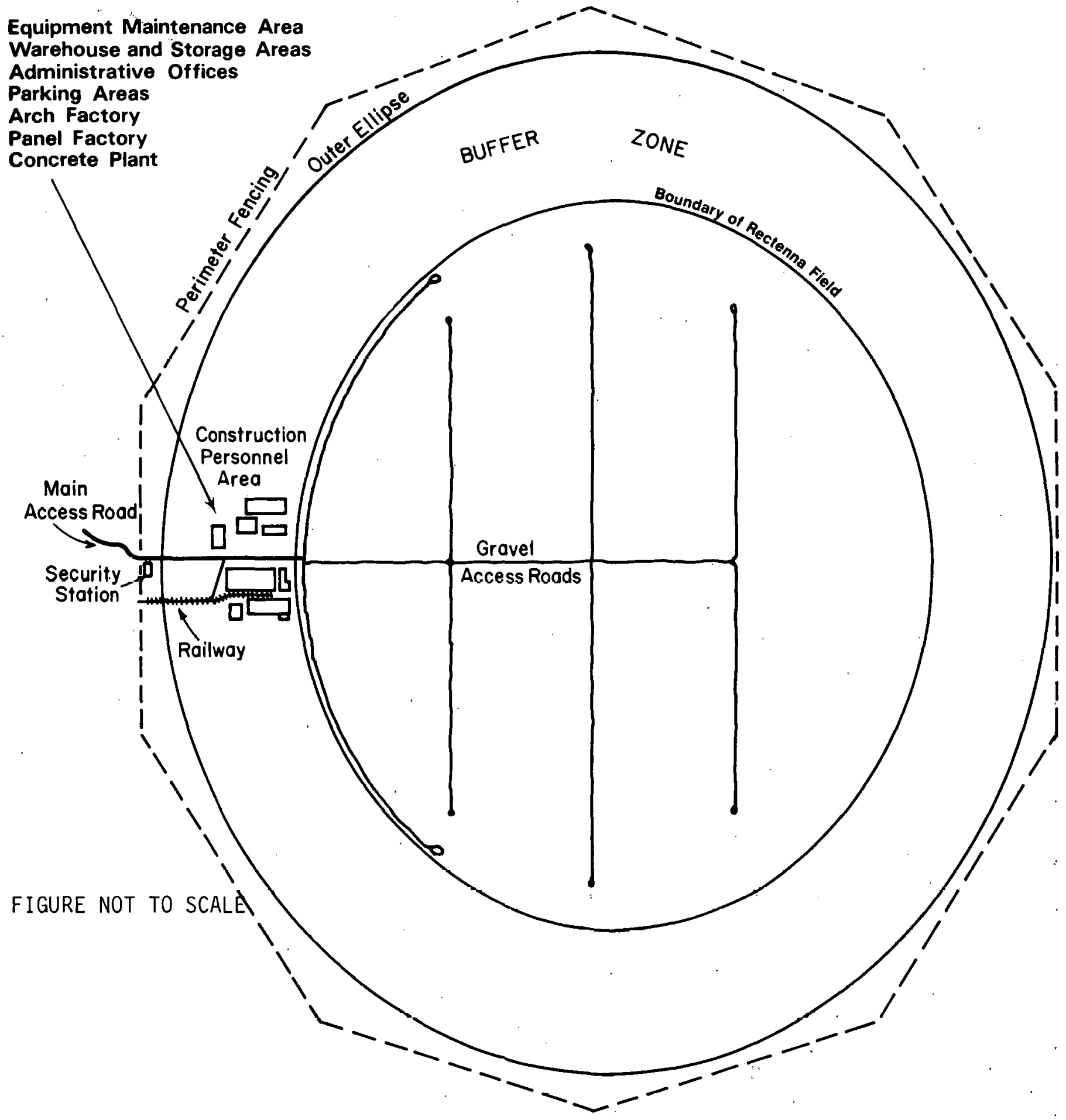

Figure 2.2-2. GRS CONSTRUCTION PHASE: SCHEMATIC LAYOUT (Based on figures presented in General Electric, 1979 and Rockwel1, 1979) 
survey, positions for one of every ten arches would be precisely marked, using 20 special survey vehicles.

Each arch has two legs, and a concrete footing is required for each. Specialized machines equipped with combination auger-jackhammer units and rock: drilling machines would be utilized to dig the footing holes in the rectenna field. Specially designed footing machines then would pour concrete into the footing holes, leaving a space in the center for the leg of the arch which will be installed. Redi-mix concrete trucks would transport concrete from the concrete factory to the footing machines.

The panel-supporting arches would be produced by ten arch-making factories located adjacent to the concrete factory (Fig. 2.2-2). The arches would be delivered to the rectenna field by. truck, installed by cranes, and sealed in place with grout: During the seven-month phase of arch manufacture and .installation, about 6.5 million cubic yards of concrete must be produced (General Electric, 1979) (see Table 2.2-1).

\subsubsection{Rectenna Panel Manufacture and Installation (Months 16-24)}

Rectenna panel manufacture and installation would require approximately nine months. In this period about 2.5 million rectenna panels would be manufactured, tested, and installed, and the appropriate electrical connections within the rectenna field completed.

- Rectenna panels would be manufactured in two basic steps in the rectenna panel assembly area (Fig. 2.2-2). In the first step, 120 foreplane assembly machines form the basic panel receptor elements which are then assembled into the $3 \mathrm{~m} x$ $10 \mathrm{~m}$ panels. The panels must be tested and then transported to the rectenna field by truck, where they will be installed on the support structures. Then the appropriate cables are installed and attached to the panels and the complete electrical wiring of the field installed. Requirements for materials, labor, and vehicles and equipment for this phase are tabulated in Table 2.2-1.

\subsubsection{ELECTRIC POWER COLLECTION SYSTEM (Months 16-24)}

$\because:$

The electric power collection system of the GRS would serve to collect the dc. electrical power from the rectenna field, convert it to ac, and transform it to voltages suitable for transmission. The transmission system would deliver SPS generated power to interties with the regional electrical grid, for further distribution and ultimate consumption.

The electric power collection system described here is as defined by the Boeing concept definition study (Boeing, 1979). The dc electric power output of the rectenna field would be collected to the level of one hundred twenty-five 40 MW blocks ( $2 \mathrm{kV} \mathrm{dc}$ ), and converted to $69 \mathrm{kV}$ ac. This would require the installation of an extensive-cabling network and 125 converter stations within the rectenna field.

Cable would be installed. to. connect the output of the 40 MW converter stations to the $200 \mathrm{MW}$ collection/transformer stations which transform the ac power from $69 \mathrm{kV}$ to $230 \mathrm{kV}$. Tienty-five of these collector/transformer stations must be installed near the perimeter of the rectenna field. Overhead transmission lines will be installed to connect the output of the $200 \mathrm{MW}$ collection/transformer stations to five 1,000 MW step-up switching stations. 
Table 2.2-1. REQUIREMENTS FOR MATERIALS, LABOR, VEHICLES AND EQUIPMENT FOR RECTENNA SUPPORT AND PANEL MANUFACTURE AND INSTALLATION 1

Requirements

Phases (of Manufacture and Installation)

Support Structures Panels

Materials:

Concrete. (cubic yards)

$6,500,000$

Rolled Steel (tonnes)

370,000

$1,300,000$

A1 unt nlum (tomes)

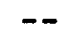

170,000

Plastic Insulation (tonnes)

3,800

12,000

Ceramic (tonnes)

$--$

5,900

Diodes (number)

$--$

$7.5 \times 10^{9}$

Workforce

1,600

1,100

Number of Major Vehicles and Equipment

700

250

Fuel Use (tonnes) 2

80,000

190,000

Time of Construction (months)

7 (Months 9-15)

9 (Months 16-24)

1. See Appendix A for derivation of these data.

2. A specific gravity of 0.85 is assumed. 
Construction of the 25 collection/transformer stations and the five step-up switching stations would require foundation site preparation and installation for the switch yards and control houses of these facilities, the erection of the switchyards and control houses, and completion of all the required electrical connections. The construction of the electric power collection system will be undertaken in Months 16 through 24 of the GRS construction schedule, concurrent with the manufacture and installation of the rectenna panels. A workforce of approximately 500 will be required for this nine month task.

\subsubsection{ADDITIONAL CONSTRUCTION AND PRE-OPERATION ACTIVITIES (Months 3-24)}

Additional construction and pre-operation activities which have yet to be discussed include construction of the GRS control center and various other permanent support structures, transportation of materials to the site, equipment maintenance activities, administrative and engineering support at the site, general cleanup operations, and startup and testing activities. Each of these activities are discussed in this section.

The control center for the GRS would control and monitor the operations and attitude of the satellite, and the GRS power distribution network. It will also house the GRS administrative, operational, and maintenance personnel and the displays, computers, and controls required. The control center would be constructed during a nine month period (Months 16-24).

In addition to the items noted above, receiving, storage and handling facilities, as well as a wastewater disposal system must be developed. It is estimated that about 1,100 workers would be required for the construction of these support facilities and operations.

GRS construction would require the delivery of substantial amounts of material and equipment to the site. It is assumed that a mix of both truck and rail transportation would be employed. For the first eight months of the GRS construction schedule, i.e. until the railroad spur is completed, trucks would be used exclusively to bring in materials, equipment, and supplies for the preliminary construction activities and rectenna field site preparation. From the ninth month onward, rail transportation would likely be used for the major part of the bulk shipments which are to occur. Alternatively the rail spur could be constructed earlier and used throughout the construction period. However, the rail system would not be absolutely critical until the ninth month of the project, when actual rectenna construction commences and the demand for materials increases dramatically.

Bulk shipment of materials to the construction site would be at its peak during the period of rectenna support structure fabrication and foundation installation, Months 9 through 15 of the GRS construction schedule. During this period, approximately 10.1. million tonnes of aggregate and $1.4 \mathrm{million}$ tonnes of cement would be required for concrete production. In addition, 370,000 tonnes of steel and 3,800 tonnes of plastic insulation would also be required. If a unit train capacity of 9,100 tonnes is assumed, based on a single car capacity of 91 tonnes, and train capacity of 100 cars (Fath, 1979), and approximately 11.9 million tonnes are transported by train, then roughly 1,300 train loads would be required for transport of materials to the site during Months 9 through 15 . This is equivalent to 6.2 unit trains per day. It is likely that some of the materials would be transported to the site by truck during this period, however. If all materials were transported by truck, and an average payload of 23.6 
tonnes is assumed, based on the cement and aggregate hauling capacities of trucks used by Conrock Co., a southern California concrete and aggregate supplier (Lang, 1979), then 504,000 truck loads would be required. This is equivalent to 2,400 truck loads per day.

Other critical activities during the construction period include equipment and vehicle maintenance and service, and administration, engineering, and quality assurance activities. These activities are estimated to require a workforce of 200-300 people during Months 3 through 24 of the construction schedule.

For the final month of the GRS construction schedule the primary activities would be cleanup and facility startup and testing. General cleanup operations would begin in Month 16 of the GRS construction schedule (when support structure manufacture and installation have been completed) with a workforce of 200. However, in the last month of the construction period (Month 25) this workforce would be increased to 700 to complete the job of dismantling and removing the temporary construction support faclifties. To test all the component systems of the GRS and to achieve complete coordination with satellite operations, a period of intensive testing would be required for the last month of the construction period. It is estimated that a workforce of about 300 would be required for the testing procedures and startup. Upon completion of construction, cleanup, and testing and startup operations, the GRS would go into operation, provided that the transmission lines are completed and the utility interties have been appropriately expanded.

\subsubsection{SUMMARY OF MAJOR CONSTRUCTION REQUIREMENTS}

In this section the major requirements for the construction of the GRS will be summarized in six categories (a detailed analysis of construction requirements is presented in Appendix $A$ ):

- Labor Requ1rements

- Materials Requirements

- Utility Requirements (water and electricity)

- Vehicle and Equipment Requirements

- Solid and Liquid Wastes

- Construction Costs

\subsubsection{Labor Requirements}

Construction of the GRS is estimated to require about 10 million man-hours and an average workforce of 2,500 over a 25-month period. A peak onsite workforce of approximately 3,200 would be required during Months 16 through 24 of the construction schedule. Figure 2.2-3 presents the monthly labor force requirements throughout the 25 month construction period. Rectenna field site preparation would involve day shift. work only (Rockwel.1, 1979), but rectenna construction itself would require a significant level of multishift activity (General Electric, 1979). Other GRS construction activities could require either single or multiple shifts.

\subsubsection{Materials Requirements}

Table 2.2-3 summarizes materials requirements for GRS construction. Transportation of the materials required at the site by unit train would require 


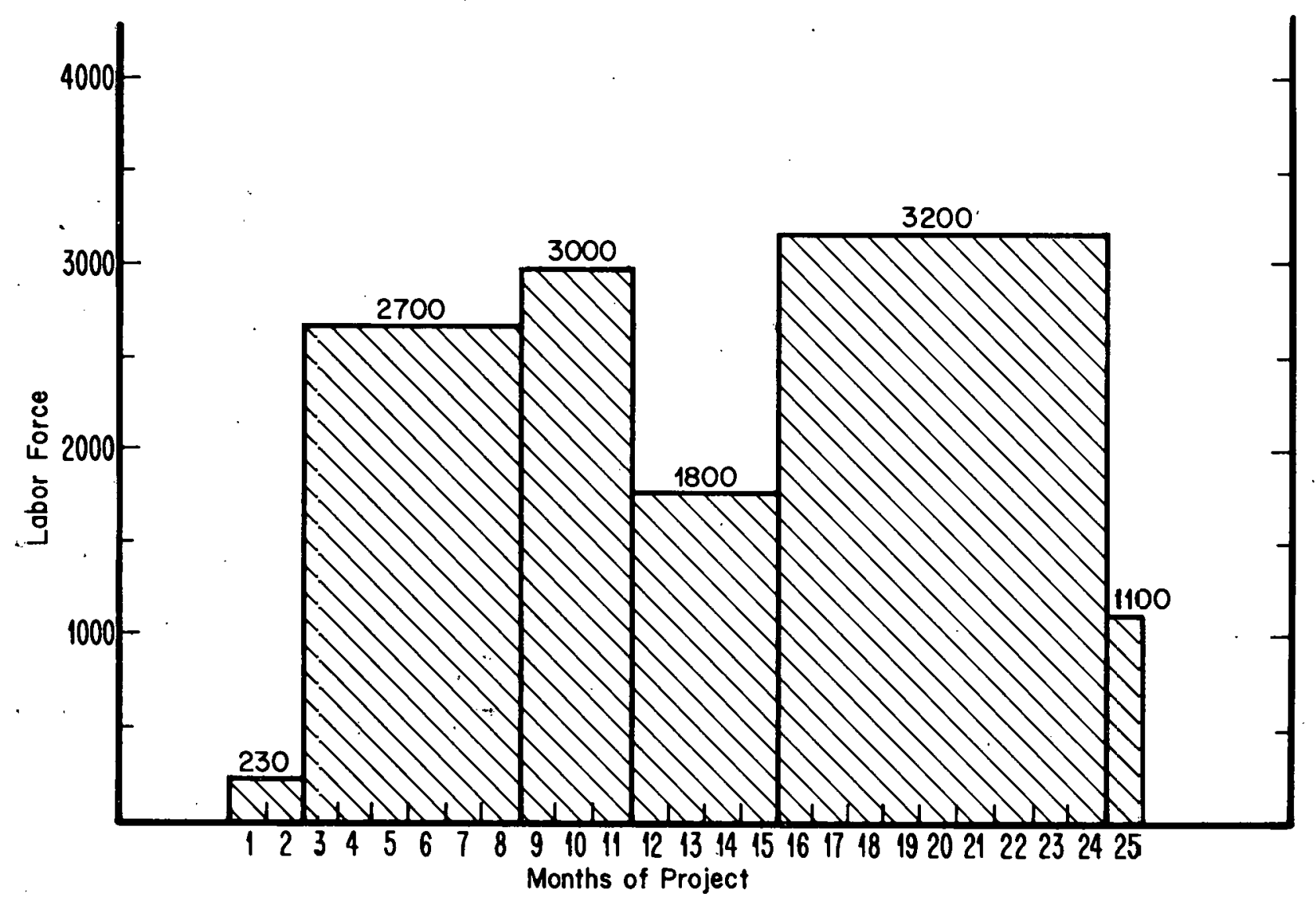

Figure 2.2-3. GRS CONSTRUCTION PHASE LABOR REQUIREMENTS

Source: See Appendix A. 
Table 2.č-2. MATERIALS REQUIREMENTS FOR GRS CONSTRUCTION

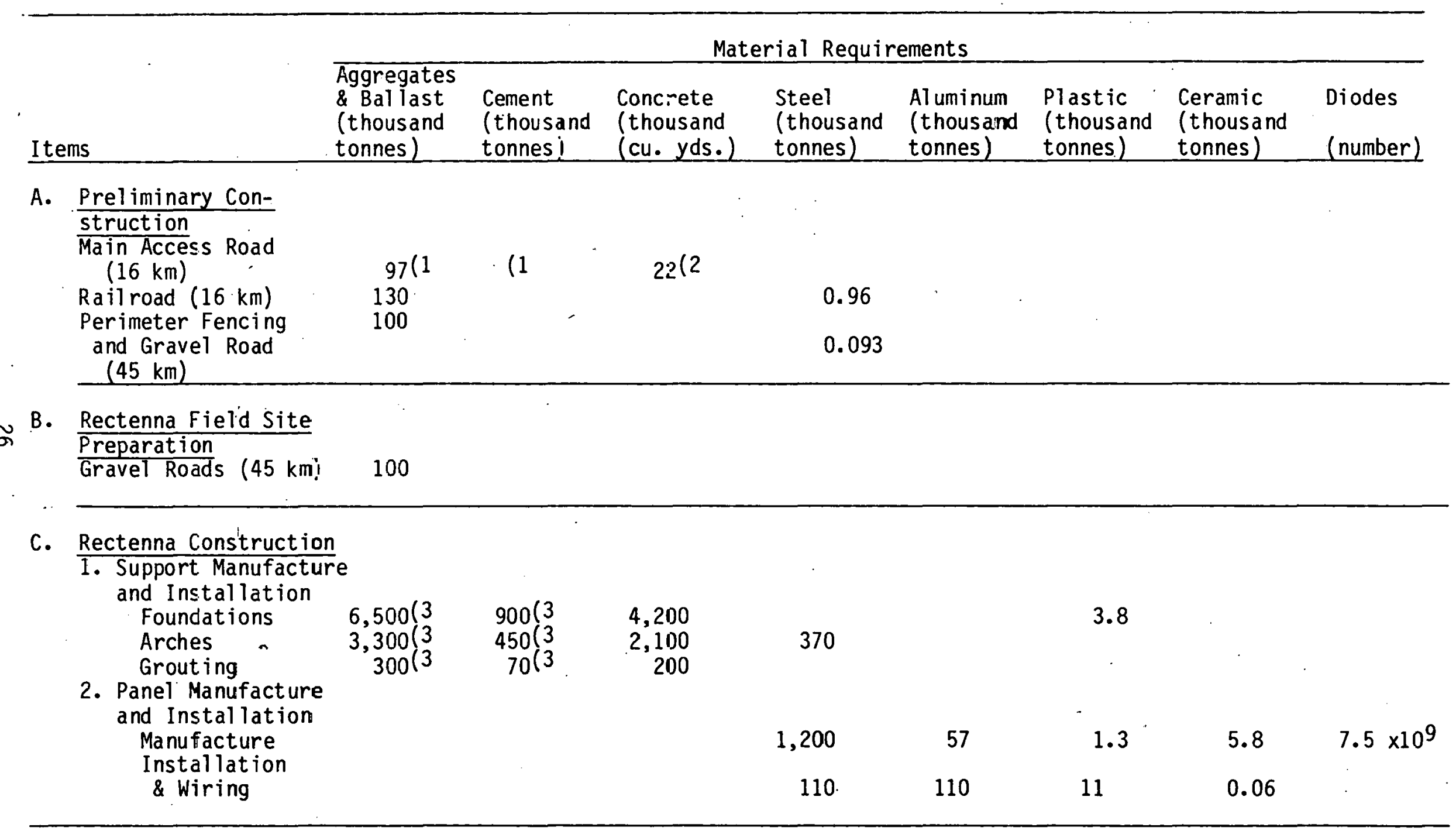


Table 2.2-2. MATERIALS REQUIREMENTS FOR GRS CONSTRUCTION (continued)

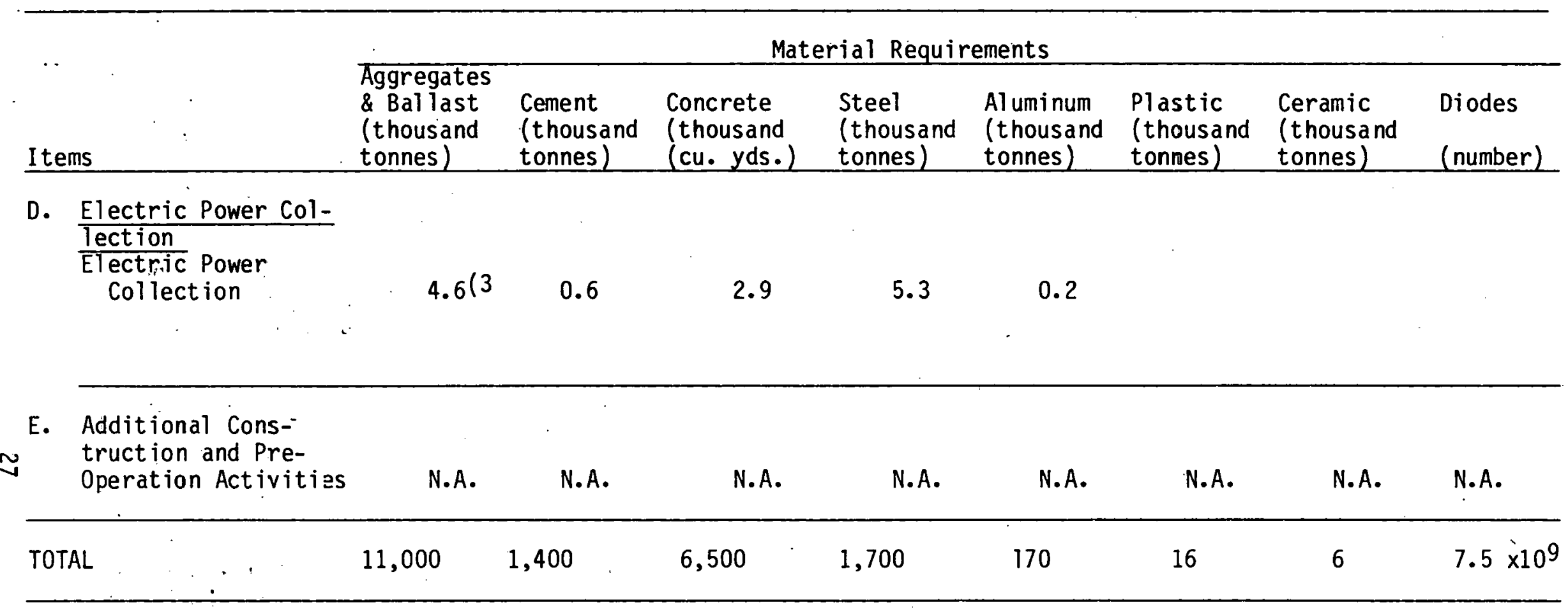

1. Cement and aggregate for asphaltic concrete not included.

2. Asphaltic concrete.

3. For non-asphaltic concrete. 
about. 6.2 unit trains per day (or 2,400 truck trips per day or a combination of rail and truck) during Months 9 through 15, and 0.6 unit trains per day for Months 16 through 24 (without consideration of requirements for the control center).

\subsubsection{Utility Requirements}

GRS construction, including labor force associated consumption, will have a maximum annual water demand of 1.8 to 13.0 million cubic meters. The broad range is due primarily to uncertainty regarding the means employed to control fugitive dust emissions.

GRS construction will have a maximum electricity demand of $10 \mathrm{MW}$, and the construction-related population will demand a maximum additional $6 \mathrm{MW}$.

\subsubsection{Vehicle and Equipment Requirements and Fuel Consumption}

Major onsite vehicle and equipment requirements are for rectenna field site preparation, 600 vehicles; rectenna support structure manufacture and installation, 700 vehicles and machines; rectenna panel manufacture and installation, 250 vehicles and machines; and electric power collection system construction, 360 vehicles and machines. Fuel consumption for onsite construction activities will include 120 million liters for rectenna field site preparation, 94 million liters for support structure manufacture and installation, 230 million liters for rectenna panel manufacture and installation, and 980,000 liters for electric power collection system construction. Figure 2.2-4 presents the vehicle and equipment requirements and fuel consumption for Months 3-24 of the construction period.

\subsubsection{Solid and Liquid Wastes}

Rectenna field site preparation (Months 3 to 11) will produce roughly 1,800 tonnes per day of vegetative wastes which will require disposal.

Rectenna panel manufacture and installation (Months 16-24) will produce about 5 tonnes of solid waste, primarily metals, per day.

The construction related population will produce a maximum of 18 tonnes of domestic solid waste per day, and a maximum sewage flow rate of 1,500 cubic meters per day.

\subsubsection{Construction Costs}

The major costs for on-site construction are for rectenna field site preparation, $\$ 50$ million (labor: $\$ 20$ million); rectenna construction, $\$ 1.4$ billion (1abor: $\$ 49$ million); electrical power collection system construction, $\$ 120$ million (labor: $\$ 10$ million); and control center construction $\$ 75$ million (1abor $\$ 22$ million). Total onsite construction costs, as a result of this analysis, are approximately $\$ 1.7$ billion (labor: $\$ 130 \mathrm{million}$ ). (As noted in Appendix $A$, cost elements such as 1 and acquisition, offsite engineering and design, permits and fees, construction financing costs and insurance are excluded from the above estimate.) See Figure 2.2-5 for a presentation of monthly labor costs through the construction period. 


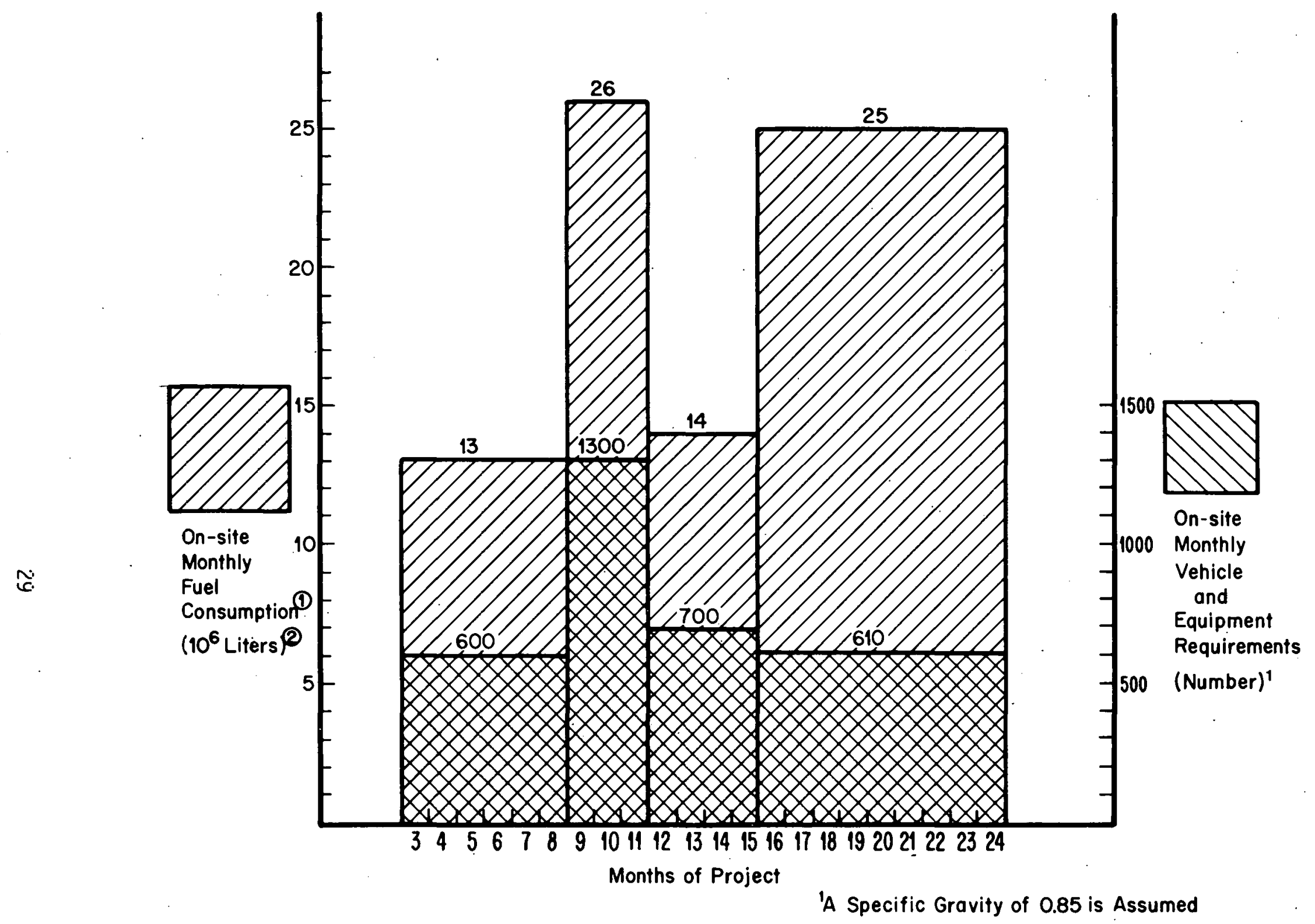

Figure 2.2-4. GRS MONTHLY CONSTRUCTION VEHICLE AND EQUIPMENT REQUIREMENTS AND ASSOCIATED FUEL CONSUMPTION

(Based on General Electric, 1979) 
$\omega$

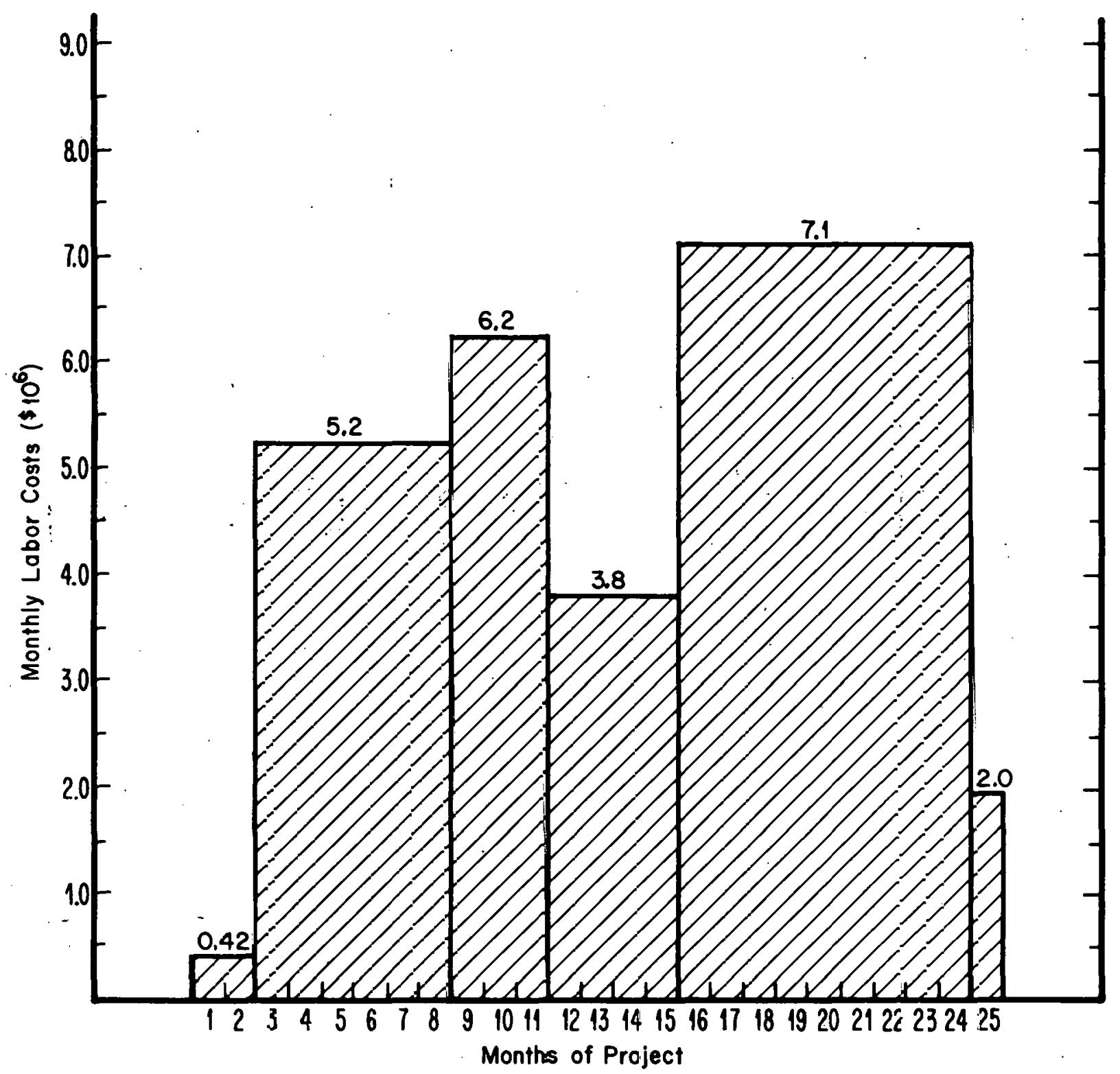

Figure 2.2-5. GRS CONSTRUCTION LABOR COSTS

Source: See ApFendix A. 


\subsection{ELECTRIC POWER TRANSMISSION SYSTEM}

\subsubsection{INTRODUCTION}

It has been assumed that $500 \mathrm{kV}$ ac overhead transmission lines would be used to transmit the $5,000 \mathrm{MW}$ of electric power from the GRS to the utility interties. Four or five of these lines would be required. Typically, the transmission lines are suspended on steel towers approximately 42 meters high, with concrete footings. Towers will be required at an average interval of about $0.4 \mathrm{kilometers}$ for each transmission line. A right-of-way of about 60 meters is assumed for a single $500 \mathrm{kV}$ ac 7 ine.

Significant modifications would likely be required at the utility interties receiving power from the GRS, but consideration of such modifications is beyond the scope of this study effort.

For a GRS site in the Coso vicinity, transmission lines presumably would connect the GRS to the nearest existing interties, i.e., near Los Angeles and Hoover Dam. However, only a detailed analysis, which is beyond the scope of this study, would identify the optimal routing for distribution of the power produced by the GRS. For purposes of estimating labor, vehicle, materials requirements for GRS transmission line construction, a requirement for 1,600 kilometers of $500 \mathrm{kV}$ ac lines is assumed.

\subsubsection{ELECTRIC POWER TRANSMISSION SYSTEM CONSTRUCTION}

Information on the construction of transmission lines is based on data obtained from two major southern California utilities, the Southern California Edison Company and the City of Los Angeles Department of Water and Power (LADWP, 1975, 1976; SCE, 1977). Estimated requirements are summarized in Table 2.2-4.

The construction of these transmission lines would require the detailed survey of the route; clearing and grading for access roads and temporary office sites, storage yards, concrete batch plants, tower sites, and conductor pulling sites; as well as the actual installation of the power lines. The installation of a $500 \mathrm{kV}$ power line will require the installation of concrete footings for the transmission towers, erection of the towers, the stringing and tensioning of conductors, and the grounding of towers.

The construction of the electric power transmission system is expected to occur throughout the first 24 months of the GRS construction schedule so that power can be delivered to the grid when the GRS is operational. Requirements for labor and other resources or services for construction are dependent on the length of transmission lines. This activity will not be centered at the GRS construction site; rather, resources and workers will be spread out along the transmission corridors. Presumably, sufficient material "and human." resources could be al located to transmission line construction (i.e. multiple crews), to accomplish the required construction and installation within this 24 month time frame. Alternatively, transmission line construction could be begun even before GRS construction begins. The basic assumption is that commencement of GRS operations would not be delayed merely because the transmission system is not completed in a timely manner.

Fulluwing dre the basic assumptions/derivations used to develop data on the SPS electric power transmission system: 
Table 2.2-3. REQUIREMENTS FOR CONSTRUCTION OF 1,600 KILOMETERS OF $500 \mathrm{kV}$ aC TRANSMISSION LINES

ITEM

QUANTITY

\section{Labor:}

Man-hours

$3,800,000$

Workforce

900

\begin{tabular}{lr}
\hline Materials: & \\
Aggregate (tonnes) & 68,000 \\
Cement (tonnes) & 9,600 \\
Concrete (cubic yards) & 44,000 \\
Steel (tonnes) & 50,000 \\
Aluminum (tonnes) & 32,000 \\
\hline Vehicles and Machines: & 640 \\
Number & 980,000 \\
Fuel consumption (1iters) & 980,000 \\
$\quad$ Gasnline & \\
Diesel & $\$ 45,000,000$ \\
\hline Construction Costs (1977 dollars) & $\$ 200,000,000$ \\
Labor & $\$ 280,000,000$ \\
Non-Labor & \\
$\quad$ Total Cost & \\
\hline
\end{tabular}

Source: See preceding text. 
- Workforce estimates are based on data from the Los Angeles Department of Water and Power (LADWP, 1976) and the Southern California Edison Company (SCE, 1977).

- Total man-hour requirements are estimated assuming 175 man-hours per month and a 24-month construction schedule.

- Materials requirements are based on data developed for the San Joaquin Nuclear Project (LADWP, 1975) and discussions with transmission system engineering personnel of the Los Angeles Department of Water and Power (B. Johnson, 1979):

- Major vehicle and machine requirements are based on the ratio of vehicles/equipment to workforce presented by Southern California Edison in a study of recent transmission system project (SCE, 1977).

- Fuel requirements are based on gasoline/diesel fuel requirements data reported by the Los Angeles Department of Water and Power for a transmission system project (LADWP, 1975).

- Labor cost estimates are based on a $\$ 12$ per hour payroll cost, as presented in a study by United Engineers for the Nuclear Regulatory Commission (UEC, 1977).

- Total costs were estimated based on transmission project data from major southern California utilities (LADWP, 1975; SCE, 1977). 


\subsection{PRESENT ENVIRONMENT}

\subsection{INTRODUCTION}

The Rose Valley/Coso Ground Receiving Station (GRS) study site is located in the southern California portion of the Basin and Range Physiographic Province. This province extends along its western edge from southern Oregon to the Mexico border and eastward to New Mexico (see Figure 3.1-1). It is generally characterized by arid, isolated, roughly parallel north-south trending mountain ranges separated by nearly level desert valleys. The Rose Valley site lies within a corridor composed of several north-south trending basins, the Owens, Rose, and Indian Wells Valleys, which connects the Great Basin to the Upper Mojave Desert region of California.

In general, the GRS study area is typical of physical and natural conditions found throughout the Basin and Range Province. With few exceptions, this is true for climate, hydrology, geology, vegetation and wildlife, mineral resources, soils, water resources, land use, cultural resources, and human settlement patterns.

The topography within the study area ranges in altitude from 1,000 to 1,800 meters above sea level, averaging 1,100 meters at the GRS site. The terrain is uneven, mainly low to medium relief. Present in the area are young alluvial fans, coalesced fans (bajadas), clayfloored playas, saline crusts, seasonally snow covered mountains, and isolated sand dunes of variable form and area. There are several volcanic and hydrothermal features within the GRS site and local vicinity, such as the Red Hill cinder cone (which is within the rectenna field site); located a few kilometers to the east are the Sugarloaf Mountain rhyolite dome, Coso Hot Springs, and the Devil's Kitchen fumarole. The climate is harsh and arid, with extremes of temperature and precipitation from summer to winter. See Figure 3.1-2 for location of geographic features and place names referred to within the GRS study area. Unless otherwise stated, all baseline data presented is derived from the Coso Geothermal Lease Program Draft Environmental Statement (U.S. Department of Interior, Bureau of Land Management, 1980).

\subsection{CLIMATOLOGY}

The climate of the GRS site, typical of the southern California high desert region and much of the Basin and Range province, is characterized by hot summers, cool to cold winters, large diurnal temperature ranges, low humidity, and little cloudiness or visibility restriction.

Precipitation is greatest during the November through April period as a result of cyclonic storm activity and frontal movement from the Pacific. In addition, convective storms, formed by thermal uplift of moist air from the Gulf of California and Gulf of Mexico, provide an irregular period of rainfall from July through September. The Sierra Nevada to the west frequently forms a barrier to passing storms and frontal systems, limiting the average annual precipitation to 8 to 16 centimeters for the GRS study area. The entire region lies within the Sierra Nevada rainshadow.

The mean annual temperature at China Lake (about $40 \mathrm{kilometers} \mathrm{southeast} \mathrm{of}$ the GRS site, at elevation 700 meters) is $18^{\circ} \mathrm{C}$. January has the lowest monthly normal temperature, $6^{\circ} \mathrm{C}$; July has the highest, $30^{\circ} \mathrm{C}$. January also 


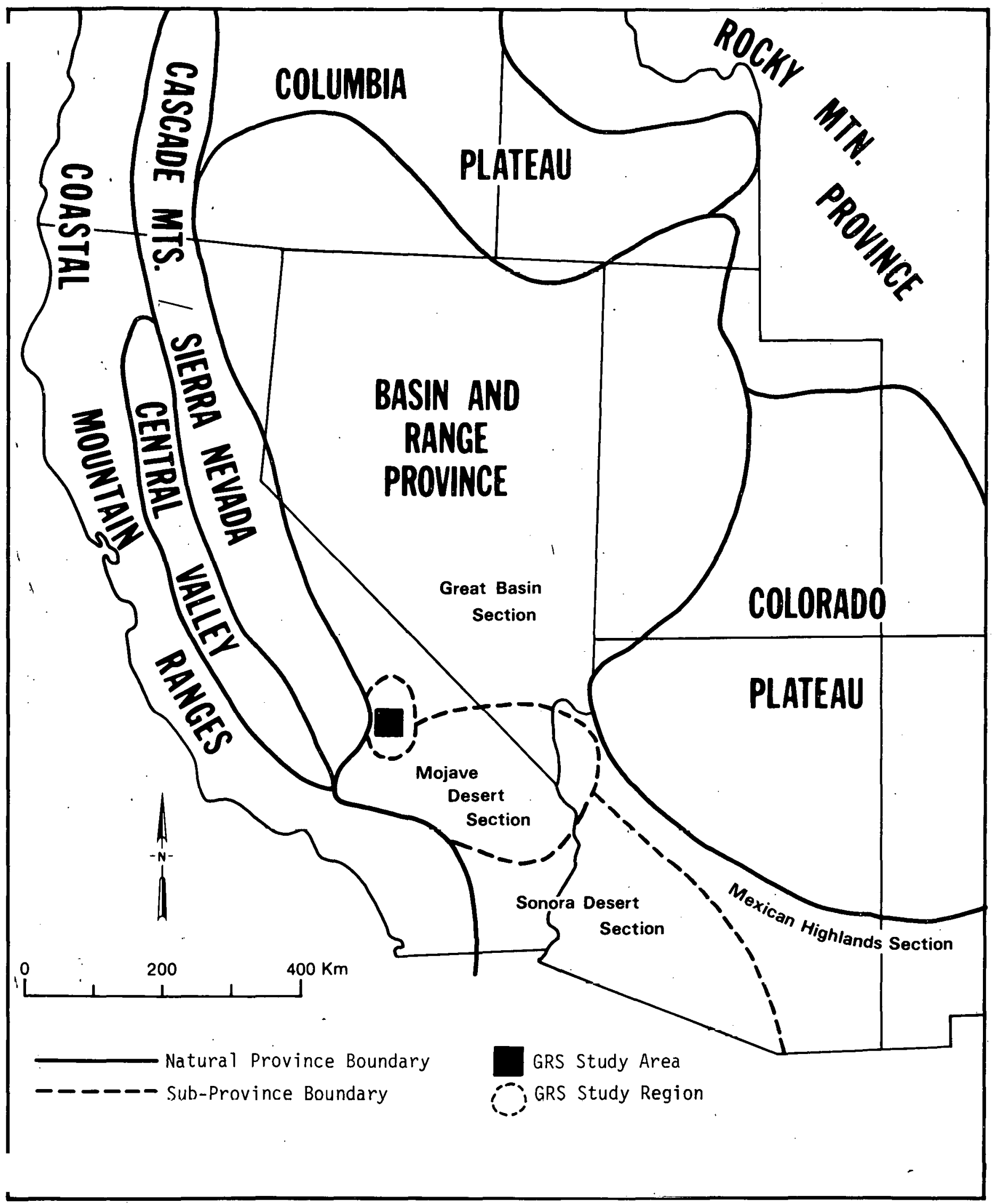

Figure 3.1-1. LOCATION OF GRS STUDY AREA RELATIVE TO NATURAL REGIONS 


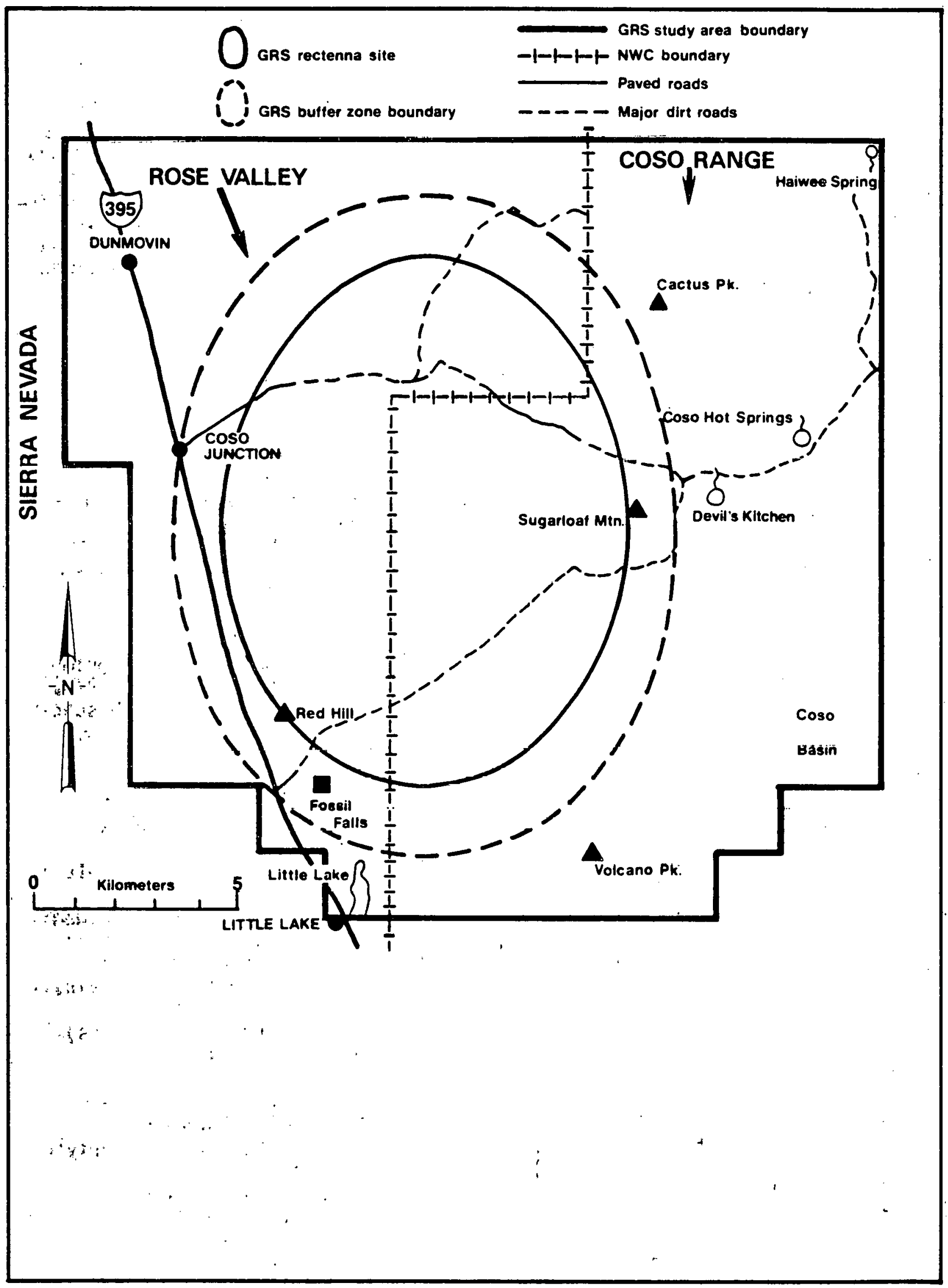

Figure 3.1-2. GRS STUDY AREA AND ASSOCIATED FEATURES 
has the lowest normal daily minimum, $-2^{\circ} \mathrm{C}$, while July has the highest daily maximum, $39^{\circ} \mathrm{C}$. Temperature in the higher elevations of the GRS study area average 3 to $8^{\circ} \mathrm{C}$ cooler than those at China Lake, both for summer and winter.

The north-south orientation of the mountains and valleys in the area influences regional air flow patterns; winds are usually from the south to southeast, or north to northwest. At China Lake the average annual windspeed is $13 \mathrm{kilometers}$ per hour, with the highest monthly average $(17 \mathrm{~km} / \mathrm{hr}$ ) in May and the lowest monthly average $(9 \mathrm{~km} / \mathrm{hr})$ in December. Gusty winds and wind storms are common throughout the winter and spring months. The strongest gust ever recorded was $130 \mathrm{~km} / \mathrm{hr}$ in March, 1952.

\subsection{AIR QUALITY}

Air quality in the study area is quite good, typical of the sparsely populated, nonindustrialized areas of the desert Southwest. There are few manmade emission sources in the area, and the only natural source that distinguishes this area from typical desert is the hydrogen sulfide producing fumarole system in the Devil's Kitchen - Coso Hot Springs area (several kilometers east of the GRS site). A growing problem in recent years throughout the California desert has been the influx of photochemical smog from the Los Angeles and San Joaquin Valley areas, particularly during the summer. months. This problem is still quite rare in the study area, however, because of the distance from major smog-producing areas and because the particular wind conditions required to produce the effect do not occur often.

The China Lake Naval Weapons Center (NWC) staff conducted a monitoring program at several locations in the Rose Valley Coso area from August 1977 to May 1978. They measured carbon dioxide, ozone, hydrogen sulfide, total sulfur, and $B$ scat (visibility), as well as ambient temperature and dew point. The data are summarized in Table 3.3-1, with the sampling periods listed for each site.

The values listed in Table 3.3-1 lie within the range that one would expect for a nonindustrialized desert region. Although a full range of pollutants such as carbon monoxide, nitrogen oxide, and hydrocarbons was not measured during the recent Navy study, ozone is generally considered to be a reasonable indicator of the presence of photochemical smog. The average ozone concentrations were all quite low; only one peak hourly average (Coso Basin) exceeded the old federal one-hour standard of 8 parts per hundred million (pphm) (the new federal standard is $12 \mathrm{pphm}$ ). Thus, photochemical smog appears to be at worst a minor problem in the study area, even adjacent to U.S. 395 at Dunmovin.

The average maximum long-term visibility was 140 kilometers (Coso Hot Springs) in March-April, with a minimum average of 14 kilometers (Coso Basin) in September-0ctober. The three-year average visibility at China Lake was approximately 100 kilometers. Due to the dry climate and sparse vegetative cover of the area, fugitive dust can be a problem for visibility and public health. Major contributors of fugitive dust are vehicle traffic (particularly on the many unpaved roads of the area), other mechanical operations such as road grading and mining, and high winds. During Owens Lake dust storms winds of $80 \mathrm{kph}$ or more blow from the north carrying tremendous quantities of dust over the study area from the dry bed of Owens Lake. These storms can cause the total suspended particulates (TSP) concentration to be well 
Table 3.3-1. SUMMARY OF GRS STUDY AREA AIR QUALITY DATA

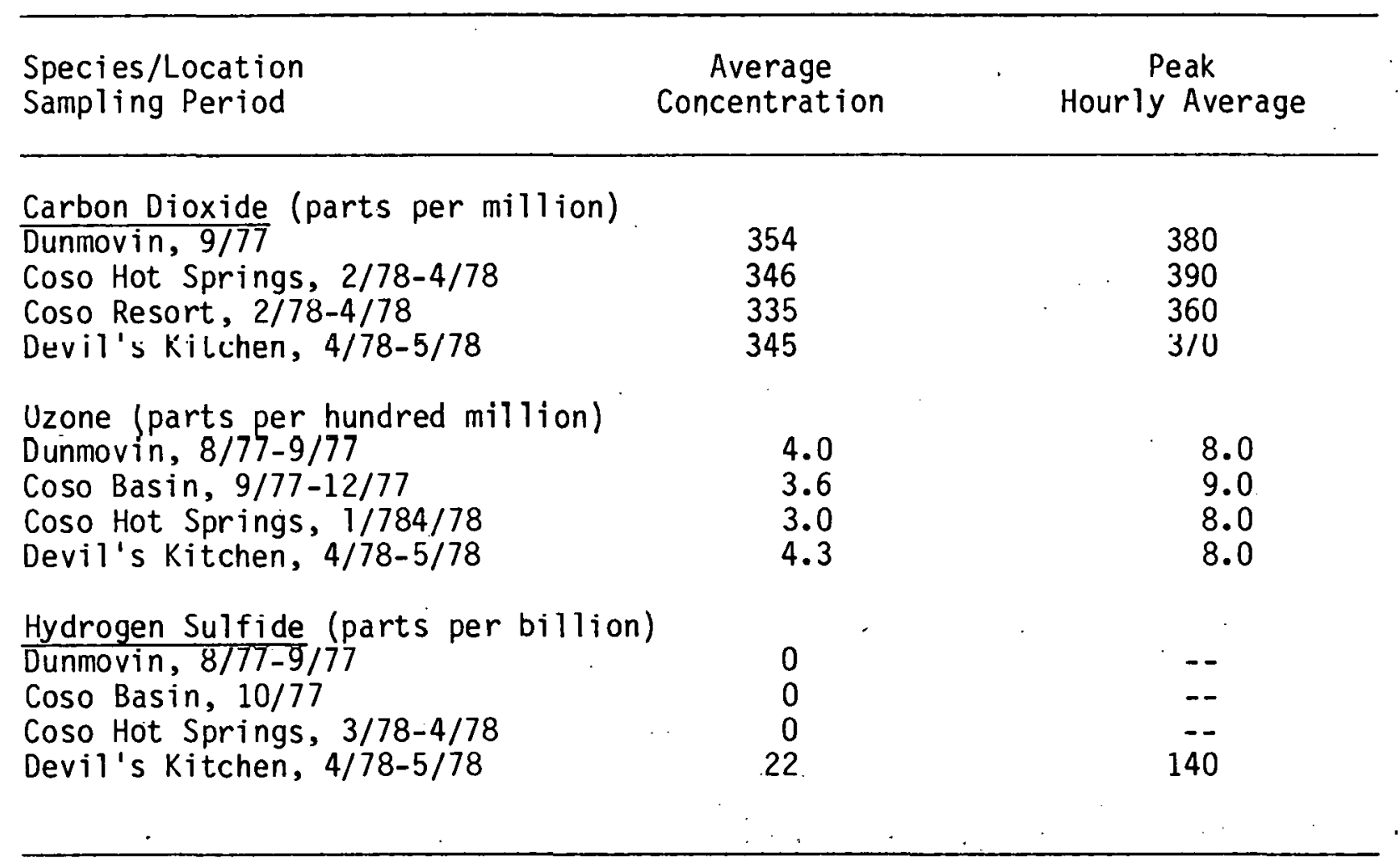


over 1,000 micrograms $/ \mathrm{m}^{3}$ and visibility to decrease to less than two kilometers. The dust can extend over an area as large as 9,000 square kilometers, encompassing both the Coso and Indian Wells Valley areas.

There are several major stationary emission sources (greater than 22.7 tonnes per year emissions) at China Lake, Inyokern, 0lancha, Ridgecrest, and Trona. None of these lie within the boundaries of the GRS site. Mobile sources in the area include traffic on U.S. 395, the Southern Pacific Railroad, and aircraft overflights. Table 3.3-2 lists the total yearly emissions within the entire Rose Valley/Coso study area using standard emission factors. Aircraft emissions have been estimated by assuming that 10 percent of all flights originating at Armitage Field (China Lake NWC) will fly over the study area.

The GRS study site is in the extreme southwestern portion of the Great Basin Valleys Air Basin of California, with the southern (Kern County) portion of the overall study area in the northernmost section of the Southeast Desert Air Basin. For both of these air basins, although the general statement made earlier that local air quality is quite good is considered valid, for a number of air pollutants there are insufficient data to characterize ambient air quality regarding attainment or non-attainment of the National Ambient Air Quality Standards. For both of the applicable air basins, oxidant, carbon monoxide and nitrogen dioxide levels are classified by the Federal government as Classifications " 3 or 4" (Classification 3 means "Cannot be Classified" and Classification 4 means "Better than National Standard"); for particulates and sulfur dioxide the basins "Cannot be Classified" (Ruderman, et al., 1978).

The GRS study area has been designated as a Class II area under the Prevention of Significant Deterioration (PSD) regulations. In Class II areas, moderate deterioration (incremental air pollution) is allowed, in line with somewhat limited growth. It is possible that the area could be reclassified Class I at some future date and only very limited air quality deterioration would then be permitted. The closest Class I areas to the GRS site are the Domeland Wilderness area in Sequoia National Forest, (approximately $30 \mathrm{kilo-}$ meters southwest of the GRS site) and the Golden Trout Wilderness in Inyo National Forest ( $30 \mathrm{kil}$ ometers northwest of the GRS site).

\subsection{NOISE}

The GRS study area is largely a very quiet, undeveloped region. However, there are a number of noise sources which can be considered significant, the greatest constant noise source being U.S. Highway 395. Other man-made noise sources within or adjacent to the study site include several pumice mines immediately north of the GRS site, a cinder mining operation at Red Hill, and an alfalfa ranch located $3 \mathrm{~km}$ northwest of the rectenna site near the abandoned community of Dunmovin. The China Lake Naval Weapons Center contributes both ground-based and airborne noise sources. Military aircraft, small private planes, and helicopters occasionally use the Rose Valley airspace as a north-south flyway. Natural sources, particularly wind, also can make major contributions to ambient noise levels in an undeveloped area such as Coso.

There are few human noise receptors in the GRS area. A few ranchers live along U.S. 395, and there is a small settlement at Little Lake, which includes a hotel 
Table 3.3-2. EMISSION RATES WITHIN THE GRS STUDY AREA (tonnes per year) ${ }^{1}$

\begin{tabular}{lcccc}
\hline Pollutant & $\begin{array}{c}\text { Motor Vehicles } \\
\text { (U.S. 395) }\end{array}$ & Rail road & Aircraft & Total \\
\hline Carbon Monoxide & 365.5 & 0.9 & 68.9 & 435.4 \\
Hydrocarbons & 57.6 & 0.5 & 25.4 & 83.4 \\
Oxtdes of Nitrogen & 98.0 & 1.8 & 34.5 & 134.2 \\
Particulates & 8.2 & -- & 81.6 & 89.8 \\
Sulfur Oxides & 2.7 & -- & 13.6 & 16.3 \\
\hline
\end{tabular}

1. Data is for the entire 30,000-hectare geothermal ES study area, which includes Rose Valley. 
and a gasoline station. There are workers at the mines and ranches in the area, and naval security personnel regularly patrol NWC portions of the study area. Seldom does anyone stay overnight except at the ranches or at Little Lake hotel. An intermittent use area is the Native American prayer site near Devil's Kitchen; Coso Hot Springs is also used periodically for religious observances by Indians, approximately 8-10 times each year. The largest population of human noise receptors in the area consists of travelers along U.S. 395.

Non-human noise receptors are distributed throughout the GRS study area. Indigenous to the area are various birds, reptiles, and mammals. Particularly sensitive to excess noise are raptors (birds of prey), which use the area. Several herds of wild burros and roaming bands of wild horses live in the Coso Mountains (east of the Rose Valley study site), and domesticated farm animals can be found at ranches in Rose Valley. Numerous cattle also range through the area, mainly in winter and spring.

A limited noise monitoring program was conducted in early 1979, at Rose Valley Ranch, just north of the GRS site. The observed noise levels were generally quite low, as one would expect for a largely unpopulated desert area. The average community noise equivalent levels (CNEL) for the Rose Valley Ranch was $58 \mathrm{dBA}$. (An air conditioning unit at a distance of six meters outdoors, measures $60 \mathrm{~dB}$.) The maximum ten minute average noise level recorded at Rose Valley Ranch was $94 \mathrm{dBA}$. (A motorcycle outdoors at a distance of about 7.5 meters measures $90 \mathrm{~dB}$. )

\subsection{GEOLOGY}

This section discusses the geology of the region and of the GRS site and vicinity, as well as seismicity and local mineral resources.

\subsubsection{REGIONAL GEOLOGY}

The GRS site lies al ong the western edge of the Basin and Range structural province of southeastern California, immediately adjacent to the Sierra Nevada province, and just east of the north-south trending Sierra Nevada Fault Zone (see Figure 3.1-1). The GRS site is about 65 kilometers north of the east-west trending Garlock fault zone which forms the boundary between the Mojave Desert and the Great Basin sections of the Basin and Range Province.

The Basin and Range Province is characterized by northerly trending fault block mountains separated by deep alluvial valleys. In general, the ranges are formed from many different types of rocks and range in age from Precambrian to Holocene. Relief within the region is rugged, due primarily to movement on the northerly trending, high angle normal faults which formed the Basin Ranges. Some major Basin and Range fault zones (see Figure 3.5-1) such as the Panamint Valley zone east of the GRS site and the Owens Valley zone to the north have features in common with the San Andreas Fault, e.g., great length and consistent right-lateral offset. The Mojave Desert structural region is characterized by similar features to those outlined for the western Basin and Range Province. 


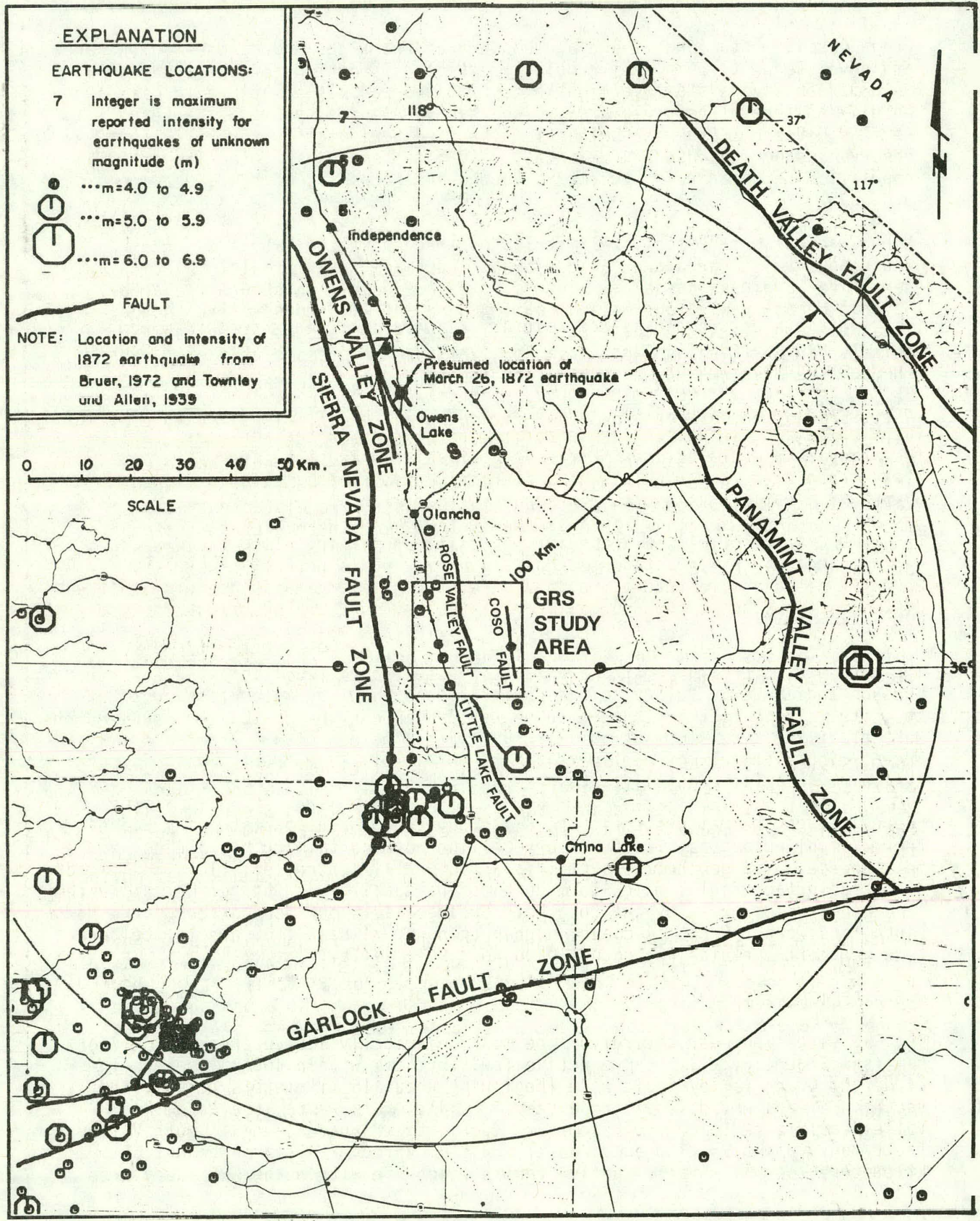

Figure 3.5-1. HISTORICAL SEISMICITY OF THE STUDY REGION 


\subsubsection{LOCAL GEOLOGY}

The topography of the GRS study area is typical of Basin and Range structure, with highest elevations in the north and a gradual southwest slope. The maximum elevation in the GRS study area is 1,810 meters in the northeast corner of the area, about three kilometers northeast of the GRS site. The GRS site in Rose Valley has a minimum elevation of about 1,000 meters at the southern end of the valley.

The Coso Range, located along and parallel to the eastern side of Rose Valley, is composed of basement igneous and metamorphic formations, overlain with later (and recent) volcanic flows and unconsolidated sedimentary material. Rose Valley contains a series of alluvial fans and coalesced fans (bajadas) which originate in both the Coso Range and the Sierra Nevada. The valley floor consists of unconsolidated alluvium, mineralized playa deposits, and aeolian (wind) deposited materials, mainly sand. Some volcanic cinder cover is also present.

The Coso Range is extensively faulted and contains several active fault systems. The high degree of faulting and shearing can be seen in the southeast part of the study area where basement rocks are pervasively fractured and occur as small blocks, about one meter on a side. The most conspicuous active fault near the GRS study area is the Coso Hot Springs fault zone about 5 to 7 kilometers east of the GRS site. A highly dissected older fan on the west side of the coso Range in Rose Valley is an indicator of uplift continuing along the west part of the range. Gravity data show that alluvium in this part of the valley abruptly deepens more than a thousand meters. This large displacement and the dissected fan suggest that normal frontal faults bound the southwestern coso Range.

The northwest trending Little Lake fault can be traced from Little Lake south through Indian Wells Valley to the Garlock fault about 65 kilometers south of the site. It is part of the Sierra Nevada fault zone which also continues northward along the east slope of the Sierra Nevada. It exhibits indications of recent right-lateral movement with almost no dip-slip component, which is more typical of Pacific coastal faults.

There is a geothermal system in the GRS study area which consists of surface thermal manifestations, fractured crystalline rock containing hot fluids, and a heat source. The genthermal system is structurally controlled; fluid is "piped" along subsurface faults which form zones of permeability. The geothermal system is bounded on the east by the coso Hot springs fault but boundaries on the north, south, and west are not as clear; higher than normal heat flow and low temperature geothermal fluids are found throughout Rose Valley.

\subsubsection{SEISMICITY}

The GRS site lies near several of the most seismically active areas of California (see Figure 3.5-1). Large active fault systems within $160 \mathrm{kilometers} \mathrm{in-}$ clude the Owens Valley fault zone (beginning about 16 kilometers north), the southern Sierra Nevada fault zone (about $5 \mathrm{kilometers} \mathrm{west),} \mathrm{the} \mathrm{Panamint}$ Valley fault zone (about 50 kilometers east); the Furnace Creek - Death Valley fault zone (about 95 kilometers east) and the Garlock fault zone (about 65 kilometers south). Smaller active faults which lie within the GRS study area 
include the Haiwee Spring - Coso Hot Springs - Airport Lake fault zone (along a north-south axis 5 kilometers east of the GRS site) and the Little Lake fault (along a north-south axis immediately to the west of the GRS site)..

The southern Sierra Nevada and its surrounding area is characterized by a high level of strain release, microseismic activity and generation of several large to moderate magnitude earthquakes. More than 10 events of Richter magnitude 5 to 5.9, two of magnitude 6 to 6.9 and one of magnitude $8+$ have occurred within $100 \mathrm{kilometers}$ of the study area since 1872 (see Figure 3.5-1). The areas of highest seismicity within a 100-kilometer radius occur in Owens Valley and along the Sierra Front southwest of Little Lake. The great 1872 earthquake and another large reported earthquake in 1790 were located in Owens Valley. A series of magnitude 5 to 6 earthquakes occurred southwest of Little Lake in. 1946.

The nwens Valley earthquake of 1872 is generally regarded as the largest shock in California history. The earthquake has been assigned a Modified Mercal 17 intensity of $X-I X$ arid inagnitude greater than 8 . Damage to the adnbe-built communities in the Owens Valley was total and at least 60 deaths were attributed to the shock. Vertical displacement of up to seven meters occurred; horizontal displacement was up to six meters. Surface rupture along the fault extended for over 160 kilometers from Haiwee Reservoir north to Big Pine.

The Rose Valley/Coso area is also an area of high microseismic activity, occurring in swarm-type sequences and with relatively shallow hypocenters. Seismic activity as high as over 100 events per day was recorded in a recent two year study. No mappable surface faults were correlated with this microseismic activity, however.

\subsubsection{Mineral Resources}

Mineral resources of the GRS study area include low-grade mercury and sulfur deposits, cinders, granitic rock for building stone, adobe, and extensive undeveloped deposits of sand and gravel. Uranium, traces of copper and possibly tungsten have also been found in the vicinity. Tuff and pumice have been commercially mined from the Coso Mountains for many years from sites a few kilometers north and northwest of the GRS study area. Minor production of mercury and sulfur occurred at the Devil's'Kitchen area (several kilometers east of the GRS site) in the early part of the 20th Century. However, an extensive exploration of the mercury deposits in 1948 revealed no commercial concentrations of ore. Commercial mining of cinders at Red Hill is the only known mining in progress within the GRS site.

3.6 SOILS

The soils of the GRS site are typical of Great Basin and Mojave Desert valley solls. Valley bottoms generally feature clayey and silty soils, tending to be saline or alkaline. Away from the valley bottoms, soils are more coarse and well drained, and are sandy to stony. Calcareous (chalky) hardpans (hard impervious layers) below the surface are common features. The soils of the GRS site and vicinity are mapped in Figure 3.6-1. The mapping units will be described in this section. 


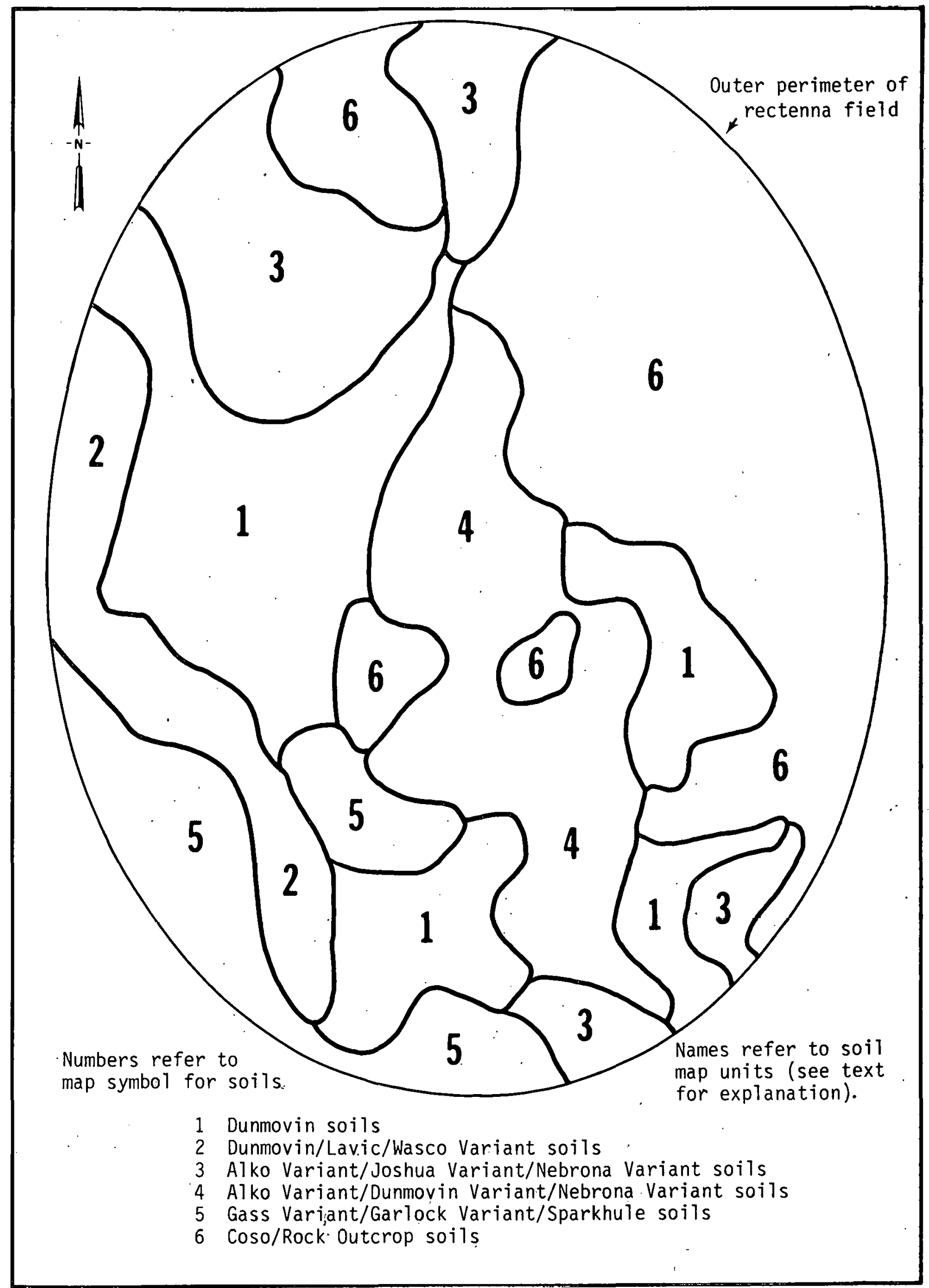

Figure 3.6-1. GRS SITE SOIL MAP UNITS 
Map Unit 1. Dunmovin Soils - deep, nearly level to moderately sloping, somewnat excessively drained sandy soils; formed in alluvium. This map unit is found on al luvial fans and plains of Rose Valley. Slope ranges from zero to 9 percent. The profile consists of loamy sands throughout, with some areas having bouldery surfaces. The soil is commonly calcareous below a depth of about 70 centimeters. This soil is suited for highly drought-resistant irrigated crops and forage plants; low available water capacity, sandy surface texture, and the hazard of soil blowing are the main limitations.

Map Unit 2. Dunmovin/Lavic/Wasco Variant Soils - very deep, nearly level, somewhat excessively to well-drained sandy and loamy soils; formed in alluvium. This map unit consists of soils on lower valley floors and interplaya dunes and flats of Rose Valley. It is about 32 percent Wasco Variant soils, 30 percent Lavic soils, and 21 percent Dunmovin soils, with the remaining 17 percent minor soils. These soils generally feature loamy sands, are well drained, and are moderately to strongly alkaline. However, the minor areas are the very poorly drained, nearly level playas in valley basins and the excessively drained areas of riverwash along ephemeral stream courses. Areas of this unit are used as a source of sand and gravel, but the hazard of soil blowing is a limitation to this use. Playa areas are subject to periodic ponding, and ephemeral streams are subject to periodic overflow.

Map Unit 3. Alko Variant/Joshua Variant/Nebona Variant Soils - very shallow to deep, gentiy sloping to moderately steep, well-drained, cobbly sandy soils with hardpans; formed in alluvium. This map unit is on strongly dissected older alluvial fans and terraces in Rose Valley. It is about 25 percent Nebona Variant soils, 25 percent Alko Variant soils, 15 percent Joshua Variant soils, with the remaining 35 percent minor soils. Areas of this unit can be used for rangeland, but the major limitations for this use include limited rooting depth, stones, cobbles, and gravel on the surface, and the hazard of soil blowing. These limitations affect the production of forage suitable for livestock grazing.

Map Unit 4. Alko Variant/Dunmovin Variant/Nebona Variant Soils - very shallow to deep, gently to moderately sloping, somewhat excessively to well-drained soils with hardpans; formed in alluvium. This map unit occurs on slightly dissected, somewhat older alluvial fans of the eastern portion of Rose Valley. It is about 50 percent Dunmovin Variant soils, 20 percent Alko Variant soils, and 20 percent Nebona Variant soils, with the remaining 10 percent minor soils. This unit can be used for rangeland, but the sandy surface textures, dryness, and hazard of soil blowing are the main limitations on the Dunmovin Variant soil. Limited rooting depth and the cobbly surface on the shallow soils also affect the use of this unit for rangeland.

Map Unit 5. Gass Variant/Garlock Variant/Sparkhule Soils - shallow to moderately deep, moderately sloping to moderately steep, well-drained, cobbly sandy and loamy soils; formed in basalt and cinders. This map unit occurs on upland mesa basalt flows and cinder cones, generally in the southern portion of Rose Valley. This unit can be used for rangeland and areas of this unit are used as a source of cinders. This unit is limited for many uses due to rock outcrops, stones, cobbles, and gravel on the surface. The high salt content of the Gass Variant soil limits the area to more salt-tolerant plants.

Map Unit 6. Coso/Rock Outcrop Soils - very shallow to shallow, moderately steep to steep, somewhat excessively drained stony loamy soils; formed in 
granite; and igneous rock outcrops. This map unit is located along the eastern side of the GRS site and develops from the granitic uplands of the Coso Range. It is about 31 percent Coso soils, 30 percent rock outcrop, with the remaining percentage minor soils. Rock outcrops limit access to and use of this unit.

\subsection{HYDROLOGY/WATER QUALITY}

This section describes the existing hydrologic environment, in terms of surface water, ground water, hydrologic balance and water use and availability for the GRS site and vicinity. This hydrologic regime is typical of that found elsewhere within the Basin and Range Province.

\subsubsection{SURFACE WATER}

In this subsection, the surface water hydrology will be described in terms of watershed features, runoff, water quality, and erosional attributes.

\subsubsection{Watershed Features}

Soils and vegetation are significant factors contributing to the high runoff potential of upland watershed areas of Rose Valley. The principal runoff producing areas in the area are the upland areas of the Sierra Nevada and the Coso Range. These areas are characterized by shallow soils and exposed bedrock with relatively high runoff potential. The sparse brush vegetation found in these areas also enhances the runoff potential of the upland watershed. However, the soils and vegetation of the study area are capable of retaining the moisture from most low-intensity precipitation events.

Surface water flow in the study area is characterized by predominantly ephemeral stream flow. Minor amounts of perennial streamflow exist in the Sierra Nevada in response to snowmelt at the upper elevations. The ephemeral nature of surface water flow is primarily a function of the very low frequency of heavy precipitation. Surface runoff that does not infiltrate generally reaches playas or depressions where it is lost to evapotranspiration. Voluminous short-term runoff occurs mainly in large steep sided washes of less permeable materials.

Rose Valley drains southward toward the upper part of Indian Wells Valley at Little Lake. Perennial and ephemeral streams originating in the'Sierra Nevada and ephemeral streams originating in the Coso range drain toward the floor of Rose Valley. Most of the water infiltrates into the alluvial fans or is trapped in small playas and depressions before reaching Little Lake. The perennial streams terminate before reaching the valley floor. Several small perennial and ephemeral springs discharge at the base of the Sierra Nevada.

Little Lake, an emergent underflow lake, is the only perennial surface water body in Rose Valley. There is minimal perennial surface discharge from Little Lake into Indian Wells Valley. It is a flat-bottomed spring-fed lake with an area of about 400 hectares, and an average depth of slightly more than one meter. When its level is low, two wells pump water into it. Little Lake is a remnant of the pluvial (rain-caused) Owens River channel, and was only a marshy area unt il. a dam was constructed in the 1920s. Haiwee Reservoir (8 kilometers northwest of the GRS site) is an artificial storage reservoir, part of the Los Angeles Aqueduct System, and is scheduled for decommissioning in the early 1980s. 
The GRS site and vicinity is arid to semiarid, characteristic of the entire Basin and Range Province. Under these climatic conditions, surface flow occurs on a relatively rare basis. In most years, surface water runoff may occur only several times. Only in years of unusually high precipitation will streams flow onto the valley floors all year. The annual runoff in the CGSA is dependent on the temporal and spatial distribution of precipitation throughout the year. About 70 percent of the average annual precipitation occurs between November and March. During this period, the precipitation is characterized by gentle rains and occasional snow, which results in a minimal contribution to annual runoff. However, during late summer and early fall, convective storms can produce high runoff volumes disproportionate with the precipitation amounts occurring during the storms because of their intensity. Estimates of average annual runoff are presented in Table 3.7-1.

Event-based analysis is generally used to pinpoint the effects of extreme hydrologic occurrences, such as that occasionally characteristic of the study area; analysis of extreme flood conditions is essential to the overall hydrologic evaluation of the GRS site and vicinity. The 100-year design storm was chosen for analysis as the extreme precipitation occurrence for each of the storm types occurring at the GRS and vicinity. The 100-year 24-hour storm is representative of extreme frontal activity, and the 100-year 6hour storm is representative of extreme convective activity. Estimates of surface runoff and peak discharge are shown in Table 3.7-2.

\subsubsection{Surface Water Quality}

The quality of surface water in the GRS site and vicinity is influenced by the type of runoff generated by precipitation events. The chemical quality of runoff from frontal events (not infrequent in Coso, but also not very powerful) probably varies little from that of convective events (less common than frontal storms in Coso, but quite intense when they occur). The principal difference in water quality resulting from frontal and convective storms is suspended sediment. Frontal storm runoff generally produces minor channel and upland erosion, whereas convective storm runoff produces significantly greater channel and upland erosion and would therefore have a higher suspended sediment content. Water quality data are difficult to obtain due to the infrequency of runoff events in the study area. Chemical analyses are presented in Table 3.7-3 for Portuguese Canyon (to the west of the GRS site) and Little Lake, respectively.

\subsubsection{Erosion}

Major runoff events can mobilize large amounts of sediment, particularly on steep slopes. In the GRS study area, sheet erosion and wind erosion produce only minor sediment yields relative to channel erosion. The soils in the area are fairly stable and not susceptible to significant amounts of sheet erosion. Channel erosion and sediment transport are governed by the amount and duration of runoff and degree of channel development. Frontal storms with associated convective activity produce long-duration high flows, necessary for maximum sediment transport. Infrequent storms of this nature are not unusual during late summer months. The amount of runoff and subsequent erosion are greatly reduced by infiltration to the stream bed. The porous materials in the stream beds in the area are capable of sustaining large stream bed losses during runoff periods. Wind erosion is most prevalent during the non-vegetative period of the year (October to May). The wind-eroded materials are generally deposited in stream channels, which further increases the potential for stream 
Table 3.7-1. AVERAGE ANNUAL PRECIPITATION AND RUNOFF IN THE GRS STUDY AREA

$\begin{array}{ccc}\text { Area of } & \text { Average } & \text { Average } \\ \text { Watershed } & \text { Annual } & \text { Annual } \\ \text { (sq. km) } & \begin{array}{c}\text { Precipitation } \\ \text { (centimeters) }\end{array} & \text { Runoff } \\ & \text { (centimeters) }\end{array}$

$\begin{array}{lccr}\text { Rose Valley } & 420 & 19-20 & 5 \\ \text { Upper Cactus Flat } & 40 & 21 & 5 \\ \text { ( } 5 \text { km northeast of } & & & \\ \text { GRS site) } & & \end{array}$


Table 3.7-2. CHEMICAL ANALYSES FOR TYPICAL STUDY AREA WATERS

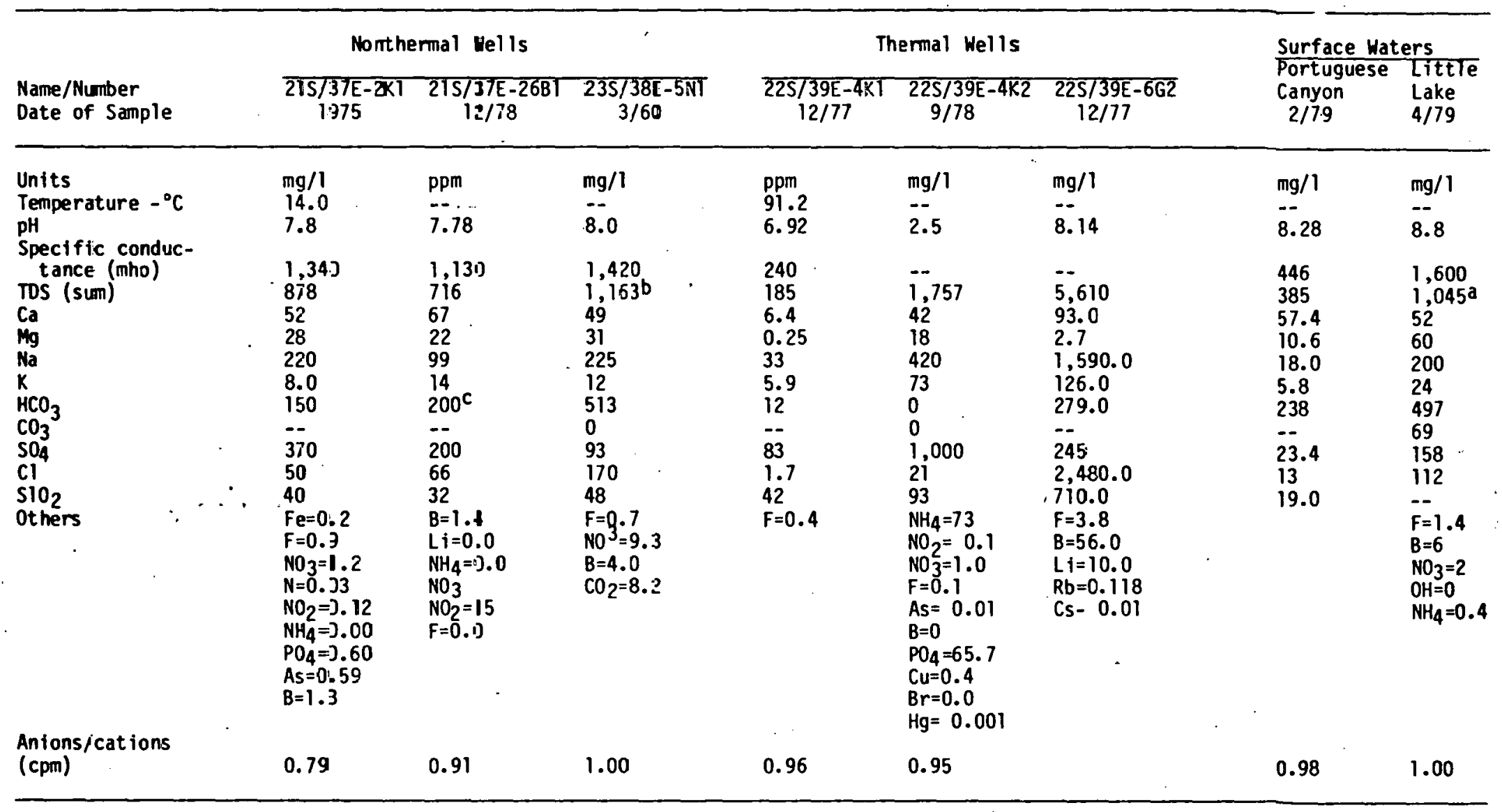

a. TSS residue on evaporation at $180^{\circ} \mathrm{C}$.

b. Recalculated from original saurce.

c. Value is for $\mathrm{HCO}_{3}+\mathrm{CO}_{3}$ - 
Table 3.7-3. " ESTIMATES OF RUNOFF FROM WATERSHEDS IN THE GRS VICINITY FOR THE 100-YEAR DESIGN STORMS

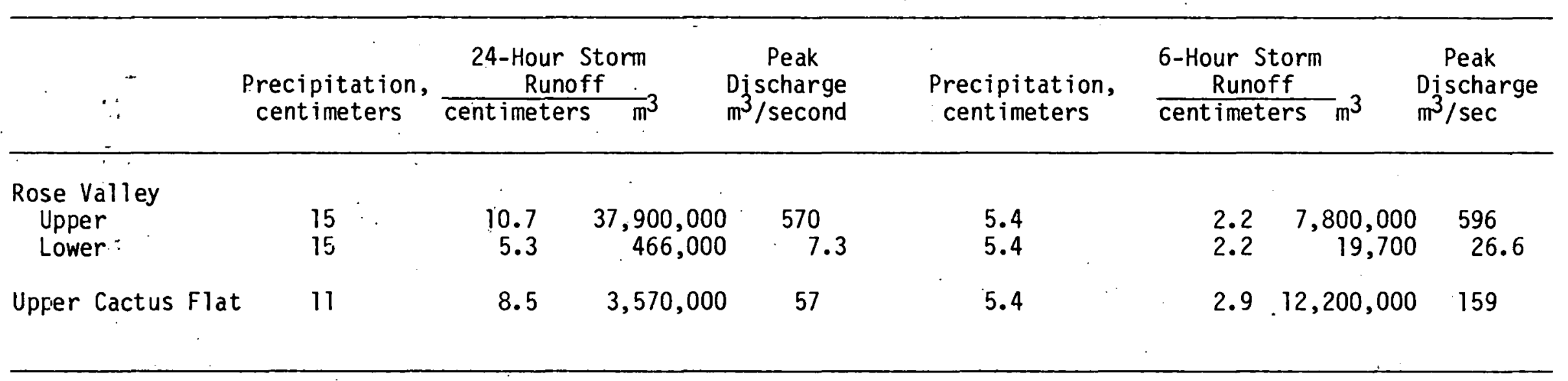


channel erosion. Although average annual values are not large, individual storms can produce large quantities of sediment in stream channels and playas in the GRS vicinity. The annual sediment yield is moderated by the infrequent occurrence of large convective storms which produce the high sediment yields.

\subsubsection{GROUNDWATER}

The groundwater aspects of the hydrology of the GRS site and vicinity are outlined in this section. It includes discussion of water-bearing hydrologic units and their location, and groundwater movement.

Quaternary alluvial sediments comprise the principal water-bearing unit in the area. It consists mainly of alluvial fan and stream deposits. The deposits are irregularly bedded and consist of a heterogeneous mixture of unconsolidated clay, silt, sand, gravel and boulders. The alluvium in the central and west portion of Rose Valley is composed of finer and better sorted debris than the fans which apron the Sierra front. These units have a wide range of permeability depending on the degree of sorting and grain size in each specific local ity.

Production for any given water well is generally proportional to the quantity of coarse, well sorted material penetrated beneath the water table. Any properly constructed well in the central alluvial area of Rose Valley could be expected to yield moderate to very large quantities of water. Some wells in the al luvium of Indian Wells Valley yield more than 16,000 liters per minute. The fans are not as consistently good aquifers as the more central alluvial sections of Rose Valley. Thickness of the Rose Valley alluvium has been estimated at up to 1,500 meters, but additional gravity data may reduce the estimate for maximum thickness by about half. The older alluvium which occurs in the northeastern portion of Rose Valley (mainly within the GRS site), also is a waterbearing unit.

Very little water level data are available for the Rose Valley/risn area. However, compilation, interpretation and extrapolation of all data suggests that the major component of ground water flow into Rose Val ley is from west to east from the Sierra Nevada, and the Sierra Nevada fault zone apparently acts as a ground water barrier. The configuration of schematic ground water contours implies an east to west component of flow from the Coso range into Rose Valley. If this is true, then there is hydraulic connection between the geothermal reservoir and the ground water in Rose Valley. Alternatively, a groundwater barrier may prevent flow between Rose Valley and the genthermal resevoir. Presently there is not enough water level elevation data to determine which of these interpretations is correct.

\subsubsection{WATER CHEMISTRY AND QUUALITY}

Interpretation of water chemistry data for wells, springs, and surface waters within the Rose Valley/Coso area suggests that there are three fairly distinct types of "parent" waters. These three types are calcium carbonate water derived from surface runoff from the mountains, sodium chloride water which is found in the geothermal reservoir, and sodium sulfate water which is typically found in the surface thermal manifestations in the Coso Range. Other waters in the study area can be viewed as mixtures of these basic types undergoing various chemical reactions. Comparison of chemical characteristics of waters can suggest genetic and other relationships between different waters. 
Most known ground and surface water in the area appears suitable for domestic, agricultural and livestock use, except for the thermal waters and the somewhat more mineralized waters in the Little Lake area. There are presently no chemical data for water on the east side of Rose Valley or at depth. These data are necessary to define baseline conditions. In addition to spatial variation the chemical composition of natural waters will vary with time.

The spring and surface waters from the Sierra and the Coso Range are calcium carbonate in character. They generally contain about 300 to more than 500 milligrams per liter TDS (total: disolved solids). The TDS of this type of water in the ground is generally somewhat greater than that in the surface runoff due to some evaporative concentration and solution of minerals.

Wells and surface water in the Little Lake area have TDS contents up to more than 1,300 milligrams per liter. A boron concentration of $6 \mathrm{mg} / \mathrm{L}$ for the surface water makes its totally unsuitable for agricultural applications. See Table 3.7-3 for data on water chemistry of wells and surface waters at or near the GRS site.

\subsubsection{HYDROLOGIC BALANCE}

The hydrologic balance is a tally of all water entering and leaving a specified drainage area. In order to maintain water resources, the amount of water entering the area must equal the amount of water leaving. If more water enters than leaves, then water in storage is reduced. Calculation of the hydrologic balance will allow estimation of the practical sustained yield, i.e., the amount of water that may be withdrawn from the system without producing undesirable effects. The practical sustained annual yield may exceed the mean annual recharge, particularly in arid regions where there may be large volumes of ground water in storage.

In the GRS study area, there has been so little water use and so few wells drilled that, at best, the parameters necessary for a hydrologic balance must be rough estimates. A summary of the hydrologic balance for Rose Valley is presented in Table 3.7-4. Within the roughness of the estimates, the Rose Valley ground water basin presently appears to be near hydrologic equilibrium with a ground water recharge of 4.3 to 5.7 million cubic meters and a discharge of 5.0 to 5.8 million cubic meters. Ground water excess or deficiency is not more than several hundred acre-feet per year. This balance may be modified by further studies which would confirm the assumptions these estimates are based on; including: assumptions regarding precipitation on the east slope of the Sierra, the precipitation/potential ground water recharge relation, and the recharge from areas to the north.

Ground water in storage for Rose Valley has been estimated by assuming an average specific yield for the saturated thickness of alluvial material in the valley. Assuming an unconfined aquifer with a 10 to 15 percent specific yield, the total volume of water in storage is 4.0 to 6.2 million cubic meters. of this total, 1.7 to 2.7 billion cubic meters are within 300 meters of the surface. Most of the water in storage is believed to be usable but the geothermal reservoir fluid may extend into the alluvial material on the east side of the valley or saline water may occur in other locations. 
Table 3.7-4. ESTIMATED HYDROLOGIC BALANCE FOR ROSE VALLEY

Quantity

(000 cubic meters/year)

Recharge

Precipitation

Surface inflow

Subsurface inflow

Imported water

$$
\begin{gathered}
69,000 \text { to } 74,000 \\
0 \\
710^{1} \\
370 \\
\hline 70,000 \text { to } 75,000
\end{gathered}
$$

Discharge

Evaporation and transpiration

Surface outflow

Subsurface outflow

Exported water

$$
\begin{gathered}
69,000 \text { to } 75,000 \\
0 \\
55 \text { to } 615 \\
0 \\
\hline 69,000 \text { to } 76,000
\end{gathered}
$$

Assumption: No hydraulic connection with the geothermal reservoir

1. Additional subsurface inflow may originate in the northern part of Haiwee Reservoir and flow through the alluvial fans west of the reservoir and then into Rose Valley. 


\subsubsection{WATER AVAILABILITY AND USE}

No surface water is available for use in or near the GRS site. All water used comes from the pumping of local groundwater. Current water use is quite limited in Rose Valley; Rose Valley Ranch is the major water user, pumping about 3.8 million cubic meters/year. Domestic use is small due to the low population. Water use in Rose Valley is summarized in Table 3.7-5.

Water rights and water reservation agreements or disputes between federal, state, and local government agencies as well as Native American groups and private land owners or lessees create complications for future development. For example, as a result of a 1933 Executive Order issued at the behest of the Los Angeles Department of Water and Power (LADWP), the U.S. Bureau of Land Management (BLM) has designated most BLM-owned land in Rose Valley as a "protective water withdrawal," segregating it from any use other than recreation, grazing, wildlife or non-metalliferous mining. However, a recent BLM-LADWP agreement would also allow water extraction in Rose Valley for geothermal development.

Another legal constraint involves the potential effects of ground water withdrawal on subsurface inflow from adjacent basins and subsurface outflow to adjacent basins. For example, residents of Indian Wells Valley have already expressed concern that ground water withdrawal in Rose Valley may reduce the contribution of underflow from Rose Valley southward into Indian Wells Valley. Such water supply and use problems are common to most of the Range and Basin Province and become particularly acute in a arid and semiarid sections like the Great Basin and Mojave Desert, imposing severe constraints on any water-use development projects.

\subsection{FLORA}

The GRS study site is located in high, or cold, desert in an area of the Basin and Range Province transitional between the Mojave Desert ecosystems to the south and the Great Basin ecosystems to the north. The Sierra Nevadas on the west create a rain-shadow effect over the area and the region in general; annual precipitation ranges from 8 to 16 centimeters. The major portion of the GRS site and vicinity is composed of the broad and fairly level Rose Valley, while the northern and eastern edges comprise a part of the Coso Range. Here the terrain is complex with locally strong relief and numerous washes and sinks or depressions (areas of internal drainage). Soils also are varied, ranging from fine-particled types in lowlying basins to decomposed granitic and coarse alluvial types and cinder deposits on slopes and upland areas. Two freshwater habitats, Little Lake (just south of the GRS buffer zone) and Haiwee Spring (more than five kilometers and across a mountain range from the GRS and hence beyond the zone of GRS impact) comprise the only perennial freshwater sources in the vicinity; several ephemeral playa lakes and numerous washes become temporary water sources after storms.

These variables combine to form a complex vegetative pattern in which the classic plant communities of the Mojave Desert and the Great Basin grade into each other, with a variety of subdominant species present (for example, Creosotebush Scrub may occur mixed with Shadscale Scrub). Also, in numerous sinks and basins, cold alr drainage produces microclimate conditions where plants adapted to the northern Great Basin desert are found, while surrounding vegetation may be a mixture of Mojave Désert species. Therefore, floral diversity in 
Table 3.7-5. ESTIMATED WATER USE IN ROSE VALLEY

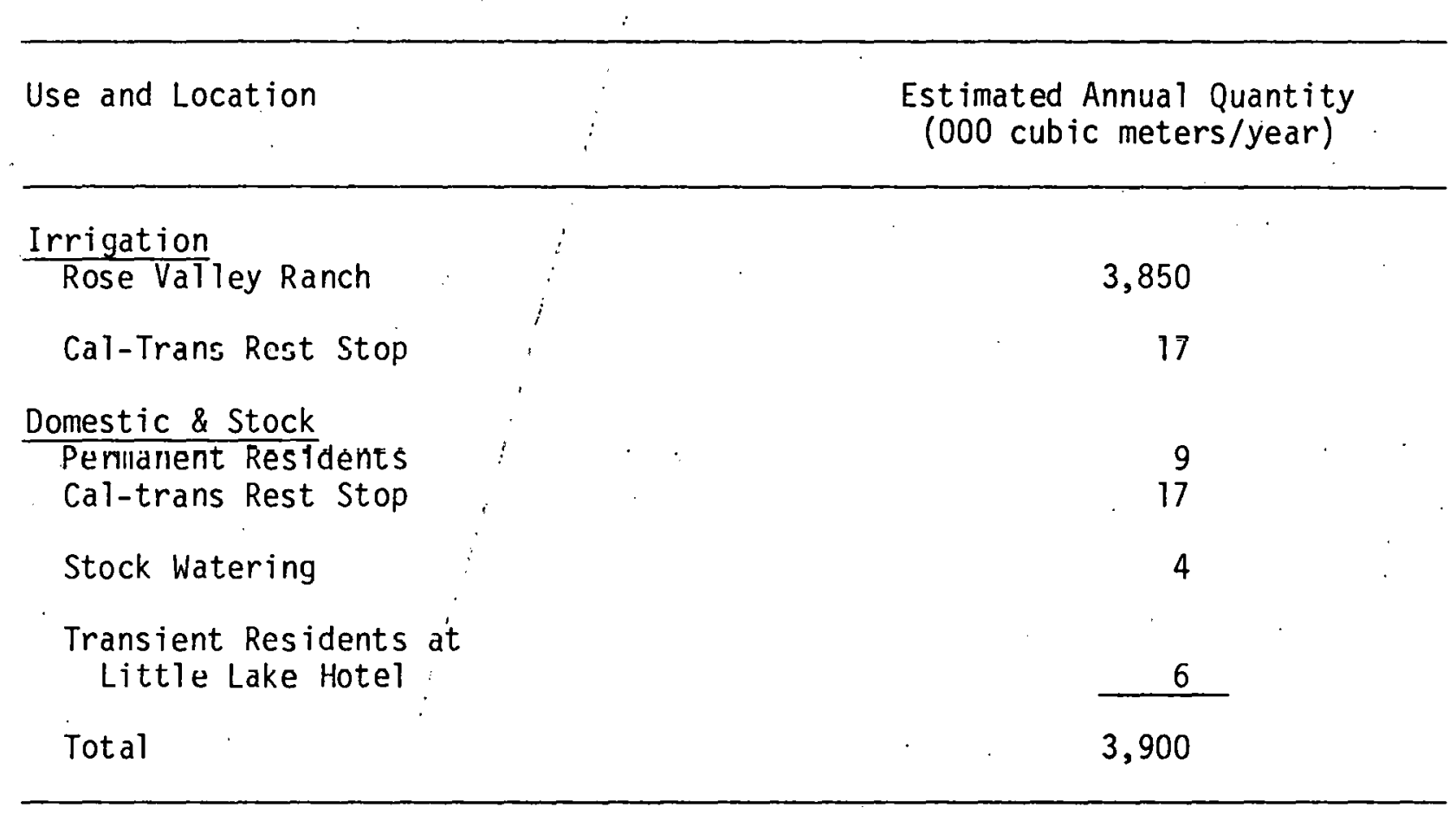


Rose Valley is greater than in areas located exclusively within either the Mojave or Great Basin desert ecosystems. In the following description, study area vegetation is grouped by major dominant species and associated subdominant plants. Cultivated, disturbed, and barren areas are described and then a summary of sensitive floral areas is presented, as well as a discussion of rare plants and those of limited distribution.

\subsubsection{DOMINANT COMPONENT PLANT SPECIES/ASSOCIATIONS}

Creosote Bush - Larrea tridentata is a very common plant throughout the Mojave Desert, actually occurring over about 70 percent of its total area. In the Rose Valley, creosote bush occurs mainly with burro weed (Ambrosia dumosa), and numerous other subdominant species; the resulting plant association is approximately equivalent to the Creosotebush Scrub Community described by Munz (Munz, 1974). It is present on the slopes of the Sierra Nevada west of the GRS site and on the east side of Rose Valley up to an elevation of about 1,200 meters.

Burro Weed - Ambrosia dumosa is a dominant understory component mainly on coarse, sandy soils bordering Rose Valley. Normally it is associated with creosote bush.

Shadscale - Atriplex confertifolia is common in depressions as well as larger basins of the GRS site and vicinity. Much of the floor of Rose Valley is made up of this species. The most commonly associated plants include cheesebush (Hymenoclea salsola), ricegrass (Oryzops is hymenoides), box-thorn (Lycium andersoni), and bud sagebrush (see below). This plant association is comparable to the Shadscale Scrub Community described by Munz.

Bud Sagebrush - Artemisia spinescens is commonly associated with shadscale and together they constitute the major plants in the Shadscale Scrub Community. In the GRS vicinity, bud sagebrush is found usually with shadscale on the lower flat areas and basins; in some areas it occurs alone.

Additional plant species and associations which may predominate in smaller areas of the GRS and vicinity are allscale, four-winged saltbush, Joshua Tree, the mixed desert scrub association, and the alkali sink brush association. Allscale (Atriplex polycarpa) is dominant in certain sandy arroyos where it occurs with cheesebrush and in clay sink areas of Rose Valley. Four-winged saltbush (Atriplex canescens) is generally found either alone or with allscale in clay soil depressions in the area at elevations between 1,200 and 1,500 meters. The Joshua Tree (Yucca brevifolia), the most distinctive plant in the Mojave Desert, is found primarily in scattered locations throughout the eastern sections of Rose Valley and also in a number of small areas between Volcano Peak and Sugarloaf Mountain. At elevations above 1,200 meters, the Cresosotebush Scrub association is replaced by a broad mosaic of species, the Mixed Desert Scrub association, which is more characteristic of the Great Basin desert to the north and east. The Alkali Sink Brush association occurs around dry lake beds or playas and around Little Lake and features various genera of rushes and sedges (e.g. Scirpus, Carex, Juncus).

\subsubsection{CULTIVATED, DISTURBED, AND BARREN AREAS}

In addition to the dominant plants and associated species mentioned above, there are several areas within Rose Valley that are devoid of a natural overstory of vegetation. These include: 
Cropland - Alfalfa is grown on approximately 160 hectares of irrigated land.

Disturbed areas - Gravel, cinder and pumice mining sites in the GRS vicinity are in a state of recovering from past disturbances: here some native vegetation (frequently allscale, shadscale, and cheesebush) is recolonizing, but a number of introduced weedy species such as Russian thistle and sandbur are also noted. At the rest stop at Coso Junction, buildings, irrigated grasses and a stand of over 20 good-sized poplars are present. Other buildings, such as at the Rose Valley Ranch, Lewis Ranch, and those west of Coso Junction are surrounded by disturbed areas; introduced species include Italian Cypress, cottonwood, locuśt, tamarisk, willow, sycamore, and maple. Other human uses, such as borrow pits, roads, aqueducts, railroads and sidings, have resulted in similar disturbances and creation of artificial barrens. See Section 3.10 (Land Use) for details.

Several barren areas or playas have developed along the central drainage of Rose Valley. These areas contain shallows after winter rains and usuaily these have a clay surface which cracks when dry. At the periphery of each of these is often a growth of allscale, but the playas themselves are usually barren of any vegetative cover.

\subsubsection{SUMMARY OF SENSITIVE FLORAL AREAS}

Although the GRS site appears to contain a monotonous array of droughttolerant plants, dominated by a few species such as creosote bush, several areas have been found which could be described as sensitive (see figure 3.8-1). The marsh area surrounding Little Lake contains numerous riparian plant species, including desert cordgrass (Spartina gracilis) which has been designated as rare by the California Native Plant Society (CNPS). Other sensitive areas include the small playas north and east of Red Hill cinder cone, which are occasional sources of fresh water, and are important to many annuals. These sensitive areas could be easily degraded by changes in water quantity and quality or excessive disturbance by humans or burros.

\subsubsection{RARE AND LOCALLY ENDEMIC PLANTS}

The GRS site and vicinity contain no plant species, subspecies or varieties noted in the U.S. Department of Interior's Fish and Wildlife Service list of rare, threatened or endangered species. Several species, however, occur on the California Native Plant Society (CNPS) inventory of rare and endangered plants of California (Powell, 1974).

Spartina gracilis (desert or alkali cordgrass) is classified as "very rare, and rare and endangered" (one category). This species is found at Little Lake. Candbya candida, the white canby poppy found near Red Hill on the GRS site is designated as "rare and not endangered." Eschscholzia minutiflora (little gold poppy), Stylocline micropoides (desert nest straw), and Viguiera reticulata (leather leaved viguiera) are designated as "not rare but mostly of limited distribution" and are found on the GRS site or in the immediate vicinity.

The following species, although not listed as rare or locally endemic by the CNPS, are noteworthy because of potential distributional or taxonomic 


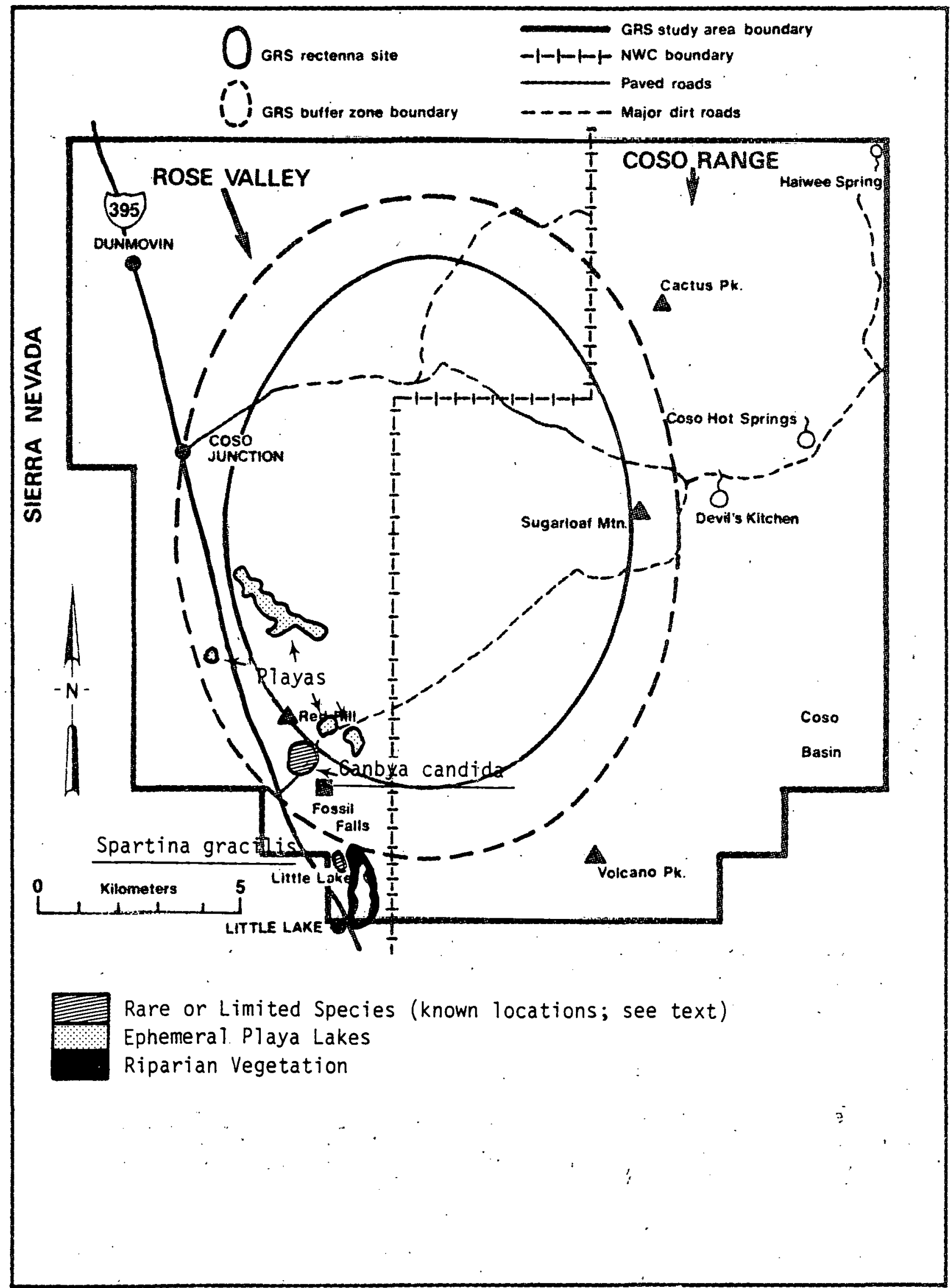

Figure 3.8-1. SENSITIVE VEGETATION AREAS 
significance: Cymopteris ripleyi (Ripley's cymopteris), Euphorbia ocellata (Kerby's spurge), and Lomatium utriculatum (common lomatium).

\subsection{WILDLIFE}

The desert ecosystem of the GRS site, like that of much of the Basin and Range Province, supports a relatively abundant fauna, though there is not a great diversity of species resident. However, because the GRS site occupies part of the broad transition zone between the Mojave and Great Basin desert ecosystems and is adjacent to the Sierra Nevada Mountains, species diversity noted at the Rose Valley site would he expected to be grcater than at sites localed exclusively within either the Mojave or Great Basin desert ecosystems. In llie rulluwling discussion, the wildlife of the GRS site and vicinity are grouped into these major categories: aquatic species, amphibians and reptiles, birds,small mammals and carnivores, and other large mammals. A brief summary description of especially sensitive wildlife habitats and a discussion of rare and protected species encountered also are presented; see Figure 3.9-1 for locations of sensitive habitats.

\subsubsection{AQUATIC WILDLIFE AND HABITATS}

Two aquatic habitat types exist, both outside the GRS site boundaries but in the immediate vicinity, and both are important for at least some of the wildlife species resident within the GRS site: these habitats are Little Lake, and several small streams that flow down the eastern scarp of the Sierras, their waters usually dissipating before entering Rose valley.

Little Lake is a small, shallow body of water approximately 1.5 kilometers in length. The lake is of recent origin; construction of a small earth dam at its southern end allowed a former marsh to flood; maximum depth is only about 1.5 meters. Biologically the lake is very productive, its brown-green color indicating that a dense population of microscopic organisms (plankton) is present. Two species of introduced fish are abundant: the mosquito fish and the Sacramento perch. Other aquatic species include damselflies, mayflies and other insects. The water level is dependent on a constant groundwater source to supply the three springs (along the western shore line) which feed slightly alkaline water into the lake.

Severdl small streams tlow down out of the Sierras and percolate into the gravel alluvium at about 1,200 meters elevation. These streams contain low to moderate mineral content and a good population of aquatic invertebrates (e.g. insects). Water from these streams does not reach the GRS site except during the rare episodes of torrential rains during late summer thunderstorms. 


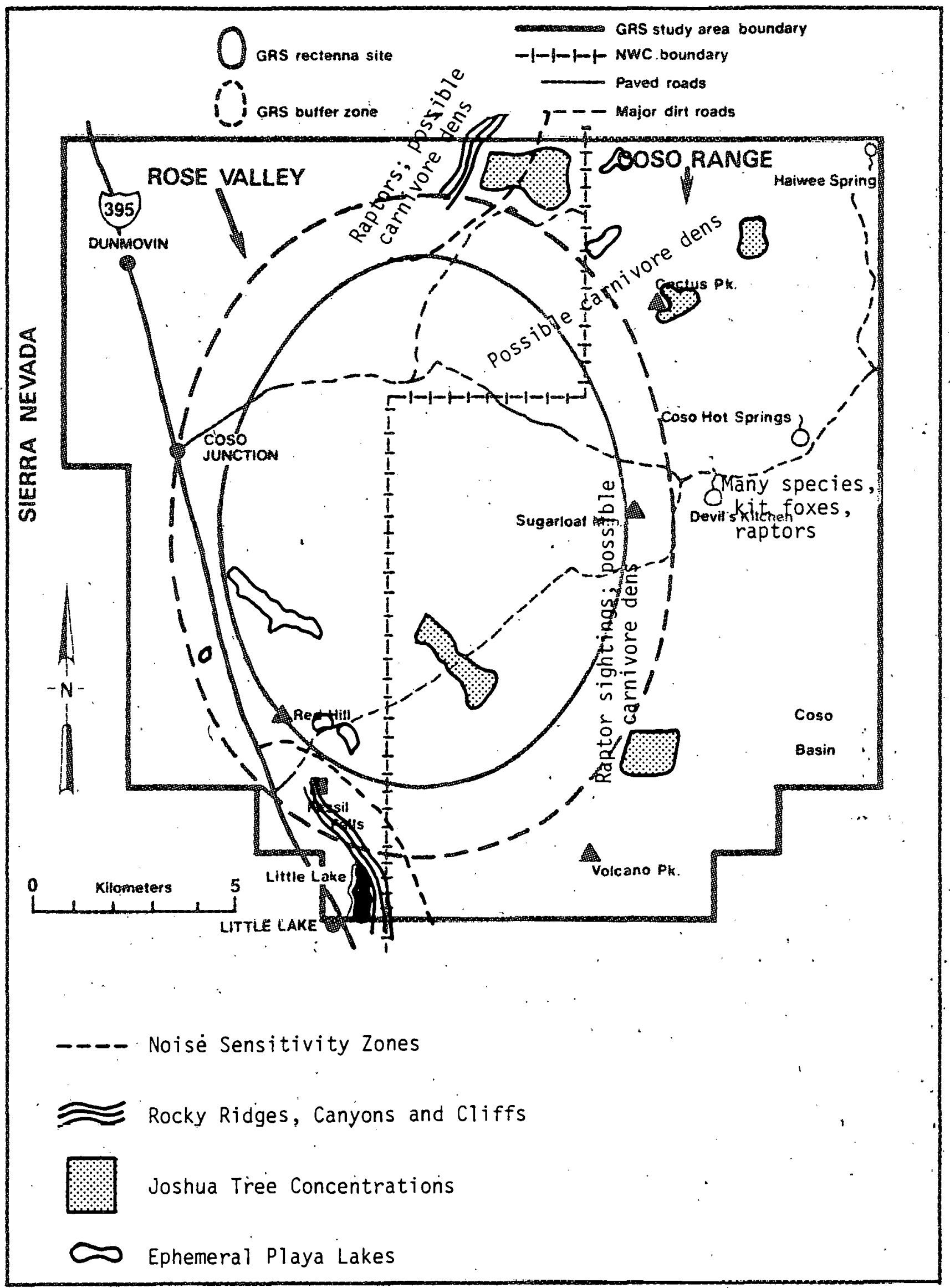

Figure 3.9-1. SENSITIVE WILDLIFE HABITAT AREAS 


\subsubsection{AMPHIBIAN AND REPTILIAN WILOLIFE AND HABITATS}

A total of four species of frogs and toads, 14 species of lizards, 16 species of snakes and one turtle (the desert tortoise) are found in the vicinity of the GRS - site. The majority of species are typical of most of the Mojave Desert to the south and east. A few, such as the western toad, Pacific treefrog, southern alligator lizard, and the northern Pacific rattlesnake, are coastal or Sierran in origin. The bullfrog is native to the eastern states but has been widely introduced in the West and occurs in Little Lake. The remainder of the species are derived from the Great Basin Desert to the north; these include the Great Basin spadefoot toad and striped whipsnake.

\subsubsection{AVIAN WILDLIFE AND HABITATS}

The following discussion is divided into three parts: breeding birds, winter birds, and migratory species. Special attention is paid to raptor (bird of prey) use of the area, and to the possible presence of any endangered, threatened, or rare species.

A breeding bird survey was conducted in eight specially selected areas of the GRS site vicinity during the spring of 1979 (BLM, 1980; see page 34 for full reference). The study plots represent the various habitat types located in the area and are typical of Basin and Range habitats. A total of 33 resident bird species was found in the GRS site and vicinity; 16 were found only at the Little Lake site. An additional 22 migrant species breed in the area but are not year-round residents.

Sixty-eight migrant species were found in the GRS study area during recent field studies. Many of these migrants (23 species) were water birds, which nest in the northern states and Canada and winter at the Salton Sea and along the Gulf of California. As these may settle on any body of water along their migration route, Little Lake and any desert playas that contain water are important habitats for them. Three species of migrant raptors were sighted in the area, along with an additional 42 species of other land hird migrants. Rose Valley is part of a long north-south migration corridor consisting of the Owens, Rose and Indian Wells Valleys. This valley system serves to channel and concentrate migrating birds because of the mountain ranges to the east and west and because of the relative abundance (compared to other desert areas in the vicinity) of surface water.

Wintering avifauna in the GRS study area (as distinct from the migrants stopping on their way south) include water birds, raptors, and other land birds. Water birds congregate at Little Lake, the only suitable habitat for them in the vicinity. Ducks, which are hunted on Little l.ake from mid-0ctober to the end of January, reach peak numbers on the lake just after the close of the hunting season. A total of eight raptor species was observed, most of them in the Rose Valley area. A few other land birds winter in the area; these birds appear to prefer weedy areas around the developed pastures south of Little Lake and at the Rose Valley Ranch.

\subsubsection{MAMMALIAN WILDLIFE AND HABITATS}

Study of the mammalian fauna in the GRS site vicinity was divided into four parts: bats, rodents and lagomorphs (rabbits and hares), carnivores, and other larger animals. 
The permanent bat fauna includes five species, all common and widely distributed throughout the California deserts. Two additional species, both common elsewhere in the West, also were found; they were apparently seasonal transients in the Coso area. No large bat colonies were discovered, however. Bat populations in the GRS vicinity are almost entirely dependent on natural rock crevices for their daytime roosts. Water sources are essential for them and hence should be considered sensitive areas for these mammals.

The rodent and lagomorph (rabbit and hare) fauna includes 16 species. The desert cottontail and black-tailed jackrabbit are commonly observed in all habitat types. Other species found include the California ground squirrel, antel ope ground squirrel, and Botta's pocket gopher. The Mohave ground squirrel, a species officially designated as rare by the California Fish and Game Commission, also was found to be widely distributed throughout virtually all habitats. Ten species of nocturnal rodents were also captured.

Coyotes appear to be the most abundant carnivores in the region. Four other species also were found in a recent field study: the kit fox, which occurs throughout the vicinity; the bobcat, which undoubtedly uses all habitats in the study area; the gray fox, which probably is restricted to the riparian habitat of Haiwee Spring and the rocky canyons nearby; and the ringtail cat (fully protected under California law) which was documentated at two stations in the hills on the east side of Rose Valley and is probably distributed throughout in cliffs and rocky hillsides. In addition, other researchers have reported the presence of the longtailed weasel, badgers (near Coso Hot Springs about six kilometers, east of the GRS study site), and mountain lions (in Joshua Tree Woodland to the north of the GRS site).

The only large mammals in the GRS vicinity other than domestic cattle (and aside from possible mountain lions) are feral burros. Burros are seldom seen in Rose Valley or along the west side of the Coso Range, however, being found mostly near Coso Hot Springs and Haiwee Springs, east and northeast. of the study site. The burro population is presently heavily impacting the area around these water sources; vegetation is severely trampled and overbrowsed.

\subsubsection{SENSITIVE WILDLIFE AREAS AND HABITAT TYPES}

Sensitive habitats within the study area are typical of sensitive habitat types found throughout the Basin and Range Province. Little Lake and Haiwee Spring are extremely important habitats for many species of birds, amphibians and mammals. In addition both are sensitive areas: Little Lake, as the only sizable body of surface water near the site, could be greatly affected by excessive drawdown of groundwater, causing it to revert largely to marshland. Little Lake is especially significant for migrating and wintering birds, as well as many resident bird species. (Haiwee Spring is beyond the zone of GRS impacts and hence is not discussed.) Desert washes and ephemeral-playa lakes are also sensitive habitats. Desert washes are important habitats for many reptiles; several playas east and north of fied Hill and north of Cactus Peak provide important occasional water sources in this arid region for birds when they contain water. Joshua Tree Woodland provides good habitat for many breeding birds as well as other forms of wildlife. This habitat is found as well as in the slopes of the southeastern part of Rose Valley, in the mountains between Volcano Peak and Sugarloaf Mountain, around and north 
of Cactus Peak, and at various scattered locations. In these same areas, and other higher, rocky hillsides and cliffs, carnivore dens and raptor meeting sites may be expected.

\section{3:9.6 ENDANGERED, THREATENED 'AND RARE SPECIES}

None of the species encountered, known or expected within the GRS site vicinity is on federal or state listings of threatened or endangered species. Only one species (the Mohave ground squirrel) is listed as rare by the California Fish and Game Commission; recent studies have shown this species to be relatively abundant in virtually all habitat types in the Rose Valley area. The ringtail cat, a carnivore, and the desert tortoise (the California State reptile), are fully protected under California law, though not included in state or federal listings of rare, threatened or endangered species. The ringtail probably utilizes all habitats within the Rose Valley/Coso area. The one desert tortoise encountered may have been a vagrant or a released pet; the study area is thought to be near the northern end of its rangc. No other rare or protected wildlife species are known within the study arca, though several relatively uncommonly sighted raptors were observed.

\subsection{LAND USE}

Land uses and land use trends within the GRS study area and its immediate vicinity are discussed in the following section. In general, land use within the region, like that throughout rural portions of the Basin and Range Province, is not notably intensive (less than 30 percent on average), nor is it particularly extensive (approximately 15 percent of the land has no designated use; except for seasonal cattle grazing and occasional recreational activity, at least half of the region would otherwise be classified as Open Space/No Designated Use). In accordance with current land use policy of most agencies of the federal government (which control nearly 92 percent of the land in the region), multiple uses of land exist over approximately 35 percent of the area. The most common examples of coexisting land uses are recreation, natural resource management, grazing, and mining activities. Urbanized land uses within the region account for less than 0.4 percent of the total land area. Table 3.10-1 provides a summary of present regional urbanized land uses for comparative and reference purposes; Section 3.11 discusses urban uses in more detail.

\subsubsection{HISTORICAL LAND USE TRENDS}

The most important historic land uses in the region have been mining, ranching, and limited farming, beginning in the 1860 s with the establishment of the first permanent non-Indian settlement.s in Rose and Owens Valleys. Gold and silver discoveries provided the major impetus to economic growth and the establishment of a land use pattern dorninated by mining and mineral processing activities, followed by isolated ranching and agricultural uses as public lands were homesteaded." (See Section 3.12 for a discussion of prehistoric occupancy of the area and probable prehistoric land uses.)

\subsection{0 .2 SUMMARY OF PRESENT LAND USES AND LAND USE TRENDS}

Undisturbed natural areas within the region exist in three categories, (see Figure 3.10-1). The first category, Congressionally-designated Wilderness 
Table 3.10-1. SUMMARY OF PRESENT REGIONAL "URBANIZED AREA" LAND USES

(all figures in square kilometers)

\begin{tabular}{lll}
\hline & $\begin{array}{l}\text { Estimated } \\
\text { Population "Urbanized" } \\
\text { "Greater" Urbanized Area }\end{array}$ & $\begin{array}{l}\text { Per Capita } \\
\text { Urbanized } \\
\text { (1980) }\end{array}$
\end{tabular}

Ridgecrest/China Lake

(excluding NWC

operations)

21,900

21

0.00098

12.4

5.4

1.6

1.3

Trona/Searles Valley

4,460

4.1

0.00093

1.6

0.4

1.8

0.4

Inyokern/Brown-Road

(includes Inyokern

Airport)

3,200

3.4

0.00106

0.5

1.8

0.08

2.6

or Lone Pine (includes

Indian Reservation and

Airport)

1,750

3.1

0.00176

1.0

0.5

0.01

1.6

01 ancha/Cartago/Grant

550

0.39

0.00075

0.3

0.01

0.01

0.13

TOTALS for Urbanized Areas within Study Region

31,860

31.7

0.00109

15.8

6.6

3.4

5.9

Non-Urban Area TOTALS

2,100

-- $\quad$--

2.3

1.2

6.2

45.8

Regional TOTALS

(Urban and Non-Urban Areas)

33,960

-- $\quad$--

18.1

7.8

10.4

51.8 


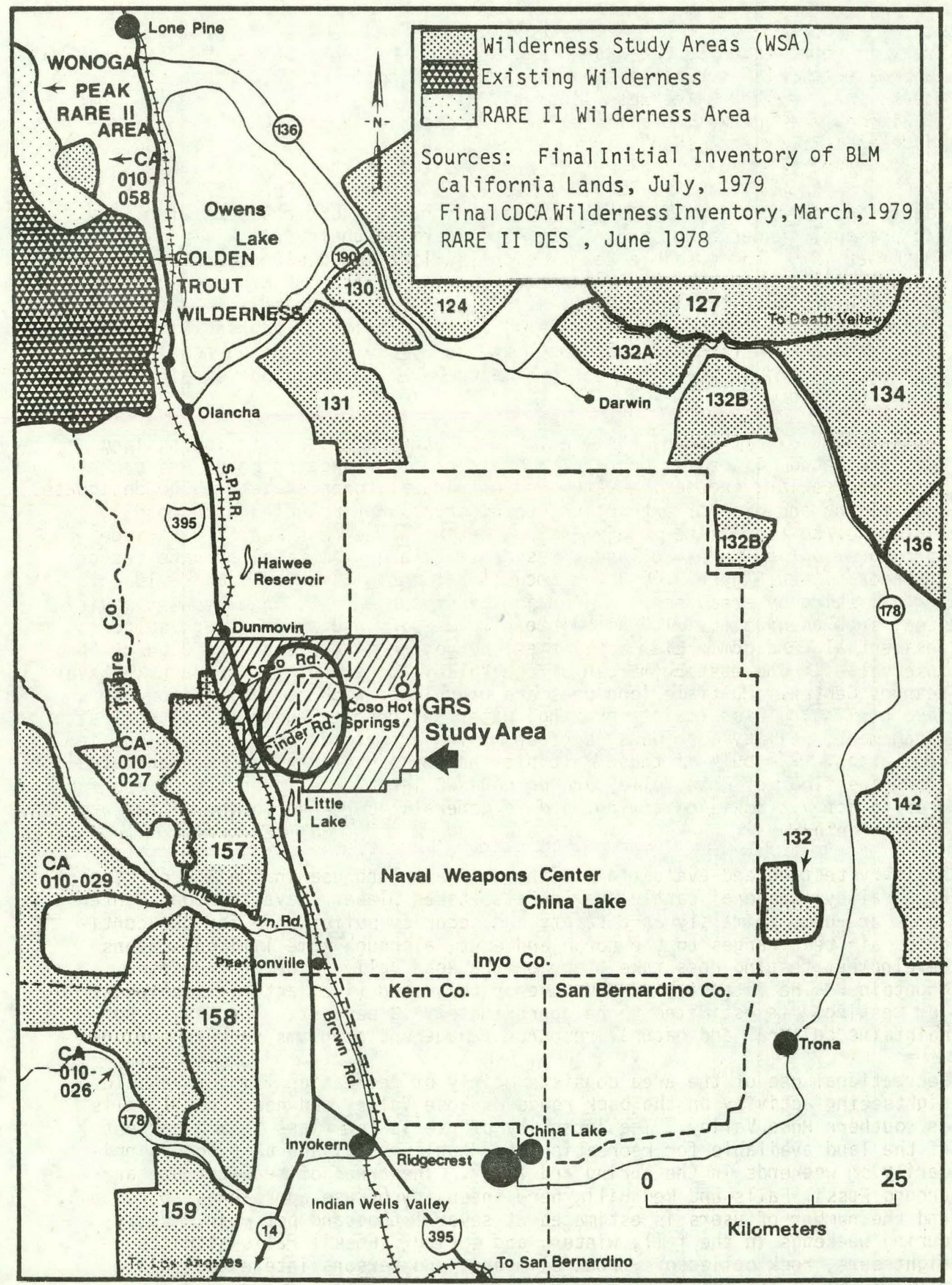

Figure 3.10-1. WILDERNESS AND WILDERNESS STUDY AREAS 
Area, is represented by the eastern edge of the Golden Trout Wilderness (approximately 180 square kilometers) running from 01 ancha Creek to Cottonwood Creek; the Domeland Wilderness lies well outside the regional boundary, some 32 kilometers southwest of Little Lake. Another category, BLM-designated Wilderness Study Area (WSA), is located throughout the region. WSAs occupy approximately 790 square kilometers (roughly $10 \%$ of the region). These areas (WSA 124, 130, 131, 132, 132A, 132B, 157, 158, 159, and 157) were identified during intensive inventories for the Cal ifornia Desert $\mathrm{Pl}$ an, and are presently undergoing study by BLM to determine their suitability, by September 1980, for possible Congressional wilderness designation. Recommendations will be made in the California Desert Plan as to their suitability or non-suitability for inclusion in the National Wilderness Preservation System. A small (38 square kilometers) Administratively Endorsed Wilderness Area, Wonoga Peak (located just north of the Golden Trout Wilderness), has been recommended by the U.S. Forest Service as wilderness under their RARE II review program.

Within the vicinity of the Rose Valley/Coso study area, the following land uses are found, listed in decreasing order of importance: grazing and rangeland; recreation; protective watershed withdrawal; open space with no designated use; mining and mineral extraction; transportation (including dirt roads); historical/cultural site management; potential wilderness; utility service corridors; agriculture/croplands; residential; and commercial/private sector services. (See Figure 3.10-2 for location of these uses and Table 3.10-2 for a listing by area used.) The majority of the area is under low intensity uses, such as grazing, with high intensity uses (e.g. irrigated agriculture, residential, and commercial activities) occupying only a small portion of the Rose valley, The eastern margin of the Valley is part of the China Lake Naval Weapons Center. Multiple land uses are prevalent, with as many as four or five coexisting uses (mainly grazing, water resource management, cultural site management, utility corridors, surface mining activities, and recreation) in some areas. The bulk of these multiple-incidence use areas are concentrated along the floor of Rose Valley and on non-NWC land. The intensity of use for grazing activities is quite low, and is generally confined to the winter and spring months.

Military testing and evaluation is the dominant land use in the NWC portion of Rose Valley; seasonal cattle grazing also takes place. Naval Weapons Center ldnds are used primarily as a safety and security buffer zone for the contiguous air test ranges to the north and east, although some 1 imited weapons development testing does take place on the Rose Valley side of the Coso Mountains. The intensity of Navy use of this land (i.e. actual time in use for testing), is estimated to be approximately 10 percent. The Navy also maintains cultural and natural resource management programs in this area.

Recreational use of the area consists mainly of recreational motor vehicle sightseeing activity on the back roads of Rose Valley and near Fossil Falls in southern Rose Valley. The intensity of use is low (less than $b$ percent of the land available for recreation is actually used, and this occurs primarily on weekends in the spring and fall). The areas of heaviest use are around Fossil Falls and Red Hill; here intensity of use approaches 25 percent, and the number of users is estimated at several thousand per year, mostly during weekends in the fall, winter, and spring. Fossil Falls attracts sightseers, rock collectors, rock climbers, and persons interested in lhe archaeology of the area. 
Table 3.10-2. SUMMARY OF PRESENT GRS SITE LAND USES

\begin{tabular}{|c|c|c|c|}
\hline Type of Use & $\begin{array}{l}\text { Approximate } \\
\text { Number of } \\
\text { Hectares* }\end{array}$ & $\begin{array}{l}\text { Approximate \% } \\
\text { of GRS Site* } \\
\text { (including } \\
\text { buffer zone) }\end{array}$ & $\begin{array}{l}\text { Estimated } \\
\text { Intensity } \\
\text { of Use }(\%)\end{array}$ \\
\hline $\begin{array}{l}\text { Grazing/Rangeland } \\
\text { Military Testing and }\end{array}$ & 15,000 & 96 & 25 \\
\hline Evaluation & 6,000 & 38 & 10 \\
\hline Recreation (including MV use) & 9,000 & 58 & 5 \\
\hline Water Resource Management & 9,000 & 60 & 1 \\
\hline & 100 & 1 & 35 \\
\hline $\begin{array}{l}\text { only) } \\
\text { Hictorical }\end{array}$ & 5 & 1 & 50 \\
\hline Management & 400 & 3 & 100 \\
\hline Utility Service Corridor & 80 & 1 & 25 \\
\hline TOTAL GRS SITE & 15,500 & -- & -- \\
\hline
\end{tabular}

*Totals more than $100 \%$ because of multiple uses, each of which is listed separately. 


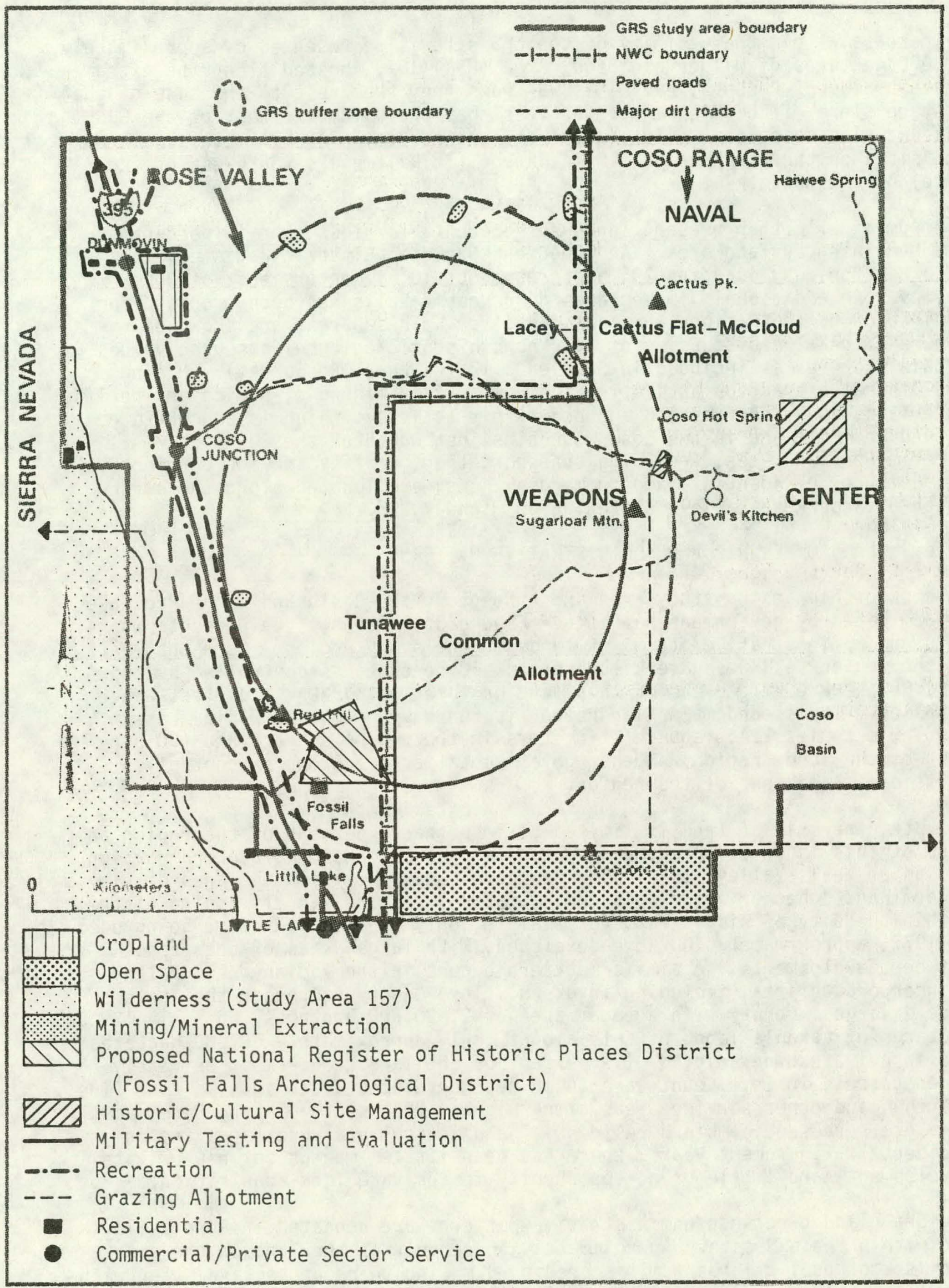

Figure 3.10-2. PRESENT LAND USES WITHIN THE STUDY AREA 
Wilderness within the vicinity of the GRS site is represented by approximately 10,000 hectares of Wilderness Study Area (WSA) 157, located along the extreme western side of Rose Valley. This WSA runs from the crest to the base of the eastern slope of the Sierra Nevada (less than one kilometer west of the GRS site at closest contact point) and from Tunawee Canyon ( 5 kilometers west of the site) on the north to Nine Mile Canyon ( 15 kilometers southwest of the site) on the south.

The sum of all other present land uses accounts for less than 10 percent of the remaining surface area. An important National Historic Register Site, Coso Hot Springs, occupies 295 hectares about 10 kilometers east of Rose Valley. An additional 310 hectares near Fossil Falls has been proposed for nomination to the National Historic Register. These areas are shown on Figure 3.10-2. A discussion of all known historic/cultural resource values within the area is included in Section 3.12 (Cultural Resources). Mining and mineral extraction activities include surface mining of pumice and perlite materials, and cinder mining and borrow pit activity, which is concentrated around Red Hill and in the Coso Mountains just north of the GRS site. All other minor land uses, including transportation, utility service corridors, agriculture, residential, and commercial uses, are located along the northsouth axis of Rose Valley, centering on Highway 395.

\subsubsection{LAND OWNERSHIP AND ADMINISTRATIVE PATTERNS}

Land ownership in the study area and throughout the Basin and Range Province is dominated by government holdings. Figure $3 \cdot 10-3$ shows the present ownership and administrative status of lands in the study region. More than half of the region $(4,870$ square kilometers or 58 percent) is controlled by the BLM; 855 square kilometers of this 1 and has been withdrawn to protect water supplies. The second major landholder is the Navy, whose NWC China Lake Complex occupies 2,460 square kilometers in the region's heartland ( 30 percent of the study region). Other governmental agencies own or control an additional 8 percent of the region.

Private ownership of 1 and is limited to less than 4 percent of the region and most of this land is concentrated around Ridgecrest and the Inyokern portion of Indian Wells Valley (IWV). The few developed parcels in the area display a predominant "checker board" pattern. Of 2,847 hectares in all zoning districts within the City of Ridgecrest, for example, only 599 hectares were being used in 1977; approximately 400 were developed, with large areas of open space between developments. A similar pattern occurs in the Indian Wells Valley unincorporated area, including Inyokern. Inyo County, although the state's second largest county with a total area of 2,620,600 hectares, has only 129,500 hectares of taxable land; of this amount, only approximately 50,000 hectares are in private ownership, or 1.9 percent of the land area. Most privately owned parcels in Inyo County are in or near developed areas such as Lone Pine, 0lancha, and other service areas along Highway 395; south of Long Pine, most of these represent combined residential and agricultural uses; grazing is incidental. In recent years, there has been little impetus for new private development, and little or no opportunity for private land acquisition.

Regional land ownership/administrative patterns are repeated in Rose Valley. and within the GRS site. Approximately 60 percent of the land in the site consists of public lands administered by BLM (including protective water withdrawal); the Naval Weapon Center administers another 35 percent of the site, 


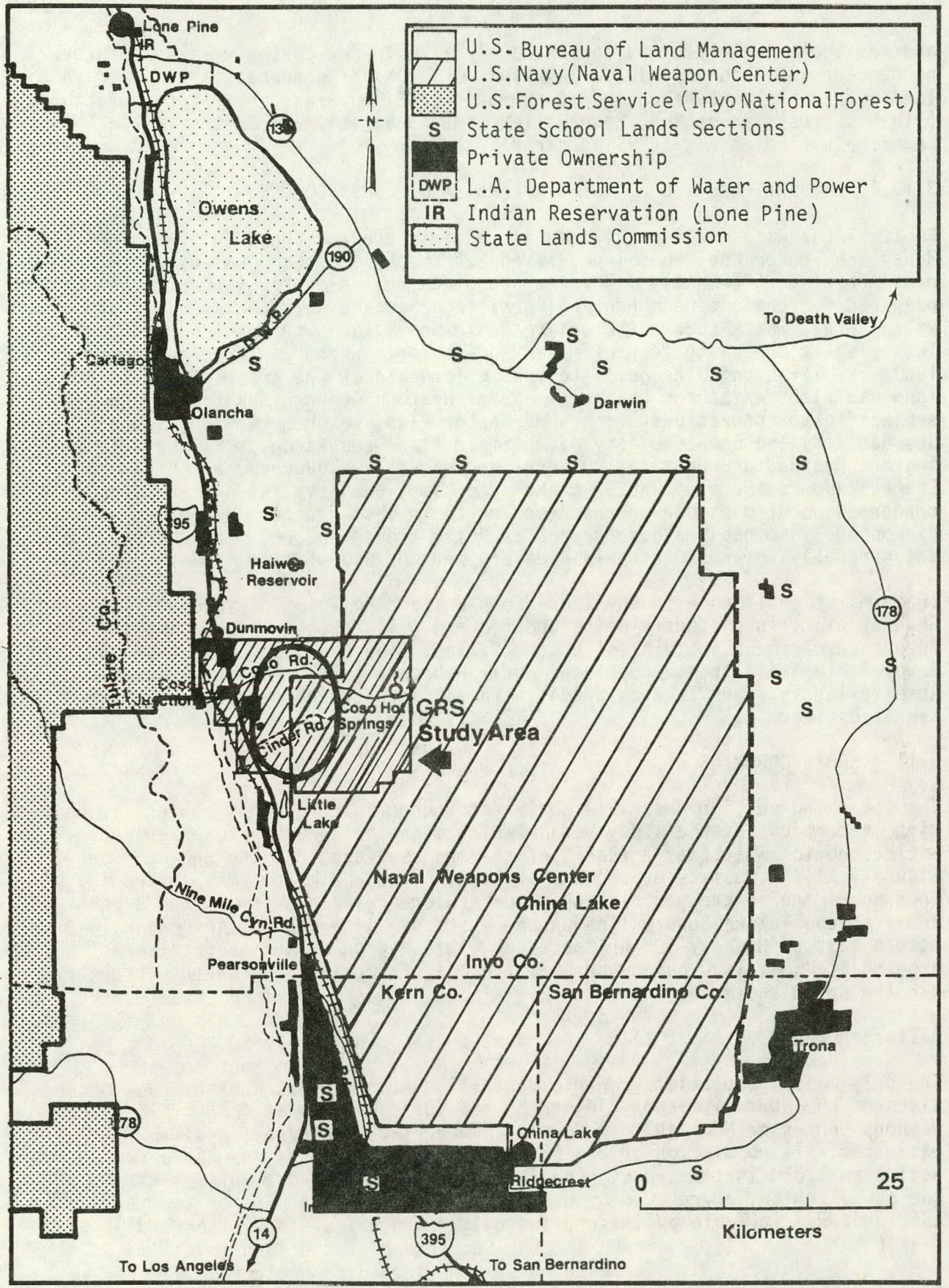

Figure 3.10-3. REGIONAL LAND OWNERSHIP AND ADMINISTRATIVE STATUS 
and the State of California approximately 2 percent, leaving less than three percent of the land in private ownership. The major concentrations of private land within the study area are at Dunmovin (345 hectares), near Coso Junction ( 110 hectares), in central Rose Valley ( 390 hectares), and in the Little Lake/ Fossil Falls area (295 hectares).

\section{10.4 PRESENT LAND USE POLICIES, PLANS, AND PERMITTED USES}

Public lands within the study area are administered by the U.S. Bureau of Land Management under the general provisions of the Federal Land Policy and Management Act of 1976 (FLPMA). This Act required that a master land use plan be prepared for the entire roughly five million hectare California Desert Conservation Area, which covers the entire Basin and Range section of California. This plan is presently in preliminary draft form; when completed in September 1980, it will become the guide to public land use in the area. No other BLM land use plans exist for the area. Naval Weapons Center (NWC) lands are subject to the provisions of the NWC Master PIan, which acknowledges the desirability and compatibility of multiple land uses, such as Military Testing and Evaluation, Grazing, Cultural and Natural Resource Management, and Energy Resource Development. At the same time, the Navy is continually concerned about possible encroachment on their test ranges; NWC policy is to discourage incompatible development activity around the perimeter of the NWC and generally to prohibit non-NWC development or use of base lands.

In terms of applicable county land use plans and policies, Inyo County's 1990 General plan, is presently being updated and will reflect the possibility of future development activities in Rose Valley. The Land Use Element of the new General Plan will not be completed until February 1980. Presently land in Rose Valley is zoned as Open Space, with all development requiring a Conditional Use Permit.

\subsection{SOCIOECONOMICS}

The following section describes social and economic conditions currently occurring in portions of the study region which might be expected to experience socioeconomic impacts as a result of the proposed action. The region (see Figure $3.11-1$ ) consists of approximately 2,250 square kilometers, extending from Lone Pine in the north to China Lake/Ridgecrest/Inyokern in the south and from the Tulare County line on the west to a line running several kilometers east of Highway 395 on the east. This region of sparse settlement and isolated, small urban centers is typical of settlement patcerns throughout the Basin and Range Province.

\subsection{1 .1 POPULATION}

The only major population/economic center located within the study region consists of the communities of Ridgecrest and China Lake (part of the U.S. Naval Weapons Center or NWC) in Kern County. These two communities had a total estimated 1977 population of 21,402; rural Indian Wells Valley (IWV) had an estimated 3,350 in that year. Population data for the Kern County portion of the study region, aggregated by U.S. Census Tracts, is shown for the years 1960 and 1977 in Table 3.11-1. Between 1970 and 1977, China Lake population 


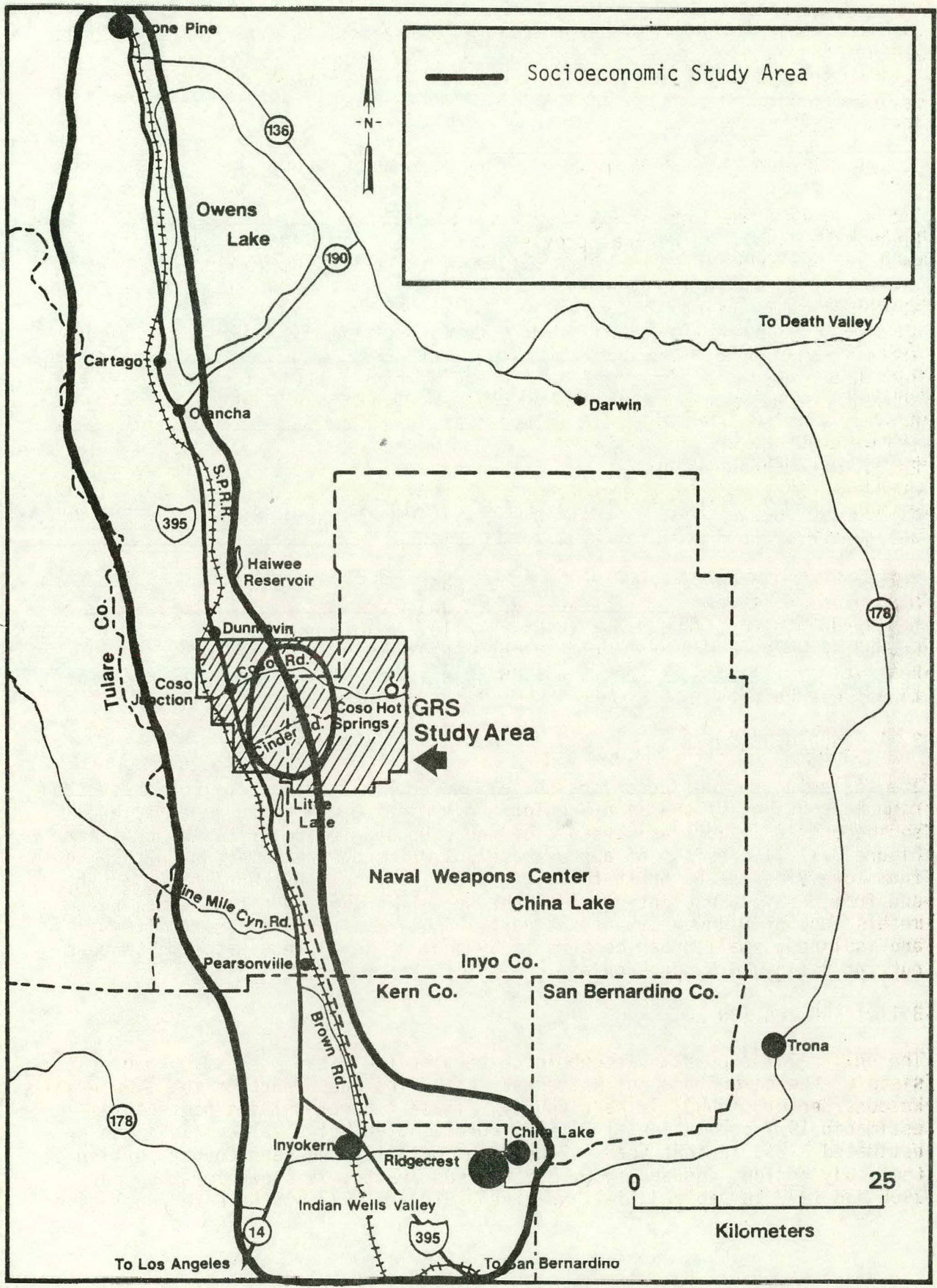

Figure 3.11-1. SOCIOECONOMIC STUDY REGION AND GEOGRAPHIC REFERENCES 
Table 3.11-1 STUDY REGION POPULATION DATA: 1960, 1970, AND 1977

\begin{tabular}{|c|c|c|c|c|c|}
\hline 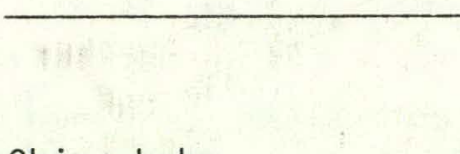 & 1960 & 1970 & $\begin{array}{l}\text { Rate of } \\
\text { Change } \\
1960-70 \\
\end{array}$ & 1977 & $\begin{array}{l}\text { Rate of } \\
\text { Change } \\
1970-77\end{array}$ \\
\hline $\begin{array}{l}\text { China Lake } \\
\text { (Census Tract 53) }\end{array}$ & 11,748 & 11,105 & $-5.5 \%$ & 6,135 & $-44.8 \%$ \\
\hline $\begin{array}{l}\text { Ridgecrest } \\
\text { (Census Tract } 54 \text { ) }\end{array}$ & 5,506 & 8,499 & $+54.4 \%$ & 15,267 & $+79.6 \%$ \\
\hline Subtotal: & 17,254 & 19,604 & $+13.6 \%$ & 21,402 & $+9.2 \%$ \\
\hline $\begin{array}{l}\text { Rural Indian Wells } \\
\text { Valley (including } \\
\text { Inyokern) } \\
\text { (Census Tract } 55.01 \text { ) }\end{array}$ & 716 & 1,738 & $+142.7 \%$ & 3,349 & $+92.7 \%$ \\
\hline $\begin{array}{l}\text { Subtotal: } \\
\text { Kern County Tracts }\end{array}$ & 17,970 & 21,342 & $+18.8 \%$ & 24,751 & $+16.0 \%$ \\
\hline Southwest Inyo County & 2,467 & 2,672 & $+8.3 \%$ & 2,508 & $-6.1 \%$ \\
\hline Total Study Area & 20,437 & 24,014 & $+17.5 \%$ & 27,259 & $+13.5 \%$ \\
\hline Inyo County & 11,684 & 15,571 & $+33.3 \%$ & 17,967 & $+15.4 \%$ \\
\hline
\end{tabular}


decreased by approximately 5,000 due to implementation of a Navy policy to encourage personnel to live off base; a roughly corresponding increase in the population of Ridgecrest and rural IWV resulted. Ridgecrest and Inyokern are also presently experiencing in-migration. Inyo County, which contains the balance of the study region, is thinly populated, with 23 percent of the total 1970 county population of 15,571 living 135 kilometers north of the GRS site in the one incorporated city -- Bishop. The southwestern portion of the county, which includes Rose Valley, had a total population of 2,672 in 1970; most of this population is located in the communities of Lone Pine and 01 ancha (1,800 and 260, respectively, populations in 1970). The remainder, approximately 600 persons, live in small settlements; a small number -- an estimated 30 in 1979 -inhabit Rose Valley area, including the settlements of Haiwee, Grant, Dunmovin, and Little Lake. Population data for Inyo County and for the southwestern portion of the county for 1960-1977 are shown in Table 3.11-1.

Population characteristics for Ridgecrest, China Lake, Inyo County, and California in 1970 are shown in Table 3.11-2. Such characteristics are typical of populations throughout the Basin and Range Province, with the exception of the high educational achievement levels in the Ridgecrest-China Lake area associated with employment at the Naval Weapons Center.

\subsection{1 .2 HOUSING}

The total number of housing units in China Lake and the City of Ridgecrest in 1975 was 2,835 and 4,640 respectively; the total number of housing units in the Inyo County portion of the study area in 1977 was 1,337. While little housing is available in the Inyo County area, the transfer of several thousand people from the NWC has generated considerable pressure for new housing in the City of Ridgecrest and in Inyokern and has stimulated private development. Between 1970 and 1975, total housing units in Ridgecrest increased 52 percent; since that time, construction has continued at the rate of several hundred new homes per year. However, three major builders recently closed activities in Ridgecrest, leaving future housing to be supplied by a number of small local builders.

By late 1979, 600 units of excess Navy housing (known as the Wherry Tract) will become available to Ridgecrest residents, bringing total available housing stock in the City to 6,228 units, with a vacancy rate of 14 percent (872 units). An additional 1,100 units (approximately) of excess Navy housing (and 220 hectares of NWC land) could be made available to the City of Ridgecrest.

The total number of dwelling units in rural Indian Wells Valley (including Inyokern) has approximately doubled since 1970, when there were 623 units and a vacancy factor of 11 percent. By 1979, activity was concentrated in the Brown Road area (to the north of Inyokern) and extending north toward the Inyo County 1 ine.

Of the 1,337 units in the Inyo County portion of the study region in 1977 , at least 121 ( 9.1 percent) were vacant, and probably many of these are unsuitable for occupancy; perhaps one-third of the dwellings in Inyo County are over 40 years old, and, in $1960,41.8$ percent were substandard (i.e., dilapidated, deteriorating and/or lacking in some or all plumbing facilities). The few housing units in Rose Valley are generally quite old, and probably most lack modern conveniences and facilities. Single family homes are placed 
Table 3.11-2. POPULATION CHARACTERISTICS OF RIDGECREST, CHINA LAKE, INYO IOUNTY AND CALIFORNIA, 1970

\begin{tabular}{|c|c|c|c|c|}
\hline 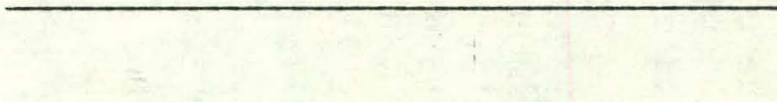 & $\begin{array}{c}\text { China Lake } \\
\text { (Unincorporated) }\end{array}$ & Ridgecrest & Inyo County & $\begin{array}{l}\text { State of } \\
\text { California }\end{array}$ \\
\hline Total Population & 11,114 & 7,629 & 15,571 & $19,953,134$ \\
\hline Total Native Population* & 10,808 & $7,50<$ & 15,161 & $18,199,313$ \\
\hline $\begin{array}{l}\text { Percent of Native Population } \\
\text { Born in Different States }\end{array}$ & 57.9 & $5 \bar{i} \cdot 0$ & 42.7 & 47.4 \\
\hline Total Population 5 Years or 01 der & 10,077 & 6,924 & 14,462 & $18,317,974$ \\
\hline $\begin{array}{l}\text { Percent of Populatior } 5 \text { Years } 01 \mathrm{~d} \text { or } \\
\text { Over Living in Same touse ir } 1965\end{array}$ & 27.6 & 38.3 & 42.1 & 43.5 \\
\hline $\begin{array}{l}\text { Median School Years Completed, } \\
\text { Males, } 25 \text { Years 01d or Over }\end{array}$ & $\begin{array}{l}13.8 \\
12.6\end{array}$ & 12.4 & $\begin{array}{l}12.3 \\
12.3\end{array}$ & 12.4 \\
\hline $\begin{array}{l}\text { Percent High School Graduates, } \\
\text { Males, } 25 \text { Years 01d or Over } \\
\text { Percent High School Graduates, } \\
\text { Females, } 25 \text { Years 01d or Over }\end{array}$ & 76.9 & $\begin{array}{l}\text { (no data } \\
\text { available) } \\
\text { (no data } \\
\text { available) }\end{array}$ & 58.4 & 62.7 \\
\hline Percent Non-Caucasian & 5.5 & 3.0 & 8.3 & 10.6 \\
\hline Percent Under 18 Years & 40.1 & 36.3 & 32.5 & 33.3 \\
\hline Percent 18 to 64 Years & 59.0 & 57.5 & 56.0 & 57.7 \\
\hline Percent 65 Years and 0ver & 0.9 & 6.1 & 11.6 & 9.0 \\
\hline
\end{tabular}

Source: U.S. Census of Population, 1970.

*Persons born in U.S., Puerto Rico, or a possession of the U.S.; or if born outside these areas, having one parent who was a U.S. citizen. 
on the market only infrequently in the Inyo portion of the study region, and rentals are even more scarce. A few motels and mobile home parks in the area have occasional vacancies. The Little Lake Hotel makes rooms available on a monthly basis, and additional mobile homes or single-family units could be sited in such locations as 01 ancha/Cartago and Pearsonville.

\subsection{1 .3 INFRASTRUCTURE}

\subsubsection{Police Protection}

Police services are provided on all state and U.S. highways throughout the study region by the California Highway Patrol (CHP) in cooperation with Inyo and Kern County Sheriff's Departments. The Inyo County Sheriff's Department maintains substations in Lone Pine and 0lancha; the 0lancha substation serves the Rose Valley area. The Kern County Sheriff's Department has an office in Ridgecrest. Both China Lake and the City of Ridgecrest have police departments, and the NWC maintains a range security patrol within its boundaries. In addition, BLM rangers cooperate with 1 ocal and state agencies.

\subsubsection{Fire Protection}

Public lands in the socioeconomic study region are protected through cooperation between the Navy (on NWC lands), BLM, U.S. Forest Service, and the California Division of Forestry. Lone Pine and other small Inyo County communities, including 01 ancha, have fire protection districts operated by volunteers. Fire protection services in the Kern County portion of Indian Wells Valley are provided by the Kern County Fire Department, with stations in Ridgecrest and Inyokern; the Ridgecrest station has a mutual aid agreement with the NWC Fire Department.

\subsubsection{Electrical Utility}

Both Southern California Edison (SCE) and the Los Angeles Department of Water and Power (LADWP) maintain power lines which run approximately parallel to Highway 395. SCE provides residential electrical service to the portion of the study region south of 01 ancha (including Rose Valley), while Lone Pine and the Owens Valley are served by LADWP.

\subsubsection{Fresh Water Supply}

Rose Valley and 01 ancha residents supply their own fresh water through wells or springs. Ninety-five percent of the residents in the Lone Pine area are supplied water by LADWP and the North Lone Pine Water District. The community of Cartago has its own water system. The Indian Wells Valley County Water District (IWVCWD) serves a 85-square kilometer area of Kern and San Bernardino Counties, including most of the City of Ridgecrest. Two small water companies serve portions of Inynkern, but most residents obtain water from individual wells.

\subsubsection{Gas Utility}

Natural gas is supplied to about half the population of Ridgecrest by the Pacific Gas and Electric Company. The remainder of the population in the study area relies on propane, which is distributed by various suppliers. 


\subsubsection{Sewage/Wastewater Treatment}

Most small communities and all of the rural areas of Inyo County (including Rose Valley) use septic tanks. Both Lone Pine and Cartago have sewers, but the systems are inadequate. Sanitary sewer services are provided to the residents of Ridgecrest and China Lake through a combined system; the treatment plant has a rated capacity of 3.1 million liters per day with current usage well below capacity. Inyokern County Sanitation District serves approximately 300 persons with a treatment system designed to handle a maximum of 225,000 litres per day, current flow is approximately 115,000 liters per day. The remainder of the population of rural Indian Wells Valley relies on septic tanks.

\subsubsection{Solid Waste Disposal}

The closest disposal site capable of accepting Class I (i.e. hazardous wastes, exclusive of radioactive, explosive, and other excluded materials) wastes is located in West Covina, in Ins Angeles County. Househuld wastes can be taken to Cilass II and II-2 sites; there arc several CldSS II-2 sites located in or near the study region, including an extensive private facility east of Lone Pine, which is capable of accepting large quantities of ordinary municipal rubbish for an additional 28 years, and the Kern County-operated Ridgecrest Sanitary Landfill, located on lands managed by BLM south of Ridgecrest city limits. The Ridgecrest facility has an expected completion date of approximately 1982; however, approval is being sought from BLM for expansion to adjacent 1 ands, which would provide an additional 15-20 years' capacity. Collection in both Inyo County and Kern County portions of the socioeconomic study region is by 1 icensed, private contractors.

\subsubsection{Health and Mental Health Systems}

Inyo County maintains a public medical clinic in Lone Pine. Lone Pine's Southern Inyo Hospital serves the southern portion of the county. The Kern County Health Department (Nursing Division) maintains an office in the City of Ridgecrest. Ridgecrest Community Hospital and Drummond Outpatient $\mathrm{Clinic}$ serve the Ridgecrest/ Inyokern area.

\subsubsection{Education Systems}

The Lone Pine Unified School District serves the southwestern portion of Inyo County. The district has two elementary schools, one in 0lancha and one in Lone Pine, and a high school and a continuation high school, both in Lone Pine. Olancha Elementary School, with an enrollment of 50 and a capacity of 100 students, serves Rose Valley and other rural areas; Lone Pine Elementary School has an enrollment of 280 and a capacity of approximately 310 ; and Lone Pine High School has an enrollment of approximately $13 \mathrm{~b}$ and a capacity of 200 students. Enrollment in the district has been declining.

The Sierra Sands Unified School District serves the Indian Wells Valley portion of the socioeconomic study region. Total enrollment for the eight el ementary schools, two junior high schools, high school, continuation high school, and adult education program was approximately 5,200 in autumn of 1979; this was about 1,460 bel ow capacity. Limited higher education is available at Cerro Coso Community College in Ridgecrest and through extension courses taught at the Naval Weapons Center Training Center. 


\subsubsection{Social Service Systems}

Inyo and Kern Counties provide limited welfare and other social services in the study area. The Inyo County Welfare.Department is located in Independence; additional services are provided to Native Americans in the Owens Valley. The Kern County Public Welfare Department has a district office in Ridgecrest.

\subsubsection{Recreation}

Many opportunities for dispersed recreational activities are provided by the region's National Parks, Forests, and Monuments. BLM-administered lands are generally open to the public for recreational use; and some LADWP 1 ands in Inyo County are also available. Inyo National Forest and BLM campgrounds are accessible from Highway 395; several campgrounds are located in the areas south and north of Rose Valley in the Sierras. Opportunities for recreation al so exist at Diaz Lake, two miles south of Lone Pine. Parks in the Ridgecrest/ China Lake area include: the county-operated 40-hectare Kern Desert Regional Park; Helmer's Park (2.5 hectares); the Sgt. John Penney Pool; several undeveloped single-lot parks in Ridgecrest; and Navy parks and recreational facilities which are available for use by the population of Ridgecrest.

\subsubsection{TRAFFIC AND TRANSPORTATION SYSTEMS}

The highway system in the study area, and annual average daily traffic in 1978, are indicated in Figure 3.11-2. The most important access highway serving the area is U.S. Route 395, the only north-south artery through the region, and a designated scenic highway between the Lone Pine area and the Inyo/Kern County line. Highway 395 carried a daily traffic volume of approximately 4,400 vehicles near the study area in 1978, and a peak load of 7,000 vehicles per day or more during August. The Rose Valley portion of the highway is a divided four-lane facility with at-grade intersections; south of the Inyo/Kern County line and north of Dunmovin it is a two-lane undivided roadway.

\subsubsection{Recreational Traffic}

The regional highways of this area experience high proportions of recreational traffic. In general, during the months of May through October, traffic volumes on Highway 395 and other major roads are considerably higher than during the rest of the year. Weekend recreational traffic (particularly holiday weekends) during the winter is also very heavy.

\subsubsection{Truck Traffic}

Truck traffic represents a high proportion of traffic on vicinity highways, particularly U.S. Route 395 and Route 178. The trucking industry plays an important role in the movement of goods and farm produce in this region, where roads provide access to remote locations unreachable by rail. Most lruck traffic is interregional.

\subsubsection{Rail Transportation}

The Southern Pacific Railroad serves the study area with a line from the Southern California area northward to Lone Pine. This runs roughly parallel to Highway 395 and provides transportation for lumber and mineral ores to the south. A siding is located at Coso Junction. The Southern Pacific Railroad, 


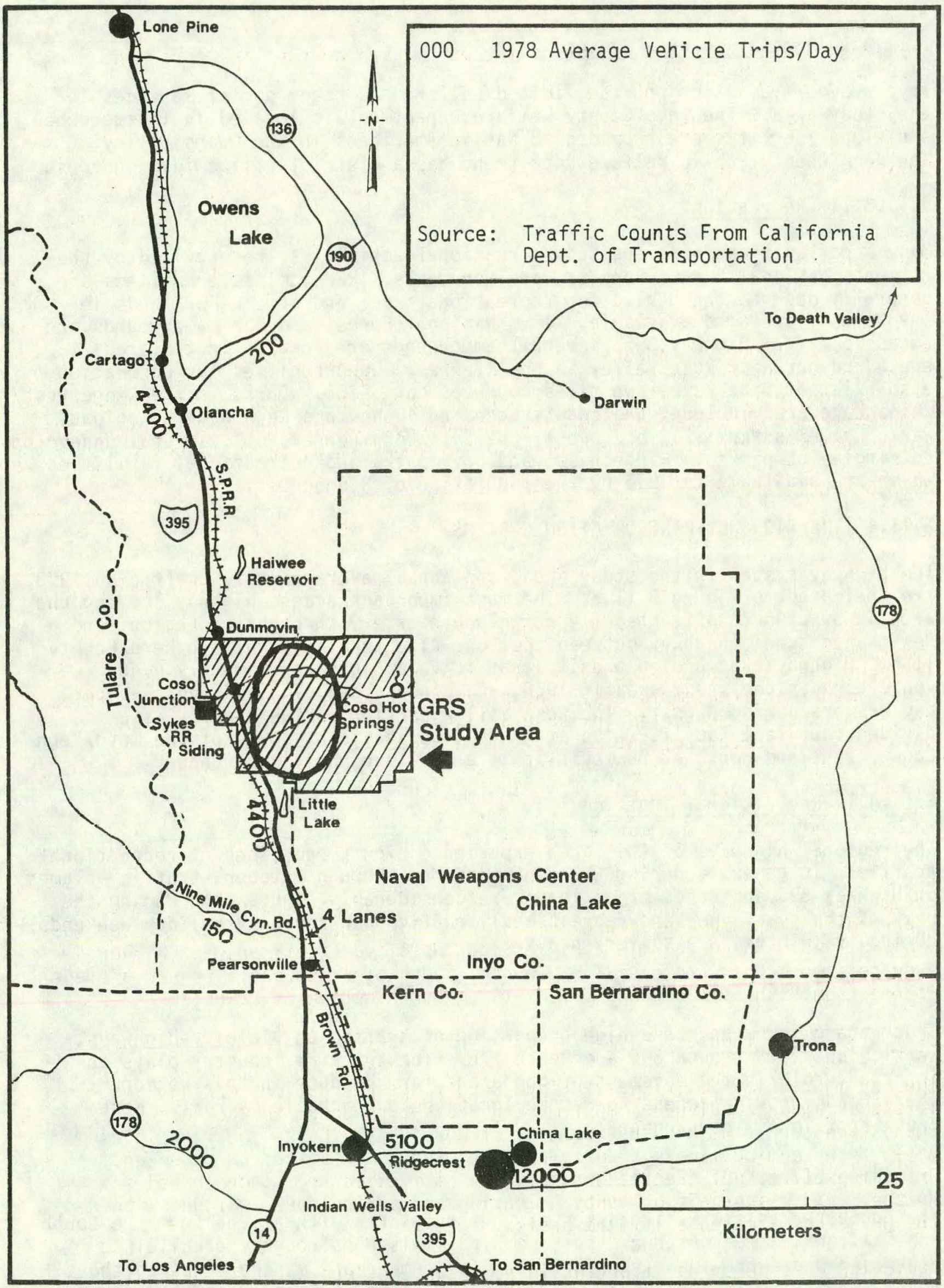

Figure 3.11-2. 1978 ANNUAL AVERAGE DAILY TRAFFIC ON MAJOR ROADS WITHIN STUDY AREA 
in March 1979, advertised notice of intent to abandon the line from Lone Pine to Linnie within three years.

\subsubsection{Public Transportation}

Only limited public transportation is available within the study area. Inyo County presently provides some mini-bus service for the elderly and handicapped. Greyhound Bus has two scheduled round trips daily over U.S. Route 395 and makes stops at Little Lake, Olancha, Lone Pine, Independence, Big Pine, and Bishop.

\subsubsection{Air Transportation}

At present, the only regular, commercial air passenger line operating in Inyo County serves Bishop Airport; however, air charter service is provided to and from various airports, including Bishop and Lone Pine Airports. In the Kern County portion of the study area, two airlines provide scheduled service from Inyokern Airport. A small unused dirt airstrip exists at Coso Junction.

\subsection{1 .5 ECONOMICS}

\subsubsection{Employment}

As indicated in Table 3.11.3, resource industries, government, and trade are the dominant employment sectors in the area, with government accounting for 30 percent of all employment in Ridgecrest in 1970 and 23 percent of al 7 employment in Inyo County in 1977. Military employment at NWC explains the large government sector in Ridgecrest. Mining and recreation comprise the other important area employers. Unemployment data for Inyo and Kern Counties and Ridgecrest is presented in Table 3.11-4. Because Ridgecrest's high government sector employment makes it more directly sensitive to federal budgetary flucuations than to business cycle influences, unemployment in Ridgecrest has tended to be lower than in either Kern County as a whole or Inyo County.

\subsection{1 .5 .2 Income}

Income data for California, Inyo, and Kern Counties, and Ridgecrest were recorded in the 1970 Census and the 1977 Special Census, and are included in Table 3.11-5. The data show that residents of Inyo County enjoy a higher average income than those of Kern County, but Ridgecrest has a higher average income than either. Both counties fall below the state as a whole.

\subsubsection{Major Industry}

The key industrial activities in Inyo County are recreation, mining, and livestock and agriculture. Most mining activities occur in the Lone Pine/ Owens Lake area. Within the vicinity of Rose Valley/Coso, there are a cinder mine, three pumice mines, a pozzolan mine, and some limited tungsten and uranium exploration. Recreation industry activities are concentrated in northern and eastern Inyo County. Grazing and agriculture is found within the GRS study area on a limited basis.

Agriculture is becoming important in northeastern Kern County. Other industrial activity in the Ridgecrest and Inyokern areas largely supports the 
Table 3.11-3. EMPLOYMENT BY SECTOR, 1970 AND 1977

\begin{tabular}{|c|c|c|c|c|c|}
\hline & \multicolumn{2}{|c|}{ Inyo County } & \multicolumn{2}{|c|}{ Kern County } & \multirow{2}{*}{$\frac{\text { Ridgecrest }}{\underline{1970}}$} \\
\hline & 1970 & $\underline{1977}$ & $\underline{1970}$ & $\underline{1977}$ & \\
\hline $\begin{array}{l}\text { Agriculture, Forestry, } \\
\text { Fisheries, Mining }\end{array}$ & 891 & 691 & 20,565 & 36,000 & 250 \\
\hline Construction & 593 & 339 & 7,121 & 5,300 & 163 \\
\hline Manufacturing & 235 & 97 & 8,352 & 8,600 & 145 \\
\hline $\begin{array}{l}\text { Transportation, } \\
\text { Communications and } \\
\text { Utilities }\end{array}$ & 671 & 672 & 7,015 & 6,700 & 239 \\
\hline $\begin{array}{l}\text { Wholesale and Retail } \\
\text { Trade }\end{array}$ & 1,345 & 1,121 & 23,738 & 29,200 & 642 \\
\hline $\begin{array}{l}\text { Finance, Insurance } \\
\text { and Real Estate }\end{array}$ & 158 & 221 & 4,210 & 4,200 & 271 \\
\hline Services & 1,732 & 1,588 & 27,877 & 18,500 & 562 \\
\hline Government & 326 & 1,439 & 10,061 & 31,600 & 1,004 \\
\hline other & -- & $=$ & -- & 8,500 & -- \\
\hline TOTAL & 5,951 & 6,168 & $109 ; 539$ & 148,600 & 3,276 \\
\hline
\end{tabular}


Table 3.11-4 LABOR FORCE AND UNEMPLOYMENT, 1970 AND 1977

\begin{tabular}{|c|c|c|c|c|c|}
\hline & \multicolumn{2}{|c|}{ Inyo County } & \multicolumn{2}{|c|}{ Kern County } & $\frac{\text { Ridgecrest }}{\underline{1970}}$ \\
\hline Civilian Labor Force & 6,292 & 9,225 & 117,390 & 163,000 & 3,435 \\
\hline Unemployment & 341 & 950 & 7,851 & 14,400 & 159 \\
\hline Unempl oyment Rate & $5.4 \%$ & $10.2 \%$ & $6.7 \%$ & $8.8 \%$ & $4.6 \%$ \\
\hline
\end{tabular}

Table 3.11-5. STUDY AREA INCOME LEVELS

\begin{tabular}{|c|c|c|c|c|c|}
\hline \multirow{3}{*}{$\begin{array}{l}\text { Median } \\
\text { Family Income }\end{array}$} & & Inyo County & Kern County & Ridgecrest & Californic \\
\hline & 1969 & $\$ 9,964$ & $\$ 8,937$ & $\$ 11,009$ & $\$ 10,732$ \\
\hline & 1977 & $\$ 11,687$ & $\$ 10,936$ & $\$ 16,077$ & - \\
\hline \multirow{2}{*}{$\begin{array}{l}\text { Per Capita } \\
\text { Income }\end{array}$} & 1969 & $\$ 3,436$ & $\$ 2,823$ & $\$ 3,866$ & $\$ 3,614$ \\
\hline & 1977 & $\$ 4,756$ & $\$ 3,732$ & $\$ 5,392$ & $\$ 5,464$ \\
\hline
\end{tabular}


NWC.. The area is also becoming a regional recreation service center for motorcyclists and other types of recreational vehicles. Forty kilometers east of Ridgecrest in San Bernardino County are Stauffer Chemical Company and Kerr-KcGee Chemical Company, which provide additional stimulus to the economy of northeast Kern County.

\subsubsection{Public Revenues}

A summary of general public revenue sources in Fiscal Year 1977-78 for Inyo and Kern Counties, and for the City of Ridgecrest, is presented in Table 3.11-6. The total general revenues in that fiscal year were approximately $\$ 10.8$ million for Inyo County, approximately $\$ 194.2$ million for Kern County, and approximately $\$ 4.4$ million for the City of Ridgecrest. The net total assessed value for property tax purposes in fiscal year 1978-79 was approximately $\$ 129.5$ million for Inyo County; approximately $\$ 2,848.4$ million for Kern County; and approximately $\$ 42.8$ million for the City of Ridgecrest.

Another major component of the local tax base is sales and use tax. The State of California levies a six percent sales tax on local purchases and provides for a one sixth subvention (one percent of taxable sales) to the County or local community (depending on the point of sales) and one-twenty-fourth subvention ( 0.25 percent of taxable sales) to the County, from the total sales tax collected within it. The total taxable sales in 1977 were approximately $\$ 87.8$ million for Inyo County, approximately $\$ 1,933.2$ million for Kern County, and approximately $\$ 6.3$ million for the City of Ridgecrest.

\subsubsection{Public Expenditures}

A summary of general expenditures for Fiscal Year 1977-78 for Inyo and Kern Counties as well as for the City of Ridgecrest, is presented in Table 3.11.7 Ihe total general public expenditure in Fiscal Year 1977-78 was approximately $\$ 10.9$ million for Inyo County, approximately $\$ 182.5$ million for Kern County, and $\$ 4.7$ million for the City of Ridgecrest.

\subsection{1 .6 PUBL IC ATTITUDES}

On the whole, public attitudes within the study region reflect similar values, concerns, and issues to those found elsewhere in the Great Basin and Mojave regions. The majority of desert residents over the age of 18 moved to the desert from other regions, many for reasons of health, for retirement, or because of job transfer or military assignment; and that the desert environment is perceived as contributing to their well-being. Independence, privacy, recreational opportunities, and aesthetic qualities are all perceived as integral and highly valued aspects of that environment.

Opinion on the issue of further growth in the Indian Wells Valley (IWV) is not united. In the wake of substantial population shifts from NWC to Ridgecrest, additional rapid growth in the City is perceived as presenting problems. The City's current need for physical improvements is stressed in a recent letter by the mayor of Ridgecrest, in which water systems, roads, storm drains, and recreational facilities were cited as needing upgrading for the present level of population. Problems with water delivery and a general lack of services are also seen as serious constraints to further development in the greater IWV area. 
Tabile 3.11-6. SUMMARY OF GENERAL REVENUES: FISCAL YEAR 1977-78

(in thousands)

\begin{tabular}{|c|c|c|c|c|c|c|c|c|}
\hline Area & Taxes & $\begin{array}{l}\text { Licenses } \\
\& \text { Permits }\end{array}$ & $\begin{array}{c}\text { Fixes/ } \\
\text { Penalities }\end{array}$ & $\begin{array}{c}\text { Use of } \\
\text { Money/ } \\
\text { Penalties }\end{array}$ & $\begin{array}{l}\text { From } \\
\text { Other } \\
\text { Agencies }\end{array}$ & $\begin{array}{l}\text { Current } \\
\text { Service } \\
\text { Charges }\end{array}$ & $\begin{array}{l}\text { Other } \\
\text { Revenue }\end{array}$ & Total \\
\hline
\end{tabular}

\begin{tabular}{lcccccccc}
$\begin{array}{l}\text { Inyo } \\
\text { County }\end{array}$ & $\$ 4,024.0$ & $\$ 129.3$ & $\$ 153.2$ & $\$ 173.3$ & $\$ 4,423.0$ & $\$ 1,748.7$ & $\$ 154.4$ & $\$ 10,805.8$ \\
$\begin{array}{l}\text { Kern } \\
\text { County }\end{array}$ & $90,104.2$ & $1,453.6$ & $2,111.9$ & $7,170.7$ & $68,778.5$ & $27,657.5$ & $(3,125.7)$ & $194,150.6$ \\
$\begin{array}{l}\text { City of } \\
\text { Ridgecrest }\end{array}$ & $1,364.2$ & 147.7 & 45.2 & 36.3 & 975.5 & $1,748.9$ & 91.7 \\
\hline
\end{tabular}


Table 3.11-7 SUMMARY OF GENERAL EXPENDITURES: FISCAL YEAR 1977-78

(in thousands)

Category of Services

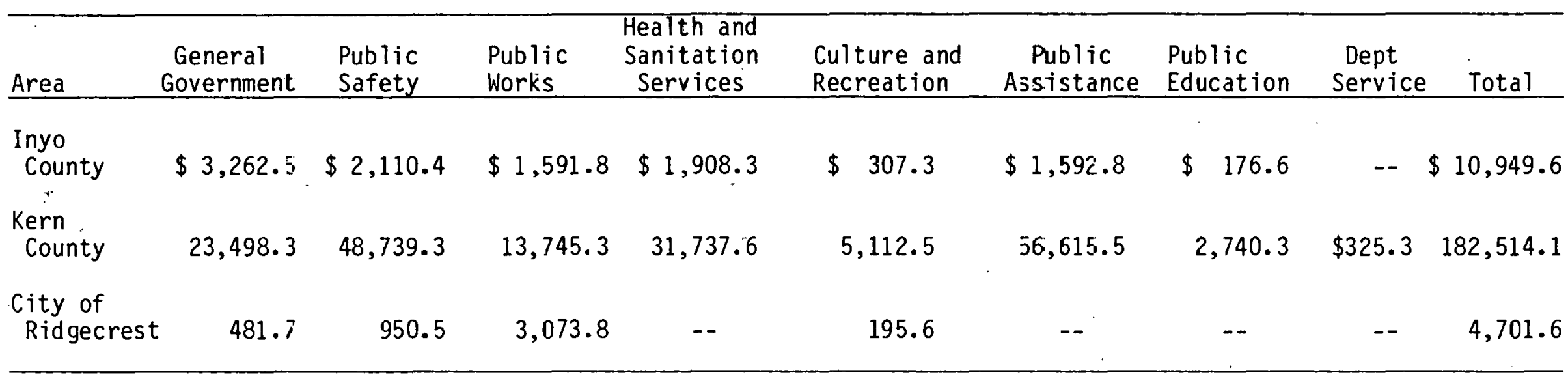


Residents of the Inyo County portion of the study area generally perceive the region's economy as being static. Many young people leave for areas of greater educational and employment opportunity. Population decline is seen as likely to continue; and some anxiety has been expressed regarding the future of recreation and tourism --the area's economic staple-- as a result of fuel unavailability and/or high price. Availability of land is an additional serious concern. Public opinion in the southern portion of the county generally favors growth while the northern, somewhat more urbanized portion favors only limited growth.

At the same time, however, ambivalence toward development is expressed by residents who treasure the existing qualities of life in the area; for example, the loss of a sense of privacy is seen as a negative though necessary outcome of any major development program. In general, these residents appear to perceive a necessity for some substantial broadening of the economic base, even while they regret the changes this would bring. Also to be considered in assessing county-wide public attitudes is the highly publicized controversy over increase in pumping of Owens Valley ground water by the Los Angeles Department of Water and Power. The proposed increase is seen as imposing deliberate constraints on the county's economy, particularly recreation and agriculture/ranching. Countywide opinion seems to support a continuation and enrichment of present lifestyles and values. In the southern Inyo area, this support is no less observable than elsewhere, but here the residents express an acceptance of the need for some industrial infusion, as long as environmental values are preserved.

\subsubsection{NATIVE AMER ICAN CONCERNS}

Recently, increasing attention and concern have been given to Native American problems, attitudes and issues throughout the American Southwest; this is particularly true when large-scale development plans or projects threaten or alter traditional Indian life patterns and beliefs.

There are at present approximately 1,300 Paiute-Shoshone and Northern Paiute Indians living in Inyo County, most of them in or near one of the four reservations at Bishop, Big Pine, Fort Independence, and Lone Pine. These groups have all expressed similar concerns over any potential development of the area surrounding Coso Hot Springs. Their concerns have been publicized in local and regional news media and have been the subject of several anthropological studies. In general, the anxieties expressed by local Indian groups have centered around four issues: (1) possible impacts of development upon the waters or muds at Coso Hot Springs; (2) disturbance, either deliberate (vandalism) or accidental, of archaeological resources --and particularly burial sites; (3) difficulties with regard to access to the Springs and a nearby Prayer Site for medicinal and religious purposes; and (4) once access may have been gained, the prospect of having their ceremonies interrupted by traffic, noise, or the presence of workmen. See Figure 3.10-2 for location of these sensitive areas within the GRS study area.

There appears to be sufficient evidence that Paiute-Shoshone peoples traditionally frequented the Springs, and that they attributed medicinal values to the waters and muds. Many local Native Americans attest to this and also to the religious significance of the area for their ancestors, citing creation myths and other folklore connected with the Springs and giving personal recollections of trips made there for. religious rituals and for use of the 
healing muds. This traditional use was constrained by development of a commercial spa at Coso Hot Springs in the early 1920s, and in 1943 by the withdrawal of the area from public use as part of the NWC. In intervening years the Navy has, when possible, accommodated Native American groups wishing to visit the site; however, it is clear that unrestricted access is incompatible with the NWC mission. Recently, an agreement has been reached between the Navy and Owens Valley Paiute-Shoshone Indians, guaranteeing eight scheduled overnight visits per year (and additional visits on request) during which Indians will have exclusive use of the area immediately surrounding the Springs and Prayer Site.

It is difficult for members of Western civilizations to comprehend the traditional Indian view of the earth as universal life-giver and healer, and equally difficult for traditional Indians to grasp the prevailing civilization's view of land as something that can be bought and sold, by private or public entities. This is only one instance of the wide divergence in value systems. Many of today's Native Americans have bridged the gap and can particinate in both value systems to some extent, but this is an effort; and they feel it is an ettort few Anglo-Americans are willing to make. For most of the elders, Western values are seen as an imposition of the majority upon the minority, which they accept in resignation. It is the feeling of researchers that many of the Native Americans are resigned to development. They hope that the government will respect their values as members of a plural society, will give their cultural and archaeological resources all possible protection, and will give their people a prominent voice in planning multiple uses of public lands. These views, however, are not necessarily those of all, or the younger, members of these tribes.

\subsection{CULTURAL RESOURCES}

Because of the long-term human occupance (perhaps as much as 50,000 years) and environmental conditions conducive to preservation of evidence of that occupance history, the Basin and Range Province is generally characterized as having archaeological/cultural resources of considerable significance, interest, and sensitivity. Certainly this is true of the GRS site and vicinity. This section briefly summarizes what is known of the prehistory,ethnography, and archaeological significance of the GRS study area. The history of the area since 1860 is briefly sketched and the results of a recent archaeological survey of the area of Rose Valley are summarized.

\section{$3.1 \% .1$ PREHISTORY}

Human use of the Rose Val ley area began during the Paleo-Indian period, more than 10,000 years ago. Evidence at China Lake suggests that aboriginal hunters regularly traversed the area. Definite cvidence of ancient huilidl use of the area has been found at Little Lake; this evidence dates back to at least 4,000 years ago, when a hunting and gathering subsistence pattern had evolved in the area. This period corresponds to what is known as the Western Lakes Pluvial Tradition, a period in which much of California and the Great Basin was characterized by lakes resulting from the run-off from glaciers, and by the generally wet climatic conditions at the end of the Pleistocene Period. These early environmental conditions provided a habitat that was very favorable in terms of human occupation, and it is possible that the aboriginal population in the area was then as large as, or larger than, at any other time. 
Judging from the works of numerous researchers in this area, aboriginal use of the region appears to have been continuous from this period until the arrival of Anglo-Americans in the 19th Century. However, the intensity of use of the area very probably changed as the environment shifted toward the arid regime now characterizing the Mojave Desert and Great Basin. Archaeological evidence from the region, in general, indicates an increasing emphasis on the exploitation of plant resources other than those associated with streams and lakeshores.

Many researchers believe that at some-point during the prehistory of the Rose Valley area, the Coso Range may have functioned as the focus of what has been interpreted as a hunting cult, which appeared to emphasize the exploitation of bighorn sheep and which probably was at its apex between 3000 and 1000 B.C. The remnants of the hunting magic apparently associated with this cult are the numerous rock art sites, characterized by petroglyphs, or pecked designs, of bighorn sheep and hunters, covering basaltic rock outcrops and the walls of canyons in Rose Valley and the Coso Mountains.

Another important factor in the prehistory of the area is the existence of a major obsidian source at Sugarloaf Mountain, just east of the rectenna site. obsidian was the primary (and preferred) material for aboriginal stone tools made in this general region. The obsidian from this location was used in. the manufacture of all types of stone tools and implements by various aboriginal groups, Evidently the resource was not claimed exclusively by the inhabitants of the immediate vicinity; rather, the area seems to have been regarded as a "free zone," where peoples from other areas could mine the obsidian as needed. This contributed to an unusual amount of prehistoric traffic into the area and to a subsequent rich and varied archaeological record.

\subsubsection{ETHNOGRAPHY AND HISTORIC PERIOD}

The ethnographic period is that period, after the arrival of white settlers, during which the aboriginal inhabitants followed, to some degree, their traditional lifeways. Research indicates that the study area was inhabited by the Koso or Panamint Shoshone-speaking peoples. Rose Valley was part of the Kuhwiji district, which was a portion of a large subsistence area which may have included Saline Valley, Owens Lake, the Sierras and even Death Valley. The Rose Valley area was a specific unit within that area which was used during the periods of the year when its resources were most abundant; for example, rabbits in winter, tender vegetation and greens at Little Lake and Haiwee Spring in Spring. Major villages are thought to have existed at at Little Lake, Coso Hot Springs, and Olancha.

In addition to the use of the GRS site and vicinity for habitation (at Coso Hot Springs and Little Lake), for ceremonial activities (at rock art sites), for obsidian quarrying (Sugarloaf Mountain) and other seasonal hunting and gathering activities, Coso Hot Springs was apparently the site of aboriginal medicinal and ceremonial rituals at the time of the arrival of white inhabitants in the area. The religious use of the Coso Hot Springs by local Native Americans has continued to the present. Of interest in the historic period is the commercial development of the Coso. Hot Springs that began around 1909 and continued, with minimal commercial success until the acquisition of the property by the Navy in 1943. 
In summary, Rose Valley and its surroundings is characterized by a basic archaeological record analogous to that found throughout the Great Basin. That is, there is evidence of a continuous but changing aboriginal habitation and utilization of the region starting at least by 12,000 B.C. and continuing into the historic period. However, natural and cultural factors combined to produce unique archaeological conditions. Sugarloaf Mountain, a major source of obsidian, may have been the impetus for obsidian quarrying and appears to have resulted in an unusual intensity of activity and trade in the area. Rock art sites in the area indicate the probable existence of hunting cults and ceremonial spots. Finally, it is conjectured that Coso Hot Springs was apparently known and utilized as a medicinal and ceremonial focus for the aboriginal inhabitants of the region.

\subsubsection{CULTURAL RESOURCES INVENTORY}

A cultural resources inventory of about 33,500 hectares that includes the GRS site and vicinity was performed in the winter of 1978-79. Fifty-seven sites (including the National Historical Register sites at Coso Hot Springs and the Prayer Site) had previously been recorded within the area by other researchers; an additional 139 previously unrecorded sites were located during the recent survey. The majority of these sites (55 percent) were classified as lithic scatters (areas where stone tools or chips from tool construction are found). The large number of sites can, in part, be attributed to the presence of the obsidian source at Sugarloaf Mountain; it is clear that the presence of obsidian contributed to a high intensity of aboriginal use of the area. It is estimated that an average density of 1.7 sites per square kilometer would characterize the entire 32,500 hectare archaeological study area. Within the GRS site in Rose Valley this density would result in a total of nearly 250 sites, covering as much as 50 percent of the ground area. However, using such average density figures produces questionable results. Because less than 12 percent of Rose Valley itself was sampled, it is difficult to estimate the actual number of sites present. Further complicating matters is the lack of random distribution of the sitcs themselves; few sites were located in the northern part of the valley or around the margins of playas, while the southern part of the valley was found to be virtually one vast, continuous site consisting of lithic scatters, hunting camps, and shelters. This area of great density, covering more than 370 hectares, has been nominated to Historic Register status as the Fossil Falls Archaeological District. Such site density is atypical of the entire region and the Basin and Range province as a whole; however, this concentration is not unusual for areas of particular attraction to aboriginal populations.

The Coso Hot Springs and Prayer Site, (neither of which are within the GRS site), are listed on the National Register of Historic Places. The study area, with its wide range of sites and long span of aboriginal occupation, has a potential for the investigation of a number of research questions which may be related to broader, regional problems in archaeology. It is an area of contact of several major cultures and has provided a long-used corridor for the movement of people, trade goods and ideas among inland and coastal areas of California. Thus the archaeology of the Coso area could have implications for the interpretation of the archaeological record in other areas. 


\subsection{VISUAL RESOURCES}

The landscape of the GRS site and its surroundings is typical of that found throughout the Basin and Range Province. This section contains a description and analysis of the visual resource aspects of that landscape.

\subsubsection{LANDSCAPE CHARACTER}

All landscapes have an identifiable character, regardless of size, location, or land use. Landscapes that possess or have potential for a greater degree of visual variety are generally considered more desirable than those that tend to be monotonous. The character of a landscape is determined by the features that are seen and their arrangement in the landscape composition. Features can be divided into three categories: land and water surface, vegetation, and structures. Four basic elements define a particular feature: form, line, color, and texture. The more elements there are in the landscape which exert a strong visual influence or contrast, the stronger or more interesting the landscape character. The degree of variety and harmony among the basic elements determines whether or not a given landscape is pleasant to view.

\subsubsection{VISUAL RESOURCES INVENTORY}

The study area includes Rose Valley, from Little Lake north to Dunmovin (a distance of roughly $19 \mathrm{kilometers}$ from north to south), and the visual framework provided by the foothills of the Sierra Nevada to the west and the Coso Range to the east (a distance of approximately 16 kilometers). Notable landscape features within the study area include the Rose Valley basin, a basalt field in the southern portion of Rose Valley, alluvial fans on the eastern edge of the valley, and the interior valleys of the Coso Range. The Rose Valléy portion of the study area is flat, with a covering of gray-green scrub vegetation. A small amount of cropland, several small settled areas, a few mines, two power transmission lines, and the Los Angeles Aquaduct comprise the cultural features of the valley landscape. Light and dark patterns of vegetation can be seen on the adjacent foothills, and mountain ranges are apparent beyond the foothills. (See Figure 1.4-3 which is a photograph of the Rose Valley area.)

Through the use of the concepts underlying the Bureau of Land Management's (BLM) Visual Resources Management (VRM) methodology, classifications for the various portions of the study area were developed. The BLM methodology includes ratings based on the visual prominence (i.e., the degree to which intrusions would be visible in the landscape), visual sensitivity, and scenic quality of the landscape (see Table 3.13-1). These ratings are then combined in a classification system from $\mathrm{Cl}$ ass $\mathrm{I}$ to $\mathrm{V}$ as the highest preference value and Class $V$ as the lowest. Class I applies primarily to primitive and natural areas; Class $V$ applies to areas where the natural character of the landscape has been disturbed so severely that rehabilitation is needed to bring it back into character with the surrounding landscape. Classes II, III and IV represent incremental gradations between the two extremes of the scale. As shown in Figure $3.13-1$, the entire study area can be classified by VRM classes II, III and IV. 
Table 3.13-1. BLM VISUAL RESOURCE CLASSIFICATION SYSTEM

Class I. This class provides primarily for natural ecological changes only. It is applied to designated primitive areas, some natural areas, and other similar situations where management activities are to be restricted.

Class II. Changes in any of the basic elements (form, line, color or texture) caused by a management activity should not be evident in the characteristic landscape.

Class 1II. Changes in the basic elements (form, line, color and texture) caused by a lldallyement activity may be evidenl in the characteristic landscarpe. However. the changes should roma in suliurdillate to the visual strength of the existing character.

Class IV. Changes may subordinate the original composition and character but will reflect some basic elements of the character type.

Class $V$. Change is needed. This class applies to areas where the natural character has been disturbed to the point where rehabilitation is needed to bring it back into character with the surrounding countryside. This class would apply to areas identified in the scenery evaluation where the quality class has been reduced because of unacceptable intrusions. It should be considered an interim, short-term classification until one of the other objectives can be reached through rehabilitation or enhancement. The desired visual quality objective should be identified. 


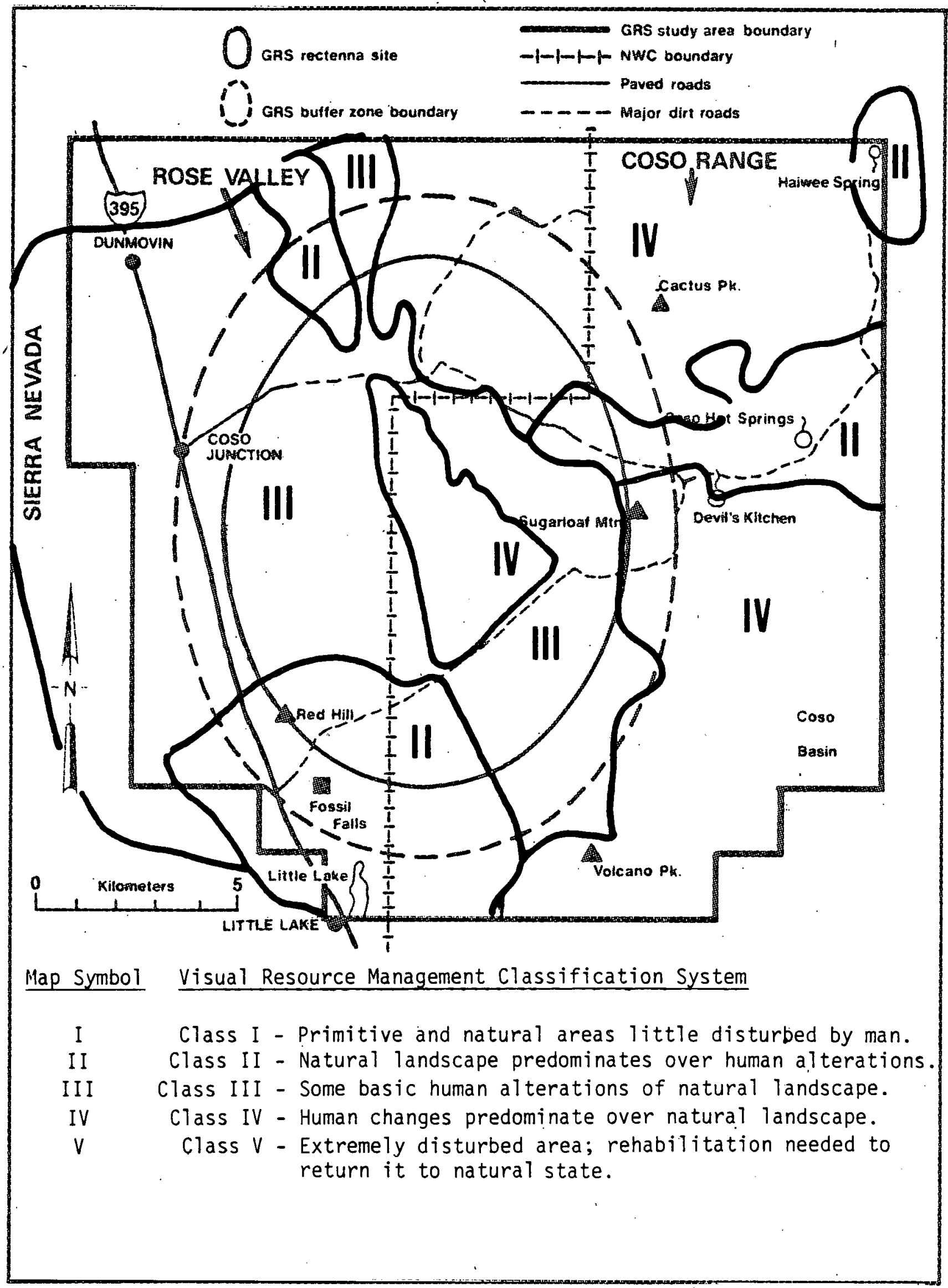

Figure 3.13-1. GENERALIZED VISUAL RESOURCE INVLNTORY OF THE GRS STUDY AREA 
The existing visual character of Rose Valley is rated Class III, indicating a low scenic quality, generally lacking in variety, with widespread but insignificant intrusions (such as settlements, transmission lines, and other cultural features previously described). However, the view of the foothills to the east and west of the valley lends interest to the landscape. Both the Rose Valley basalt field and most of the Coso Range interior valleys that are included in the study area are rated Class II, due to the variety and uniqueness of the landforms. The Rose Valley alluvial fan area and much of the Coso Range is rated Class IV - poor scenic quality - as there is little variety, uniqueness, or color in the scenery. The study area as a whole is generally lacking in outstanding or dramatic visual features.

\subsection{ELECTRICITY SUPPLY AND DEMAND}

Prior to the 1973 Arab oil embargo, California electricity demand grew at an annual rate of 7 to 9 percent, but since 1974, growth rates have been in the 3 to 5 percent range. The recent OPEC price increases may reduce the longrun electrcity growth rate if the oil price increases result in a significant increase in the price of electricity. Statewide projections of future electricity growth by the California Energy Commssion, electric utilities, and private consultants have been in the 3.5 to 4.5 percent range. This report has assumed an annual electricity growth rate of 4.1 percent for electricity sales and 4.0 percent annual growth rate of peak demand for the State of California; such a growth in peak demand would require a doubling of electrical generating capacity from 38,000 megawatts in 1977 to 73,200 megawatts in 1995.

In 1977 California's electrical demands were satisfied with electricity generated from natural gas (25 percent), coal (10 percent), oil (46 percent), nuclear ( 6 percent), geothermal ( 5 percent), and hydroelectric ( 7 percent). Only 83 percent of the electricity used in California is generated in California; the remainder, including all of the coal-produced electricity and one-half of the hydroelectric power, is generated out of state. The electricity generated for California (in and out of state) is still dominated by gas and oil-powered plants (72 percent); this dependence should decrease over time due to legislative mandates and increasing costs of $0 i 1$ and gas. The Power Plant and Industrial Fuels Act of 1978, a part of the 1978 federal energy legislation, requires that electric utilities phase out gas and oil-powered generating facilities by 1990 (2000 under certain conditions).

Coal, nuclear, geothermal and solar can all be seen as competing for a portion of this demand as well as providing a diversified generating capacity that is not dependent on a single fuel. The stated intentions of the Carter Administration to provide stimulus for alternative fuels (e.g., solar, biomass, wind) may make these generating techniques also viable in the future. The type of generating capacity chosen will depend upon capital costs, fuel prices, and regulatory constraints. Conservation techniques are al so expected to reduce actual capacity required. 


\subsection{ENVIRONMENTAL IMPACTS}

\subsection{INTRODUCTION}

The following chapter describes the expected environmental impacts of GRS siting and construction on the natural and human environment of the Rose Valley/Coso study area. Potential measures to mitigate adverse impacts also are identified and briefly discussed.

The impacts of developing the electric power transmission system to connect the GRS with the utility interties are not included in the individual impact area discussions (e.g. air quality, noise). Transmission system development would occur almost entirely outside the GRS site, with impacts spread along the entire transmission route. However, Section 4.13 presents a very brief discussion of the generic impacts of electric power transmission line development.

As discussed in Chapter 1, in the geology and soils area, environmental implications are more in the nature of environmental constraints (i.e. the impact of the environment on the GRS) than the impacts of the GRS on the geologic environment. The kinds of constraints that local geologic and soils conditions might impose on SPS GRS development are briefly described in Section 4.4 .

It must be noted that the following impact assessment is not intended to serve as a formal (in terms of applicable federal statutes, such as the National Environmental Policy Act of 1969) Environmental Statement. GRS design is not.yet sufficiently complete to permit the thorough and detailed assessment that ultimately will be required when formal GRS siting proposals are developed. Rather, the purpose of this impact assessment is to identify critical impact areas and to give order of magnitude impact data to serve as inputs to the overall SPS Concept Development and Evaluation Program and specifically to the ongoing process of GRS design and development.

Throughout the impact assessment we have attempted to be conservative, to estimate the maximum impacts of GRS development. Thus, within the framework of the GRS descriptive data presented in Chapter 2, we have used scenarios where, for example, the geographic location within the GRS site and coincidence (in terms of timing) of various GRS development activities would maximize impacts.

It also should be noted that the impact assessments are based on existing technology (e.g. fuel use and air emission rates for current vehicles and equipment) and current legal standards. For example, to the extent that future technological developments improve vehicle/equipment combustion efficiency or enission control equipment, it is likely that GRS construction air pollutant emissions would be reduced, thereby reducing project air quality impacts. 


\subsection{AIR QUALITY/CLIMATOLOGY}

\subsubsection{INTRODUCTION}

The following sections discuss the emissions sources, estimates of the magnitude of potential air pollutant emissions, and the potential impacts of GRS development on the ambient air quality of the study area. In addition, potential GRS climatological impacts are briefly discussed.

Developing an air quality analysis that encompasses all GRS construction and operation activities requires the integration of large amounts of data. Given the intended use of this study (see Section 4.1) and the limited resources available, only the potential maximum emissions and impacts are estimated. In order to accomplish this task, adoption of some simplifying assumptions were inevitable. Consequently, the data provided in this section are intended to show relative magnitudes and distributions rather than exact representations of expected emissions and impacts.

Section 4.2.2 presents an emission inventory for the peak activity period of the GRS project. The inventory presents total hydrocarbons (THC), nitrogen oxides $\left(\mathrm{NO}_{\mathrm{X}}\right)$, sulfur oxides $\left(\mathrm{SO}_{\mathrm{x}}\right)$, carbon monoxide $(\mathrm{CO})$ and particulate matter (PM) emissions. A detailed description of emission sources and appropriate emission factors associated with these sources are presented in this section.

The impact of the estimated emissions on the air quality of the study area are calculated in Section 4.2 .3 , based on standard air quality modeling techniques. Incremental concentrations of pollutants due to the proposed project are compared with the existing ambient air quality and federal and state Ambient Air Quality Standards (AAQS).

\subsubsection{EMISSIONS INVENTORY}

Based on GRS construction data (e.g. equipment and labor requirements, construction schedule) presented in Chapter 2 of this report (Description of the Proposed Action), Months 9 to 11 of the GRS construction period appear to have the highest level of construction activity, and consequently, the highest levels of emissions. Activities that would occur during this period include: site clearing and grading; support structure manufacture and installation; concrete plant operation; construction material transportation, handling and storage; and power collection system construction.

Major sources of emissions associated with each activity, along with operational characteristics of these sources (such as fuel consumption and load factors) are presented in this section. Current emission factors for each type of equipment also are listed. Then, based on operational characteristics and emission factors, calculations of maximum daily and hourly emissions associated with each type of equipment are presented.

\subsubsection{Site Clearing and Grading}

It is estimated that 600 pieces of heavy-duty construction equipment would be required on a daily basis during GRS site clearing and grading operations, although five percent of this equipment is expected to be on standby. Emission 
factors associated with each type of equipment are presented in Table 4.2-1. Maximum daily and hourly emissions associated with site clearing and grading are presented in Table 4.2-2.

As shown in Table 4.2-2, a significant amount of fugitive dust may be emitted during this construction phase. Dust emissions are based on an emission factor of 0.36 tonnes of dust per hectare per month as presented in EPA publication AP-42 (U.S. EPA, 1975). This emission factor assumes a medium activity level, moderate silt content of the soil, and semiarid climate. The actual fugitive dust associated with the GRS project may differ based on the level of activity, soil characteristics, climate of the specific site, and the means used to control fugitive dust emissions.

\subsubsection{Support Structure Manufacture and Installation}

The rectenna support structure manufacture and installation phase is expected to require approximately seven months (Months 9 to .15). During this period, a detailed survey of the site must be accomplished; concrete footings for each rectenna support structure must be emplaced; and the support structures themselves must be manufactured and then installed in the foundations. The onsite concrete plant is assumed to provide the required concrete for these operations.

Emission factors associated with the required construction equipment are presented in Table 4.2-3. Maximum daily and hourly emissions associated with support structure manufacture and installation are presented in Table 4.2-4. It is assumed that most of the concrete plant equipment is electrically powered. Emissions associated with power generation are discussed in Section 4.2.2.5.

\subsubsection{Transportation of Construction Materials}

GRS construction would require the delivery of substantial amounts of material and equipment to the site. Bulk shipment of materials to the construction site will be at its peak during Months 9 to 15. For emission calculation purposes it is assumed that a mix of both track and rail transportation will be employed. Seventy percent of material is assumed to be transported by rail and the remaining thirty percent by truck.

Locomotive and truck emission factors are shown in Table 4.2-5; emissions associated with rail and truck transport are shown in Tables 4.2-6 and 4.2-7. Several assumptions were needed to estimate these emissions. Locomotive horsepower requi rements vary between 0.45 to 2.7 horsepower (hp) per tonne of train capacity (UCLA, 1978). A value of $1.8 \mathrm{hp}$ per tonne is assumed for this study. Based on a total capacity of 9,100 tonnes/train (100 car $\times 91$ tonnes) car) total power requirements for a train would be 18,200 hp. Current 10c0motives are rated at approximately 3,000 hp (UCLA, 1978). Therfore, six locomotives were assumed to be required by each train.

The maximum daily train emissions presented in Table 4.2-6 only represent pollutants emitted while the train is within the confines of the GRS site. It assumes a half-hour train visit as it approaches the delivery area with an average speed of $16 \mathrm{kilometers} \mathrm{per} \mathrm{hour} \mathrm{(an} \mathrm{8-km} \mathrm{stretch);} \mathrm{a} \mathrm{half-hour} \mathrm{required}$ for unloading the train; and a.half-hour for the train's departure (8-km 
Table 4.2-1. EMISSION FACTORS FOR HEAVY-DUTY CONSTRUCTION EQUIPMENT

\begin{tabular}{|c|c|c|c|c|c|c|c|}
\hline \multirow[b]{2}{*}{ Source } & \multirow{2}{*}{ 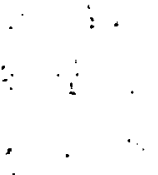 } & \multicolumn{6}{|c|}{ Emission Factors $\left(\mathrm{kg} / 10^{3}\right.$ liter fuel) } \\
\hline & & THC & ${ }^{N 0} x_{x}$ & . & $\mathrm{SO}_{\mathrm{x}}$ & $\mathrm{CO}$ & PM \\
\hline Bulldozer & & 2.5 & 53.9 & & 3.7 & .7 .9 & 1.8 \\
\hline Grader &.$\quad \cdots$ & 2.1 & 44.8 & $\therefore$ & 3.7 & 9.4 & 2.7 \\
\hline Dump Truek. & $\therefore$ & 3.6 & 62.8 & & 3.7 & 11.1 & 2.1 \\
\hline Crane & . & 4.2 & 59.2 & & 3.7 & 11.8 & 3.6 \\
\hline Backhoe & & 4.2 & 59.2 & & 3.7 & 11.8 & 3.6 \\
\hline
\end{tabular}

Source: U.S. EPA AP-42 (January, 1975). 
Table 4.2-2. MAXIMUM DAILY AND HOURLY EMISSIONS ASSOCIATED WITH RECTENNA SITE CLEARING AND GRADING.

\begin{tabular}{|c|c|c|c|c|c|c|c|}
\hline \multirow[b]{2}{*}{ Source } & \multirow[b]{2}{*}{ Quantity 1} & \multirow{2}{*}{$\begin{array}{l}\text { Fuel Consumption } 1 \\
\left(10^{3} \text { liters/day }\right)\end{array}$} & \multicolumn{2}{|r|}{ Emissions ${ }^{2}$} & \multicolumn{2}{|c|}{$\mathrm{kg} /$ day $(\mathrm{kg} / \mathrm{hr})^{3}$} & \multirow[b]{2}{*}{ PM } \\
\hline & & & THC & $\mathrm{NO}_{\mathrm{X}}$ & $\mathrm{SO}_{x}$ & $\mathrm{CO}$ & \\
\hline Bulldozer & 131 & 98 & $244(31)$ & $5,309(664)$ & $356(45)$ & $777(97)$ & $174(22)$ \\
\hline Road Grader & 176 & 132 & $276(35)$ & $5,939(742)$ & $494(62)$ & $1,239(155)$ & $353(44)$ \\
\hline Dump Truck & 131 & 98 & $354(44)$ & $6,181(773)$ & $368(46)$ & $1,088(136)$ & $209(26)$ \\
\hline Crane & 89 & 68 & $284(35)$ & $4,034(504)$ & $255(32)$ & $802(100)$ & $246(31)$ \\
\hline Backhoe & 45 & -- & $142(18)$ & $2,017(252)$ & $127(16)$ & $=401(50)$ & $123(15)$ \\
\hline Fugitive Dust & -- & -- & -- & -- & -- & -- & $78,260(0,783)$ \\
\hline TOTAL & & & $300(163)$ & $3,480(2,935)$ & $680(201)$ & $4,307(538)$ & $79,305(9,921)$ \\
\hline
\end{tabular}

1. Quantity and characteristics of each equipment are listed in Chapter 2.

2. Based on emission factors presented in Table 4.2-1.

3. Assumes eight hours of operation per day. 
Table 4.2-3. EMISSION FACTORS FOR EQUIPMENT TO BE USED IN SUPPORT STRUCTURE MANUFACTURE AND INSTALLATION

\begin{tabular}{|c|c|c|c|c|c|}
\hline \multirow[b]{2}{*}{ Source } & \multicolumn{3}{|c|}{ Emission Factors } & \multicolumn{2}{|c|}{$\left(\mathrm{kg} / 10^{3} \text { 1iter }\right)^{1}$} \\
\hline & THC & $\mathrm{NO}_{\mathrm{X}}$ & $\mathrm{SO}_{\mathrm{x}}$ & $\mathrm{CO}$ & PM \\
\hline Auger-Jackhammer & 4.2 & 59.2 & 3.7 & 11.8 & 3.6 \\
\hline Drill (Air Compressor) & 4.5 & 56.2 & 3.7 & 12.2 & 4.0 \\
\hline Concrete Pouring Machine & 4.2 & 59.2 & 3.7 & 11.8 & 3.6 \\
\hline Truck (Concrețe, otther) & 3.6 & 62.8 & 3.7 & 11.1 & 2.1 \\
\hline Arch Factory Equi pment & 4.5 & 56.2 & 3.7 & 12.2 & 4.0 \\
\hline Crane & 4.5 & 56.2 & 3.7 & 12.2 & 4.0 \\
\hline $\begin{array}{c}\text { Concrete Plant } \\
\vdots\end{array}$ & - & -- & -- & -- & $0.012^{1}$ \\
\hline
\end{tabular}

Source: U.S. EPA AP-42 (1975).

1. The units for all the emission factors are $\mathrm{kg} / 10^{3}$ liter fuel except for concrete plant particulates which are in $\mathrm{kg} / \mathrm{m}^{3}$ of concrete. 
Table 4.2-4. EMISSIONS ASSOCIATED WITH SUPPORT STRUCTURE MANUFACTURE AND INSTALLATION

\begin{tabular}{|c|c|c|c|c|c|}
\hline & - & Fuel & Total Fuel & Emissions ${ }^{2} \mathrm{~kg} /$ day $(\mathrm{kg} / \mathrm{hr})$ & . \\
\hline Source & Quantityl & $\begin{array}{l}\text { Consumption } \\
\text { liter/day }\end{array}$ & $\begin{array}{l}\text { Consumption } \\
\text { liters/day }\end{array}$ & THC $\quad \mathrm{NO}^{\mathrm{X}} \quad \mathrm{SO}_{\mathrm{X}}$ & $\mathrm{CO}$ \\
\hline
\end{tabular}

A. Emplacement of Footings

Auger-Jackhammer Rock Drilling

Machine

250

$\begin{array}{rrrrrrr}704 & 176,000 & 732(122) & 10,424(1,737) & 659(110) & 2,072(345) & 634(106) \\ 204 & 612 & 3(0.5) & 35(6) & 3(0.5) & 8(1) & 3(0.5) \\ 272 & & 1 & & & & \\ 522 & 54,400 & 226(38) & 3,229(538) & 204(34) & 642(107) & 196(33) \\ & 46,980 & 169(28) & 2,954(402) & 177(29) & 520(87) & 95(16)\end{array}$

Concrete Pouring

Mach ine

3

704

Concrete Trucks

$200 \quad 272$

$90 \quad 522$

B. Arch Manufacture and Installation

Arch Factory
Trucks
Cranes
Concrete

$\begin{array}{rr}10 & 1,158 \\ 63 & 91 \\ 60 & 658 \\ 3 & 522\end{array}$

$\begin{array}{rcr}11,580 & 59(9) & 651(108) \\ 5,783 & 22(4) & 397(66) \\ 39,480 & 180(30) & 2,251(375) \\ -1,566 & 5(1) & 98(16)\end{array}$

$44(7)$
$24(4)$
$150(25)$
$5(1)$

$\begin{array}{cc}142(24) & 46(8) \\ 71(12) & 14(2) \\ 490(82) & 161(27) \\ 16(3) & 3(0.5)\end{array}$
C. Concrete Plant $^{3}$

1

$-$

$--$

$-$

$-$

$--\quad 1,375(172)$

TOTAL

$1,389(232) \quad 20,039(3,338) \quad 1,266(210) \quad 3,961(661) 2,527(338)$

1. Based on data presented in Chapter 2.

2. Based on emission factors presented in Table 4.2-3. Assumes 6 hours of usage per day for each source except for concrete plant which assumes usage of 8 hours per day.

3. Assumes 23,700 cubic meters of concrete production per day. 
Table 4.2-5. LOCOMOTIVE AND TRUCK EMISSION FACTORS

\begin{tabular}{lcc}
\hline & \multicolumn{2}{c}{ Emission Factors } \\
\cline { 2 - 3 } Pollutant & Locomotive $(g / h p-h r)$ & Truck $(g / h r)$ \\
\hline $\mathrm{THC}^{1}$ & 2.2 & 198 \\
$\mathrm{NO}_{\mathrm{X}}^{1}$ & 10 & 3,460 \\
$\mathrm{SO}_{\mathrm{X}}^{2,3}$ & 2.6 & 206 \\
$\mathrm{CO}^{1}$ & 4.1 & 610 \\
$\mathrm{PM}^{2}$ & 1.2 & 116 \\
\hline
\end{tabular}

1. Source: U.S. EPA, "Compilation of Air Pollutant Emission Factors," AP-42, Third Edition, Table 3.2.2-2, 1978. Assumes 4-stroke road locomotives.

2. Derived from Tables 3.2.2-1 and 3.2.2-2 in the above source.

3. Based on a fuel sulfur content of 0.4 percent. 
Table 4.2-6. MAXIMUM DAILY EMISSIONS ASSOCIATED WITH THE DELIVERY OF CONSTRUCTION MATERIALS

\begin{tabular}{|c|c|c|c|c|c|c|}
\hline \multirow[b]{2}{*}{ Activity } & \multirow[b]{2}{*}{ Quantity } & \multicolumn{5}{|c|}{ Emissions kg/day } \\
\hline & & THC & ${ }^{N O} x$ & $\mathrm{SO}_{\mathrm{X}}$ & $\mathrm{CO}$ & $\begin{array}{l}\overline{P M} \\
\therefore .\end{array}$ \\
\hline Train 1 & 4 & 95 & 432 & 112 & 177 & 52 \\
\hline Truck 2 & 720 & 143 & 2,491 & 148 & 439 & $84^{\circ}$ \\
\hline TOTAL & & 238 & 2,923 & 260 & 616 & 136 \\
\hline
\end{tabular}

1. Assumes 6 locomotives per train, 3,000 hp/locomotive, 0.4 load factor,? and emission factors presented in Table 4.2-5. One-third of the total emissions associated with trains are assumed to be from stationary sources (train unloading at the site). Two-thirds of emissions are assumed to be emitted while train is approaching or departing the site with a speed of $16 \mathrm{kilometers/hour.} \mathrm{These} \mathrm{portions} \mathrm{of} \mathrm{emissions} \mathrm{are}$ assumed to be dispersed along a 8-kilometer stretch south of the unloading site.

2. Assumes 20 minutes for unloading/maneuvering at the site (stationary), 20 minutes approaching the site and 20 minutes departing the site for each truck load per day (mobile). Emissions associated with the mobile sources are assumed to occur in a $10 \mathrm{kilometer} \mathrm{stretch} \mathrm{from} \mathrm{the} \mathrm{loading}$ site. Emissions associated with stationary sources are one-third of total emissions. 
Table 4.2-7. MAXIMUM HOURLY EMISSIONS ASSOCIATED WITH THE DELIVERY OF CONSTRUCTION MATERIALS

\begin{tabular}{|c|c|c|c|c|c|c|}
\hline \multirow{2}{*}{ Activity } & \multirow[b]{2}{*}{ Quantity } & \multicolumn{3}{|c|}{ Emissions $\mathrm{kg} / \mathrm{hr}$} & \multirow[b]{2}{*}{$\mathrm{CO}$} & \multirow[b]{2}{*}{$\overline{P M}$} \\
\hline & & THC & $\mathrm{NO}^{\mathrm{x}}$ & $\mathrm{SO}_{\mathrm{x}}$ & & \\
\hline Train & 1 & 16 & 72 & 19 & 30 & 9 \\
\hline Truck & 30 & 6 & 104 & 6 & 18 & 3 \\
\hline TOTAL & & 22 & 176 & 25 & 48 & 12 \\
\hline
\end{tabular}

1. Based on emission factors presented in Table 4.2-5. 
stretch). Based on the materials requirements estimated in Chapter 2 , and a 70:30 rail/truck mix, four trains would be required daily during the peak activity period.

Truck emissions associated with material deliveries also are presented in .... Tables 4.2-6 and 4.2-7. The scenario used to calculate daily and hourly emissions includes: 20 minutes for unloading and maneuvering at the site; 20 minutes of emissions while the truck approaches the unloading area at 32 kilometers per hour; and 20 minutes while the truck is moving away from the unloading area. As presented in Table 4.2-6, truck transport would result in more emissions than train transport even though trucks transport only 30 percent of total materials. Potential fugitive dust emissions associated with transportation are not included in this table.

\subsubsection{Workers' Vehicles}

Approximately 3,000 workers are anticipated for GRS construction between Months 9 through 11 of the construction schedule. Emission factors for workers' vehicles are presented in Table 4.2-8.

Maximum daily and hourly emissions associated with workers' vehicles are presented in Table 4.2-9. Roughly 1,800 of these workers were assumed to reside in onsite temporary housing and hence would not drive to work. It. $:$ should be noted that vehicles are mobile sources of emissions, and the emissions shown in Table 4.2-9 would be dispersed throughout a wide area (a radius of about 300 kilometers from the GRS site).

\subsubsection{Power Generation}

GRS construction is estimated to have a maximum onsite electricity demand of $10 \mathrm{MW}$. Electricity requirements could be met by connecting the site to the existing power delivery network, or by use of onsite power generators. Although the latter may be less likely, it would result in higher levels of emissions at the GRS site. Therefore, in order to be conservative, the use of onsite generators are considered for the purpose of developing a maximum potential emission scenario. It is assumed that turbines would be used to generate power. Again, in order to be conservative in calculating the potential emissions, it is assumed that the turbines would use diesel fuel. Emission factors and maximum daily and hourly emissions for the required electric power generation are presented in Tables 4.2-10 and 4.2-11. An additional 6 MW would be demanded by the inmigrating construction-related population. It is assumed that power requirements for this population would be provided by the existing electrical grid system. Emissions associated with generating this power requirement would be distributed throughout the regional electrical grid system and are not included in Table 4.2-12, which presents a summary of maximum daily and hourly emissions associated with GRS construction.

\subsubsection{IMPACTS ON AMBIENT AIR QUALITY}

Increases in ambient pollutant concentrations of hydrocarbons, nitrogen oxides, sulfur oxides, carbon monoxide, and total suspended particulates resulting from the clearing and grading activities and support structure manufacturing and installation operations have been estimated using the Environmental Protection Agency's PTMTP Gaussian plume model. Pollutant sources modeled Include trucks and trains used for transporting materials, 
Table 4.2-8. LIGHT-DUTY: VEHICLE EMISSIONS FACTORS

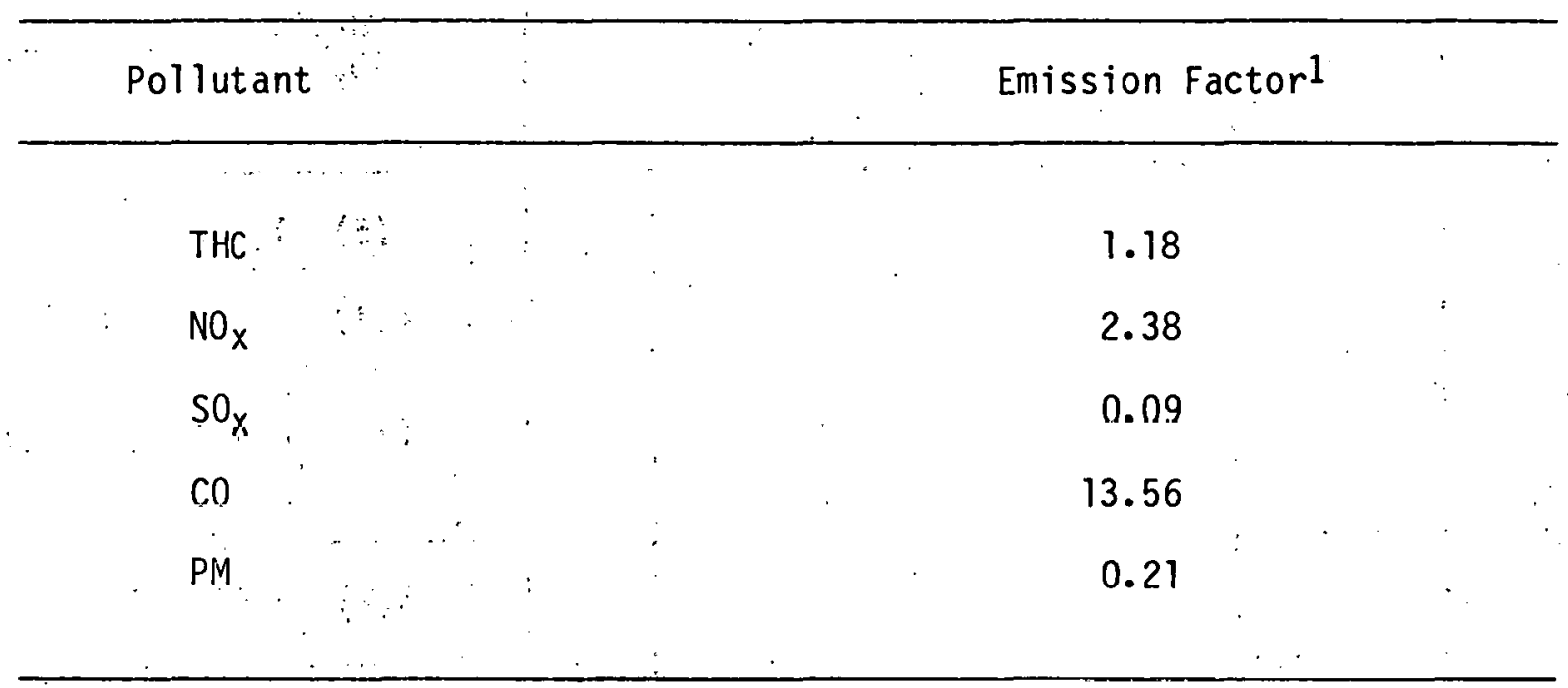

Source: U.S. EPA, "Mobile Source Emission Factors," Office of Air and Waste Management, Final Document EPA400/9-78-005, Washington, D.C., March 1978.

1. Assumes an average speed of $80 \mathrm{kilometers/hour.}$ 

Table 4.2-9. MAXIMUM DAILY AND HOURLY EMISSIONS ASSOCIATED WITH WORKERS'
VEHICLES 1

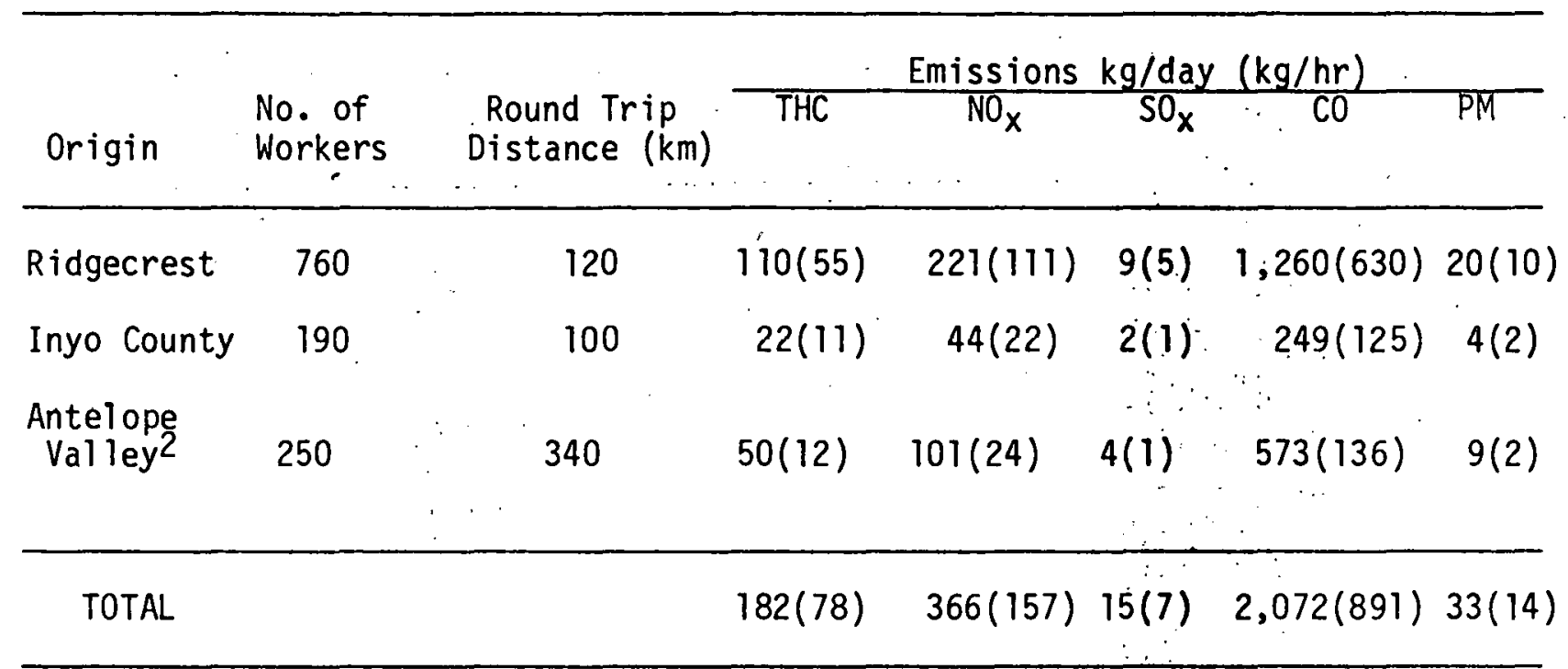

1. Based on emission factors preented in Table 4.2-8.

2. Assumes 2 workers per vehicle, a total of 125 vehicles per day. 
Table 4.2-10. POWER GENERATION EMISSION FACTORS

\begin{tabular}{lc}
\hline Pollutant & Emission Factor $(\mathrm{kg} / \mathrm{hr}$ rated load $)$ \\
\hline THC & 0.36 \\
$\mathrm{NO}_{\mathrm{X}}$ & 4.01 \\
$\mathrm{SO}_{\mathrm{X}}$ & 0.15 \\
$\mathrm{CO}$ & 0.99 \\
$\mathrm{PM}$ & 0.24 \\
\hline
\end{tabular}

Source: U.S. EPA, "Compilation of Air Pollutant Emission Factors," AP-42, Third Edition, Table 3.3:1-2, 1978. 
Table 4.2-11: MAXIMUM DAILY AND HOURLY EMISSIONS ASSOCIATED WITH CONSTRUCTION POWER GENERATION

\begin{tabular}{|c|c|c|c|c|c|c|c|c|}
\hline \multirow[b]{2}{*}{ Activity } & \multirow{2}{*}{$\begin{array}{l}\text { Rated } \\
\text { Load } \\
\text { (MW) }\end{array}$} & \multirow[b]{2}{*}{$\begin{array}{l}\text { Fuel } \\
\text { Type }\end{array}$} & \multirow[b]{2}{*}{$\begin{array}{l}\text { Engine } \\
\text { Type }\end{array}$} & \multicolumn{2}{|c|}{ Emissions 2} & \multicolumn{3}{|c|}{$\mathrm{kg} /$ day $(\mathrm{kg} / \mathrm{hr})^{3}$} \\
\hline & & & & THC & ${ }^{N O} x$ & $\mathrm{SO}_{\mathrm{x}}$ & $\mathrm{CO}$ & PM \\
\hline $\begin{array}{l}\text { Power } \\
\text { Generation }\end{array}$ & 10 & Diesel & Turbine & $86(4)$ & $962(40)$ & $36(2)$ & $238(10)$ & $58(2)$ \\
\hline
\end{tabular}

1. See Chapter 2 for power requirements.

2. Based on emission factors presented in Table 4.2-10.

3. Assumes continuous diesel turbine operation. 
Table $4.2-12$. SUMNARY OF MAXIMUM DAILY AND HOURLY EMISSIONS ASSOCIATEJ WITH GRS CONSTRUCTION (Months $9-11$ )

\begin{tabular}{|c|c|c|c|c|c|}
\hline & & Emissions & $\mathrm{kg} /$ day $(\mathrm{kg} / \mathrm{hr})$ & & \\
\hline Source & THC & $\mathrm{NO} \mathrm{X}_{\mathrm{X}}$ & $\mathrm{SO}_{\mathrm{x}}$ & $\mathrm{CO}$ & PM \\
\hline Rectenna Site $\mathrm{Cl}$ earing and Grading & $1.300(163)$ & $23,480(2,935)$ & $1,60 J(201)$ & $4,307(538)$ & $79,365(9,921)$ \\
\hline $\begin{array}{l}\text { Support Structure Manufacture } \\
\text { and Installation }\end{array}$ & $1,389(\approx 32)$ & $20,039(3,338)$ & $1,26 \overline{5}(210)$ & $3,961(661)$ & $2,527(338)$ \\
\hline $\begin{array}{l}\text { Delivery of Construction } \\
\text { Material }\end{array}$ & $238(c 2)$ & $2,923(176)$ & $260(25)$ & $616(48)$ & $136(12)$ \\
\hline Power Generation & $86(4)$ & $962(40)$ & $36(2)$ & $238(10)$ & $58(2)$ \\
\hline Workers' Vehicles & $182(78)$ & $366(157)$ & $15(7)$ & $2,072(891)$ & $33(14)$ \\
\hline TOTAL & $3,195(499)$ & $47,770(6,646)$ & $3,17 ?(445)$ & $11,194(2,11)$ & $82,119(10,287)$ \\
\hline
\end{tabular}


earthmoving equipment such as bulldozers, graders and dumptrucks, and construction machinery such as jackhammers and rock drills.

The modeling effort is intended to develop general conclusions on the pollutants that may cause problems and the relative magnitudes of the concentrations that may occur. Due to the many simplifying assumptions made (described bel ow in Section 4.2.3.1) and limitations within the model itself, exact values of resulting concentrations were not sought. The concentrations predicted are expected to be conservative because many mobile sources were treated as stationary sources, thereby overestimating the impacts from emitted pollutants, and because the Gaussian plume used in the PTMTP model is known to overestimate impacts.

\subsubsection{Modeling Approach}

The PTMTP computer model is capable of calculating hourly concentrations at up to 30 receptor points of pollutants emitted from up to 25 sources. A Gaussian Plume model is used. Required input data include the number, location and height of all sources and receptors, stack parameters of all sources, and hourly meteorological data on wind direction, wind speed, stability, mixing height and ambient air temperature.

A number of simplifying assumptions were made in developing the modeling inputs discussed above. Many of the sources modeled would be mobile sources. Because of model limitations, however, they were treated as stationary sources. The emissions occurring from grading and installation operations were assumed to occur evenly over the rectenna site. Due to the model's limitation of 25 sources, only one quadrant of the site was modeled. The total emissions assumed to occur within the quadrant (one-quarter of the total estimated emissions) were divided into 25 sources based on activities occurring. These 25 sources were distributed evenly in the quadrant and were assumed to emit pollutants steadily during the hour considered. (Fugitive dust emissions were not modeled.) Also, average values for stack parameters were assumed and applied to each source, rather than obtaining parameters for each individual source.

Eighteen receptor sites were chosen. The locations were chosen to lie on a line corresponding to the assumed wind direction beginning one kilometer north and west of the northwest corner of the quadrant and continuing to a puint 20 kilometers south and 20 kilometers east.

Only one hour of emissions were modeled. It is assumed that emissions occurring during this hour considered would be at their maximum level. Therefore, impacts on larger averaging periods would be less than those predicted for one hour. To obtain general estimations for other averaging periods it was assumed that each source would operate continuously for 8 hours during the day. Therefore, the three hour concentrations would be the same as the one hour concentrations, the 12 hour concentrations would be two-thirds the one hour value, and the 24 hour concentrations would be one-third of the one hour increment.

\subsubsection{Modeling Results}

The maximum one hour concentration increment predicted for hydrocarbons would be 243 micrograms/cubic meter $\left(u y / m^{3}\right)$. There is no callfornia state standard 
for hydrocarbons; rather their impact is measured in terms of the formation of oxidant. Depending on various factors such as insolation, reactivity of the hydrocarbons emitted, and possible quenching by nitrogen oxides, there may be a potential for oxidant formation in the area. The federal 3-hour standard for non-methane hydrocarbons is $160 \mathrm{ug} / \mathrm{m}^{3}$. This is exceeded by the total hydrocarbon concentration predicted. However, to determine if a problem would exist, the reactivities of the emissions would have to be determined. Table 4.2-13 presents a summary of the expected hydrocarbon concentration increase and the applicable standards.

The maximum concentration increment predicted for nitrogen oxides is 4,365 $\mathrm{ug} / \mathrm{m}^{3}$. While it is unlikely that GRS construction would actually yield such high ambient $\mathrm{NO}_{\mathrm{x}}$ levels, this datum does indicate that GRS-related $\mathrm{N} \mathrm{O}_{\mathrm{X}}$ levels are likely. to exceed ambient air quality standards unless mitigated effectively. Table 4.2-13 summarizes the nitrogen oxides concentration increase and the California one-hour standard.

A maximum one hour concentration increment of $267 \mathrm{ug} / \mathrm{m}^{3}$ is predicted for sulfur oxides. This value is well below the lalifornia one hour standard of $1,310 \mathrm{ug} / \mathrm{m}^{3}$. The federal secondary 3 -hour standard is $1,300 \mathrm{ug} / \mathrm{m}^{3}$. These would not be exceeded by the estimated 3 hour concentration increment of 267 $\mathrm{ug} / \mathrm{m}^{3}$. The california standard for 24 hours of $131 \mathrm{ug} / \mathrm{m}^{3}$ would not would be exceeded by the expected concentration increase of $89 \mathrm{ug} / \mathrm{m}^{3}$. However, if the existing ambient concentration of $\mathrm{SO}_{\mathrm{x}}$ is high, there may be a problem with complying with the state 24-hour standard and mitigation measures may be required. Table 4.2-12 summarizes the increases in sulfur oxides concentrations and the applicable air quality standards.

Carbon monoxide levels would increase a maximum of $774 \mathrm{ug} / \mathrm{m}^{3}$ according to the PTMTP model. This value is well below all California and federal standards. Table 4.2-13 summarizes the expected concentration increases and applicable standards. As shown in the table, an order of magnitude exists between the standards and the predicted concentration increases.

A one-hour increase of $155 \mathrm{ug} / \mathrm{m}^{3}$ in particulate matter is predicted to occur. There are no state or federal one-hour standards for particulates; however, standards do exist for a 24-hour averaging period. The expected 24hour increase in particulate concentration is $52 \mathrm{ug} / \mathrm{m}^{3}$. This added to the maximum 24 hour ambient concentration (obtained in 1977 at China Lake) of $110 \mathrm{ug} / \mathrm{m}^{3}$ would result in a net ambient concentration of $162 \mathrm{ug} / \mathrm{m}^{3}$. Which would exceed both the California Air Quality Standard of $100 \mathrm{ug} / \mathrm{m}^{3}$ and the Federal Secondary Air Quality Standard of $150 \mathrm{ug} / \mathrm{m}^{3}$. The Federal Primary Standard of $260 \mathrm{ug} / \mathrm{m}^{3}$ would not be exceeded. A summary of the applicable Cal ifornia and Federal standards and the expected concentration increases are presented in Table 4.2-12.

\subsubsection{CLIMATOLOGY}

The GRS does not appear to have the potential to cause significant climatological changes. In any event, such changes would not differ greatly in quality or quantity from those caused by urbanization. For example, the GRS would reject about $750 \mathrm{MW}$ over an area of roughly $100 \mathrm{~km}^{2}$, this is less than the amount typically rejected by comparably sized urban areas. 750 MW waste heat is commonly produced by 300-400 MW power plants, while large coal and nuclear installations may reject 2,000-6,000 MW. Clearly, in terms of waste heat, the GRS is far less "polluting" than many common practices. 
Table 4.2-13. AIR. QUALITY IMPACTS OF GRS CONSTRUCTION

\begin{tabular}{|c|c|c|c|c|c|c|c|}
\hline Pollutant & $\begin{array}{l}\text { Averaging } \\
\text { Period }\end{array}$ & $\begin{array}{c}\text { Concentration } \\
\text { Increment } \\
\left(\mathrm{ug} / \mathrm{m}^{3}\right)\end{array}$ & $\begin{array}{c}\text { Maximum Background } \\
\text { Concentration } \\
\left(\mathrm{ug} / \mathrm{m}^{3}\right)\end{array}$ & $\begin{array}{l}\text { Net Ambient } \\
\text { Concentration } \\
\left(\mathrm{ug} / \mathrm{m}^{3}\right)\end{array}$ & $\begin{array}{c}\text { California } \\
\text { AAQS } \\
\left(u g / m^{3}\right)\end{array}$ & $\begin{array}{c}\text { Federal } \\
\text { Primary } \\
\text { AAQS } \\
\left(u g / \mathrm{m}^{3}\right)\end{array}$ & $\begin{array}{c}\text { Federal } \\
\text { Secondary } \\
\text { AAQS } \\
\left(\mathrm{ug} / \mathrm{m}^{3}\right)\end{array}$ \\
\hline Hydrocarbons & 3-hour & 243 & $N / A$ & 243 & -- & 160 & 160 \\
\hline $\begin{array}{l}\text { Nitrogen } \\
\text { Dioxide }\end{array}$ & 1-hour & $4,3 \in 5$ & $N / A$ & 4,365 & 470 & -- & -- \\
\hline $\begin{array}{l}\text { Sulfur } \\
\text { Dioxide }\end{array}$ & $\begin{array}{l}\text { 1-hour } \\
\text { 3-hour } \\
\text { 24-hour }\end{array}$ & $\begin{array}{r}267 \\
267 \\
89\end{array}$ & $\begin{array}{l}N / A \\
N / A \\
N / A\end{array}$ & $\begin{array}{r}267 \\
267 \\
89\end{array}$ & $\begin{array}{r}1,310 \\
131\end{array}$ & $\begin{array}{r}-- \\
365\end{array}$ & 1,300 \\
\hline $\begin{array}{l}\text { Carbon } \\
\text { Monoxide }\end{array}$ & $\begin{array}{l}\text { 1-hour } \\
\text { 8-hour } \\
\text { 12-hour }\end{array}$ & $\begin{array}{l}774 \\
774 \\
516\end{array}$ & $\begin{array}{r}N / A \\
N / A \\
N / A\end{array}$ & $\begin{array}{l}774 \\
774 \\
516\end{array}$ & $\begin{array}{r}46,000 \\
-- \\
11,000\end{array}$ & $\begin{array}{r}40,000 \\
10,000 \\
--\end{array}$ & 10,000 \\
\hline $\begin{array}{l}\text { Particulate } \\
\text { Matter }\end{array}$ & $\begin{array}{l}\text { 1-hour } \\
24 \text {-hour }\end{array}$ & $\begin{array}{r}155 \\
52\end{array}$ & $\begin{array}{l}N / A \\
110\end{array}$ & $\begin{array}{l}155 \\
162\end{array}$ & 100 & 260 & 150 \\
\hline
\end{tabular}


The GRS will also alter the albedo and surface aerodynamics at the site. However, the atmospheric pertubations associated with the GRS are small in comparison with those attributable to urban areas in general, and will have a smaller impact.

It is conceivable that microclimatic changes may occur beneath the rectenna panels. Where a number of factors act simultaneously. First, the soil beneath the panels will experience an altered precipitation pattern due to the shading of the panels. Second, the panels will diminish the insolation and, therefore, the amount of surface heating. The panels also may diminish nocturnal radiative cooling. Finally, the rejected waste heat will serve to warm the areas beneath the panels to a modest extent. It is noteworthy that the loss of insolation is a few times greater than the amount of rejected waste heat, but only a thorough study of this problem can ascertain a precise estimate of the changes and impacts. However, such microclimatic changes would effect the character of the floral and faunal communities which are likely to reestablish themselves beneath the rectenna panels.

\subsubsection{MITIGATIUN}

The air pollution impact analysis reveals that $H C, N O_{x}$, and PM emissions during GRS construction may violate ambient air quality standards. CO emissions are clearly not a problem, and it is very unlikely that $\mathrm{SO}_{\mathrm{x}}$ emissions would cause violations of any standards.

The modeling could not include fugitive dust emissions. Hence, the PM concentrations presented in Table 4.2-13 do not include their effect. It is clear that if they were included severe violations of the PM standards would occur. PM standard violations could be greatly diminished and possibly avoided through the use of an effective dust suppression program during GRS construction and operation, and a protracted construction schedule. Such a program would probably consist of spraying water and dust suppressing agents over the construction site at regular intervals.

The modeled hydrocarbon concentrations are only slightly over the applicable standards and a protracted construction schedule.would prevent violations of the standards. In addition, more sophisticated and realistic modeling might reveal that $H C$ emissions are not a problem even with the existing construction schedule.

NOx emissions appear to be a problem. They arise solely from combustion of fuels in diesel engines, and at present there are no simple means to reduce or. control such emissions. However, a protracted construction schedule and the substitution of natural gas, propane or butane for diesel fuel wherever feasible would greatly reduce $\mathrm{NO}_{x}$ emissions and concentrations.

In summary, it appears that there are no air pollutant emissions, with the possible exception of $\mathrm{NO}_{x}$, which could not be fully mitigated through careful planning of GRS construction activities. The potential climatological impacts of the GRS can be minimized, if not fully alleviated, through careful selection of rectenna construction materials and geometry. 


\subsection{NOISE}

\subsubsection{ASSUMPTIONS, APPROACH AND NOISE -EMISSIONS}

Peak noise levels are expected to occur during GRS construction, primarily due to the heavy machinery used. The construction activities that would require the greatest amount of heavy equipment/machinery are rectenna field site preparation and support structure manufacture and installation. These activities occur during the Months 9-11 of GRS construction. There also would be a concrete plant, ten arch-making factories, and delivery of supplies by trains and trucks in the area close to the construction activities of concern. This area will be referred to as the centralized construction facilities zone.

As described in Chapter 2 (Description of the Proposed Project) rectenna field site preparation is expected to require the following equipment: 131 bulldozers, 176 road graders; 131 dump trucks, 89 cranes, and 45 backhoes. This equipment was assumed to operate eight hours a day. For the installation of footings for the support structures, 250 auger-jackhammers, 3 rock drills, 200 concrete pouring footing machines, and 90 concrete trucks would be required. Installation of the arches would require 63 trailertrucks, 60 manipulating cranes, and 3 concrete trucks. In addition, ten arch-making factories and a concrete plant would be operating in the centralized construction facilities area.

Table 4.3-1 lists typical noise levels associated with the equipment/operations that would be needed for rectenna field site preparation and support structure manufacture and installation.

While large numbers of heavy-duty equipment would be required for rectenna field site preparation and support structure manufacture and installation, not al 1 equipment would be operating at the same location. The rectenna field is large - 13.4 kilometers in length and $10.0 \mathrm{kilometers} \mathrm{in} \mathrm{width.}$ Construction activities would occur at various locations within the site. For purposes of this noise analysis, it was assumed that 10 percent of the equipment needed for rectenna field site preparation and support structure installation would be working in the western section of the site near the centralized construction facilities area. This area is expected to have the highest noise levels due to construction activities and operation of the concrete plant and arch-making factories. In addition, the main access road and rail spur tracts would be located in this area.

While the noise levels associated with the various pieces of equipment have been estimated (Table 4.3-1.), a total of the noise levels produced by multiple pieces of machinery in the area of concern cannot be approximated simply by addition of all noise levels associated with the various equipment/operations. Noise levels, expressed as A-weighted decibels (dBA), are logarithmic units and as such are not linearly additive. To estimate the total noise level produced by multiple sources, several of the activities/equipment generating the highest noise levels were added according to the following equation:

where

$$
I L=10 \log \left[\sum_{i=1}^{m} n_{i} 10^{\left(I L_{i} / 10\right)}\right]
$$


Table 4.3-1. TYPICAL NOISE LEVELS ASSOCIATED WITH CONSTRUCTION EQUIPMENT/ OPERATIONS NECESSARY FOR RECTENNA FIELD SITE PREPARATION AND SUPPORT STRUCTURE MANUFACTURE AND INSTALLATION

A. Rectenna Field Site Preparation:

Equipment

Bulldozer 1

Road Graders 2

Dump Trucks 2

Cranes 2

Bdckliues?
Noise Level at 15 Meters

$(\mathrm{dBA})$

$$
\begin{array}{r}
87 \\
80-94 \\
82-93 \\
76-87 \\
77-9 ?
\end{array}
$$

B. Support Structure Manufacture and Installation:

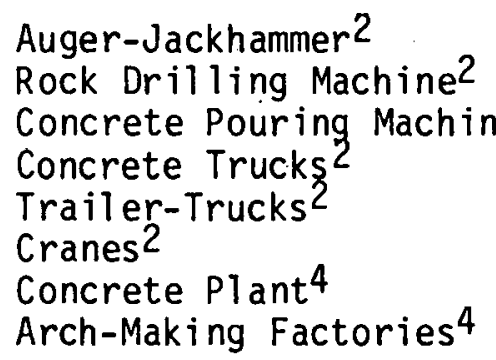

$82-98$

$82-98$

$82-85$

$82-93$

$82-93$

$76-87$

69

69

1. Source: Federal Register 39:121 (June 21, 1974).

2. Source: U.S. Environmental Protection Agency (EPA), "Noise from Construction Equipment and Operations," EPA Report PB-206-717 (1971).

3. Noise levels shown to approximate concrete pouring machines are those for concrete pumps.

4. Noise levels shown to approximate the concrete plant and arch-making factories are those for outside the turbine building of a power plant. 


$\begin{array}{ll}\mathrm{IL} & =\text { total sound intensity level (dBA) } \\ \mathrm{m} & =\text { the number of different noise sources } \\ n_{i} & =\text { the number of the } i^{\text {th }} \text { type of noise sources } \\ I_{i} & =\text { intensity of the } i^{\text {th }} \text { noise source (dBA) }\end{array}$

It should be noted that this approach overestimates the actual noise levels since it implicitly assumes that all of the noise emanates from a single point. While much of the equipment with lower noise levels has not been considered, the total noise level produced by various activities/equipment is largely a function of the highest noise levels if the difference between low and high noise levels is not small (see Figure 4.3-1). Figure 4.3-1 indicates that if two noise levels differ by six decibels, then there would only be a contribution of one decibel to the higher noise level. Hence, by considering only those activities or pieces of equipment with high noise levels, whose difference in levels is not significant, and which can reasonably be in the same location (and thus treated as one source), the total noise level produced by more than one noise source can be estimated.

The noise analysis will be divided into two estimates according to location. The first location considered would be the construction site closest to the centralized construction facilities area. The construction activities occurring would be rectenna field site preparation and support structure installation. The second location in which noise levels will be estimated is the centralized construction facilities area. Specific sources/activities entering into noise level estimations in the centralized construction facilities area are trains, trucks, and operation of the concrete plant and arch-making factories.

There would be a large number of construction workers and thus a large number of vehicles transporting the personnel. However, since the maximum noise level was sought, noise from workers' vehicles was not estimated because operation of the vehicles and of construction equipment/machinery are largely exclusive events, and personal vehicle noise levels are lower than those of construction equipment.

The equipment which would generate the highest noise levels in rectenna field site preparation and support structure installation would be the augerjackhammers and rock drills. Noise levels associated with this equipment range from 82 to $98 \mathrm{dBA}$ (Table 4.3-1). For purposes of the noise analysis, the high noise level of $98 \mathrm{dBA}$ was chosen. It was assumed that a maximum of nine auger-jackhammers and one rock drill could reasonably operate in close proximity and thus be treated as one noise source. The total noise level generated by nine auger-jackhammers and one rock drill, as determined by the sound intensity equation presented previously, would be $108 \mathrm{dBA}$ at 15 meters.

Noise levels associated with trucks, cranes, and operation of the concrete plant and arch-making factories at the centralized construction facilities site are presented in Table 4.3-1. It was assumed that three trucks, one train, the concrete plant, and ten arch-making factories would have the largest contributions to noise levels in the centralized construction facilities area. As determined by the sound intensity equation, the total noise level generated by the sources of concern would be $90 \mathrm{dBA}$ at 15 meters. 


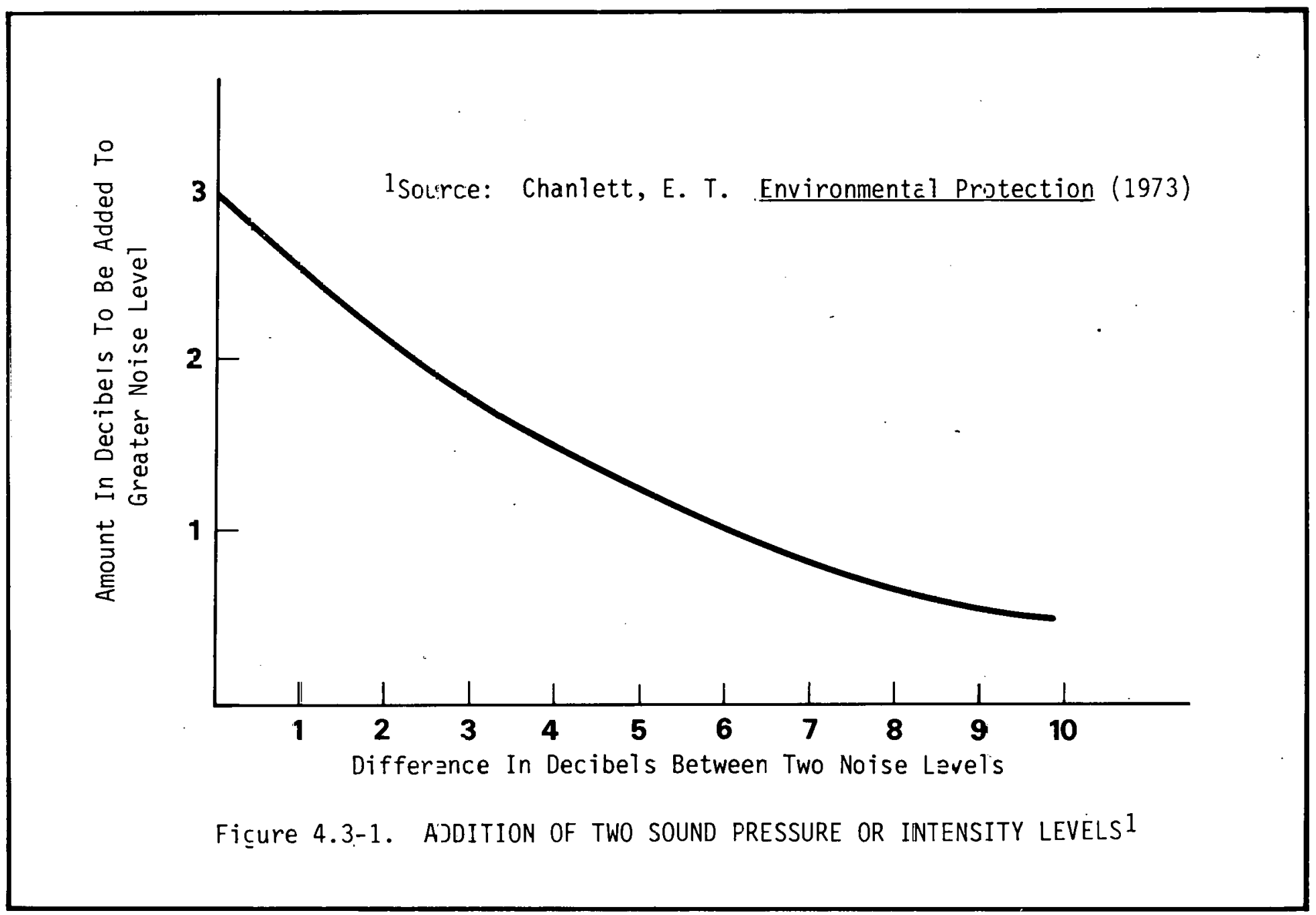




\subsubsection{EXPECTED NOISE LEVELS OF GRS DEVELOPMENT}

The effect of the noise generated by construction activities upon residents in the rectenna field vicinity is, potentially, a major area of concern. As described in Chapter 3, the study area is largely an undeveloped region with few human noise receptors in the area. A few ranchers live along U.S. Highway 395 and there is a small settlement at Little Lake. There are workers at the mines, ranches, and at the China Lake Naval Weapons Center but seldom does anyone stay overnight except at the hotel or ranches. The decrease in noise levels over distance must be considered when determining the potential effects of noise upon human receptors. The noise impacts of GRS operations are expected to be insignificant.

Sound levels are inversely related to the distance from the noise source. The noise level decreases by $6 \mathrm{dBA}$ for each doubling of distance from the source to the receiver (Hodges, 1973). This reduction in noise levels with distance is based on the absence of hills or vegetation, both of which have noise-insulating properties resulting in further decreases in noise levels.

Table 4.3-2 indicates that at a point less than two kilometers from the area of rectenna field site preparation, noise levels would decrease by $42 \mathrm{dBA}$ (from $108 \mathrm{dBA}$ to $66 \mathrm{dBA}$ ). An area two kilometers from the rectenna field preparation site is well within the rectenna field area or the buffer zone on the western side. Residents closest to the construction area live in Coso Junction, more than $2.5 \mathrm{kilometers}$ away. Noise levels at Coso Junction would decrease by $48 \mathrm{dBA}$ at that point, resulting in a noise level of $60 \mathrm{dBA}$. To put these noise levels into perspective, refer to Table 4.3-3. On a human response basis, $64 \mathrm{dBA}$ is not considered "loud." It should al so be noted that there would be a further decrease in interior noise levels due to the noise-insulating properties of the dwelling.

Noise generated by the activities considered in the centralized construction facilities area would also decrease by $42 \mathrm{dBA}$ at a point two kilometers from the sources - from $89 \mathrm{dBA}$ to $47 \mathrm{dBA}$ (refer to Table 4.3-2). A noise level of $47 \mathrm{dBA}$ is considered "quiet" - equivalent to a private business office or a living room in a home (Hodges, 1973). Human receptors closest to the GRS site live more than two kilometers from the centralized construction facilities area.

During the night noise levels would be somewhat lower than those discussed above, since not all construction activities are planned on a 24-hour basis, but an assessment of nighttime noise impacts is not possible until the nature and scope of such construction activities are determined. However, on the basis of the worst-case noise estimates determined above, it appears very unlikely that GRS construction would have significant noise-related impacts on either humans or animals which were a modest distance (circa $2 \mathrm{~km}$ ) from the site of GRS construction activities.

In summary, it is expected that noise levels from rectenna field preparation or from the centralized construction facilities area would not adversely affect residents in the study area. Those residents nearest the major noise sources are sufficiently removed to result in a large decrease in noise levels over the distance from the rectenna field preparation and centralized construction facilities area to the residents' homes. In addition, noise attenuating properties of the dwellings would cause a further decrease in lhe nuise levels perceived by residerits. 
Table 4.3-2. DECREASE IN NOISE LEVELS WITH DISTANCE FROM THE, SOURCE

\begin{tabular}{lcc}
\hline & \multicolumn{2}{c}{ Noise Level (dBA) } \\
\cline { 2 - 3 } $\begin{array}{c}\text { Distance from Source } \\
\text { Kilometers (feet) }\end{array}$ & $\begin{array}{c}\text { Rectenna Field } \\
\text { Preparation }\end{array}$ & $\begin{array}{c}\text { Centralized } \\
\text { Construction } \\
\text { Facilities Area }\end{array}$ \\
\hline $0.015(50)$ & 108 & 89 \\
$0.030(100)$ & 102 & 83 \\
$0.061(200)$ & 96 & 77 \\
$0.122(400)$ & 90 & 71 \\
$0.244(800)$ & 84 & 65 \\
$0.488(1,600)$ & 78 & 59 \\
$0.975(3,200)$ & 72 & 53 \\
$1.951(6,400)$ & 66 & 47 \\
\hline
\end{tabular}


Table 4.3-3. TYPICAL SOUND LEVELS OF VARIOUS NOISES

$\begin{array}{lccc}\text { Noise } & & & \\ \text { Level } & \text { Quality of } & \text { Community (or } & \text { Home (or } \\ (\mathrm{dBA}) & \text { Sound } & \text { Industrial2 } & \text { Outdoors) }\end{array}$

200

170

Near the muzzle

of an automatic

weapon (170)

$\begin{array}{ll}170 & \begin{array}{l}\text { Can begin to } \\ \text { feel pain }\end{array} \\ 120 & \begin{array}{l}\text { Uncomfortably } \\ \text { loud }\end{array}\end{array}$

Medium jet

engine (170)

$\begin{array}{ll}110 & \\ 100 \quad \text { Very loud } \\ 90 & \begin{array}{l}\text { Moderately } \\ \text { loud }\end{array}\end{array}$

Riveting machine (110) Textile loom

(106)

Electric furnace area (100)

Rock band

$(108-114)$

Jet flyover,

from $1,000 \mathrm{ft}$.

(103)

Power mower (96) Inside subway car, at $35 \mathrm{mph}$ (95) $\begin{array}{lll}\text { Cockpit, pro- } & \text { Motorcycles, } & \text { Food blender } \\ \text { peller aircraft } & \text { from } 25 \mathrm{ft}(90) & (88)\end{array}$ (88) Cotton spinning (83)

Diesel truck, 40 Garbage disposal mph from $50 \mathrm{ft}$ (84)

(80

Clothes washer

(78)

Diesel train, 40-50 mph, from $100 \mathrm{ft}(83)$ Living room music (76)

70 Passenger car, Dishwasher (75) $65 \mathrm{mph}$ at distance of $25 \mathrm{ft}$ (77)

60 Near freeway auto traffic (64) (60) Air conditioning Private office unit, at distance (50)

TV audio (70) of $20 \mathrm{ft}(60)$ Light traffic at

50 Quiet distance of 100 ft (50)

40

30 Very quiet

20

10 . Just audible

Rustle of

leaves (10)

Quiet residential neighborhood (40)

Whisper (20)

Threshold of hearing

1. Source: George Moriber, Environmental Science, 1974.

2. Values in parentheses represent decibels. 
The effect of noise levels upon construction workers in the area also should be considered. While the methodology previously used est imated noise levels of $108 \mathrm{dBA}$ from rectenna field preparation and $89 \mathrm{dBA}$ from activities in the centralized construction facilities area, this technique was developed to characterize the maximize the effect of multiple noise sources upon residents as represented by a single noise level. This methodology is an approximation and is not entirely appropriate when considering the effect of noise levels on construction workers. Instead, the noise levels generated by individual sources should be considered since these values are more accurate representations of actual noise levels and since-workers would likely be subject to an individual noise source (e.g., a piece of equipment/machinery, truck, train, etc.).

Table 4.3-4 indicates noise level standards for occupational settings. When comparing noise levels generated by the equipment/activities presented in Table 4.3..4 to occupational noise standards, it is apparent lhat some of the occupational standards would be exceeded.

\subsubsection{MITIGATION}

No measures are necessary to mitigate the effects on local residents of noise levels generated by construction activities upon residents in the area. The distance between the rectenna field area and the residents is sufficiently large to result in a significant decrease in the noise levels perceived by the residents.

Measures may be necessary to mitigate possible adverse effects of noise levels from equipment/act ivities upon construction workers. Several mitigation measures available would include mufflers wherever feasible on machinery/ equipment, special insulation encompassing noisy operations in the concrete plant and arch-manufacturing factories, and ear protection devices worn by t.he wrirkers.

rurther, mitigation should be considered to protect wildiife species in the area (see Section 4.7 ). This could involve avoidance of particularly noise-sensitive habitat areas in siting various support facilities, access roads, etc., although such flexibility is not possible for elements of the rectenna itself once the rectenna field is sited. Scheduling construction activities to minimize disruption of sensitive habitats during critical times of the year (e.g. breeding and nesting seasons) also should be considered.

\subsection{GEOLOGY/SOILS}

This section discusses the potential geologic/soils impacts of GRS construction and operation, and geologic/soils constraints which the Rose Valley/Coso area places on the GRS. The emphasis is largely on constraints, since the potential for direct geologic and soils impacts associated with the GRS appears to be relatively small. The topics which are covered include seismic hazards, weak and expansive soils, and erosion and flonding. 
Table 4.3-4. PERMISSIBLE NOISE EXPOSURES IN OCCUPATIONAL SETTINGS 1

\begin{tabular}{cc}
\hline $\begin{array}{c}\text { Duration } \\
\text { (hours/day) }\end{array}$ & $\begin{array}{c}\text { Sound Level } \\
(\mathrm{dBA})\end{array}$ \\
8 & 90 \\
6 & 92 \\
4 & 95 \\
3 & 97 \\
2 & 100 \\
$11 / 2$ & 102 \\
1 & 105 \\
$1 / 2$ & 110 \\
$1 / 4$ or less & 115 \\
\hline
\end{tabular}

1. Source: Federal Register, 34(96) (May 20, 1969). 


\subsubsection{GEOLOGIC IMPACTS AND CONSTRAINTS}

\subsubsection{Introduction}

The potential geologic impacts of GRS siting and construction are limited to (1) subsidence, (2) landslides, and (3) earthquakes. However, it is very unlikely that GRS-related activities could trigger any of these phenomena. Subsidence is generally caused by excessive surface loads or the withdrawal of underground fluids. The surface loads associated with GRS activities. are not sufficient to cause subsidence. However, subsidence could result from groundwater withdrawal if the GRS and other local water consumers were to severely lower the Rose Valley/Coso water table. In addition to its hydrologic and water quality impacts (see Section 4.5), such subsidence could alter the rectenna's attitude with respect to the satellite and thereby reduce its efficiency, possibly causing rf interference.

Earthquakes have been triggered by surface loading, injection of fluids and underground nuclear testing. The GRS poses ony one of these potential triggers (i.e., surface loading). However, surface load-triggered earthquakes have been associated only with very large reservoirs, and it is exceeding unlikely that the GRS could cause even a microearthquake, even in an area as seismically active as Rose Valley/Coso.

Surface loads can cause landslides. However, two factors would prevent the GRS from triggering such events. First, it is a distributed rather than concentrated load. Second, it is located in a relatively flat area which is not prone to sliding, and it is not located at the head of slopes which have the potential to slide.

In view of the above discussion it appears that the potential geologic impacts of GRS siting at Rose Valley/Coso are limited to constraints on GRS construction and operation due to geologic hazards. These hazards could include seismic shaking, surface faulting, ground failure, landsliding, weak soils, erosion and flooding. Impacts from these constraints would be structure- and sitespecific.

\subsubsection{Sejsmic Hazards}

Earthquake associated damage can result from surface-fault rupture, strong ground shaking, ground failure induced by earthquake shaking (landsliding, settlement, liquefaction) or any combination of these effects. The great majority of earthquake damage is caused by strong ground shaking, and geologic hazards in the study area will largely be those associated with earthquake shaking.

The Rose Valley/Coso study area is located in a seismically active region (see Figure 3.5-1). There are several major active fault zones with in 100 kilometers. (Active faults are those that show evidence of ground displacement within Holocene time, approximately the last 11,000 years. Such faults are considered capable of generating future earthquakes and surface displacement.) The GRS could experience significant ground shaking from a major earthquake on any of the local or regional fault zones. 


\subsection{Ground Shaking}

The extent of earthquake damage to man-made structures depends on many variables: earthquake magnitude, focal distance and depth, duration and intensity of shaking, subsurface soil conditions and response characteristics, and structural design.

Unless a structure is astride an active fault and can thus be directly affected by fault displacement, proximity to an act ive fault is usually less important than ground response in determining earthquake damage. Historic seismicity and active fault location and extent are important data for evaluating the duration, frequency and intensity of ground motion and the potential for ground failure. Some general relations are outlined below.

An earthquake frequency vs. magnitude relationship, or recurrence curve, depicts the level of observed historic seismicity in an area. It can provide an estimate of the probability of future earthquake activity if the historic record is detailed enough and covers a sufficiently long time span. This is a probablistic approach and provides no assurance that earthquakes on any fault system might not actually be larger or occur more frequently than the recurrence curve indicates.

Figure 4.4-1 is a recurrence curve for earthquakes of magnitude 3 or larger recorded in the southern Sierra Nevada from 1932 to 1971. This curve is based on a relatively short instrumental record and is therefore subject to considerable uncertainty. The curve indicates, for example, that a magnitude 6 earthquake has a probability of occurring once every 333 years per 1,000 square kilometers, or about once every 40 years for the entire southern Sierra region defined in the Hileman, et al , study (1973).

Relationships between maximum acceleration in rock, magnitude of earthquake and the distance of the site from the causative fault (i.e. zone of energy release) have been summarized by Seed, et al., (1969). Schnabel and Seed (1972) have estimated maximum rock accelerations using data from the San Fernando, California earthquake of 1971 and new analytical techniques.' It must be emphasized that a considerable degree of judgment should be exercised in applying these estimates to any particular site, especially if the site is not on bedrock (and Rose Valley/Coso is not). Local soil conditions, topography and the structure's characteristics have a great influence on damage potential at a site. Actual bedrock and soil accelerations would have to be derived at the individual site.

For a rough estimate of maximum bedrock acceleration several possible maximum credible earthquakes may be considered for Rose Valley/Coso. (The maximum credible earthquake is defined as the severest earthquake believed to be possible at the site on the basis of geological and seismological evidence.) Likely candidates would include a magnitude 8-1/4 earthquake on the Owens Valley fault zone, or possibly on the Sierra Nevada fault zone. The minimum distances from the GRS center to the nearest mapped traces of these faults is about $30 \mathrm{~km}$ and $10 \mathrm{~km}$, respectively. Based on the relations developed by Schnabel and Seed (1972), the average values of maximum acceleration in bedrock produced by these candidate maximum credible earthquakes would be about $0.35 \mathrm{~g}$ and $0.55 \mathrm{~g}$, respectively. Accelerations at the ground surface in Rose Valley would be lower due to attenuating effects of soill. These 


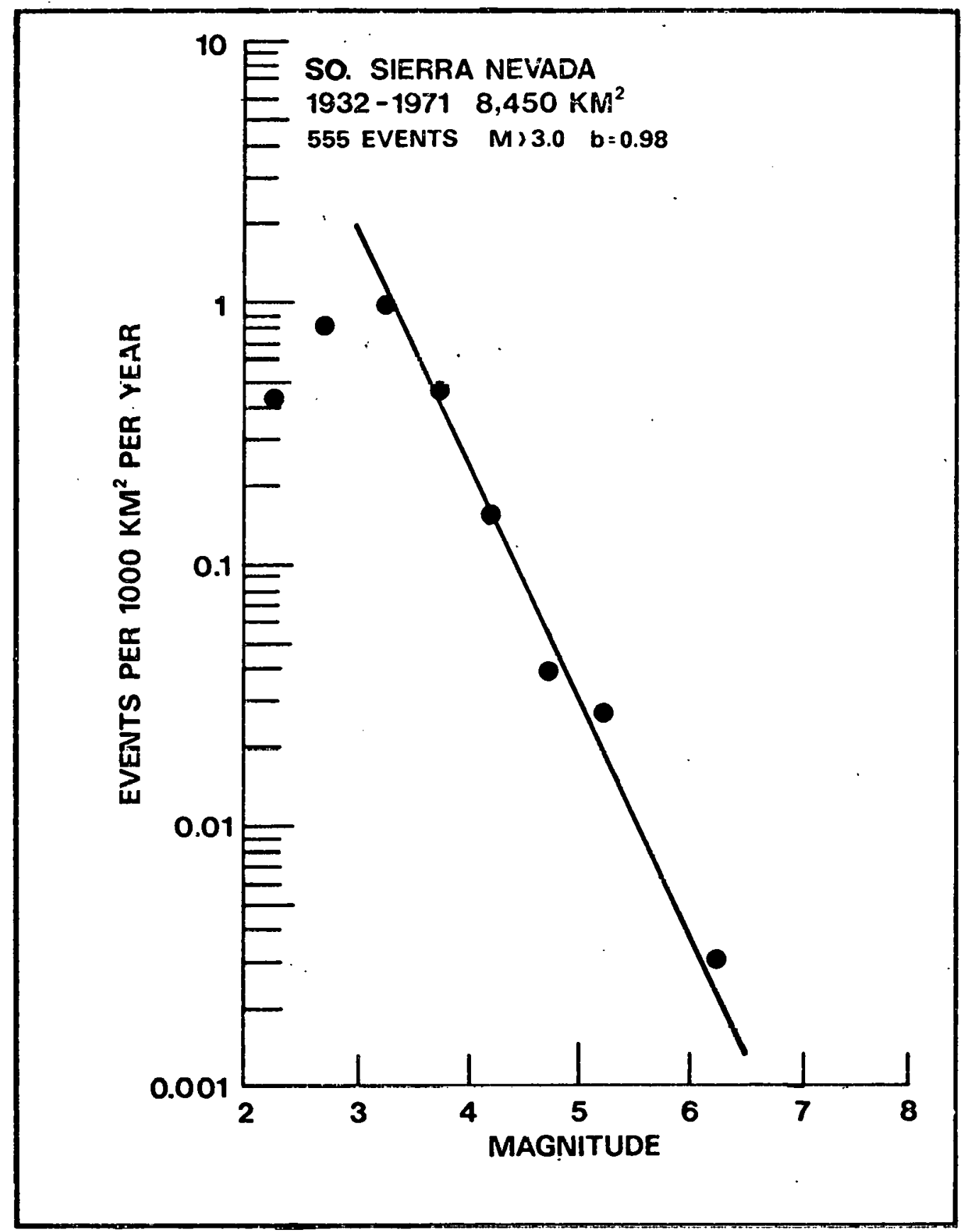

Figure 4.4-1. RECURRENCE CURVE FOR EARTHQUAKES IN THE SOUTHERN SIERRA NEVADA REGION 
accelerations are typical of those encountered in southern California and should not pose problems which cannot be alleviated by proper engineering design and construction.

The Seismic Zone Map of the United States (Uniform Building Code, 1979), shows Rose Valley/Coso in Seismic Zone 4. This includes those areas that lie within a zone of major (magnitude greater than 7) historic earthquakes and high levels of recent seismicity. It denotes that major damage corresponding to intensities VIII or higher on the Modified Mercalli Intensity Scale can be expected in the study area vicinity.

Only a detailed engineering and geologic analysis could assess the implications of seismic events on the GRS. It seems unlikely that ground shaking would cause the rectenna to collapse, but it is possible that it might alter the attitude of many of the panels and reduce the rectenna's efficiency; and the reflected radiation might cause rf interference.

\subsection{Surface Faulting}

The Sierra Nevada fault zone is adjacent to Rose Valley/Coso. The Little Lake fault zone is a smaller, act ive adjacent zone located in southernmost Rose Valley. Several faults mapped by St. Amand and Roquemore (1978) and Duffield and Bacon (7977) within Rose Valley/Coso are apparently act ive. In addition, some of the Rose Valley/Coso traces appear to line up with the Owens Valley fault zone to the north.

While there is always some possibility of future faulting in any locality in a seismically active region, the historical occurrence of surface faulting has generally closely followed the trace of existing active faults. Therefore, surface faulting or rupture is most likely to occur on traces of active faults.

Estimation of the type, amount and frequency of displacement on the faults within Rose Valley/Coso requires stydies as specified in the mitigation section. Assuming that the surface traces in Rose Valley/Coso might be an extension of the Owens Valley fault zone, an order of magnitude approximation of potential surface displacement may be based on the following observations:

- Displacement on the Owens Valley fault is complex, with a combination of roughly equal components of normal and right-lateral strike slip movement during the 1872 earthquake ( $\mathrm{Hill}, 1972$ ).

- Maximum horizontal displacement on the Owens Valley fault during the 1872 earthquake was 5.5 meters $(\mathrm{Hill}, 1972)$.

If the faults in Rose Valley are part of this system, then displacement from a maximum credible event would be on the order of six meters horizontal.and vertical. The pattern of displacement would be irregular, with components of shear deformation and block tilting.

Surface faulting could destroy the GRS. This could arise from the total destruction of the rectenna and its associated buildings, or the rectenna's attitude could be so altered as to render it useless. 


\subsection{Other Ground Failure Induced by Shaking}

Settlement or densification may occur in sandy soils above the groundwater table or in earth filled areas during earthquake loading due to rearrangement of particles. A potential for earthquake induced settlement exists in the al luvial areas of Rose Valley.

Liquefaction occurs only in cohensionless soils where the water table is near the surface. (Liquefaction - the sudden large decrease of the shearing resistance of a cohesionless soil caused by the collapse of the structure by shock or strain, and associated with a sudden temporary increase of pore pressure fluid. It involves temporary transformation of the material into a fluid mass.) It is not likely in most parts of Rose Valley/Coso because of the deep groundwater table. However, the groundwater levels in the southernmost portion of the Rose Valley are shallower and would have to be defined in more detail to evaluate this risk.

Settlement and liquefaction could alter the rectenna's attitude, decreasing its efficiency and possibly causing rf interference. This problem is exacerbated by the tact that the rectenna site includes several soil types and thereby has a potential for differential settling.

\subsubsection{Lands liding}

Landslides may be initiated by response to strong earthquake shaking and/or improper grading. Motion on both active and ancient landslides may occur during earthquakes. Most areas of Rose Valley are relatively level, and should not be subject to landslide problems.

\subsubsection{SOILS IMPACTS AND CONSTRAINTS}

\subsubsection{Introduction}

The total disturbance of over 10,500 hectares must be viewed as a significant impact on soil resources. The soils of Rose Valley/Coso are also quite variable and could pose several limitations on GRS construction. (Soil characteristics are summarized in Section 3.6.). A summary of the sensi- . tivities, capabilities and constraints imposed by Rose Valley/Coso soils includes the following (a soils map is presented as Figure 3.6-1):

- Wind and water erosion of soils is a significant impact which would occur as a result of removal of vegetative cover and topsoil disturbàncè.

- Soils of the playa bottoms are subject to compaction when wet. Since the Rosc Vallcy/Coso GRS site includes several playas, there is a large potential for such compaction.

- Garlock and Garlock variant soils (Soil Unit 5 in Figure 3.6-1) on old terraces and basalt flows have high shrink/swell potential. Those parts of the rectenna constructed on such soils will have to be designed to compensate for this effect.

- Coso and Haiwee soils (Soil Unit 6 in Figure 3.6-1) are rocky soils developed on granitic rock and impose difficult conditions for construction. 
- Alko, Nebona and Nebona variant soils (Soil Units 3 and 4 in Figure 3.6-1) are bouldery, shallow to hardpan, and pose difficult construction conditions. Once disturbed, these areas would be difficult to revegetate.

- Areas mapped as Riverwash and Arizo soils (Soil Units 2 and 3 in Figure 3.6-1) may be subject to periodic flash flooding. The rectenna must either be designed to withstand such floods, or be protected by a system of culverts and drains.

\subsubsection{GRS Construction Impacts}

Surface vehicular access to all areas of the rectenna site will be required. This will include equipment for grading, cut and fill, footing excavation, etc. Impacts to soil resources from such activities will include both direct physical displacement of soils and soil compaction. The degree of localized damage to soil is a function of soil properties including particle size distribution, organic content, slope and moisture content. Tire ruts or displaced soil on slopes have the potential to divert surface runoff, and may cause accelerated soil erosion. The sandy Coso soils (Soil Map Unit 6) on sloping terrain present the most serious potential soil erosion impact. Scars may persist for long periods of time after the soil disturbance.

Soil compaction as a result of off-road vehicular travel may occur when the surface is wet or moist due to recent precipitation or snowfall. The finer textured soils of the playas and adjacent areas are the most susceptible to soil compaction. A secondary impact caused by soil compaction is the effect on revegetation of affected areas. Soil compaction disturbs the natural a topsoil and subsoil and impedes the recolonization of native plants. The significance and magnitude of these potential impacts is a function of the amount of disturbance, and hence GRS construction is likely to result in severe soil disturbance.

A third impact on soil resources may result from footing excavation material left on the soil surface. This is estimated to be somewhat less than one cubic meter of material per footing, or a total of about 3.7 million cubic meters. Since excavated material is usually low in fertility and does not support vegetation, it represents visual scars and may induce accelerated wind and water erosion. In addition, the existing topsoil, which may have value in revegetation efforts, will be disturbed as a result of construction activities. There will also be impacts from spills of gasoline and lubricating materials, litter from the crew, parking of personal vehicles and other associated activities.

\subsubsection{GRS Operation Impacts}

As a result of surface disturbance, there will be an associated loss of natural soil productivity which is expected to occur throughout the life of the project. The soil resources within Rose Valley/Coso are presently used for rangeland and wildlife habitat. However, due to sandy surface textures, dryness, steep slopes, presence of a hardpan, stoniness and the hazard of soil blowing, the soils are considered to be poorly suited for use as rangeland. Loss of rangeland is considered to be insignficant when viewed within a regional context; however, the loss may be apparent for many years after 
the project life because soils in a desert environment do not revegetate quickly. Loss of wildlife habitat is an indirect impact related to surface disturbance of soils (see Section 4.7).

During periods of heavy rainfall, sheet erosion can displace large amounts of soil. Soil protection on slopes by vegetation (or revegetation), riprap, or chemical treatment would lessen this effect. Heavy precipitation also causes flooding of enclosed basins forming playas. Some adverse increases in soil erosion and sedimentation are likely to occur due to soil disturbances associated with GRS construction and operation until soil stabilization has been achieved. (See Section 4.5 for a more complete discussion of erosion and sedimentation.)

\subsubsection{Soils Constraints}

Geologic hazards can result from weak, compressible or expansive soils or erusiurl problens. Enylneering soll investigations would have to be pertormed at specific prospective building sites to determine soil conditions for site development and foundation design.

Surface soils in arid, desert climates may weather by frost heaving. It occurs in cold months when wet ground freezes and thaws diurnally. This expansive freezing has a weakening effect on soils.

Each Soil Unit shown on the general soils map (Figure 3.6-1) represents many subunits, each with its own characteristic physical properties. Even within each subunit properties vary areally and with depth. Within these limitations, engineering interpretations and suitability of soil groups for specific

applications are outlined in a Technical Appendix to the Coso Geothermal DES (U.S. Department of the Interior, Bureau of Land Management, 1980). The characteristics delineated in this study are:

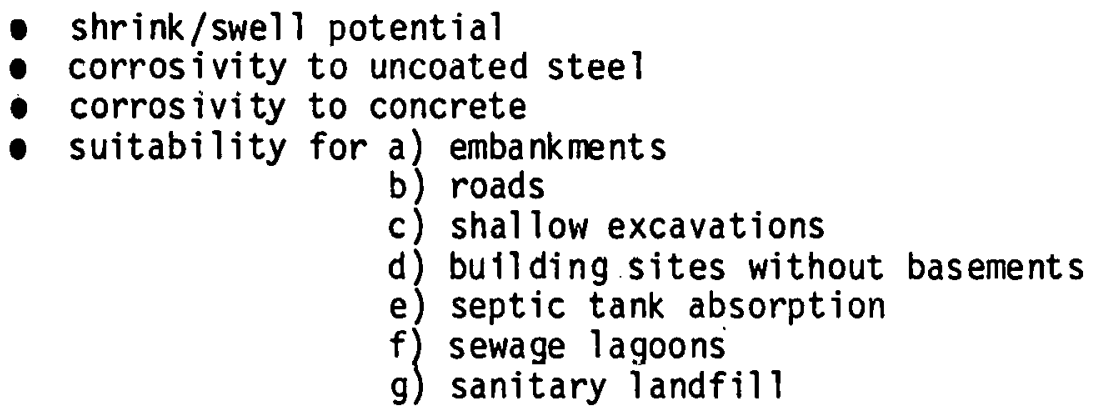

Some spectfic remarks about the soils found at Rose Valley/Coso, based on the Coso Geothermal ES technical appendices, will clarify the variety and types of constraints the soils impose on GRS construction. The major soils found on the floor of Rose Valley are Units 1 to 6 (see Figure 3.6-1). The Dunmovin soils (Unit 1) have a moderate to high potential for corrosivity to uncoated steel. The Lavic and Wasco Variant soils (Unit 2) have a low to moderate shrink/swall potential which must be considered when designing panel footings. In addition, they range from slightly to highly corrosive to uncoated steel. The Sparkhule, Garlock Variant and Gass Variant soils (Unit 5) have a moderate to high shrink/swell potential and are moderately to highly corrosive to uncoated steel. The Dunmovin (Unit 1) and Coso (Unit 6) soils are noncohesive 
sandy soils which have a low bearing strength and nearly uniform particle size distribution that renders them poorly suited for certain types of engineering applications.

The Rose Valley/Coso soil characteristics outlined above demonstrate that the rectenna will have to be designed to meet a variety of constraints imposed by the soils. Specifically, the rectenna must be designed to withstand the corrosivity of the soils, their widely varying shrink/swell potentials, lack of cohesiveness in some areas, and variable excavation difficulty.

\subsubsection{GEOLOGY/SOILS MITIGATION}

As discussed in the section above, GRS construction and operation will have some geologic/soils-related impacts. In addition, soils and geology place a number of constraints upon the GRS. This section suggests measures to both mitigate the impact of the GRS on the geologic/soils setting, and means to relieve some of the constraints imposed on the GRS by the soils and geology of Rose Valley/Coso.

To minimize the potential geologic hazards discussed previously, site- and structure-specific studies should be completed prior to construction. These would include:

- Determination of the effects of potential ground shaking to permit optimum earthquake resistant design. For critical structures, this would include estimates of the duration, magnitude and frequency of potential ground motions. These data would be considered with the predominant period and other structural characteristics in design of the proposed structures.

- Detailed fault mapping to avoid inadvertently locating facilities astride active faults, and to determine the relation of local faults in Rose Valley with the larger regional structures. This should include studies to determine the precise location, age, amount and frequency of fault displacements.

- Landslide mapping to avoid inappropriate grading or development on or near landslide areas.

- Foundation studies to determine soil conditions and strength beneath the proposed structures for each soil type within the rectenna site."

- Consideration of a maximally light and open rectenna panel design to allow sunlight and precipitation to reach the ground, and reduce wind resistance and inertia. For example, trusses rather than arches might be used to support the panel centers. This would require fewer. footings and less materials. It would also increase shear strength and earthquake damage resistance.

In order to minimize the soils impacts of GRS construction, vehicles and equipment should be subject to the following mitigation measures:

- Vehicle travel should be restricted when soil surfaces are wet or moist in order to reduce soil compaction and the potential for generating ruts and wheel höles. 
- Vehicle speed should be minimized to reduce dust generation.

- Carefully planned, accepted, construction practices, based on documents such as Section 9110 and 9111 of the Bureau of Land Management Manual and Standard Specifications for Construction of Roads and Bridges on Federal Highway Projects (U.S. DOT, FP74) should be used as guidelines for all construction activities. These documents specify criteria and guidelines for grading, cuts and fills, compaction, drains and runoff control, erosion control; and other construction activities.

- Topsoil resources having value for revegetation efforts should be stripped, stockpiled and stabilized at suitable sites prior to and during all earthwork activities.

- Alkali-resistant concrete should be used.

- The rectenna shnuld be designed bearing in mind the diversity of soil types likely to be encountered at the GRS site.

- Provisions should be made to protect the rectenna from flashfloods.

- Certain types of coatings and/or paints may be desirable to protect the panels and structures from abrasion during dust storms, and from the alkalinity of the soils.

A carefully planned program of soil stabilization will have to be developed to prevent excessive soil erosion and sedimentation. This could take the form of paving parts (or all) of the rectenna field site, the use of dustsuppressing chemicals; or revegetation of the site. However, each of these mitigation measures has potential environmental implications. For example, paving the site would control fugitive dust emissions, soil erosion and sedimentation, but large quantities of runoff would require disposal and floral and faunal habitats would be totally destroyed. Revegetation would require large amounts of water, which is difficult to obtain in arid regions. The use of dust suppressants might cause water pollution downstream during periods of heavy rainfall and runoff.

\subsection{HYDROLOGY/WATER QUALITY}

4.5.1, INTRODUCTION

This section evaluates the impacts of GRS construction and operation on the hydrology and water quality of the Rose Valley/Coso area. The GRS has the potential for significant impacts on water resources, but as discussed below, these impacts can be mitigated.

The potential hydrologic impacts of GRS construction and operation can be divided into three categories: water consumption, degradation of natural water quality, and drainage modification. For each of these categories, GRS hydrologic impacts may be divided into two phases. The first is the construction phase, which would involve the most extensive and exhaustive surface disturbance. The second is GRS operations, which would involve water use 
for domestic purposes, and possibly dust suppression or irrigation (for revegetation), and modification of surface drainage over a very large area for the life of the GRS structures.

If GRS construction were to utilize local groundwater resources at Rose Valley/Coso, it potentially could lower the water table in Rose Valley. Disposal of liquid waste and interruption of surface drainage patterns might degrade natural water quality. The following discussion of hydrologic impacts is based on analysis, interpretation and extrapolation of limited available data developed for the Coso Geothermal Lease Program DES (U.S. Department of the Interior, Bureau of Land Management, 1980).

\subsubsection{WATER CONSUMPTION AND AVAILABILITY}

There will be three main water requirements during GRS construction: concrete production, dust suppression and labor force-related consumption. These requi rements are listed in Table 4.5-1.

It is more difficult to estimate the water requirements for GRS operation. During operations, water will be required for labor force related consumption ( 500 thousand $\mathrm{m}^{3} /$ year), dust suppression and/or irrigation (for revegetation purposes).

As discussed in Section 4.4, the operating GRS will have to employ a soil stabilization program. This could involve a revegetation program which could require about 27 million $\mathrm{m}^{3} /$ year for irrigation during the first three years; thereafter, natural precipitation would provide sufficient moisture..

The use of dust suppressants is an alternative stabilization method. This would require about 15,000 to 22 million $\mathrm{m}^{3}$ per year, depending upon the chemical(s) used, and assuming five applications per year,throughout the life of the project. Hence, GRS operations will require a minimum of 500,000 $\mathrm{m}^{3}$ per year plus the water required for soil stabilization.

Water use in Rose Valley is presently estimated at four million $\mathrm{m}^{3}$ per year: with the great majority being used for irrigation at Rose Valley Ranch. Water use is projected to increase to about $5.6 \mathrm{million}^{3}$ per year in 2000 , with over 90 percent of this use being for irrigation.

No surface water is available for use in the Rose Valley/Coso area. Hence, GRS water requirements would have to be met either by pumping local groundwater or by importing water from outside the immediate area. This section addresses the impacts of meeting project needs from local groundwater; other than $\because$, pointing out that the City of Los Angeles aqueduct system runs through Rose : Valley and that the California State Water Project aqueduct brings water to . southern California from the northern part of the state, the issues relating to obtaining imported water for GRS use are not addressed.

Groundwater recharge in Rose Valley is estimated at 4.3 to 5.7 million $\mathrm{m}^{3} /$ year (as outlined in Section 3.7). This roughly balances the present estimated discharge of 4.7 to $5.6 \mathrm{milli}$ ion $\mathrm{m}^{3} /$ year; hence, the Rose Valley groundwater basin presently appears to be near hydrologic equilibrium. Unless further study indicates greater recharge, this suggests that additional significant groundwater withdrawal would lower the water table in Rose Valley. 
Table 4.5-1. ANNUAL WATER CONSUMPTION DURING GRS CONSTRUCTION1

\begin{tabular}{lc}
\hline \multicolumn{1}{c}{ Activity } & $\begin{array}{c}\text { Estimated Quantity } \\
\text { 000 Cubic meters }\end{array}$ \\
\hline Concrete Product.ion & 910 \\
Dust Suppression & $75-11,000^{3}$ \\
Labor Force and Domestic Use & 850 \\
\hline TOTAL & $1,800-13,000$ \\
\hline
\end{tabular}

1. Source: See Appendix A.

2. One acre-foot $=1,233$ cubic meters.

3. Wide range depends on type of chemical used for dust suppression. 
Water availability from lowering the water table would average about 2.6 to 3.9 million $\mathrm{m}^{3}$ per foot of drawdown for the upper 300 meters of sediments. The total volume of water in storage is estimated to be 4.1 to 6.2 billion $\mathrm{m}^{3}$ of this total, 1.7 to 2.5 billion $\mathrm{m}^{3}$ are within 300 meters of the surface. Most of the water in storage is believed to be usable, although geothermal reservoir fluid in the Coso Mountains to the east of Rose Valley may extend into the alluvial materials on the east side of the valley, and saline water may occur in other locations.

It should be noted that there are legal constraints to pumping groundwater in the southwestern deserts, as in other areas. The nature of these implications are variable. In some groundwater reservoirs, pumping permits are not being issued; in others, permits are being issued with limitations, or for preferred uses only, or are subject to priorities of existing water uses.

To assess the environmental effects of proposed water use on the hydrologic regime, the estimated GRS water use was compared with the available water in the Rose Valley groundwater basin. Assuming groundwater recharge and discharge presently balance at about $4.9 \mathrm{million} \mathrm{m}^{3} /$ year, the Rose Valley groundwater basin would be overdrafted by 1.9 to 12.3 million $\mathrm{m}^{3} /$ year for the two years of GRS construction. This overdraft would draw down the water table 0.2 to 1.5 meters per year.

During operations, taking the year 2000 as an example, the basin would be overdrafted by 1.2 to $3.3 \mathrm{million} \mathrm{m}^{3} /$ year, assuming 0.6 to 2.7 million $\mathrm{m}^{3}$ per year for GRS operations. This would result in a water table drawdown of 0.1 to 0.4 meters per year.

Considering only the effects of the GRS facility, and assuming two-year construction and a 30-year project life, the total water use would be 41 to $120 \mathrm{million} \mathrm{m}^{3}$, assuming no irrigation for revegetation. This use would result in an average water table drawdown in Rose Valley of about 3 to 15 meters. Total drawdown in the basin, considering all other water uses would be greater.

Lowering the water table in Rose. Valley:

- would reduce the quantity of groundwater in storage;

- might reduce the quantity of underflow into Indian Wells Valley to the south;

- might lower the water level in Little Lake;

- might affect surface vegetation;

- might degrade natural water.

Reducing the amount of groundwater in storage impact would decrease the amount of water available for future uses from Rose Valley. Indian Wells Valley would be affected by a reduction in the hydraulic gradient between Rose Valley and Indian Wells Valley. However, the quantity of such underflow, perhaps several thousand $\mathrm{m}^{3}$ per year, may be insignificant in relation to 
the water balance in Indian Wells Valley. Drawdown of Little Lake would occur since Little Lake is fed by groundwater from natural springs, and is in hydraulic communication with the Rose Valley aquifer. Vegetative impacts would affect only natural phreatophytic vegetation, which is virtually nonexistent in Rose Valley. Degradation of natural water quality is discussed below.

\subsubsection{DEGRADATION OF NATURAL WATER QUALITY}

There are three main mechanisms by which GRS construction and operation might degrade water quality at Rose Valley/Coso: (1) groundwater drawdown, (2) sewage disposal, and (3) increased sedimentation. The potential impact of each of these mechanisms is discussed below.

GRS-related groundwater use in conjunction with other Rose Valley/Coso groundwater consumption could affect water quality through the contamination of usable supplies by nonusable water. (Nonusable water refers to water of too poor quality to suit its intended use; it is generally characterized by high salt, boron, fluoride and tracc metals content.) This type of pollution would occur if groundwater withdrawal caused the flow of nonusable water into the Rose Valley/Coso aquifer. The magnitude of such impacts would depend upon the following factors:

- The degree of subsurface hydraulic communication among reservoirs of usable and nonusable water.

- The precise location of and extent of nonusable water; which is not clearly defined throughout Rose Valley.

- The hydraulic relationships between the known geothermal reservoirs and the adjacent groundwater reservoir in Rose Valley, which is not well understood.

- The locations and rates of groundwater extraction in Rose Valley.

There are not sufficient data available to permit a precise estimate of either the magnitude or probability of such impacts. "However, it is known that nonusable water and geothermal reservoirs exist at Rose Valley/Coso, and that these reservoirs contain fluids which would surely contaminate the Rose Valley's potable groundwater if thcy were allowed to enter the aquifer. It is also known that these reservoirs have some (albeit unknown) degree of hydraulic communication with the Rose Valley groundwater system. It is clear that GRS groundwater use would have to be carefully planned and monitored to provide adequate protection for Rose Valley water quality.

The main source of 1 iquid waste from GRS construction would be sewage from the project workforce, including the onsite temporary housing. This would result in a total flow of 3.4 million liters per day of raw sewage. Other potential sources of liquid waste problems include concrete production and arch fabrication, aggregate washing, surface runoff (which could include dust suppression agents), and the disposal and leakage of ojls and greases from vehicles and machines.

Precipitation in the Rose Valley/Coso area is so low that there is no recharge to the groundwater from the valley floor. Hence, any potential contaminants 
which are dissolved in water flowing over the surface will percolate a maximum of one meter into the soil. This water would then evaporate, leaving the precipitated solids in the soil profile. When any degraded material is carried by surface runoff, the remnants would be left in the playas where the water evaporates. The only place where percolation could reach the water table is in the extreme southern part of the valley, near Little Lake, where the water table approaches the surface. However, this is an extremely limited area and could be protected.

A septic system leach field to handíe the amount of sewage associated with GRS construction would be very large, and perhaps unmanageable. In addition, it would contaminate a large amount of soil. However, the groundwater table is very deep in most parts of Rose Valley, particularly the northwestern portions, and groundwater would not likely be contaminated. Sewage treatment provides a second means of sewage disposal, which is probably more appropriate for GRS construction. For éxample, a system where treated effluent is collected in a pond and then sprayed on a slight slope and evaporated might be used. In an arid environment, such as Rose Valley, with an evaporation rate of about 3.3 meters per year, a spraying area of less than 0.5 hectares would be required.

Increased sedimentation is the third mechanism by which the GRS might degrade natural water quality. All surface drainage in Rose Valley is ephemeral. Runoff that does not reach the valley floor collects in playas and quickly evaporates, which precludes water quality degradation. However, degradation through increased sediment load could be a problem at Little Lake which is downstream of Rose Valley, although this is unlikely except in the event of a large storm.

The potential adverse environmental effects of soil stabilization chemicals cannot be evaluated until a soil stabilization program has been defined. In the development of such a program the intensity of water use and the availability of water should be considered, as well as any potential adverse effects associated with the selected soil stabilization chemical(s). If revegetation is employed rather than chemical soil treatment, then due consideration must be given to the initial intensive water use, the potential fire hazard, and the effects of creating new, and to some extent "unnatural," biological habitiats.

\subsubsection{SURFACE RUNOFF}

Construction activities would result in extensive soil and vegetation disturbance and dust emissions. Such land surface disturbance will alter surface runoff patterns and increase soil erosion and sediment load. Development of an appropriate erosion control plan will be an important element in GRS preconstruction planning.

It is anticipated that runoff from the rectenna field site would not be significantly altered as a result of GRS construction. The sandy soils of the Rose Valley floor are largely cohesionless, and are not expected to have altered infiltation rates due to construction activities. Since infiltration in the playas is presently zero, runoff could not increase. Some of the cohesive soils are likely to have decreased infiltation due to compaction from construction vehicles, but this would be largely offset by the increased infiltration resulting from construction activities on rocky soils. 
The amount of increased sediment yield associated with the runoff will depend on the effectiveness of the soil stabilizing materials used. If inadequate drainage controls were implemented, increased sediment load would tend to accumulate in the southern portions of the rectenna field, which currently are ephemeral drainage-ways and playa areas. This could cause increased sedimentation and possible filling of Little Lake.

Flashfloods may occur in any dry wash in the Rose Valley/Coso area, particularly those which are steep and covered. with less permeable materials. These floods are common in arid environments with the heaviest storms occuring in summer. Facilities built in the paths of these floods could be damaged. Since the GRS would be constructed on the relatively flat alluvial floor, it would likely be out of the path of most of these floods.

\subsubsection{MITIGATION}

\subsubsection{Lowering of Rose Valley Water Table}

As stated previously, lowering the water table in Rose Valley would affect the few naturally occurring phreatophytes in the area, and perhaps lower the level of Little Lake. Further study would be required to determine which of the following kinds of mitigation measures would be most cost effective:

- Establishment of a water management plan to inciude potential importation of water as well as obtaining water from nearby sources.

- Limitation of non-GRS development to avoid impacts to Little Lake.

- Using water pumped from nearby wells to maintain the level of Little Lake.

The nearby alluvial valleys do not contain nearly as much water, or have as much recharge as Rose Valley. However, they might be able to supply some of the required water, thereby reducing the amount extracted from Rose Valley. For example, recharge into upper Coso Basin is estimated at 480,000 cubic meters per year. If most of this water could be captured, it could supply a few hundred thousand cubic meters per year for GRS activities. Groundwater extraction from upper Coso Basin would reduce underflow to Indian Wells valley, however (as would extraction from Rose Valley).

The water level in Little Lake could be maintained, as it has been in the past, by feeding the lake from wells north of the lake. Keeping this water level at present levels would likely also maintain underflow to Indian Wells Valley.

\subsubsection{Degradation of Natural Water Quality}

If the GRS were to utilize Rose Valley groundwater, baseline hydrologic conditions would have to be established for eastern Rose Valley and the Coso Mountains. This would include measurement of water levels and determination of water chemistry characteristics of groundwater reservoirs in these areas. Interference tests between wells and/or tracer studies would be required to. 
establish the degree of hydraulic communication among the geothermal reservoir, the Coso Mountains, and the groundwater reservoir in Rose Valley. A permanent ongoing water quality monitoring plan would be advisable in order to detect any possible induced flow from the geothermal and/or nonusable water reservoirs into Rose Valley.

A properly maintained sewage disposal system would be expected to preclude water contamination arising from liquid wastes. Increased sedimentation downstream of the GRS (i.e. Little Lake) does not appear to be a serious problem. A well-planned and managed soil stabilization program would ensure protection of the Little Lake area.

\subsubsection{Flood Hazard}

Flood hazards could be mitigated by prudent siting of GRS facilities and by proper engineering to protect the project from floods.

\subsection{FLORA}

The following section discusses direct and indirect impacts on plant communities of both GRS construction and operation. Overall impacts on plant communities in the Rose Valley/Coso area are addressed, as well as impacts on particularly sensitive floral areas and any rare or endangered species.

\subsubsection{GENERALIZED IMPACTS ON PLANT COMMUNITIES}

GRS siting will involve direct impacts on floral communities stemming from the disturbance of the land surface on the GRS site, as well as from the development of access roads, railroads, ancillary facilities, etc. There is also the potential for indirect impacts on plant species due to changes in hydrologic conditions (e.g. drawdown of the groundwater table), air and water pollutant emissions, as well as casual and recreational activities by project personnel.

The major direct impact will result from the allocation of 10,500 hectares of land for the rectenna field. Additional land disturbance which will affect plant communities include development of the main access road to the site, the required rail spur, temporary construction phase facilities (e.g. storage areas, construction personnel housing, shop areas), the electric power collection system, permanent ancillary facilities (e.g. control center and administrative facilities) and the perimeter fence and patrol road. These activities will disturb roughly 400 additional hectares of land surface area. The impacts on plant communities resulting from these various land allocations will differ between GRS construction and GRS operations.

\subsubsection{Construction Phase}

Rectenna field site preparation will involve the clearing and grubbing of the 10,500 hectares allocated for the rectenna field, and hence the removal of all vegetation from this land area. In Rose Valley, the northern two-thirds of the rectenna field-disturbed area would consist of plants primarily of the Creosotebush Scrub community, with Creosotebush and burro weed the dominant. species. The southern one-third of the rectenna field site-disturbed area. is primarily of the Shadscale Scrub association, with shadscale and associated 
bud sagebrush the dominant species. In addition, small areas where allscale and the Joshua Tree are important constituents of the vegetation also would be cleared. Because of the soil disturbance during site preparation and the subsequent rectenna construction activities, no significant naturally-occurring revegetation is expected during the GRS construction period.

Other GRS construction phase activities (e.g. development of support facilities, roads, rail spur) would disturb additional acreage; in the Rose Valley area, impacts would be largely to the common Creosotebush and Shadscale Scrub associations.

\subsubsection{Operations Phase}

In the absence of efforts to prevent it, some natural revegetation of the rectenna field site will occur during GRS operations. However, soil compaction due to vehicular and equipment use during construction might prevent or delay reestablishment of vegetative cover. In desert scrub communities, natural regeneration of disturbed areas is very slow - 30 to 40 years under the best of circumstances and otten IUU years or more. Revegetation, when it does occur is generally initiated with the appearance of short-lived pioneer species which can colonize areas of disturbed soil (Vasek et al. 1975). Succession then may occcur as these pioneer species are foTowed by longer-lived perennial species.

Regeneration of the naturally occurring vegetation at the GRS site will be affected by the following factors:

- Measures taken to control erosion (e.g. use of dust suppression chemicals or the encouragement of particular vegetative species to stabilize the soil).

- Continued disturbance/compaction of the soil caused by maintenance vehicular traffic between the rows of panels; and wind and water erosion leading to the exposure of plant roots, loss of nutrients, and abrasion or burial of downwind plants by windblown solid materials.

- Changes in the pattern of natural infiltration of precipitation on the site, which would depend in part on how surface runoff at GRS is managed, as well as on soil compaction and disturbance stemming from construction and operations phase activities.

- Displacement of naturally recurring plants by weedy and non-native species such as Russian thistle. If weeds were to be controlled with herbicide, annther notential impact on revegetation (and on the floral and faunal community as a whole) would require consideration.

- Microclimatic changes (e.g. temperature, humidity, wind, precipitation) under the rectenna panels caused by the radiation reflection and absorption characteristics of the rectenna panels and supports, the efficiency of power conversion and transmission in the rectenna field and possible effects of the rectenna structures on wind patterns and on the distribution of precipitation over the ground surface within the rectenna field. These types of microclimatic changes may serve 
to alter the potential for floral recolonization and succession. If the changes are significant, plant species adapted to more moderate conditions may have a greater chance for revegetation than plant species which are now common in the Rose Valley area.

- Possible leachates from rectenna structures (i.e. panels).

Revegetation can be expected along the rail spur right of way, as well as on the land areas disturbed by construction activities or temporary facilities which are not needed for permanent operations. Vegetation losses from land devoted to the main access road, the perimeter road and permanent ancillary facilities will be for the life of the project. It is expected that vegetation along the edges of GRS access roads would be somewhat enhanced by GRS development, increased water supplies from roadway runoff are thought likely to contribute to this enhancement (Vasek, et al., 1975b).

\subsubsection{Indirect Impacts - Construction and Operations}

Potential sources of indirect impacts on plant communities include air pollutant emissions, water quality or supply changes and activities of construction and operations personnel.

GRS construction vehicle and equipment use, as well as soil disturbance will increase local levels of nitrogen oxides and particulates. Both nitrogen oxides and high levels of particulates can adversely affect plant communities. In addition, construction equipment emissions may contribute to increased oxidant levels in the area; increased oxidant levels are toxic to plants (Moore and Moore, 1976). Operations phase air emissions are not expected to be of a magnitude that would have any significant impacts on plant communities.

Changes in water quality or quantity could significantly affect plant communities that depend on the affected water supplies. GRS impacts on these sensitive floral areas are discussed below in Section 4.6.2.

Casual and recreational use of the GRS vicinity by construction or operations personnel could impact plant species, particularly to the extent that off Road Vehicles (ORVs) are involved. ORV use can damage plant communities by direct injury to plants and indirectly by damage to soils (e.g. compaction, increased erosion potential.) As this impact can be considered directly proportional to the number of project personnel in the area, impact potential would be expected to be greatest during the GRS construction phase.

\subsubsection{IMPACTS ON SENSITIVE FLORAL AREAS AND RARE AND ENDANGERED SPECIES}

The plant communities around Little Lake and those associated with several small playas in southern Rose Valley (within the rectenna field site) constitute sensitive areas of special significance in terms of GRS impact potential because of their distinctive nature and their importance to wildlife.

A well developed riparian plant community exists at Little Lake, which includes desert cordgrass (Spartina gracilis), listed as rare and endangered by the California Native Plant Society. Reduction of water levels and impacts on water quality at Little Lake could change or eliminate the riparian vegetation there. Lower water levels due to groundwater drawdown could cause the reduction 
or loss of such emergent aquatic plant species as bullrush (Scirpus olneyi) or cattail (Typha sp.). Rush grasses as well as salt grass (Distichlis spicata) would become established on the former lake bottom (as it is exposed) and a marsh would eventually result. Further drawdown would cause even the marsh to dry up and the riparian community would then be severely reduced or eliminated. In addition, drawdown conceivably could cause influx of water from the geothermal system to the northeast, if, in fact these hydrologic areas are interconnected (which cannot be ruled out, although it is considered unlikely).

Potential changes in water quality which could affect the Little Lake plant community could be brought about by inadequate control of sewage and other liquid wastes (such as equipment oils) and increased erosion. Sewage and other 1 iquid wastes would cause a degradation of water quality in Little Lake. Deposition of windborne dust and sand into the lake as well as sediment transport by storm runoff would both lead to increased turbidity and would hasten the filling of the lakebed with sediment. Both sewage and increased sedimentation would hasten the ecological succession of Little Lake with aquatic and riparian vegetation encroaching, creating a swampland and eventually an alkali sink plant community. The small playas to the north and east of Red Hill and their associated vegetation would be completely eliminated by the construction of the rectenna. Since many annual plants occur within this area, an important habitat would therefore be lost.

In terms of rare and endangered species, Spartina gracilis (desert cordgrass) is classifed as "very rare and rare and endangered" (one category) by the California Native Plant Society. This plant, which occurs in only one locality in the study area (on the shore of Little Lake), would be threatened with el imination if the water supply to Little Lake were to be degraded in quality or if water levels were to change significantly. Spartina gracilis, however, is widely distributed through the western United States (Munz, 1974).

Canbya candida, the white canby poppy, which is designated as "rare and not endangered" by the CNPS, is found locally only near Red Hill, within the GRS rectenna site. This population would be eliminated hy rectenna field site preparation activities.

Several additional species of plants of limited distribution (but not on protected species lists), are found in the study area. GRS construction could eliminate significant fractions of the populations which may exist in the area because of the large size of the rectenna field.

\subsubsection{MITICATION}

\subsubsection{Construction Phase}

Once the precise location of the rectenna field is established, there will be nothing that can be done to avoid the total vegetation loss associated with rectenna field site clearing and grading. At the Rose Valley study site, all of the vegetat ive resources, including the extant population of the White Canby poppy, Canbya candida, which is designated as "rare and not endangered" by the California Native PTant Society, would be destroyed. There may be somewhat more flexibility in the sitng of access roads and various ancillary facilities, however. Thus, a primary, mitigating measure, which is avoidance of the impact, may be possible for some areas of unusual or rare plant associations. 
If natural revegetation after GRS construction is desired, floral recolonization efforts should be begun as soon as possible after the major ground disturbing construction are completed. Natural recolonization will depend on the seasonal and climatic conditions at the time of cessation of disturbance to the soil and on the seed source available (Vasek et al., 1975b). The natural germination of plants within the rectenna field after construction will depend on the viability of seeds in the soil following construction activity soil disturbance, and on natural seed dispersal (largely by wind) from the surrounding areas. Studies would be required to assess the adequacy of potential natural recolonization and to determine potential response to seasonal and climatic factors. If potential natural revegetation is considered to be sufficient for biological or other purposes (e.g. soil stabilization), efforts should be made to optimize the timing of construction activities in order to maximize positive effects of seasonal and climatic factors. Water application designed to stimulate germination and early growth of flora may be required to initiate adequate revegation. If natural reseeding and germination is insufficient, an artificial seeding or planting program may be required.

The Little Lake riparian community, which includes the rare desert cordgrass (Spartina gracilis), is sensitive to water quantity or quality changes (i.e. drawdown of groundwater table). This would require that water well levels in Rose Valley be carefully monitored during construction, as Little Lake is fed by groundwater. Also, to prevent water quality degradation, careful erosion and flood control measures would have to be incorporated into GRS construction plans and design. In addition, wastewater disposal at the construction site must be carefully planned to avoid water quality degradation from sewage or other liquid wastes.

ORV use in the vicinity by project construction personnel would have to be carefully controlled to prevent damage to floral communities. No special mitigation would be anticipated for GRS construction phase air quality emissions.

\subsubsection{Operations Phase}

As stated above, revegetation must be considered to mitigate the impacts of rectenna field grading and clearing. It should be noted that issues such as fire prevention and soil stabilization must be considered in defining the optimal vegetative resources mitigation program.

[cologically, the desired objective would be restoration of vegetative resources: as close to the pre-existing state as possible, i.e. using native plant species. However, fire prevention might militate toward planting particularily fire retardant plant species (which might not be native to the site area). Further, it may be advisable to use vegetation (or chemicals) to stabilize the soil and help control wind and water erosion. The vegetative species. that are optimal from this perspective also could be in conflict with the objective of revegetation with native species.

As: discussed in Section 4.6.1.2, natural revegetation of disturbed desert scrub areas is. a very slow process; it can take over 100 years for a disturbed area to fully recover. Some natural revegetation would occur inevitably; at the GRS.site, unless special measures were taken to prevent it, although the resulting floral communities might be quite different from their predecessors. However, a number of factors would affect natural revegetation. As identified in Section 4.6.1.2 these could include: measures taken to control wind erosion 
(e.g. use of dust suppression chemicals); continued soil disturbance/compaction in GRS maintenance operations; changes in natural infiltration for rainfall patterns, microclimatic changes under the rectenna panels; and encroachment by non-native and weedy plant species.

An active revegetation program is likely to be required, if revegetation is desired, for example, for soil stabilization purposes. This could require a soil rehabilitation effort and/or a seeding or planting program. Sizable amounts of water could be required; it is estimated that up to 40 centimeters per year (which far exceeds natural precipitation) could be required for the first three years. Some sort of irrigation system could be required to achieve this.

Operationally, rectenna maintenance programs and procedures would have to be planned so as to minimize vehicular damage to soils and revegetating flora. Monitoring of groundwater levels (to prevent degradation of sensitive riparian habitats fed from groundwater) would be advisable during operations; the status of any rare nr proter.ted plant. species in the site vicinity also should be monitored.

Introduction of non-native plant species, which conceivably could be required for soil stabilization or fire protection purposes, would adversely affect faunal recolonization of the rectenna field by native species. This is because desert fauna are rather narrowly adapted to specific natural floral conditions. Introduction of non-native plants al so could provide competition for native plant species in the immediate vicinity and/or introduce plant pests or diseases.

\subsection{FAUNA}

The following section discusses direct and indirect impacts on faunal communities of GRS construction and operation. Overall impacts on wildlife communities are addressed, as well as potential impacts on particularly sensitive habitat areas and rare or protected species.

\subsubsection{GENERAL IZED IMPACTS TO FAUNAL COMMUNITIES}

GRS siting. will involve direct impacts on faunal communities from the disturbance of the land surface on the GRS site as well as from associated developments such as access roads, railroads, etc. Indirect impacts also may occur due to hydrologic changes, air and water pollutant emissions, noise and other disturbance related to the presence of the project construction and operations work force.

The major direct impact to wildlife will stcm from the conversion of 10,500 hectares of land area from its current largely undeveloped state to use for the rectenna field. The clearing, grubbing and grading of this land area represents by far the largest land alteration associated with GRS development, and will represent a major impact on the existing faunal habitats of the disturbed area. The impacts of this land disturbance, as well as disturbance of an additional roughly 400 hectares for the main site access road, the rail spur, temporary construction phase facilities (e.g. construction personnel housing, storage and maintenance areas), permanent ancillary facilities, the perimeter fence and patrol road, etc. will differ between GRS construction and GRS operations. 


\subsubsection{Construction Phase}

As was discussed in the preceding section on impacts on floral communities, rectenna field site preparation will result in the complete removal of extant vegetation, with no vegetative recolonization expected at least until construction is completed. This will completely modify the existing faunal habitats of the rectenna field site. Further, clearing and grading will result in the virtually complete destruction of animals which are unable to flee to nearby similar habitats; only bird species and relatively large, mobile mammals can be expected to escape when threatened.

Significant losses of rabbits, rodents, ground squirrels and other small mammals can be expected, as well as losses to reptile species (most of the 31 species found in the study area would suffer population losses). No significant faunal recolonization would be expected during the GRS construction period because of the extensive soil disturbance and the subsequent construction activities.

Other disturbed areas (roads, rails, support facilities) al so would experience destruction of habitat and population losses among species that are unable to escape to adjacent habitats.

\subsubsection{Operations Phase}

Some degree of faunal recolonization will occur on the GRS site during operations, although the recolonized faunal communities may be different from the preconstruction communities. Within the 10,500-hectare rectenna field, faunal recolonization will depend on the nature and extent of revegetation, altered soil and microclimatic conditions, the direct effects of the rectenna structures, and the degree of continued human activity and disturbance during GRS operations.

Since vegetation is a major determinant of habitat conditions for animal species, the succession of plants which are reestablished on the GRS site is a most crucial parameter for the nature, extent and rapidity of faunal recolonization. Besides providing food for herbivorous species, vegetation provides shade and cover, affects animal mobility and stabilizes the soil (affecting burrow construction), among other functions. The degree of soil compaction in some areas and/or loss of soil cohesiveness in other areas also can affect animal mobility (e.g. ability to evade predators) and burrowing animals' ability to dig and utilize their burrows. Also, since thermal and drought stresses are critical to the adaptation of desert fauna, microclimatic changes under the rectenna panels may well affect faunal recolonization directly, as well as indirectly through effects on revegetation.

The rectenna structures themselves could directly affect faunal recolonization. Locomotion or flight, particularly for large species, could be restricted; the panels could serve as perching sites, shade or rest areas or nesting sites for various species. The entire rectenna field itself could visually resemble a body of water to bird species, which could attract them to the rectenna site.

Human activity and vehicular use during GRS operations could serve to inhibit or even prevent recolonization by some faunal species. This could stem from vehicle-caused mortality, as well as by species reaction to the noise, movement and mere presence of men and vehicles. 
Some faunal recolonization will occur during GRS operations in the areas disturbed by GRS development other than the rectenna field. The nature of the impacted soils in these areas and the floral succession that occurs are key determinants of faunal recolonization in these areas. Because these disturbed areas are relatively small (meaning that undisturbed areas are nearby) and because no significant microclimatic changes or extensive continuous disturbance will occur, faunal recolonization is expected to be more rapid than in the rectenna field. In addition, the expected minor enhancement of vegetation along the edges of the access roadway (perhaps in part because of increased water from roadway runoff) may have a minor positive impact on animal populations in the immediate area, largely because of increased availability of food.

\subsubsection{Summary of Direct Land Disturbance Impacts by Taxa - Construction and Operations}

Very few, if any, amphibians will be directly harmed by project land conversion, because the aquatic habitats of Rose Valley are sufficlently removed from the land areas that would be disturbed. However, a population of Great Basin spadefoot toads (Scaphiopus intermontanus) which were not observed but are considered likely to occur on the site, would likely be reduced. Virtually all reptiles residing in the disturbed areas would be lost. Although recolonization will be affected by as yet unknown microclimatic changes and revegetation, it may be that habitat alterations will be sufficient so that some some of the natural reptilian constituents of Rose Valley might be replaced by species from nearby areas that are better adapted to the altered conditions.

Virtually all of the adult birds in the areas to be cleared and graded will be able to escape to adjacent areas. However, these adjacent areas would then likely become overcrowded, with subsequent declines in the temporarily elevated population levels because of food competition, predation and other factors. Nests, eggs and flightless young would be destroyed during GRS clearing and grading. Birds would likely recolonize the rectenna field during GRS operations, but species compositon and the speed of recolonization would depend on the altered characteristics of the GRS site.

Small mammals, principally rabbits, small carnivores, ground squirrels and other rodents will suffer population losses in the areas that are cleared and graded for GRS construction. More mobile mammals, such as jackrabbits and medium-to-large-sized carnivores may successfully flee to nearby undisturbed areas. However, these escaping mammals may cause overpopulation problems in these new areas, which could cause declines from the temporarily elevated population leveis. Mammalian recolonization of the GRS site during operations will depend on alterations in microclimatic, physical, and vegetative conditions on the site.

\subsubsection{Indirect Impacts - Construction and Operations}

Potentially significant indirect impacts of GRS construction and operation could include alteration or loss of feeding areas for non-resident animal species; effects of air pollutant emissions, changes in water quality and/or availability and increased noise-levels; and disturbances associated with casual and recreational activities of on-site construction and operations personnel. 
The loss of vegetation and animal life associated with GRS development land disturbance will alter or destroy some of the feeding areas for mobile animal species that feed in the GRS site area, although they reside elsewhere in the . vicinity. The GRS perimeter fencing also will inhibit use of the site area.for feeding by large land mammals. The nêt effect of these factors will likely be a decline in the local populations of the affected species, such as raptors and other birds, as well as large carnivorous mammals residing in the Rose Valley vicinity, such as foxes, bobcats and ringtailed cats.

Increased air pollutant levels during GRS construction (particulates, nitrogen oxides and oxidants) could adversely affect local fauna. Operations phase emissions are not expected to be significant in terms of species impacts. Sensitive species habitat areas (discussed below) would be affected by projectcaused changes in water quality and availability for species dependent on the affected water supplies.

Noise generated by vehicles and equipment, primarily during GRS construction may affect local faunal communities. Recent studies by Bondello and Brattstrom (1979a) indicate that vehicular noise can affect desert vertebrates in various ways: loud noises can stimulate premature emergence of species such as spadefoot toads (which could result in death by crushing or by dessication if no water is present); hearing loss in small vertebrates could make them more susceptible to predation. In addition, noise and other disturbance could alter roosting, feeding and reproductive patterns for bird species, particularly raptors. For example, noise and human activity within one kilometer of nesting ferruginous hawks may prevent normal nesting (White, 1979). In general, noise will startle and disturb many bird and mammal species such that they avoid areas with project-caused elevated noise levels.

Casual and recreational activities by GRS construction and operations personnel, particularly if off Road Vehicles (ORVs) are involved, also could impact fauna in the GRS vicinity. As described in Section 4.6, ORV use could affect plant and soil resources, which in turn would affect fauna. Also, ORV and as sociated human noise could adversely affect animal species, as described above. In addition, GRS personnel conceivably could use the area for hunting and shooting; this could increase hunting pressures on various local species. As these personnel-related potential impacts can be considered proportional to the number of people present in the area, impact potential would be greatest in the GRS construction phase, because of the large construction work force.

Another impact associated with the large influx of people into a sparsely populated area is the unintentional introduction of non-native animal species, such as agricultural insect pests, rats and mice. Introduced species can cause ecological damage by competing or preying on native species, by introducing diseases, or by general maladaptation to their new habitats. For example, wild burros cause significant ecological damage in the general vicinity of the study site, although not in Rose Valley itself.

\subsubsection{Summary of Indirect Impacts by Taxa - Construction and Operations}

Amphibians could experience indirect impacts because of water quality degradation or reduction in surface water supplies, since these species breed in water and their larvae grow there. In addition, spadefoot toads could emerge from burial too early because of their reaction to construction noise. 
Extensive ORV use by project personnel or a significant reduction in the productivity of aquatic systems in the area could indirectly affect some reptilian species.

Bird species that use the rectenna field site as feeding areas will be adverse-ly affected; raptors and other birds that require large areas for foraging would be most affected. Some of these species may be able to use the rectenna field for foraging areas during operations, depending on the extent of floral and faunal recolonization that occurs. Many bird species, particularly migrating or wintering avifauna, would be adversely affected by any loss or degradation of water supplies. Raptors, as well as other bird species, also could be severely affected by project-caused noise and human intrusion in previously isolated areas. These factors could disrupt reproductive behavior; this problem would be of greater concern during GRS construction.

Mammals which range widely for feeding will suffer a significant loss in foraging area because of GRS construction; some of these mammals may be able to use the area again during GRS operations. In addition, mammals such as bats and carnivores would be scvercly impacted if local surface watcr resources were lost or degraded. Mammalian denning and reproductive behavior also could be affected by project noise and human intrusion.

\subsubsection{IMPACTS TO SENSITIVE FAUNAL AREAS AND RARE AND ENDANGERED SPECIES}

Important habitat areas in the Rose Valley vicinity which are most sensitive to the impacts of GRS construction and operation include Little Lake, the desert washes and playas of Rose Valley and the areas of Joshua Tree Woodland and rocky cliffs and slopes.

Little Lake, as described earlier, is a freshwater habitat and riparian plant community nearly unique in the region. Little Lake supports a fully developed aquatic community; serves as a source of drinking water for many animal species, as a breeding area for insects and amphibians, and serves as a feeding area for other species. Finally, it is especially important as a habitat for breeding, migratory and wintering birds, including numerous waterfowl.

Reduction of water levels at Little Lake could destroy the extant aquatic wildlife and riparian vegetation. Ultimately the lake could turn into a marsh or even a dry sink community. Thus to the extent that GRS development might cause a lowering of Little Lake water levels, extant species could be destroyed and all the aquatic, avian and terrestrial species that benefit from the lake's presence could be adversely affected. Erosion and inadequate waste control at the GRS site could cause the siltation and/or the eutrophication of the lake. These effects could degrade the lake as an aquatic community on which many local and migratory species depend.

The desert washes and playas in southern Rose Valley would be eliminated by clearing and grading associated with rectenna field development. Habitat areas for many reptiles and possibly some amphibians would thus be destroyed (desert washes) and migratory waterfowl will lose occasional water sources (playas).

A small area of Joshua Tree Woodland would be destroyed by rectenna field development: An important habitat for eight species of breeding birds thus would be lost. In addition, rocky hillsides and cliffs north and northeast 
of the rectenna field contain carnivore dens and raptor nesting sites and thus can be considered sensitive habitats. This denning and nesting activity could be affected by human intrusion and human and vehicular noise.

Several rare and/or protected animal species could be affected by GRS development in Rose Valley. The Mohave ground squirrel (Spermophilus mohavensis) is designated as rare by the California Fish and Game Commission and is protected by state law. The ringtail cat (Bassaricus astutus) and the desert tortoise (Gopherus agassizi) also are protected under California law, although not designated as rare. Further, the Panamint alligator lizard (Gerrhonotus panamintinus), may be found in the region, although it has not yet been reported in Rose Valley; this species is fully protected as an endangered species by both California and federal law.

The Mohave ground squirrel is relatively common throughout the Coso area, but is particularly abundant in Rose Valley: the Rose Valley population is at least as abundant as any population recorded to date. Almost 11,000 hectares (primarily the rectenna field) of its prime habitat in the northern part of its range would be destroyed by GRS development. It is expected that most of the existing population of that habitat will perish when the site is cleared. The alteration of the physical, microclimatic, and biotic environment of the rectenna field from its natural state during GRS operations may effectively limit recolonization from adjacent areas. Other rodent species, such as Spermophilus beccheyi which also occurs in the study area, may be able to replace the Mohave ground squirrel and exclude it from the altered habitat of the rectenna field.

Additional consideration may be required for the protected ringtail cat and the desert tortoise which were found in the study area. The ringtail cats were found in the hills east of Rose valley but might be expected to use Rose Valley for hunting their food. Therefore GRS development would affect the ringtail, at least during construction and the early years of operation, by the removal and alteration of feeding range. The desert tortoise, the California State reptile, was represented in the survey of the study area by one individual, sighted near Coso Junction (northwest of the GRS site). The GRS site is near the northern limit of the range of the desert tortoise in the western Mojave Desert. It is doubtful that any breeding populations in the western Mojave occur north of the Ridgecrest area (Berry, 1979); therefore, the individual found at Coso Junction may have been a vagrant or a released. pet.

The top predators of the food chains of the area, such as the large carnivore mammals and raptors, have naturally low population densities. Although there are no designated rare and endangered carnivores or raptors in the GRS study area, since populations of these species can suffer serious declines very rapidly as a result of pollution or habitat alterations, the regional status of populations of these species would have to be monitored through the various phases of GRS project planning and development to minimize potential impacts. 


\subsubsection{MITIGATION}

\subsubsection{Construction Phase}

Grading and clearing operations will totally alter the existing faunal habitat of the disturbed areas (over 10,500 hectares) by: removing all vegetation, eliminating intermittent surface water sources (playas and washes) and causing direct destruction of species that cannot escape to adjacent undisturbed areas. Once the precise location of the rectenna field is established, little can be done to minimize the habitat destruction, except to optimize the timing of construction activities to minimize some of the impacts. For example, initiation of rectenna field site preparation in mid- to late-summer would reduce the impacts of land disturbance and construction noise somewhat because faunal activity (e.g. feeding, breeding, nesting) is lowest at that time of year.

Other mitigation that could be undertaken during construction could include the use of site fencing that would permit passage of small to medium-sized animals (e.g. reptiles, rodents, rabbits, small carnivores). Further, impacts on the rare Mohave ground squirrel could be mitigated by a capture and release program initiated before rectenna field site preparation is begun.

The somewhat greater flexibility that is possible for siting roads and ancillary facilities might make it possible to minimize impacts on particularly sensitive and important faunal habitats.

To protect water resources on which local fauna depend, a program to monitor water levels in surface water bodies such as Little Lake and in wells that feed Little Lake would have to be undertaken. Further, measures to control water quality (e.g. proper wastewater disposal, erosion control) also would be necessary to prevent aquatic habitat and water supply degradation.

Construction personnel casual and recreational activities (e.g. ORV use, hunting, shooting) would have to be controlled. Any extant. rare or endangered species such as ringtail cats or desert tortoises lncated during construction would have to be protected from harm and relocated if necessary.

\subsubsection{Operations Phase}

It is assumed that the objective of a faunal mitigation program would be the reestablishment of faunal communities as close as possible to those that existed on the site prior to construction.

To a considerable extent this will depend on the course and success of revegetation efforts that are undertaken. Measures taken to hasten natural revegetation (if that proves feasible given both project impacts and project requirements such as fire protection and soil stabilization) would al so hasten natural faunal recolonization. For rare species, such as the Mohave ground squirrel, specimens could be relased into the area as part of a capture-release program. In addition, plant species of high food value to the Mohave ground squirrel could be selectively reintroduced. 
Other measures that could be undertaken include: rectenna maintenance programs and procedures that minimize disturbance to soils, vegetation and wildlife burrows; avoidance of introduction of non-native animal species; continued monitoring to prevent degradation of water resources; and monitoring of any. protected or rare animal species.

\subsection{LAND USE}

\subsubsection{INTRODUCTION}

This section addresses the expected land use related impacts of GRS construction and operation on the Rose Valley/Coso area and its surrounding region. Only impacts likely to be significant (i.e. those resulting in a one percent or greater change in existing uses or creation of new uses in excess of 10 hectares) are considered; these are summarized in Tables 4.8-1 and 4.8-2. In addition, non-quantitative issues and problems affecting land use (e.g., access, plans and policy, ownership, etc) are addressed where applicable to GRS siting concerns; these are listed in Table 4.8-2. Impacts are divided into two categories: di rect (e.g., those impacts resulting only from construction and operation of the GRS, generally limited to the rectenna field site and surrounding buffer zone) and indirect (i.e. impacts resulting from secondary activities related to or in support of construction and operation of the GRS, generally located off site in the surrounding region, but not within the control of GRS planners or operators).

For purposes of this analysis, the following assumptions regarding the proposed action have been made:

- the GRS project and facilities will have at least a 30 year life span;

- U.S. Highway 395 (and its associated land use features, such as the highway rest stop at Coso Junction, and existing rail lines and sidings) is relocated 16 kilometers west of the GRS site;

- water and aggregate for construction would be obtained locally (i.e. within the GRS study area);

- the BLM Coso Geothermal Leasing Program and the NWC Coso Geothermál Development Program are ignored (since these activities constitute a highly unusual and incompatible competing land use that would be obviated in actual GRS site consideration);

- the active GRS site will be unavailable for other land uses during the construction phase, and only non-human uses (e.g. water or cultural resource conservation) will be permitted within the site during the operations phase.

A complete list of assumptions concerning the socioeconomic impacts and indirect land use impacts is included as an appendix to this report. For purposes of clarification and simplicity, the following terms are used to identify and describe project-related geographic features: GRS site - the rectenna, collection and control facilities, buffer zone and perimeter patrol road, access road, railroad and sidings, and any other on-site support facilities, comprising roughly 15,600 hectares (see Figure 4.8-1); GRS study area - those 
Table 4.8-1. SUMMARY OF SIGNIFICANT QUANTIFIABLE DIRECT LAND USE IMPACTS

\begin{tabular}{lllll}
\hline $\begin{array}{l}\text { Impact Type } \\
\text { (incidence) }\end{array}$ & $\begin{array}{l}\text { Impact Phase } \\
\text { (C=construction } \\
\text { O=operation) }\end{array}$ & $\begin{array}{l}\text { Area Impacted } \\
\text { (hectares) }\end{array}$ & $\begin{array}{l}\text { Impact } \\
\text { Intensity } \\
(\% \text { impacted) }\end{array}$ & $\begin{array}{l}\text { Impact } \\
\text { Duration }\end{array}$ \\
\hline
\end{tabular}

New Uses

Rectenna Field

$\mathrm{C} / \mathrm{O}$

Buffer Zone

Borrow Pit

Support Facili-

ties (const.)

Perimeter Road

Solid Waste

Disposal

Access Rail Spur

Utility Corridor

Access Road

Support Facilities

(permanent)

$\mathrm{C} / 0$

C

$\mathrm{C} / \mathrm{O}$

$\mathrm{C} / \mathrm{O}^{\mathrm{C}}$

$\mathrm{C} / \mathrm{O}$

$\mathrm{C} / \mathrm{O}$

$\mathrm{C} / 0$

TOTAL

Displaced Existing Uses

\section{Grazing/}

Rangeland

Watershed

Management

Recreation

Military T\&E.

Historic Resource

Site

Mining/Mineral

Extraction

Utility Service

Corridor

Transportation

(dirt roads only) $\mathrm{C} / 0$

TOTAL 2
$\mathrm{C} / \mathrm{O}$

$C$

$\mathrm{C} / 0$

$\mathrm{C} / 0$

$\mathrm{C} / 0$

$\mathrm{C} / 0$

$\mathrm{C} / \mathrm{O}$
$10,500 / 10,500$
$4,700 / 4,700$
$200 / 0$

$100 / 0$

$50 / 50$

$30 / 1$

$20 / 20$

$20 / 10$

$15 / 15$

$5 / 5$

$15,600 / 15,300$

$15,500 / 15,300$

25

$2 / 30+$

$9,000 / 0$

$0,000 / 9,000$

$6,000 / 6,000$

$300 / 275$

$100 / 100$

100
$20 / " 100^{\prime \prime}$
100

$30+$
$30+$
2

100

100

100

100

25

100

$20+$

$2 / 30$.

$30+$

$2 / 30+$

$30+$

$30+$

100
2
$30+$
$30+$

$2 / 30+$

100

100

$30+$

$70 / 70$

$10 / 10$
25

25
$30+$

$30+$

1. Split figure or notation (e.g., 20/10) indicates impacts expected during construction and/or operation phases respectively.

2. Totals more than New Uses because of existing multiple and overlapping uses. 
Table 4.8-2. SUMMARY OF SIGNIFICANT QUANTIFIABLE INDIRECT LAND USE IMPACTS.

\begin{tabular}{lllll}
\hline $\begin{array}{l}\text { Impact Type } \\
\text { incidence, } \\
\text { use) }\end{array}$ & $\begin{array}{l}\text { Impact Phase } \\
\text { (C=construction } \\
0 \text {-operation) }\end{array}$ & $\begin{array}{l}\text { Area Impacted } \\
\text { (hectares) }\end{array}$ & $\begin{array}{l}\text { Impact } \\
\text { Intensity } \\
(\% \text { impacted) }\end{array}$ & $\begin{array}{l}\text { Impact } \\
\text { Duration } \\
\text { (years) }\end{array}$ \\
\hline
\end{tabular}

New Uses

Kern County

Urbanization

$\mathrm{C} / 0$

$60 / 180$

10

$2 / 50+$

Inyo County

Urbanization

$\mathrm{C} / 0$

$10 / 40$

100

$2 / 50+$

Construction

Housing (onsite) C

$20 / 0$

100

2

Rose Valley

Commercial

$c / 0$

$5 / 5$

100

$50+$

Transportation

$\mathrm{c} / 0$

$5 / 5$

100

$50+$

TOTAL

$100 / 230$

Displaced Existing Uses

Open Space

$\mathrm{C} / 0$

$70 / 220$

100

$2 / 50+$

Grazing

$\mathrm{c} / 0$

$30 / 10$

100

$2 / 50+$

TOTAL

$100 / 230$

$-$


portions of Rose Valley and the Coso Range immediately surrounding the GRS site, generally within $10 \mathrm{kilometers}$ of the center of the rectenna site and comprising a total of approximately 30,000 hectares (see Figure 4.8-1); and the GRS study region, the land between Lone Pine and Ridgecrest likely to be impacted as a result of the proposed action, comprising a total of approximately 8,000 square kilometers and roughly coincident with the socioeconomic study region considered in Sections 3.11 and 4.9 (see Figure 3.11-1).

\subsubsection{DIRECT IMPACTS}

Direct land use impacts resulting from construction and operation of the GRS are expected to be considerable because of the land-intensive nature of the project. To simplify the analysis, impacts are considered in two categories: 1) new land uses created by construction and operation of the GRS, and 2) existing land uses which are displaced or significantly altered as a result of the project; these impacts are summarized and quantified in Table 4.8-1. Other direct impacts of a more subjective nature are considered separately and are listed in Iable 4.8-2.

\subsubsection{New Use Direct Impacts}

New land uses created as a direct result of the project will total approximately 15,600 hectares, as shown in Figure 4.8-1. The major new land use is, of course, the GRS rectenna field, covering and disturbing completely more than 10,500 hectares of land (105 square kilometers). This new use impact will occur both during construction and operation phases and is expected to continue throughout the project life of 30 years or more; the intensity of this use is total (i.e. 100 percent of the land is in full-time use as a rectenna site during all project phases) and would exclude all other possible coincidental uses. (As stated in Section 1.3, possible concurrent land uses are not addressed in this study.)

The other major new use is the GRS site buffer zone, an area extending 1.0 to $1.4 \mathrm{kilometers}$ beyond the edge of the rectenna field and comprising another 4,700 hectares of only partially disturbed land. Although the buffer zone will occupy the full 4,700 hectares for 30 years or more, certain limited multiple land uses (e.g., watershed, cultural resource, and natural resource management) are possible during the operations phase as a result of the limited amount of surface disturbance and occupance within the buffer zone, exclusive of the perimeter and connecting roads. Because of concerns relating to microwave exposure, it is assumed that the buffer zone will be unavailable for human uses during the operations phase.

Other new uses (mainly construction-related facilities) would total roughly 400 hectares, and most of this land, although intensely used during the construction phase, would become available for non-GRS uses during the operations phase, assuming proper restorative and clean-up measures are applied. The borrow pits needed to provide most of the required gravel, sand, and construction aggregate, would occupy at least 200 hectares and create a pit more than 10 meters deep (ignoring unwanted overburden and waste materials); it would be located off the GRS site, preferably within a few kilometers of the access road or rail line. Reclamation of the pit and return to previous or new uses could also occur once construction was completed. Other uses, such as the access road, rail spur 


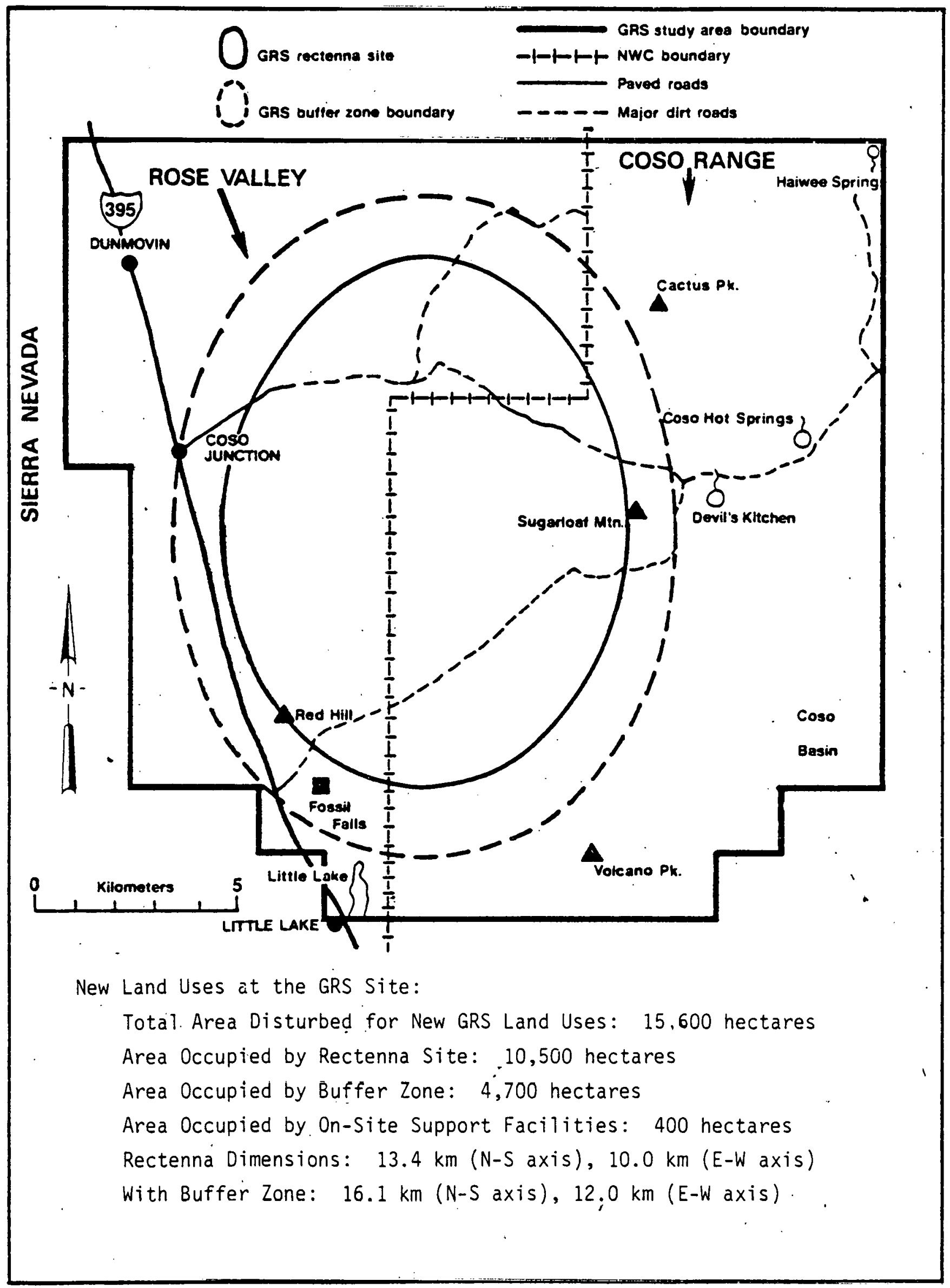

Figure 4.8-1. IMPACTS OF NEW LAND USES 
line, perimetèr road and fence, and GRS utility service corridor, would be permanent (i.e. 30 years or more) and would create high intensity use and surface disturbance, precluding coincident multiple uses during both construction and operation phases.

\subsubsection{Direct Displacement Impacts}

Existing land uses within the study area that would be displaced or significantly disturbed as a direct result of GRS development would total roughly 40,000 hectares during the construction phase and over 30,750 hectares during operations; these are identified in Table 4.8-1. The total displacement equals more than twice the total new project use because of pre-existing multiple uses within the GRS site (e.g. grazing, watershed, recreation).

Grazing and rangeland would suffer the greatest change, 15,000 hectares longterm loss during the 30 plus years of project life, since the GRS site is located entirely within the Tunawee Common and Lacey-Cactus Flat-McCloud grazing allotments. The potential magnitude of this impact is considerably diminished when one considers the relatively low range carrying capasity nf the land (less than one animal-month-unit per 10 hectares on average), the seasonal use (overall use intensity is 10 percent or less), and the enormous amounts of grazing land (more than 210,000 hectares) within the surrounding region. Grazing patterns and cattle movement also would be affected by the existence of the perimeter fence and fences along the access road and rail spur (at least during the construction phase) and possibly disturbed by the noise and dust of construction activity.

Watershed management (in the form of about 9,050 hectares of Protective Water Withdrawal within the GRS site) would be completely disrupted for two years during construction as a result of site grading and construction activities. Assuming that adequate flood control and runoff mechanisms are incorporated into facility design, there should be few adverse impacts remaining during the operation phase. It is entirely possible that watershed management and water resource control would be enhanced by runoff collection and conveyance systems associated with the site; it is also possible that disruption of natural percolation and runoff patterns could result in adverse impacts on ground water quality and quantity; see Section 4.5 (Hydrology) for further discussion of these issues.

The impact of the loss of potential recreation land uses (mainly sightseeing and off-road vehicle tracks) amounting to nearly 9,000 hectares during both construction and operation would be offset by the fact that less than five percent of this land actually is in recreational use. The notable exception occurs around Fossil Falls, at the southwest corner of the GRS site, where an important and intensely used mult $i$-recreation area covers approximately 100 hectares, lying within the buffer zone.

Military testing and evaluation (T\&E) uses within the 6,000 hectares of Naval Weapons Center (NWC) land covered by the GRS site would have only a minor impact on T\&E activities because of the low intensity use (10 percent) of this land as a safety and security buffer zone for NWC operations. Of greater significance is the possibility, however remote, of T\&E activity impact on the GRS site and facilities as a result of a stray drone aircraft or test weapon crashing into sensitive equipment, such as the rectenna panels and power collection network. 
Serious, unavoidable impacts would accrue to various historic/cultural resoure site management uses, particularly at the 300-hectare Fossil Fall Archaeologic District (which has been nominated for inclusion in the National Register of Historic Places) and the approximately 10 hectare Coso Native American Prayer site (which is already listed on the National Register). These sites, located at the southwestern and eastern edges respectively of the GRS site, would be completely impacted during the construction phase because of access denial and construction activity. Approximately 275 hectares of the Archeological District would be permanently impacted (destroyed) by construction and operation of the rectenna, while the Prayer Site and 25 hectares of the Archaeological District would be preserved (and protected from vandals) within the GRS buffer zone.

Other displaced use impacts would be rather minor, covering 100 hectares or less, but would persist throughout project life. Approximately 100 hectares of pumice, cinder, and perlite surface mines would be destroyed; 70 hectares of utility transmission corridor rights-of-way would have to be re-routed, and five hectares of dirt roads (mainly used for access to mines, historic sites, and grazing areas outside the GRS site) would be destroyed.

\subsubsection{INDIRECT IMPACTS}

Indirect land use impacts created by GRS construction and operation would be generally minor and mostly focused offsite, in the Ridgecrest/Indian Wells Valley (Kern County) and 01 ancha/Cartago (Inyo County) areas. Most impacts would result from project-generated population influx and the subsequent need for additional residential, commercial, and public service facilities to support the increased population. These impacts are summarized in Table 4.8-2; a more complete presentation of the basis for determination of these impacts is contained in Section 4.9 (Socioeconomic Impacts) and in the report Appendix on demographic and economic assumptions.

\subsubsection{New Use Indirect Impacts}

New land uses created as an indirect result of the project would total approximately 100 hectares during the construction phase and over 200 hectares during operations; these new land requirements (mainly urban facilities) are characterized by high use intensity (100 percent) which is generally incompatible with multiple use concepts. Except for the temporary onsite construction worker housing, all uses are expected to endure exclusively for 50 or more years, since they are only indirectly associated with the project and its 30-plus year life span.

The major new indirect land use would be for urbanized lands (residential, commercial, governmental, industrial, and transportational uses). Within the Ridgecrest/IWV area this would involve roughly 60 and 180 hectares respectively during construction and operations, and within the 0lancha/Cartago area, 10 and 40 hectares for construction and operations phases respectively. The greater land use requirements during the latter phase is a result of residual population remaining after construction, as discussed in Section 4.9. From Table 3.10-1 it can be seen that ample land for new urban use purposes exists within these areas--in fact, current Ridgecrest and Kern and Inyo County zoning laws have designated and reserved several hundred hectares for such 
future uses. Thus, the overall and long-term impact of increased urbanized land uses is expected to be slight; see Table 3.10-1 to determine the actual land requirements for each urban use category. (This was estimated by multiplying anticipated population increases by the present average per capita land requirement for that. use.)

All other indirect new uses are minor. Temporary residential needs of construction crews and their families will require development of a Recreational Vehicle/trailer park-type facility estimated to require about 20 hectares on the GRS site (most likely within the buffer zone). Some additional commercial service facilities (gas stations, motels, stores, bars, etc.) would likely develop in or near Rose Valley, requiring an additional 5 hectares; this new use would probably remain for the full project life, to service both operation phase personnel and transiting tourists. Because of increased traffic loads generated by GRS construction needs and commuting workers on Highway 395 and 14 (see Section 4.9.4), the local transportation network might have to be expanded to include an additional 50 kilometers of four-lane, divided highway; this would require an additional five hectares of land, to be used exclusively for transportation over a period of 50 plus years.

\subsubsection{Indirect Displacement Impacts}

Existing land uses likely to be displaced as an indirect result of the GRS' project include roughly 70 hectares of open space/no designated use lands in the Ridgecrest/IWV and 01 ancha/Cargago areas during the construction phase and 220 hectares during operations; the loss of this land use would be of little consequence, since it would be displaced by urbanized uses al ready designated but not presently implemented. The loss of 30 hectares of grazing/ range use lands (mostly in the Rose Valley area) would create a minor impact as it would be displaced by expanding commercial and transportation uses and the temporary construction residential facility; this displaced use impact would decrease to 10 hectares during the operation phase after the residential facility is removed and the land restored to its original use (grazing).

\subsubsection{NON-QUANTIFIABLE IMPACTS AND ISSUES}

In addition to the easily measured and quantifiable impacts of project construction and operation activities on new and displaced land uses, a number of significant impacts and issues of a more subjective nature also emerge; these are summarized in Table 4.8-3. In addition to identifying and characterizing these impacts and issues, an attempt has been made to define the probable recipient of such impacts and to predict the likely impact magnitude in subjective terms. It should be emphasized that, merely because these impacts/issues are of a nonquantifiable nature does not make them any less significant as items of concern to project designers and decision makers; to the contrary, a number of these impacts/issues potentially pose severe constraints on GRS construction/operation plans and activities.

Availability of land and acquisition of land for siting is a major issue at the Rose Valley/Coso site and would be so at almost any other potential site. As shown in Figure 3.10-3, 56 percent of the GRS site (approximately 8,500 hectares) lies within "public. lands" administered by the U.S. Bureau 
Table 4.8-3. SUMMARY OF SIGNIFICANT NON-QUANTIFIABLE LAND USE ISSUES AND IMPACTS

-...ract Focus

Impact Phase

Potential

( $C=$ const ruct ion

Impact Recipient

Impact

$0=$ operation)

Direct Impacts/Issues

Land Availability/Acquisition

C

BLM, NWC, LADWP,

major

private owners

Property Values

$\mathrm{C} / 0$

private owners,

taxing agencies

variable

Access Alteration/Denial

$\mathrm{C} / 0$

Coso Hot Springs,

major

Register Site, mining

Magnitude

and military operations

Alternate/Future Land Uses

0

geothermal, farming, unknown mining, recreation

Water Competition Effects

$\mathrm{C} / 0(?)$

agriculture, ranching, mining

Natural Landscape Values

$\mathrm{c} / 0$

sightseers, tourists, residents

major

Land Use Plans/Policy

$\mathrm{c} / 0$

Federal, state, county minor agencies

Wilderness Values

$\mathrm{C} / 0$

Wilderness Study Area major 157

Native American Values

$\mathrm{C} / 0$

Owens Valley Shoshone- major Paiute

Indirect Impacts/Issues

Land Availability/Acquisitio

$\mathrm{C} / 0$

private property

owners

slight

Property Values

$\mathrm{c} / 0$

property owners,

taxing agencies

Water Competition Effects

$\mathrm{c} / 0$

residents of Indian

Wells Valley

Land Use Plans/Policy

$\mathrm{C} / 0$

county and local

agencies

minor

various urban land uses

minor

slight

Alternate/Future Land Uses

unknown 
of Land Management (BLM); presumably these lands could be acquired by withdrawing them from the public domain in support of an energy resource development project of national significance under the provisions of Section 204 of the Federal Land Policy and Management Act (FLPMA). Acquisition of the approximately 6,000 hectares of Naval Weapons Center (NWC) lands would pose far greater difficulties; the Navy (and the military in general) is extremely concerned about potential "encroachment" on lands used for military purposes, even though these are mostly public lands previously withdrawn for military uses. The remaining land within the GRS site ( 440 hectares of privately owned land and 150 hectares owned by public and private utilities) could presumably be purchased or even acquired by condemnation procedures under federal powers of eminent domain, although the latter acquisition method would be costly, protracted, and likely to generate strong public opposition to the project. Because of the extremely limited amount of privately-held land available within the study area (less than 5 percent) and the Basin and Range Province in general (approximately 20 percent), acquisition of privatelyowned land for large-scale, land-intensive public projects like the GRS would meet with significant opposition. A movement to remove from Federal authority large areas in the Western states has emerged recently and is becoming known as the "Sagebrush Rebellion". Availability of land for off-site uses (housing, urban growth, etc.) in the Ridgecrest/IWV and 01 ancha/Cartago areas would not be a problem and no impact. wnuld be expected.

Changes in property values resulting from GRS siting in the study area would be likely, but the type and magnitude of such impacts are difficult to predict. On the one hand, pressures to develop commercial service and support facilities within the area (especially during the construction phase) may drive up demand (and hence, value) for the limited amount of private property, resulting in increased valuation for taxation purposes and a rise in county and local property tax revenues; on the other hand, concerns related to the effects of microwave radiation or dislike of development and degradation of the rural, almost primitive atmosphere of the area (strongly preferred by local residents) could cause property values to fall during both construction and operation phases. In the Ridgecrest/IWV area, demand for new urban land would doubtless result in significant increases in property values throughout project life.

Alteration or denial of access to other land uses within the vicinity as a result of GRS siting potentially could create a major impact. Using the present siting configuration in the Rose Valley/Coso area would destroy the only roads leading to mining operations at the north end of the study area, to the National Register Site at Coso Hot Springs, and the only western entrance to NWC test ranges and weapons recovery zones. Realignment or reconstruction of these roads would be impossible because of the rugged relief and topographic limitations of the surrounding area, effectively destroying land use dependent on such access.

Alternate, future, and cullipdible multiple land uses create a series of issues and potential impacts for both construction and operation phases; however, it is difficult to assess the magnitude of such impacts or to determine specific conflicts because of the large number of variables involved. However, within the GRS site, the following alternative and potential future land uses (all of which are incompatible with GRS construction and operation) are possible: geothermal energy development, expanded irrigated agriculture and cash crop 
farming, mining of various minerals and construction materials, and expanded recreation facility development. Presumably such uses would have to be foregone if the GRS project were to proceed, requiring policy decisions and long-term commitment of land resources by planning and management agencies.

Closely related to alternative land use conflicts are those impacts created by competition for available water resources. Throughout the arid Basin and Range Province, the major land use (and urban growth) limitation is that imposed by the availability of sufficient quantities of high quality surface and ground water; the Rose Valley/Coso area typifies this problem. If large amounts of ground water were used for the GRS project, the subsequent drawdown of the water table would effect not only natural vegetation and wildlife, but agriculture, mining, and grazing uses as well, since the latter activities depend totally on pumped ground water as a source of supply. See Section 4.5 (Hydrology) for a discussion of this issue and the related possibility of water quality deterioration within the study area. Similar problems of water supply availability would place limits to urban growth and population expansion in the Ridgecrest/IWV area, since that area is expected to reach maximum local water supply limits by 2020, even without the added demand of GRS-induced growth.

The GRS study area, like much of the Basin and Range Province, represent a land use and aesthetic resource in the form of an open, relatively undisturbed landscape. The value of a natural landscape (even an arid desert valley) is a completely subjective issue; but, like property values, landscape aesthet ic values are very much subject to impact from development, especially a totally new (and alien) use on the magnitude of the GRS project. Section 4.13 (Visual Resource Impacts) considers this effect in more detail.

Closely related to visual impact is the issue of potential project impact on wilderness lands and wilderness values surrounding the GRS site. The 10,000 hectare Wilderness Study Area (WSA) 157 lies immediately to the west (and in full view) of the GRS and its support facilities; see Figure 3.8-2. Construction phase activities would have a severe, if temporary, impact on the "naturalness and opportunity for solitude and primitive, unconfined recreation (as defined by the Wilderness Act of 1964) on WSA 157. Even the relatively passive GRS operation phase (largely devoid of noise and air pollution) would create a major impact by their mere presence; the rectenna, transmission lines, and support facilities would provide a highly visible and constant intrusion on the naturalness, solitude, and primitive character of WSA 157. Other WSA's and designated Wilderness Areas within the surrounding region (see Figure 3.10-1) would only be indirectly impacted by the GRS project; such impacts, caused by increased traffic, noise, and air pollution along Highway 395 and by increased visitor use of these areas, would be minor and limited to the construction phase.

Land use plans and policies governing the GRS site and surrounding region could conceivably be impacted if they failed to anticipate or take into account the land use changes and population growth effects of the GRS project. Most of these impacts would be indirect and minor, primarily a matter of altering zoning and land use plans to reflect the reality of accelerated growth in Rose Valley, Ridgecrest/IWV, and 0lancha/Cartago. Presumably, project planners would be required to abide by all existing federal (BLM California Desert Plan), regional 
(IMAGE Master Plan), county (Inyo and Kern County General Plans), and local (Ridgecrest and Naval Weapons Center Master Plans) land use requirements and restrictions or obtain necessary variances and conditional use permits as appropriate.

Although Native Americans have been land users within the Rose Valley/Coso area (and the entire Basin and Range Province) for thousands of years, their traditional use patterns and unique land use values are usually ignored or given low priority by non-Indians. Portions of the GRS study area, especially those around Coso Hot Springs, are considered sacred by the Paiute-Shoshone Indians of Owens Valley, who continue to visit the Hot Springs area regularly to conduct ceremonies of religious, cultural, and therapeutic significance to their tribal group. Many of the older Native Americans feel that the spirits of their ancestors still reside at Coso; in fact, several aboriginal burial sites have been discovered in the vicinity, and the entire study area (including the GRS site) is rich with the archaeologic remains of prehistoric Indian use and settlement. Construction of the GRS would not only destroy many sites of prehistoric significance to Native Americans, but also would prevent road access to the Coso Hot Springs/Devil's Kitchen area (see Figure 4.8-1); the associated Prayer Site would be enclosed by the buffer zone fence, removing it from use by Native American visitors. Perhaps the greatest impact would involve Indian attitudes and public opinion: for over 35 years the Paiute-Shoshone have fought with the Naval Weapons Center and BLM to maintain regular access and use of traditional lands near the GRS; for the GRS project to propose a 30-year or more closure of these lands would create a major public outcry and opposition to the project.

\subsubsection{MITIGATION}

There are only limited measures which could be taken to mitigate or moderate land use impacts of this project. The most obvious measure, relocation or realignment of the GRS site, is, of course, irrelevant to this study. However, the magnitude and range of land use impacts created by a project of this scope and area extent (land disturbance and loss of existing multiple land uses could total over 30,000 hectares), serve to emphasize the importance of initial site selection and the development of suitable siting criteria to obviate the likelihood of severe conflict or reduce the magnitude of unavoidable potential impacts.

\subsubsection{Mitigation of Direct Impacts.}

New land uses resulting from construction of the rectenna will result in complete disruption and replacement of most previous uses of this 10,500 hectare area; no mitigation of these impacts is possible without re-siting of the facility in an area where there are fewer pre-existing land uses or a lower ratio of multiple co-existent uses.

Mitigation of many impacts within the 4,700 hectare buffer zone would be possible if occasional human use and access to this area were allowed. For example, the entire area could be returned to use as productive rangeland for cattle and sheep grazing (although this would also require that another fence be built to surround the rectenna.). Provision of special protective equipment and visitor access periods would partially mitigate the loss of various archaeological sites and the Coso Prayer Site to the buffer zone; again, this may not be a cost-effective measure, but it would be an important factor in reducing public. opposition based on land use impact issues. 
The remaining new use impacts, approximately 400 hectares of construction and operation support facilities, could be mitigated or even avoided by locating such facilities within the buffer zone or along immediately contiguous areas which have low land use value; facility location planning could also reduce other types of impacts (e.g., transportation, air pollution) by placing construction and operation control buildings, worker residences, etc. at those points on the GRS site which are closest to local population and construction supply centers.

\subsubsection{Mitigation of Indirect Impacts}

Because most indirect land use impacts are created by the requirement for expansion of urbanized areas to support project-related population increases, little could be done to avoid such impacts beyond reducing the peak construction work force (by extending the construction phase beyond two years). The rather slight magnitude of these impacts might be altered by shifting the geographic focus of secondary growth and development away from the Ridgecrest/ IWV and 0lancha/Cartago areas to completely undeveloped land within Rose Valley (i.e. creation of new "urban centers" closer to the project site); in the long run, however, such redirecting of indirect development would probably create more land use (and other) problems than it would solve, since it would also require the development of complete urban infrastructures and new land uses where none previously existed.

\subsubsection{Mitigation of Subjective Land Use Conflicts and Issues}

Although little (beyond site relocation or realignment) can be done to mitigate or moderate impacts on land use related issues such as land acquisition, property value alteration, wilderness value degradation, policy conflicts, and alternate/future uses, a few of the subjective conflicts are subject to migitation measures.

Access denial, created by destruction or interruption of roads and surface travel routes to the north and east of the GRS site, could be solved by construction of new roads into the Coso Range and the Coso Basin (especially to Coso. Hot Springs) from the 01 ancha area (30 kilometers to the northwest) or the Pearsonville area ( $15 \mathrm{kilometers} \mathrm{to} \mathrm{the} \mathrm{south).} \mathrm{Such} \mathrm{roads} \mathrm{would} \mathrm{be} \mathrm{both}$ difficult and costly to construct because of the rugged topography of the coso Mountains.

Water competition effects (both quantitative and qualitative) induced by land use decisions could be moderated or eliminated by importation of water from sources beyond the Rose Valley, such as the Owens Lake Bed, the Kern Plateau, or adjacent unused hydrologic basins on Naval Weapons Center lands. However, such a water transport system would not only be expensive to construct (extensive pumping, conveyence, and storage facilities would be required), but exportation of water from anywhere within this semi-arid region would simply create another set of impacts, perhaps as great as those encountered within the GRS study area. Impacts to natural landscape values could be moderated by special design and construction measures which would allow the GRS facilities to blend as naturally as possible into, their surroundings. For example, gently sloping berms or screening vegetation could be developed around the rectenna field to hide it from view, panels and electric collection/transmission systems could be painted a dull buff color to blend with the natural background, and construction and storage facilities conceivably could be sited within adjacent canyons to remove them from the general viewshed of Rose Valley. Again, such measures would be quite expensive, and their cost-effectiveness is debatable. 


\subsection{SOCIOECONOMICS}

In order to simplify the analysis of GRS socioeconomic impacts, a number of assumptions have been made and are discussed at length in Appendix B. The key assumptions are related to employment multipliers, employment inmigration, materials purchases, employee expenditures, and project ownership.

- For purposes of this study the employment multiplier is assumed to be 1.2 during construction and 1.8 during operations, i.e. 100 direct GRS construction jobs would generate 20 additional indirect jobs in. the local area and 100 GRS operations jobs would generate 80 additional jobs.

- Local residents are assumed to take 20 percent of the 2,500 (average) construction jobs, while another 10 percent would be taken by daily commuters from the Antelope Valley, some 150 kilometers to the south. The remaining 1,750 construction workers (70 percent) are dssunled to inmigrate to the study area. At peak construction (total workforce of $3,200)$, an additiunal 700 workers would inmigrate to the area.

- All of the 450 operations workers are expected to move into the study area from outside.

- Inmigrant workers and their families are assumed to distribute themselves to existing communities in the area: 80 percent to the Ridgecrest area and 20 percent to southwestern Inyo County.

- It has been assumed that 15 percent of both construction and operations phase materials purchases will be made in Kern or Inyo County.

- Permanent inmigrants and long-term construction workers are assumed to spend 70 percent of their disposable income locally; short-term construction workers and daily commuters are assumed to spend locally 35 percent and 5 percent, respectively, of their disposable incomes.

- Finally, the project is assumed to be publicly owned, which would exempt. the project from property taxation and sales taxation.

As noted above, this analysis assumes that all GRS-related population growth, along with the associated housing, and infrastructure requirements occurs in existing communities. In the Coso study region this is a reasonahle assumption since communities exist that could absorb the required growth, with relatively minor impacts. To the extent that GRS siting occurs in areas where the population base of existing communities is even smaller than in the coso area (and where virtually 100 percent of the construction workforce would have to be imported into the region), the impact on local socioeconomic. conditions (the requirement for new housing, schools, hospitals, etc.) obviously would be greater than in the Coso area. In essence, the smaller the existing population base, the greater would be the socioeconomic impacts of GRS siting: The impact of rapid growth in sparsely populated areas could create a "boomtówn" situation. This boomtown phenomenon has become increasingly familiar in the context of major energy development projects in the rural West. 'In a number of well-known cases (e.g. Rock Springs and Gillettte, Wyoming; Colstrip, Montana), growth impacts have overwhelmed the local economic, public service 
and social infrastructure with attendant price inflation, housing shortages, social disruption, and a perceived overall decline in the quality of life. Ultimately, GRS development in an area with an extremely small population base could require devel opment of a totally new community. The costs and problems of creating a new community where none existed, of course, would be considerable.

Estimation of the socioeconomic impacts of GRS construction must be done by two different methods. For the portion of the existing social infrastructure that is most affected by the peak construction period (e.g. police, fire, traffic, hospitals, etc.) impacts are calculated from peak construction phase inmigration (the nine-month period when the GRS construction work force peaks at 3,200$)$. For the social infrastructure and economic variables that are most affected by the two-year construction period (liquid and solid wastes, fresh water, public revenues and expenditures, etc.), the impacts are calculated based on the average construction phase inmigration (workforce of 2,500$)$.

\subsubsection{POPULATION}

\subsubsection{Construction}

Over the two-year GRS construction period, construction employment would average 2,500 with a peak of 3,200. Of the 1,750 inmigrant workers, 1,400 (70 percent of the total) are assumed to live in temporary housing provided at the construction site and 350 in Ridgecrest and southwestern Inyo County. Of the 350 inmigrant construction workers living off-site, 150 would live in transient housing (e.g. motels), and would not relocate their families. The remaining 200 construction workers would relocate their families to the study region and reside in permanent housing, as their services would be required for a two-year period. During the peak construction period, an additional 600 workers would 7 ive in the construction camp (a total of 2,000) and an additional 100 workers would live in transient housing (a total of 250).

Construction phase project-induced employment would total 500. Of this total, 100 positions are assumed to be local hires. The remaining 400 positions are assumed to be filled by inmigrant workers who would relocate with their families to permanent housing within the study region; these workers are assumed to remain during the GRS operations period to serve operations-related growth. A household size averaging 2.70 persons was assumed for inmigrant families of both direct and indirect employees.

The average GRS-related population increase during the construction phase would total about 3,200, while the population increase during the peak construction phase would be approximately 3,900. The average increase would represent approximately 11.6 percent of the total study area's 1977 population $(27,259)$; Project construction would increase population in southwestern Inyo County by about 330 , which would represent a 12.9 percent increase above its 1977 population. (The roughly 1,400 people who are expected to live in the onsite temporary housing facilities, in a sense, also can be considered southwestern Inyo County residents, but are not included in the 12.9 percent population increase.) The total of about 1,750 construction 
phase inmigrants into Inyo County would represent nearly 10 percent of total 1977 Inyo County population. The City of Ridgecrest would experience an increase of about 1,300 people $(1,400$ including short-term inmigrants), equalling 8.5 percent of that City's 1977 population. Table 4.9-1 summarizes GRS construction and operations phase population growth.

\subsubsection{Operations}

The operational employment requirements of this project would be the equivalent of 450 full-time positions. These positions are assumed to be filled by inmigrant workers, who would relocate their families to permanent housing within the area of project influence.

Using a household size of 2.7 , the GRS operations permanent population increase within the study region would be approximately 2,300 people. This would represent 8.4 percent of the study area's 1977 population. The population increase attributable to GRS operations personnel and their families would be 1,200 of the 2,300 increase, with the remaining 1,100 comprised of workers (and their families) taking project-induced jobs. As in the analysis of construction impacts, 80 percent of the inmigrant population in permanent housing is assumed to locate in the City of Ridgecrest, while the remaining 20 percent would locate in southwestern Inyo County. Given this breakdown, the City of Ridgecrest would receive an increase of approximately 1,800 people, representing 11.6 percent of its 1977 population. Southwestern Inyo County would experience a population increase of about 460 , representing a 17.8 percent increase over its 1977 population, and 2.6 percent of Inyo County's total population.

Indirect employment in the retail and wholesale trades induced by project operational expenditures was estimated to be 360 permanent jobs. These jobs were assumed to be filled by 360 of the 500 indirect employees hired during the project's construction period.

\subsubsection{HOUSING}

GKS development would produce impacts on housing stock within the study area both during project construction and operations. Additional temporary and permanent housing would be required to accommodate transient construction workers, as well as long-term construction workers and their families during the construction period. Additional permanent housing would be required to accommodate inmigrant operations workers and their families during the GRS operations phase. Table 4.9-2 presents construction and operations phase housing requirements by geographic location.

\subsubsection{Construction}

It is assumed that onsite temporary housing would be provided to accommodate a construction phase peak of 2,000 workers. Assuming a ratio of 1.4 workers per unit, over 1,400 temporary units would be required at the project site. Some mix of Recreational Vehicle hookups (i.e. water and electricity), and mobile homes/trailers is considered likely. It is assumed that an additional 150 construction workers (250 during the construction peak) would utilize existing transient housing in southwestern Inyo County and in the RidgecrestInyokern area. Assuming 1.4 workers would occupy each unit, about 85 transient units would be required on average, and 143 units would be required during 
Table 4.9-1. CONSTRUCTION AND OPERATIONS PHASE POPULATION IMPACTS

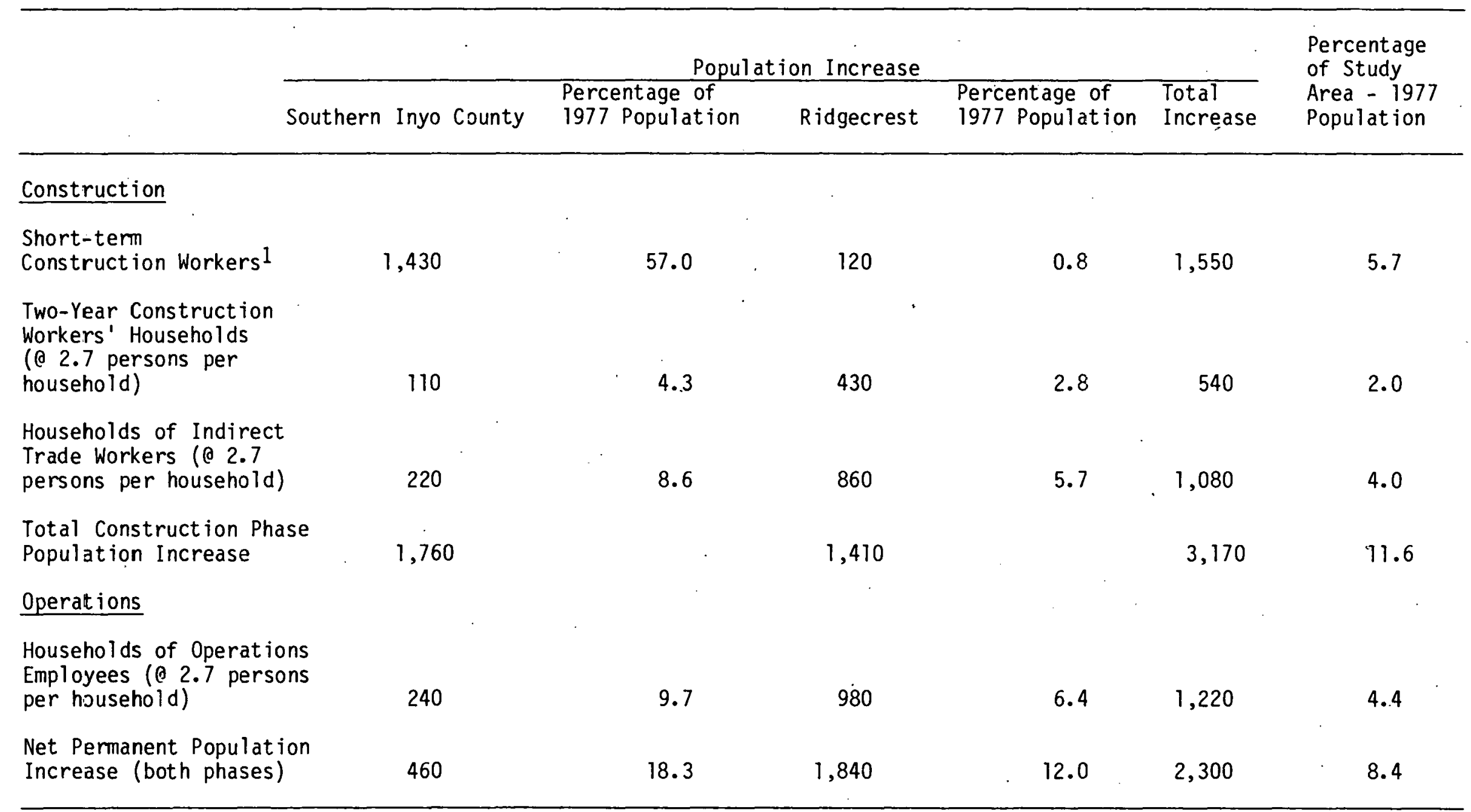

1. Average conditions, includes GRS onsite temporary housing for construction personnel. 
Table :4:9-2. PERMANENT HOUSING REQUIREMENTS DF GRS CONSTRUCTION AND OPERATION

\begin{tabular}{|c|c|c|c|c|c|c|c|}
\hline & \multicolumn{3}{|l|}{$\cdots$} & it Units Requ & ired & & \multirow{2}{*}{$\begin{array}{l}\text { Percentage } \\
\text { of Total } \\
\text { Housing } \\
\text { Stock }\end{array}$} \\
\hline . & Southern & Inyo County & $\begin{array}{l}\text { Percentage of } \\
i 97 ? \text { Housing } \\
\text { Stock }\end{array}$ & Ridgecrest & $\begin{array}{l}\text { Percentage of } \\
1977 \text { Housing } \\
\text { S-ack }\end{array}$ & $\begin{array}{l}\text { Total } \\
\text { Increase }\end{array}$ & \\
\hline \multicolumn{2}{|l|}{$\begin{array}{l}\text { Households of } 2 \text {-year } \\
\text { Construction Workers }\end{array}$} & 40 & 3.0 & 160 & 3.4 & 200 & 3.3 \\
\hline \multicolumn{2}{|l|}{$\begin{array}{l}\text { Households of Indirect } \\
\text { Trade Workers }\end{array}$} & 80 & 6.0 & 320 & 6.8 & 400 & 6.7 \\
\hline \multicolumn{2}{|c|}{$\begin{array}{l}\text { Households of Operations } \\
\text { Employees } 1\end{array}$} & 50 & 3.7 & 200 & 4.3 & 250 & 4.2 \\
\hline $\begin{array}{l}\text { Total Permanent Housi } \\
\text { Requirement }\end{array}$ & & 170 & 12.7 & 680 & 14.7 & 850 & 14.2 \\
\hline
\end{tabular}

1. Incremental requiremerit only, as 200 units lacated by 2 -year construction enployees would be occupied by 200 of the incoming oferations employees. 
peak conditions in the Ridgecrest-Inyokern area. In southwestern Inyo County, 21 and 36 units would be required during average and peak conditions, respectively. The required units could be provided in the form of hotels, motels and other short-term rentals. It is expected that existing transient housing units would be able to meet this need, as these requirements are relatively small.

Permanent housing would be required during the construction phase to house 200 long-term construction workers who would reside in the project area for two years. Permanent housing would also be required to accommodate the 400 relocated households representing indirect employment induced by project construction. It was assumed that these households would require permanent housing as they would remain in the project area after the construction period to serve operations phase-related growth. In total, 600 permanent housing units would be required in the project area during the construction period. Construction period permanent housing requi rements in Ridgecrest would be an increase of 480 units, representing 10.3 percent of that City's total housing stock in 1975. In southern Inyo County 120 units would be required, which represents 9.0 percent of 1977 total housing stock.

\subsubsection{Operations}

Project operations would require 450 permanent employees, all of whom are assumed to relocate, with their families, to the study region. Indirect employment requirements for project operations would not add to inmigrant population, since the 360 positions generated by operations phase expenditures are. assumed to be filled by 360 of the 500 indirect workers who had relocated to the area to accommodate temporary construction phase growth.

The 450 households of inmigrant operations employees would require permanent housing in the project area. It was assumed that the 200 permanent units vacated by construction phase workers who had moved into permanent housing would, in turn, be occupied by 200 of the 450 incoming operations households. Accordingly, the remaining 250 operations households would represent the incremental permanent housing requirement at the start-up of the operations period: As was the case for the construction phase, 80 percent of the housing unit : requirements are assumed to be in Ridgecrest, and 20 percent in southwestern : Inyo County. Given the aforementioned assumption, 200 additional permanent units would be required in Ridgecrest, representing 4.3 percent of total housing units in that City in 1975. The requirement for southwestern Inyo County would be an additional 50 units, or 3.7 percent of total units in that area in 1977.

Total project-related incremental requirements for permanent housing units for both the construction and operations phases would be 850 units, 680 of which ": would be required in Ridgecrest, and 170 in southwestern Inyo County. These: requirements represent 14.6 percent and 12.7 percent, of total existing units: in those areas. This incremental requirement would be spread over several years, but would still constitute a fairly sizable impact on the local housing: market. The demand (and price) for existing housing would increase; the need. (and the market) for new permanent housing units also would increase. 


\subsubsection{INFRASTRUCTURE}

The following discussion evaluates the impacts of construction and operationsrelated population increases on the local infrastructure (e.g. police and fire protection, schools, hospitals, waste disposal systems) in the socioeconomic study region. As described above, approximately 2,000 construction workers are expected to occupy onsite temporary housing; 1,500 direct and indirect construction phase employees and dependents will enter the Ridgecrest area, and about 400 employees and families will locate in southern Inyo County. A total peak population inmigration of roughly 3,900 persons is expected to accompany construction of the GRS facility. A permanent population increase of 2,300 persons, 1,850 in the Ridgecrest area and 450 in southern Inyo County, will result from GRS operations and associated indirect employment.

In summary, as will be seen below, GRS infrastructure impacts would be relatively moderate. Project-related population growth would require some additional local police and fire protection capabilities, and would hasten the need for: importation of additional freshwater supplies into the area, upgrading of wastewater facilities/systems in several local communities, and developing new local solid waste disposal sites.

\subsubsection{Police Protection}

Construction phase population increases projected for the Ridgecrest area could require the addition of one police officer in the City's police department, and one officer in the Kern County Sheriff's Department, plus appropriate equipment and vehicle support. Staff increases would be related to overall long-term population growth patterns in the Ridgecrest area and would be dependent on budgetary considerations. No additional police officers will be required in Lone Pine or 01 ancha as a result of migration of GRS constructionrelated workers and their families into the southern Inyo County area. The presence of approximately 2,000 construction workers in an onsite construction camp is likely to create an increase in traffic accidents and offenses related to alcohol consumption in Ridgecrest and Lone Pine; however, no increases in police staff would be likely to result from the temporarily increased act Ivity.

A permanent population increase of approximately 1,850 in the Ridgecrest area and 450 in southern Inyo County would reinforce construction phase impacts, providing additional rationale for the addition of one officer in both the City's police department and the local Kern County Sheriff's station. Inyo County Sheriff's Department staff changes would be related to area growth patterns; GRS development alone would not provide a reason for the addition of staff.

\subsubsection{Fire Protection}

A small increase in the number of calls for fire protection services as a result of construction phase population increases will affect the Ridgecrest, Inyokern, 0lancha, and Lone Pine fire stations; however, no increase in personnel or equipment would be required for this temporary population. 
Operational population increases would contribute to the need for expanding the Ridgecrest and/or Inyokern and 0lancha fire stations by one fire fighter each, plus appropriate equipment, depending on overall population trends and local budgetary policy in these areas.

\subsubsection{Electrical Utility}

To the extent that construction and operations-related employees will be located in existing communities or areas currently provided with electrical transmission facilities, a minor increase in local electrical demand will occur. However, no adverse impacts would be expected. During GRS operations, the 5,000 megawatts of power delivered to the regional grid will, of course, represent a significant addition to the regional grid, and to the extent that local communities are served by the regional system(s), a net benefit would occur.

\subsubsection{Freshwater Supply}

Water consumption during the two-year period required for GRS construction is estimated at 910 to 1,900 thousand cubic meters for concrete production, and 75 thousand to 11 million cubic meters for dust suppression. Water of adequate quality can be obtained from Rose Valley, although some temporary overdrafting of groundwater (or displacement of current agricultural use) would be required. Per capita water consumption is estimated at 0.6 cubic meters per day for workers and their families; a total of approximately 840 thousand cubic meters per year would be consumed by inmigrant workers and their families inhabiting the Ridgecrest/Southern Inyo County/construction camp areas. During operation of the GRS, water consumption by all projectrelated inmigrants is expected to be approximately 500,000 cubic meters per year.

Present conditions indicate that an adequate supply of water to serve the needs of GRS-related population growth will be available in the Indian Wells Valley (City of Ridgecrest), although drawdown of groundwater. supplies in the Valley would be accelerated: the IWV County Water District projects importation of water by the year 2020. Water supplies in the Southern Inyo County areas of: 0lancha, where private wells would be required; Cartago, which has a small community water system; and Lone Pine, which has a water district and is supplied water by the City of Los Angeles Department of Water and Power, would be adequate for the small incremental population growth resulting from the project.

\subsubsection{Sewage/Wastewater Treatment}

Portable sanitary facilities, possibly chemical systems that require no water may be used at the GRS site during construction. Alternatively, a portable wastewater treatment facility could be brought in, with primary treatment being followed by drying and then shipping the remaining sludge to a location where further treatment and ultimate disposal could be achieved. Per capita sewage generation is estimated at 0.38 cubic meters per day. A total of approximately 1,200 cubic meters per day would be generated by inmigrant workers and their families inhabiting the Ridgecrest/Southern Inyo County/ construction camp areas. During operation of the GRS, inmigrant worker and 
family sewage generation will be nearly 900 cubic meters per day. Present capacity of the facilities of the Ridgecrest and Inyokern sanitation districts would accommodate the increase in sewage generated by approximately 1,850 new area residents. Existing Cartago and Lone Pine sewer systems would have to be brought up to standard to accommodate any new residents.

\subsubsection{Sol id Waste Disposal}

Solid waste generation during GRS construction is estimated at 1,800 tonnes per day for rectenna field site prepration, 4.7 tonnes per day for rectenna panel manufacture and installation, and $130 \mathrm{~kg}$ per day for administration and engineering. Per capita solid waste generation is estimated at $2.5 \mathrm{~kg}$ per day. A total of approximately $8,000 \mathrm{~kg}$ per day would be generated by inmigrant workers and their families inhabiting the Ridgecrest/Southern Inyo County/construction camp areas. Additional solid waste will also be generated by workers drawn from local labor and those workers commuting from the Antelope Valley. During operation of the GRS, inmigrant worker and family solid waste generation will be approximately $5,800 \mathrm{kq}$ per day. All construction and operations phase solid waste could be accepted at a Class II facility, and inert construction debris could be taken to a Class II-? or Class III site. The Class II-2 facilities in Ridgecrest and Lone Pine could accommodate construction debris, office-type paper waste, and domestic rubbish. However, the volume of GRS solid waste would significantly reduce the projected remaining useful life of the local landfills and thus hasten the local requirement to develop new facilities. Shredding or mulching of GRS construction phase vegetative wastes also could be considered, which conceivably could result in a salable product.

\subsubsection{Health/Mental Health Systems}

The additional construction and operational-phase population would increase demand for health care and related services, including emergency and outpatient treatment at the Southern Inyo Hospital in Lone Pine and the Ridgecrest Community Hospital, as well as calls for physicians' services. The proposed development may stimulate additional physicians to move into the area. Bed capacity is not fully utilized at the Ridgecrest Community Hospital at present; greater impact might occur at the Southern Inyo Hospital, where facilities are presently utilized to capacity.

\subsubsection{Educational Systems}

Approximately 20 percent of the long-term construction phase inmigrant population (200 direct and 400 indirect workers and their families living in permanent housing) would probably be children of school age; therefore, approximately 260 additional students would enter the Sierra Sands Unified School District (serving the Ridgecrest/Inyokern/Brown Road area) and 60 additional students would enter the Lone Pine Unified School District (serving southwest Inyo County). These numbers would increase to 370 and 90 , respectively, when operation of the GRS begins. Additional students could constitute a beneficial impact on the Lonc Pine Unified School District, where enrullirills have been declining in recent years (McCollum, 1979). The Sierra Sands Unified School Distict is presently at capacity; however, enrollment has been declining there also. A significant population increase could affect the District's plans for any expansion. Some additional enrollment could be expected at Cerro Coso Community College in Ridgecrest. 
With increased population, some undetermined increase in the number of visitors to nearby National Parks, Forests, and Monuments is expected; the total number of visitors resulting from the project would be insignificant in comparison to existing visitor loads. Permanent population increases in the Ridgecrest area would increae the existing need for development of urban parks. Impacts on recreation are also discussed under Land Use.

\subsubsection{TRAFFIC AND TRANSPORTATION SYSTEMS}

Access to the project site would be along U.S. Highway 395 (assumed for this study to be relocated 16 kilometers to the east of its present route through Rose Valley) and a new access road leading eastward from the highway (see Figure 3.11-2). Route 395 is a four-lane, divided highway between Pearsonville and Dunmovin, with a capacity of 4,800 vehicles/hour (vph). North and south of this four-lane segment it has two lanes and a capacity of 2,400 vph. In 1978, it carried an average of 4,400 vehicles per day, which is well below capacity. Construction phase impacts of the proposed.project would consist, for the most part, of increases in peak hour and average daily automobile and truck traffic al ong U.S. Highway 395 between Ridgecrest and Lone Pine. Operations impacts would include increased traffic on Route 395, as well as a potential increase in general traffic within the City of Ridgecrest. Figure 4.9-1 presents maximum project-generated vehicles per day along Highway 395, both north and south of the proposed project access road.

\subsubsection{Construction}

Project-related traffic to and from the project site during the peak traffic period of project development (Months 9-12), could amount to approximately 3,100 vehicles per day along Route 395. Such an increase would represent 70.5 percent of that highway's average daily traffic in 1978. Most of these trips (about 2,700) would approach the site access road from the south for points of origin such as Ridgecrest, Inyokern, Antelope Valley, and the Los Angeles Metropolitan Area. Approximately 1,300 of the 2,700 daily trips originating from this direction would be made by heavy trucks delivering project construction materials. Project-generated trafic approaching from the north would total approximately 400 vehicles per day during the peak construction period, 140 of which would be truck trips for materials delivery.

The construction period peak hour for traffic generation is assumed to be 2:30 p.m., the assumed changeover from day to night shifts for construction workers. In addition to the arrival and departure of commuting construction workers, the hourly average of construction materials truck arrivals and departures would occur during the peak hour. Project-generated peak hour traffic would total approximately 1,460 vph along Route 395 south of the project site, approximately $260 \mathrm{vph}$ along Route 395 north of the project site, and 1,720 vph on the project access road. The increase along the highway south of the project site would represent a significant increase over current usage, however, the 2,400 vehicle hourly capacity of the two-lane segment south of Pearsonville would not be exceeded by the project-generated addition of 1,460 vehicles. Conditions on the highway segment north of the project site, also with a capacity of 2,400 vehicles per hour, would not be affected 


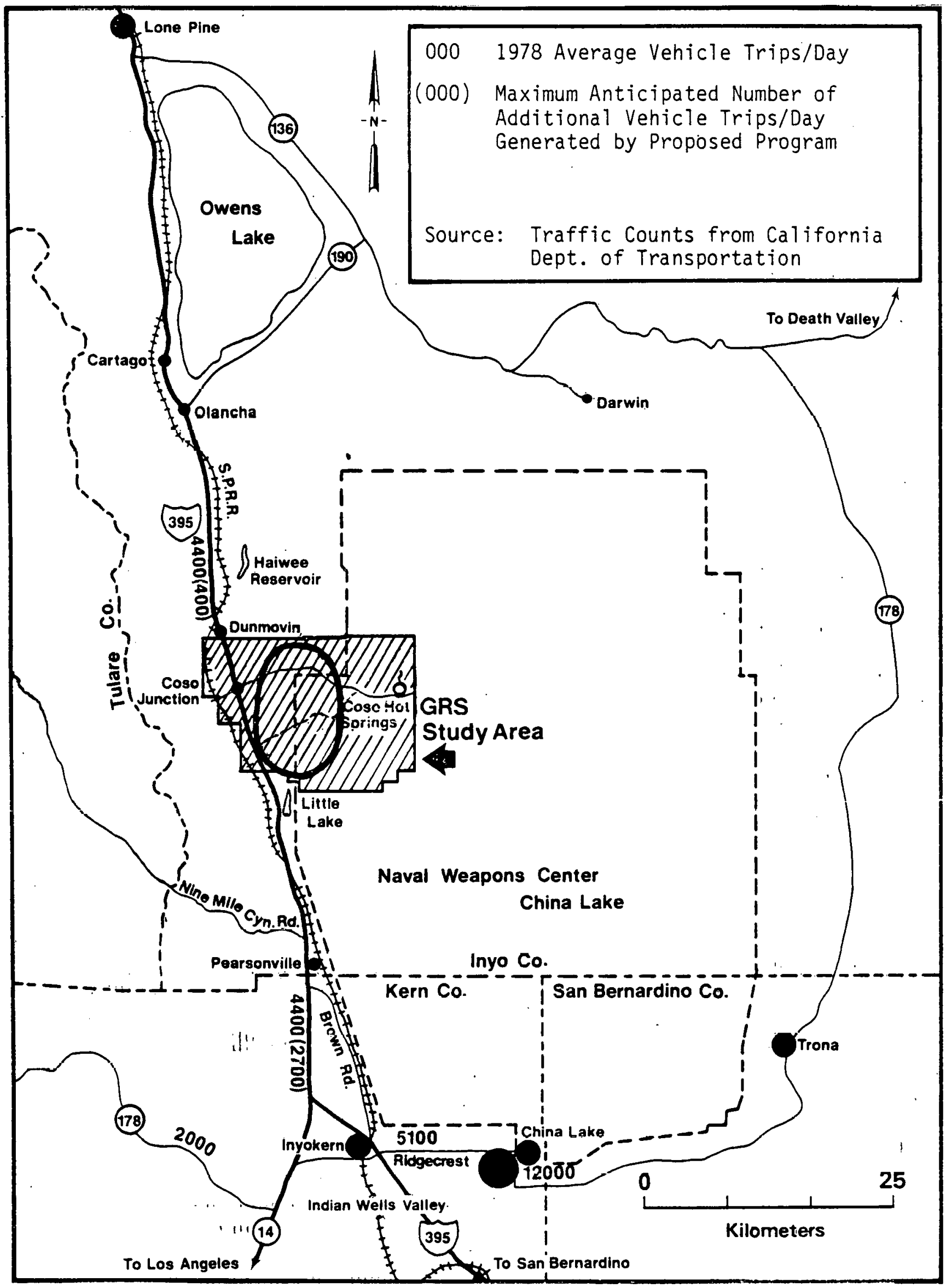

Figure 4.9-1. 1978 ANNUAL AVERAGE DAILY TRAFFIC AND PROJECT-RELATED TRAFFIC IMPACTS ON MAJOR ROADS WITHIN STUDY AREA 
adversely during peak hours by an increase of 260 vehicles. Of the 1,460 vehicles added to existing highway traffic south of the site, about 50 would be heavy trucks; of the 260 added to the segment north of the site, less than ten would be trucks.

Little or no congestion along the four-lane section of Highway 395 is anticipated, with the possible exception of the junction of the project site access road, where slowing and turning of heavy trucks (and recreational vehicles being used by construction workers as their temporary housing) could pose a traffic hazard. The latter effect could be mitigated through construction of special turn lanes. In the two-lane segment below Pearsonville, slow-moving trucks carrying materials or heavy equipment from the southern California area to the site in conjunction with the peak hour traffic flow may lead to some slowing along this section of Highway 395. The impacts described above would be amplified during the usual periods of heavy tourist and recreational traffic on Highway 395, including Fridays, Mondays and holidays, especially during the summer months.

The above analysis is based on the following major assumptions:

- all construction and operations workers residing in permanent housing in Inyo County would commute to the project site along Route 395 from the north;

- all daily trips by Antelope Valley workers would carry 2.0 workers per vehicle;

- all other worker commuter trips to the project site would carry 1.2 workers per vehicle;

- offsite resident workers in transient housing residing in Inyo County would be divided equally between arrivals from the north and south;

- one aggregate plant is assumed to be located north of the project site, representing 10 percent of materials-related traffic to and from the project access road. The remaining 90 percent of materialsrelated traffic to and from the site would thus arrive from the south along Route 395;

- of total.materials, deliveries, 30 percent of total volume was assumed to be delivered by trucks ( 720 round trips per day or 30 per hour);

- miscellaneous project-generated traffic was assumed to be one percent of total trips during the construction period, and 5 percent of total trips during operations; neither of these sets of miscellaneous traffic was assumed to occur during peak traffic hours;

\subsubsection{Operations}

The impacts of project operations would consist of an increase in traffic on Highway 395 due to daily round trips of the three shifts of operations employees (112, 112 and 88 respectively); as well as miscellaneous trips to and from the site, including operational equipment and materials shipments, trips by 'government agency personnel and others, and visits by sightseers. 
The three operations shifts would generate a total of about 530 vpd, while miscellaneous traffic is estimated to be 25 vpd. Shifts one and two would each generate about 180 vpd; 140 vpd travelling along Route 395 south of the project site, and 40 spd approaching the site from Route 395 north of the GRS site. Shift three would generate 150 vpd, 120 vpd approaching the site from the south along Route 395, and 30 vpd utilizing the highway north of the project site. Miscellaneous traffic to the site is estimated to be $25 \mathrm{vpd}, 20$ of which would approach the site from the south, and $5 \mathrm{vpd}$ from the north.

The project-generated increase in total daily vehicle traffic on Route 395 (530 vpd) would represent 12.0 percent of that highway's average daily vehicle traffic in 1978. Peak hour impacts would occur in the late afternoon, with changeover to the evening shift, assumed to be 3:00 - 4:00 p.m. Total vehicles per hour (vph) generated by the change of shifts would total 178. Miscellaneous traffic generated by the project would not be expected to occur during the change of shifts. The 180 vph generated by the project would represent only 7.4 percent of the 2,400 vph capacity of the highway, which currently is utilized at a small fraction of total capacity. Therefore, congestion is not expected to be a problem.

\subsubsection{ECONOMICS}

\subsubsection{Introduction}

GRS development will have significant effects on the economy of the study area. New jobs will be created; local businesses will receive the stimulus of worker payroll spending and project materials purchases; local governments will receive additional sales and property tax revenues, and at the same time will incur additional costs to provide the needed public services for an expanded population base. Economic impacts will differ between GRS construction and GRS operations.

In summary, as will be seen in the following sections, the following economic effects are expected. During GRS construction an average of 3,000 new jobs will be created over two years; an increase in local business activity of about $\$ 270$ million (mostly for construction materials such as cement, sand and aggregate) is expected; and local government revenues will increase by roughly $\$ 850,000$. During GRS operations, 800 new jobs will be created locally; local business activity will increase by about $\$ 10$ million per year; local jurisdictions would incur about $\$ 160,000$ /year in increased public service costs (excluding school district operating costs which are funded mostly by outside sources) and would receive about $\$ 395,000 /$ year in increased revenues. (Some of the increased public service costs actually will begin at some point during the two-year likS construction phase.)

\subsubsection{Employment}

GRS construction would directly produce about 10,000,000 man-hours of work over a two-year period. Average construction manpower requirements would be 2,500, while peak requirements (Months 16-24) are estimated to be 3,200. Local hires are expected to account for 20 percent $(500)$ of average construction employment. Another 10 per cent (250) are expected to be filled by current residents of the Antelope Valley, who would commute daily to the project site (a roundtrip of about $300 \mathrm{kilometers).} \mathrm{The} \mathrm{remaining} \mathrm{1,750} \mathrm{positions} \mathrm{would} \mathrm{be} \mathrm{filled} \mathrm{by}$ workers from outside the project's region of influence (assumed to come mainly from the greater Los Angeles area). 
The indirect employment effects of project construction would consist of increased employment in the Ridgecrest area and southwestern Inyo County generated, for the most part, by construction materials purchases and construction work force payroll spending. Indirect construction employment impacts were determined through use of an employment multiplier of 1.2. That figure represents 20 indirect jobs created for every 100 direct jobs created during the project's construction phase. Table 4.9-3 presents project-related employment increas̀es by location.

The total employment impacts of project construction include the creation of 3,000 direct and indirect jobs over the two year period, 2,600 in southwestern Inyo County, and the remaining 400 in the Ridgecrest-Inyokern area of Kern County.

Long-term employment impacts of project operations would include 450 direct project operations positions, all of which are expected to be filled by imported labor. Project operations-induced indirect employment is estimated to about 350 , based on an operations multiplier of 1.8. Of approximately 800 newly-created permanent positions (450 direct and 350 indirect), nearly 300 would be located in the Ridgecrest-Inyokern area of Kern County, while approximately 500 would be located in southwestern Inyo County (see Table 4.9-3). The 500 jobs created in Inyo County would represent a 5.7 increase above the 1977 county total employment of 9,225 . The nearly 300 jobs created in Kern County would represent a 0.2 percent increase over that county's 163,000 total employment in 1977.

\subsubsection{Business Activity}

Wholesale and retail trade would increase significantly in the RidgecrestInyokern area and in southwestern Inyo County as a result of both project construction activities and project operations.

Project construction would require expenditures of $\$ 1.6$ billion for construction materials and equipment; 15 percent of which, or $\$ 240 \mathrm{milli}$, would be spent locally. An undetermined, but probably substantial portion of the remaining materials would be purchased elsewhere in California, with the incremental business business activity accruing to the jurisdictions at the point of sales.

Retail sales from construction workforce payroll spending would be the other major component of the project's impact on local and regional trade. Total construction phase payroll expenditures (including indirect workers) over the two-year construction period are estimated to be approximately $\$ 32$ million (see Table 4.9-4). This figure is based on payroll rates of $\$ 26,000$ per construction man-year covering a two year period, and $\$ 12,000$ per man-year of indirect labor generated by project construction. The City of Ridgecrest in Kern County would receive $\$ 26$ million of the total payroll expenditures, while southwestern Inyo County would receive the remaining $\$ 6$ million.

Project operations also would generate local and regional purchases of materials and equipment, as well as local payroll expenditures. Total annual purchases of materials and equipment for project operations and maintenance is estimated to be $\$ 13.0 \mathrm{milli}$ on. It was assumed that 15 percent of that total, or approximately $\$ 2.0$ million in purchases would be made locally, $\$ 1.5$ million in Ridgecrest, and $\$ 0.5$ million in southwestern Inyo County. Project operations annual payroll expenditures would total approximately $\$ 8.0$ million (see 
Table 4.9-3 PROJECT EMPLOYMENT IMPACTS

\begin{tabular}{|c|c|c|c|}
\hline - & $\begin{array}{l}\text { Southwestern } \\
\text { Inyo County }\end{array}$ & $\begin{array}{l}\text { Ridgecrest } \\
\text { (Kern County) }\end{array}$ & Total \\
\hline \multicolumn{4}{|l|}{ Construction Phase } \\
\hline $\begin{array}{l}\text { Two-year positions } \\
\text { Short-term positions (average) } \\
\text { Indirect. jobs (long-term) }\end{array}$ & $\begin{array}{r}200 \\
2,300 \\
100\end{array}$ & $\begin{array}{r}0 \\
0 \\
400\end{array}$ & $\begin{array}{r}200 \\
2,300 \\
500\end{array}$ \\
\hline Total (direct and indirect) & 2,600 & 100 & 3,000 \\
\hline \multicolumn{4}{|l|}{ Annual Uperations Impacts } \\
\hline $\begin{array}{l}\text { Project operations } \\
\text { Indirect jobs (continuation of } \\
\text { construction phase } \\
\text { indirect positions) }\end{array}$ & 450 & 300 & 450 \\
\hline Total & 520 & 300 & 800 \\
\hline
\end{tabular}


Table 4.9-4. LOCAL PAYROLL SPENDING DURING CONSTRUCTION (Thousands of Dollars)

\begin{tabular}{lccc}
\hline & Direct & Indirect & Total \\
\hline Payroll & $\$ 104,0001$ & $\$ 9,500^{2}$ & $\$ 113,500$ \\
Disposable Income & & $\$ 7,000$ & $\$ 85,000$ \\
Local Spending 4 & $\$ 27,000$ & $\$ 5,000$ & $\$ 32,000$ \\
Spending in Inyo County & & & $\$ 6,500$ \\
(at 20\%) & & & $\$ 25,500$ \\
Spending in Ridgecrest & & & \\
Area (at $80 \%$ ) & & & \\
\hline
\end{tabular}

1. Direct employee payroll of $\$ 26,000$ per man-year for two years.

2. Indirect employer payroll of $\$ 12,000$ per man-year for two years.

3. Disposable income is 75 percent of payroll (U.S. Burea of Labor Statistics).

4. Two-year construction employees (200) and indirect employees (400) spend $70 \%$ of disposable income locally; weekly commuters $(1,750)$ spend $35 \%$. of disposable income locally; dialy commuters (250) spend $5 \%$ of disposable income locally. 
Table 4:9-5). This figure is based on a rate of $\$ 24,000$ per operations employee, and $\$ 12,000$ per employee in indirect jobs generated by project operations. The Ridgecrest area would receive approximately. $\$ 6.5$ million of the total payroll expenditures, while southwestern Inyo County would receive the remaining $\$ 1.5 \mathrm{million}$.

\subsubsection{Public Fiscal Effects}

The construction and operation of an SPS GRS in the Rose Valley/Coso area would result in an increase in both revenues received and expenditures paid out by local jurisdictions. The principal revenue sources for local jurisdictions would be sales and use tax subventions resulting from materials purchases and employee expenditures, and property tax revenues from commercial expansion and additional housing units for inmigrants. The additional public expenditures take the form of costs for new public infrastructure or equipment and additional personnel.

Construction of the proposed GRS would result in $\$ 1.6$ billion of expenditures for construction materials. It was assumed, for purposes of this analysis, that the proposed project would be 100 percent publicly nwned and operated; therefore the purchases of construction materials would be non-taxable. Miscel laneous purchases made by construction contractors in the local area are assumed to be approximately one percent of the project's non-labor costs. The project contractor was assumed to be located in Ridgecrest; thus the City of Ridgecrest and Kern County would receive tax revenues from these miscellaneous purchases. Kern County would receive about $\$ 40,000$ in sales tax subventions from construction materials purchases while the City of Ridgecrest would receive about $\$ 160,000$. Fuel used at the construction site would also be subject to sales taxation. The $\$ 42$ million of construction fuel deliveries to the project site would yield $\$ 525,000$ in sales tax subventions.

GRS construction activities would generate approximately $\$ 32$ million in payroll expenditures over a two-year period; of which approximately $\$ 17$ million would be taxable. Sales tax revenues attributable to those sales would total about $\$ 1.0$ million, $\$ 200,000$ of which would go to local governments, and $\$ 800,000$ to the State of California. Table 4.9-6 presents the distribution of sales tax revenues from project construction payroll expenditures to local governments. Over the two-year period, Inyo County would receive about $\$ 570,000$ in sales tax subventions, Kern County $\$ 60,000$, and the City of Ridgecrest, $\$ 220,000$. Sales tax subventions in Inyo County totaled approximately $\$ 500,000$ in Fiscal Year 1977-78; thus project constructiongenerated sales tax revenues over the two-year period would be approximately 114 percent of the 1977-78 total. Sales and use tax subventions to the City of Ridgecrest and Kern County totalled $\$ 0.7$ million and $\$ 10.7$ million respectively, in Fiscal Year 1977-78. Project construction-generated sales and use tax subventions over the two-year period would represent 31 percent and 0.5 percent respectively of Ridgecrest's and Kern County's sales and use tax subventions in 1977-78.

Project operations also would generate sales tax revenues. All of these revenues would be the result of payroll expenditures of project operations employees and payroll expenditures of project-induced employment. Materials and equipment purchases for project operations would not be taxable under the assumption that the project would be publicly owned and operated. 
Table 4.9-5. LOCAL PAYROLL SPENDING DUURING OPERATIONS

(Thousands of Dóllars)

\begin{tabular}{lccc}
\hline & Direct & Indirect & Total \\
\hline Payrol1 & $\$ 11,000^{1}$ & $\$ 4,000^{2}$ & $\$ 15,000$ \\
Disposable income 3 & $\$ 8,000$ & $\$ 3,000$ & $\$ 11,000$ \\
Local Spending4 & $\$ 5,500$ & $\$ 2,500$ & $\$ 8,000$ \\
$\begin{array}{l}\text { Spending in Inyo- County } \\
\text { (at 20\%) }\end{array}$ & & & $\$ 1,500$ \\
$\begin{array}{l}\text { Spending in Ridgecrest } \\
\text { Area (at 80\%) }\end{array}$ & & & $\$ 6,000$ \\
\hline
\end{tabular}

1. Direct employee payroll at $\$ 24,000$ per man-year.

2. Indirect employee payroll at $\$ 12,000$ per man-year.

3. Disposable income is $75 \%$ of payroll (U.S. Bureau of Labor Statistics).

4. Direct and indirect employees spend $70 \%$ of disposable income 1ocally. 
Table 4.9-6. PUBLIC REVENUES - TEMPORARY

$\because$ (Thousands of Dollars)

\begin{tabular}{|c|c|c|c|}
\hline$\cdot$ & Inyo County & $\begin{array}{l}\text { Ridgecrest } \\
\text { (Kern County) }\end{array}$ & Total \\
\hline Local Payroll Spendingl & $\$ 6,400$ & $\$ 25,600$ & $\$ 32,000$ \\
\hline Taxable Payroll Spending 2 & 3,500 & 13,900 & 17,400 \\
\hline Construction Overhead ${ }^{3}$ & 0 & 8,000 & 8,000 \\
\hline Fuel Purchascs 4 & 42,000 & 0 & $4 \hat{\imath}, 000$ \\
\hline Táxable Sales & $\$ 45,500$ & $\$ 21,900$ & $\$ 67,400$ \\
\hline $\begin{array}{l}\text { Local Sales Tax } \\
\text { Subventions }\end{array}$ & $\$ 570$ & $\$ 280$ & $\$ 850$ \\
\hline
\end{tabular}

1. From Table 4.11-4.

2. Assumes $40 \%$ of 1 ocal expenditures by two-year construction workers and indirect workers are taxable, $60 \%$ of local expenditures by weekly commuters are taxable, $100 \%$ of local expenditures by daily commuters are taxable.

3. Assumes $50 \%$ of construction overhead spent locally ( $\$ 16$ million) is taxable.

4. Fuel purchases are taxable at the construction storage tank located in Inyo County. Assumes a 1977 fuel price of $\$ 0.50$ per gallon.

5. Inyo County receives $1.25 \%$ of taxable sales; Ridgecrest receives $1 \%$ of taxable sales $(\$ 219,000)$; Kern County receives $0.25 \%$ of taxable sales $(\$ 55,000)$. 
Project operations would generate approximately $\$ 8.0$ million in local payroll expenditures annually, of which $\$ 3.2$ million would be taxable (Table 4.9-7). Inyo County would receive $\$ 8,000$ per year in sales tax subventions, which would represent 1.6 percent of $\mathrm{Fiscal}$ Year 1977-78 sales and use tax revenues. Kern County would receive $\$ 6,000$, or 0.06 percent of $1977-78$ revenues; ' and Ridgecrest would receive $\$ 25,000$, or 3.6 percent of Fiscal Year 1977-78 sales tax revenues.

\subsection{Property Tax Revenues}

The project, itself, would not produce property tax revenues, under the assumption that it would be publicly owned and operated. Project-related residential and commercial development would increase assessed valuation, and thus the property tax bases of Inyo County, Kern County, and the City of Ridgecrest. An estimate of the project's impact on the property tax revenues of project area governmental jurisdictions was made by the following method:

- develop an existing ratio of assessed valuation to population within those jurisdictions;

- multiply the above results by one percent to determine the per capita limit of taxation; and

- multiply the per capita limit of taxation by the projected population increase in each jurisdiction.

Table 4.9-8 presents estimated project-generated property tax revenues by jurisdiction. Given the aforementioned assumptions, and applying the assessed valuation/population ratio during Fiscal Year 1.977-78 within each jurisdiction, project-generated annual property tax revenues would be approximately $\$ 130,000$ for Inyo County, and $\$ 225,000$ for Ridgecrest/Kern County.

\subsection{Public Service Costs}

Although GRS siting would involve a direct increase in the marginal workloads of public employees (e.g. general government, fire, and police), it is expected that these would be relatively insignificant and would not require any increase in public expenditures. However, the project would likely generate an indirect (population growth-related). need for additional public expenditures.

Population growth-induced public service requirements could include the addition of one police officer each to the City of Ridgecrest Police Department, and the Kern County Sheriff's Department. It is expected that Inyo County would not require additional personnel. No additional facilities or major equipment would be required. The incremental cost of the additional personnel would be approximately $\$ 40,000$ per year for each of the two jurisdictions.

Impacts on fire departments could include the addition of one firefighter each in the Ridgecrest Fire Department, and the Inyo County Fire Department station at 01 ancha. The cost of such additions would be approximately $\$ 40,000$ per year for each jurisdiction. 
Table 4.9-7. PUBLIC REVENUES AND COSTS - PERMANENT

(Thousands of Dollars)

\begin{tabular}{|c|c|c|c|}
\hline & Inyo County & $\begin{array}{l}\text { Ridgecrest } \\
\text { (Kern County) }\end{array}$ & Total \\
\hline Local Payroll Spending1 & $\$ 1,600$ & $\$ 6,300$ & $\$ 7,900$ \\
\hline Taxable Payroll Spending ${ }^{2}$ & 600 & 2,500 & 3,100 \\
\hline Local Sales Tax Subventions 3 & 10 & 30 & 40 \\
\hline Local Property Tax Revenues 4 & 130 & 225 & 355 \\
\hline Total Local Public Revenues & 140 & $255^{5}$ & 395 \\
\hline Lucal Publ ic Costs 6 & 40 & $\therefore 1207$ & 160 \\
\hline Net Public Fiscal Effects & +100 & +135 & +235 \\
\hline
\end{tabular}

1. From Table 4.9-5.

2. Assumes $40 \%$ of spending is taxable.

3. Inyo County receives $1.25 \%$ of taxable sales; Ridgecrest receives $1.0 \%$ of taxable sales $(\$ 25,000)$; Kern County receives $0.25 \%$ of taxable sales $(\$ 5, n \cap n)$.

4. From Table 4.9-8.

5. Includes sales tax subventions received by Kern County.

6. Additional police and fire protection expenses; excludes additional operating costs for local school districts, a significant portion of which would be funded by state governments.

7. Includes both City of Ridgecrest $(\$ 80,000)$ and Kern County $(\$ 40,000)$. 
Table 4.9-8. PROJECT-GENERATED PROPERTY TAX REVENUES

\begin{tabular}{|c|c|c|}
\hline . & Inyo County & $\begin{array}{l}\text { City of Ridgecrest } \\
\text { (Kern County) }\end{array}$ \\
\hline Assessed Valuation 1977-1978 & $\$ 129,580,494$ & $\$ 45,059,295$ \\
\hline Market Value & $\$ 518,300,000$ & $\$ 180,200,000$ \\
\hline Population & 17,981 & 14,610 \\
\hline Market Value per Capita & $\$ 28,800$ & $\$ 12,300$ \\
\hline 1\% Tax Limit per Capita & $\$ 288$ & $\$ 123$ \\
\hline Population Increase & 460 & 1,840 \\
\hline Additional Property Tax revenues & $\$ 130,000$ & $\$ 225,000$ \\
\hline
\end{tabular}


No significant infrastructure (or capital) 'cost would result from projectgenerated population growth in terms of provision of electricity, natural gas, water utility services, solid waste collection services, and health services. The costs to each agency or company of servicing additional populations is expected to be balanced by user charges, fees and related revenues.

The project-generated inmigration of families with school-aged children would not require capital improvements to the project area's school systems because student enrollments are safely below capacity. Schools in Inyo County are sufficiently below capacity at present so that no additional costs would be expected as a result of adding the projected 90 students. The addition of 370 students to the Sierra Sands School District (Ridgecrest) would add approximately $\$ 900,000$ per year to the District's operational costs (based on $\$ 3,100$ per average daily attendance (A.D.A.) and 0.85 A.D.A. per enrolled student).

In summary, as shown in Table 4.9-7, public revenues would exceed costs by roughly $\$ 100,000$ per year in Inyo County and $\$ 135,000$ in Kern County (including the (ity of Ridgecrest) during project operations. This excludes school district operational costs, a sizable proportion of which would be funded by the state government.

\subsubsection{Private Ownership}

If the GRS were owned and operated by a private utility or utility consortium, then facility construction and operation would result in a significant increase in public revenues to Inyo and Kern Counties. Private ownership of the GRS would mean that all materials purchased for construction of the plant would be subject to sales tax and the GRS itself would be subject to property taxation. In terms of the local study area, the purchase of $\$ 240$ million of local materials (primarily cement and aggregate) would result in over $\$ 3.0$ million in additional sales tax subventions being returned to the local counties and/or cities. This amount would represent an increase of 350 percent over the nearly $\$ 850,000$ in sales tax subventions presented in Table 4.9-6. Additional sales tax subventions of approximately $\$ 16$ million (based on other materials purchases of $\$ 1.3$ billion) could be received by other cities and counties of California. For California purchases, the subventions would be received by the jurisdictions at the point of sales. Under California law, purchases made outside California are taxable at the point of delivery within California, in this case, Inyo County. Thus out-of-state purchases would substantially increase sales tax subvention revenues to Inyo County.

Potential property tax effects on Inyo County from private ownership of the GRS are difficult to calculate. The California State Board of Equalization calculates the assessed value of a public utility on a statewide basis. Included in the calculation are the rate base, corporate stock values and debt, and facility replacement costs. Once an assessed value has been calculated for the utility as a whole, the assessed value is apportioned to counties based on the historical cost less depreciation of facilities located in each county. Attempts to perform such a calculation are beyond the scope of this report, although a rough order of magnitude estimate can be made by applying the one percent property tax rate to the GRS facility. The one percent tax rate applied to the $\$ 1.7$ billion GRS would yield $\$ 17$ million in property taxes the first year. Tax revenues would decline by approximately three percent per year in each succeeding year as depreciation is taken into account. 


\subsubsection{Boomt own Effects}

Large construction projects in rural areas often create undesirable side effects in the rural communities as the population growth and increased demand for infrastructure and services outstrip the local capacity to meet these needs. Two common problems relate to the lag between expenditures for public infrastructure and the receipt of project-related public revenues and the layoff of local construction workers after project construction is completed. Other important boomtown effects unrelated to the above problems include rapid increases in prices for housing and other goods and services (which particularly affect the elderly and the poor), a loss of "rural atmosphere," and increased social conflict between outsiders (e.g. construction workers) and local residents.

The inmigration of construction workers and their families requires, in many cases (although less so in Rose Valley/Coso than in even less populous areas), the construction of additional public infrastructure (e.g. schools, hospitals, police and fire) and the employment of additional public employees. However, the facilities which stimulate this growth do not begin to provide revenues to the local community until after the facility has been built and begins operating. For SPS the problem would be further complicated if the GRS were publicly owned, since the GRS would not be subject to property taxation and little property tax revenue would accrue to the local area. These problems can be mitigated in part by careful early planning, prepayment of future taxes, Federal Energy Impact assistance, etc. Within the Rose Valley/Coso. area, the cost/revenue timing problem would be less than in many areas of. the rural Southwest because of proximity of the Los Angeles metropolitan area. The proximity to Los Angeles would reduce GRS-related local growth because a greater percentage of construction workers will leave their families at home and commute home on weekends than would be case in other areas of the Southwest.

Another boomtown problem relates to the "bust" at the end of the construction phase. The layoff of construction workers at the beginning of the operations phase and the eventual layoff of excess indirect workers (500 during construction versus 350 during operations) would cause a significant increase in local area unemployment. This can be a difficult problem to mitigate, since there may not be sufficient time to train unemployed local workers for employment at the GRS facility or the required education/skill level may not be available locally.

\subsubsection{MITIGATION}

GRS socioeconomic effects (and hence mitigation needs) at Rose Valley/Coso would be greater during facility construction than facility operation because of the size of the workforce $(3,200$ peak during construction vs. 450 during operations), and associated local population growth. The primary mitigation for the impacts of rapid construction phase population growth and impacts on local housing, government services, etc. is the provision onsite of temporary housing facilities for construction phase personnel. It has been assumed throughout our socioeconomic analysis that temporary housing to accommodate a peak of 2,000 persons onsite will be provided as part of GRS development. Locally available workers and workers within daily commuting range, together with the onsite housing assumed, would allow GRS development 
to occur in Rose Valley/Coso without the severe "boomtown" effects that have occurred recently in many rural areas of the western United States. SPS impacts on Rose Valley/Coso socioeconomic conditions would be relatively minor, under the assumptions used in this prototype assessment.

As noted above, careful advance planning, as well as outside financial assistance could be required for GRS siting in areas where the local population base and infrastructure are smaller and less developed than the Rose Valley/Coso area. This would help ensure that the infrastructure needed is in place when the impacts occur.

A further mitigation for socioeconomic impacts on Rose Valley/Coso (or any other GRS siting area) relates to the 25-month (including one month for startup and testing) schedule for GRS construction. If this schedule were extended, then the size of the peak construction phase workforce would be correspondingly smaller, which would reduce the strain on the socioeconomic fabric of the siting area.

Another socioeconomic mitigation measure, although it is more in the nature of compensation for impacts than impact reduction, would relate to GRS ownership. Public ownership would produce relatively small tax revenues for the siting area jurisdictions because public facilities are exempt from property and sales taxation. Private ownership, by contrast, would produce substantial revenues: an estimated $\$ 17$ million in property tax revenues alone for a GRS in California during the first full year of operation. While these revenues would not accrue to the local jurisdictions in time to help them develop needed infrastructure to cope with GRS construction phase population growth, the additional revenues could be considered as compensation for the disruption to the siting area's rural lifestyle and generally for any environmental costs that GRS development would impose on the siting area.

4.10 CULTURAL RESOURCES

\subsection{0 .1 INTRODUCTION}

Construction and operation of the GRS at the Rose Valley/coso site would result in major impacts, mostly adverse, on the cultural (archaeological, and historical) resources of the area. The following section attempts to: define the resources most likely to be impacted, identify the nature and magnitude of impacts, suggest possible impact mitigation measures, and to indicate those adverse impacts which would result in unavoidable and irreparable resource loss.

Calculation of impacts is based on the GRS development-related surface and sub-surface ground disturbances described in Chapter Two of this report (Description of Proposed Action) and summarized in Table 4.8-1. It is assumed that rectenna field site preparation and grading will totally disturb an area of 10,500 hectares of 1 and to an average depth of two meters; on-site support facilities (and possibly an onsite or near-site solid waste disposal site) would disturb an additional roughly 100 hectares. Access roads and rail lines would create 50 hectares of surface disturbance, 30 hectares of which would be disturbed to a depth of one meter. Construction of the perimeter road and fence and the utility supply corridor (e.g. telephone and power lines to the construction site) would disturb approximately 70 hectares 
of land surface. Finally, development of a borrow pit to supply and process construction aggregate and sand would disturb about 200 hectares of land to a depth of 10 meters (however, cultural/archaeological artifacts would be expected only in the top-most five meters).

Discussion of archaeological site location and calculation of quantitative impacts is based on a probabilistic model developed from recent field surveys of the study area; because these surveys covered only about 30 percent of the GRS site and were conducted by random stratified surface sampling methods, it is assumed that the entire site consists of a proportionally uniform surface and sub-surface distribution of artifacts, covering 50 percent and 10 percent respectively of the area to be disturbed by construction and operation of the GRS. All impacts are assumed to occur during the construction phase and to continue throughout the life of the project, few of which would be reversible or subject to restoration on completion of the project.

\subsubsection{SUMMARY OF CULTURAL/HISTORICAL RESOURCES PRESENT}

Because the GRS site lies within a region of unusual archaeological significance, variety, and density, its sensitivity and vulnerability to disturbance is particularly acute. Although not all potential GRS siting areas within the Basin and Range province would be expected to exhibit the potential for severe impact encountered in the Rose Valley/Coso area, similar types and ranges of impacts would be likely. No historical (as opposed to prehistoric) resources of significance have been located within the GRS site, however.

Section 3.12 contains a description of the rich cultural and archaeological resources found within the study area. The degree of sensitivity to disturbance of these resources and their generalized location is shown in Figure 4.10-1. Although less than one-third of the GRS site was surveyed, sample units which would be impacted by the rectenna field and associated facilities show a high degree of sensitivity; more than two-thirds of those units sampled contained significant archaeologic materials, and, overall, an average of 50 percent of the surface area surveyed was covered by various artifacts (mainly lithic scatters, village sites and temporary hunting camps, isolated rock shelters, lithic quarries, and cairns). This represents a remarkable artifactual density over such a large area. Although the average site density was only 1.75 per square kilometer, most sites were discovered to be quite extensive, several covering more than 100 hectares. One area of 330 hectares, located in the southwest portion of the GRS site, contains such a notable density and extent of important archaeologic remains that it has been proposed for nomination to the National Register of Historic Places as the Fossil Falls Archaeological District. Also, a 10-hectare "prayer site," part of the Coso Hot Springs National Register Site, lies within the eastern portion of the GRS buffer zone.

No attempt was made to survey sub-surface artifactural sites or to determine the vertical extent of buried materials. However, based on similar surface densities and known prehistoric occupance sequences within the Great Basin, it is assumed that at least 10 percent of the surface area containing sites or artifacts is underlain by significant sub-surface deposits of stratified archaeologic materials. Given a known occupance history of at least 5,000 years for Rose Valley and a constant rate of geologic material deposition within this alluvial valley, it is assumed that 100 percent of these materials lie within five meters of the ground surface, and 90 percent within the topmost two meters. 


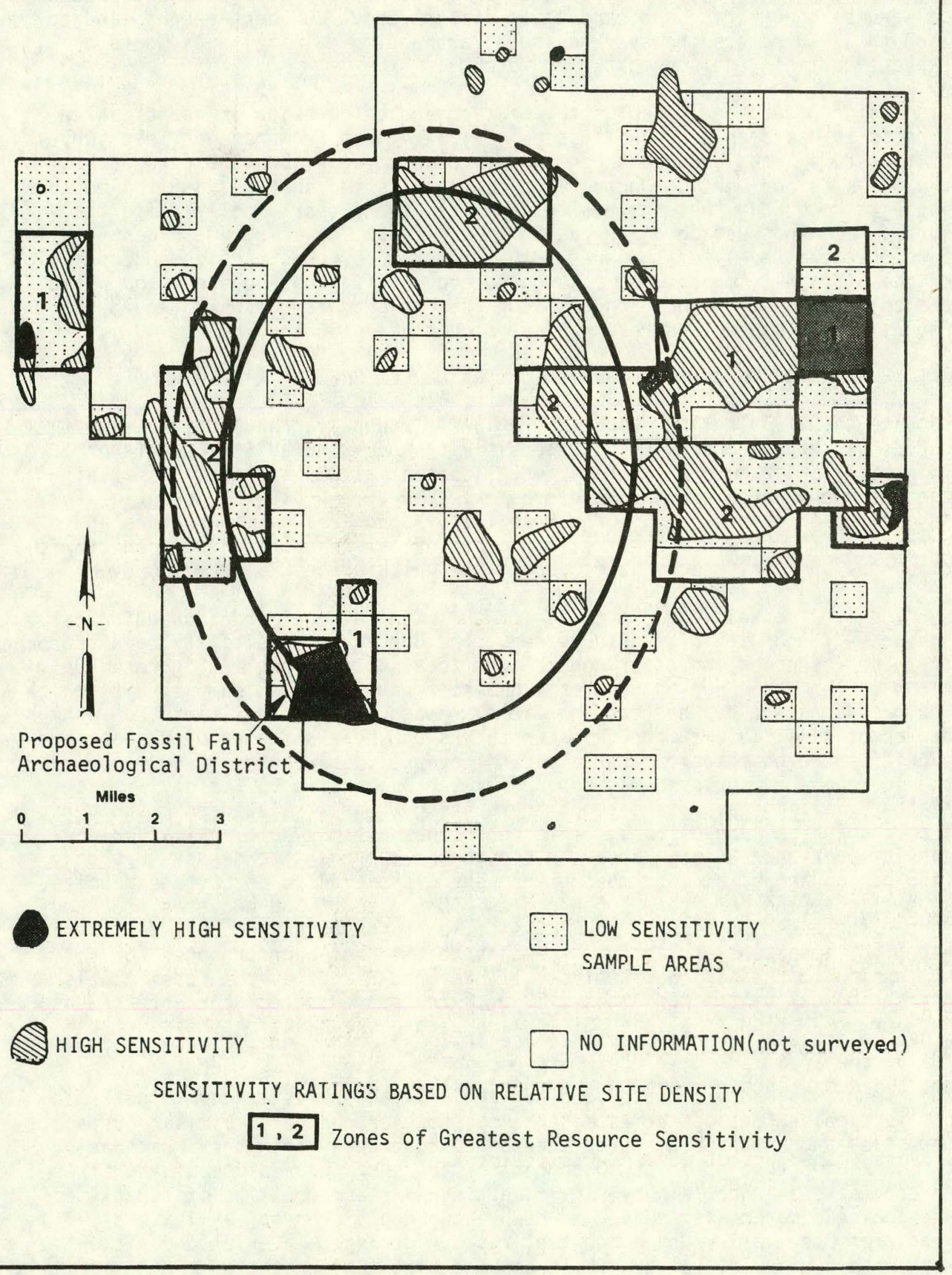

Figure 4.10-1. IMPACTS ON CULTURAL/ARCHAEOLOGICAL RESOURCES 
Impacts caused by GRS development would be of three types: 1) direct impacts resulting from destruction of sites and artifacts by construction activities and subsequent ground disturbance; 2i) indirect impacts caused by increased access to, interest in, and human use of the area during and after construction; and 3) impacts on the cultural values and concerns of Native Americans, for whom the area continues to hold traditional, spiritual, and medicinal significance.

\subsubsection{Ground Disturbance (Direct) Impacts}

Impacts resulting from the disturbance of surface and sub-surface archaeologic materials are summarized in Table 4.10-1. The magnitude and severity of this impact is indicated by the potential for total destruction of surface sites and artifacts covering nearly $55 \mathrm{milli}$ on square meters and sub-surface archaeologic materials occupying at least 11 million cubic meters. Such massive loss of important cultural and archaeologic resources is almost unprecedented; only in projects requiring large-scale inundation of resource lands (e.g.,. the creation of man-made reservoirs like Lake Mead and Lake Powell) would comparable losses be expected.

The most severe impacts are those caused by extensive excavation and ground material movement, since this results in a total loss of resources; grading and rectenna site preparation, along with borrow pit operation, create the most. massive impact, more than $53 \mathrm{million}$ square meters of surface resource destruction and 11 million cubic meters of sub-surface destruction of significant archaeologic materials. All other sources of disturbance/destruction are small by comparison, but significant considering the nature and sensitivity of the resource being impacted.

\subsubsection{Indirect Impacts}

GRS siting also would have significant effects on cultural resources which are not directly the result of facility construction and operation. For example, access to important historical/cultural/archaeological sites within the Coso Mountains (like the Coso Hot Springs National Register Site and the numerous rock art sites nearby) would effectively be prohibited. In one sense, this is an adverse impact, because it denies use and appreciation of such resources by the general public; on the other hand, access denial also greatly reduces the chances of vandalism, "pot-hunting," and resource destruction by visitors to the area. This factor becomes even more significant given the greatly increased population working and living nearby during the construction phase of the project and the expected increase in tourism and general public knowledge of the area as a result of interest in the GRS project. Protection (from curious sightseers and pot-hunters) of onsite cultural resources discovered as a result of construction activities would also be a problem, given the geographic, extent of ground disturbance. and the likelihood of discovery; construction workers themselves would perhaps be tempted to practice "backyard archaeology." 
Table 4.10-1. SIGNIFICANT DISTURBANCES OF GRS SITE CULTURAL RESOURCES

\begin{tabular}{|c|c|c|c|c|c|}
\hline $\begin{array}{l}\text { Cause of } \\
\text { Ground Disturbance }\end{array}$ & $\begin{array}{c}\text { Area } \\
\text { Disturbed } \\
\text { (hectares) }\end{array}$ & $\begin{array}{l}\text { Average Depth } \\
\text { of Disturbance } \\
\text { (neters) }\end{array}$ & $\begin{array}{c}\text { Volume of } \\
\text { Disturbance } \\
\text { (10 } 3^{3} \text { cubic meters) }\end{array}$ & $\begin{array}{l}\text { Assumed } \\
\text { Resource } \\
\text { Surface } \\
{\left[1 j s^{5} \div \text { urbance } 1\right.} \\
\left(11^{3} \text { square meters) }\right.\end{array}$ & $\begin{array}{l}\text { Assumed } \\
\text { Resource } \\
\text { Sub-surface } \\
\text { Disturbance } 2 \\
\text { (103 cubic meters }\end{array}$ \\
\hline Rectenna Field & 10,500 & 2 & 210,000 & 52,500 & 10,500 \\
\hline Borrow Pit & 200 & 10 & 20,000 & 1,000 & 500 \\
\hline Onsite Support Facilities & 84 & 2 & 1,680 & $420^{\circ}$ & 85 \\
\hline Access Road and Rail Spur & 48 & 1 & 320 & 240 & 25 \\
\hline Perimeter Road and Fence & 50 & 0.2 & 100 & 250 & 5 \\
\hline Sol id Waste $D \doteqdot$ sposal Site & 30 & -2 & 600 & 150 & 30 \\
\hline Utility Supply Corridor & 20 & 0.5 & 100 & 100 & 5 \\
\hline TOTALS & 10,930 & -- & 232,800 & 54,660 & 11,150 \\
\hline
\end{tabular}

1. Resources assumed to exist over $50 \%$ of surface area.

2. Sub-surface resources assumed to exist at jepth of 0.1 to 5 meters beneath $10 \%$ of the area containing surface resources. 


\subsubsection{Native American Cultural Values and Concerns}

Because the GRS site lies within an area traditionally used by both historic and prehistoric Indian groups, the potential for impact on Native American. values and concerns is considerable. The 10-hectare "prayer site," within the eastern edge of the buffer zone, is of great symbolic and religious importance to members of the Owens Valley Paiute-Shoshone tribe, and is used by them several times each year; denial or even reduction of access would be of great concern to this group, even if no surface disturbance or other "desecration" were to take place. Further, although no other burial, ceremonial, or spiritual sites have been discovered within the GRS site, most local Indian leaders feel that such cultural resources are present and that their disturbance would offend both contemporary Indians and the spirits of their ancestors. See Section 4.8 (Land Use) for additional discussion of Native American impact concerns and issues.

\subsubsection{MITIGATION}

\subsubsection{Avoidance/Realignment/Re-siting}

Although not germane to this particular study, it is clear that pre-siting study and avoidance of conflict/impact is the preferred method of mitigation, especially considering the strong likelihood of significant impacts resulting from GRS siting in the Great Basin. Planning which incorporates both pre-siting study and avoidance measures is also the cheapest and least time consuming of mitigation methods available to protect cultural/historical resources. For example, it could take approximately three months and 300 to 500 man-hours to prepare a site study and resource preservation plan consisting of a Class I (literature) search, a one percent field sample survey, site mapping, and development of a protection plan for resources expected to be encountered. A determination of the relative value and sensitivity of resources could be made in order to establish preservation/protection priorities (not all resources should or could be saved); similar prioritization could be applied to decisions on which resources can and should be salvaged in advance of construction activities. Obviously certain resources, such as the National Register sites, would be given maximum protection, probably by resiting or altering the site alignment to avoid such sensitive areas altogether. Monitoring programs could also be established to minimize impacts and to deal with those resources unexpectedly encountered during site preparation and construction. Ideally, such use of avoidance/site selection should result in highly effective, efficient resource protection at minimal cost.

\subsubsection{Protection through Design and Construction Flexibility}

A certain degree of impact mitigation could be obtained by designing maximum flexibility into location of GRS support facilities, although little or no flexibility is possible for rectenna panel structures once the location of the borders of the recterma field have been established. Also, individual structures could be designed so that minimal ground disturbance for grading and foundations is required (e.g., rectenna panel arch supports conceivabiy could be of various heights to reducing grading or support pylons could be designed for placement at any of a number of points under the panels to avoid digging in small, sensitive spots). 
Construction schedules and activities could be scheduled to allow for resource salvage operations and monitoring; work might have to be halted in some areas for several weeks if particularly sensitive and unavoidable resources (e.g. burials) were encountered. Certain areas, such as the undisturbed buffer zone and all surrounding lands could be placed "off limits" to all vehicles and construction-related activities. Civil engineering studies could be made of the site to provide for minimal movement or disturbance of sub-surface resources during site preparation. The effectiveness of such measures would be dependent on the extent to which they were employed, as would their cost.

\subsubsection{Resource Survey and Mapping}

Using a 100 percent sample survey, all surface resources within the site could be located in three months at a cost of approximately $\$ 150,000$. Vertical or stratigraphic sampling surveys are considerably more expensive and time consuming, but would be necessary to even estimate the extent, value and sensitivity of subsurface resources. Use of surveys, even those covering 100 percent of the resource, is of limited effectiveness as a mitigation device unless combined with other measures suggested in this sub-section.

\subsubsection{Resource Burial and Vertical Avoidance}

One method of avoiding disturbance to sub-surface resources (and ensuring their preservation for the full project life) is simply to bury them beneath ground materials brought onto the site and dumped over the entire surface area to be used to a depth (approximately one to two meters) sufficient to contain all support foundations, footings, and necessary siting grading. Unfortunately, this would be a prohibitively costly measure to apply on the scale of the GRS project; it also would result in the temporary "destruction" of all surface artifacts and sites being buried and would require the quarrying and removal of vast quantities (several hundred million cubic meters) of ground materials from some other nearby'site.

\subsubsection{Recovery/Salvage of Resources}

The most costly, time consuming, and most effective of resource impact mitigation and protection measures is the' removal of all such resources before project impact occurs. Archaeologic, salvage of surface materials only at the Rose Valley/Coso site alone (inçluding necessary mapping, collection, classification, and laboratory processing) could require over a million man-hours of effort and cost many milliors of dollars. Subsurface recovery and salvage would involve a massive effort that would be al least an order of magnitude greater yet. Clearly, such measures, although highly effective, would not be cost-effective, except if applied on a highly selective basis to protect only the most sensitive and valuable of resources.

\subsubsection{Indirect Impact Mitigation}

Several measures could be employed to minimize the impact of increased use, familiarity, and interest in the cultural resources within and surrounding the site. Public education programs and informational materials could be prepared to alert tourists, sightseers, visitors, and would-be "pot-hunters" to the importance of protecting sensitive cultural resources and values. New access routes, carefully restricted and patrolled by security forces, could 
be created to selected points of high interest, where visitor information centers could be built to display recovered/salvaged resources from the GRS site; all other roads and off-road travel could be restricted from public access, except by special permit (e.g. to Native American groups visiting the Prayer Site or Coso Hot Springs). Onsite protection to newly discovered resources could be obtained by strictly regulating and monitoring construction worker activity near areas of cultural sensitivity and through employment of resident cultural resource management personnel and security patrols. Such measures would ideally be part of a broader cultural resource management and protection plan addressing both direct and indirect impacts resulting from the GRS project.

\subsection{VISUAL RESOURCES}

\subsubsection{VISUAL IMPACTS}

Construction of the GRS in Rose Valley would substantially alter the existing visual environment, replacing 10,500 hectares of lightly vegetated, largely undeveloped land with 2.5 million panels and support structure approximately 6 meters high at their highest point, various structures associated with the electric power collection system and about $45 \mathrm{kilometers} \mathrm{of} \mathrm{gravel} \mathrm{roads.}$ The rectenna field would occupy an area of: only moderate aesthet ic value. In terms of the BLM Visual Resources Management (VRM) classification system, the GRS site is approximately 20 percent VRM Class II, 60 percent VRM Class III, and 20 percent VRM Class IV. (VRM clàsses range from a high preference rating, Class $I$, to a low rating Class $V$. The derivation and further explanation of these classes is included in the environmental setting.) The location and VRM classes of the rectenna field are illustrated in Figure 4.11 l. In addition, a rail spur and a paved access road will be developed and a one-kilometer or more buffer zone surrounding the site will be fenced off and various buildings housing support activities located within this buffer zone. Four or five overhead electrical transmission lines, suspended on steel towers approximately 42 meters high, would lead from the site to utility interties.

Visual disturbance of the whole of Rose Valley would result from siting the GRS rectenna facility as described; disturbance would be most severe in the 20 percent of the rectenna field that is classified as VRM Class II. Disturbance would be largely contained within Rose Valley, as the vallcy runs north-south with mountainous terrain on the east and west. However, some perception of the rectenna field might be possible from the north and/or south. Given a height of 6 meters for the panel/arch assemblies, the rectenna would be visible up to a distance of roughly $45 \mathrm{kilometers}$ when viewed across very flat terrain. It should be noted that there is a small viewing population in the area (e.g. residents, travelers), which, in a sense diminishes the aesthetic impact of the facility.

The $13.4 \mathrm{~km} \times 10 \mathrm{~km}$ rectenna field would, however, be visible from the air and from the higher elevations of the Sierra Nevadas to the west of the site. When viewed from the mountains by air the rectenna will likely resemble a large body of water, since the reflectivity and color of metals are similar to those of water. In addition, radiative heating of air near the earth's surface will cause convective air currents which will give a shimmering appearance to the rectenna, reinforcing the image of a large hody of water. 


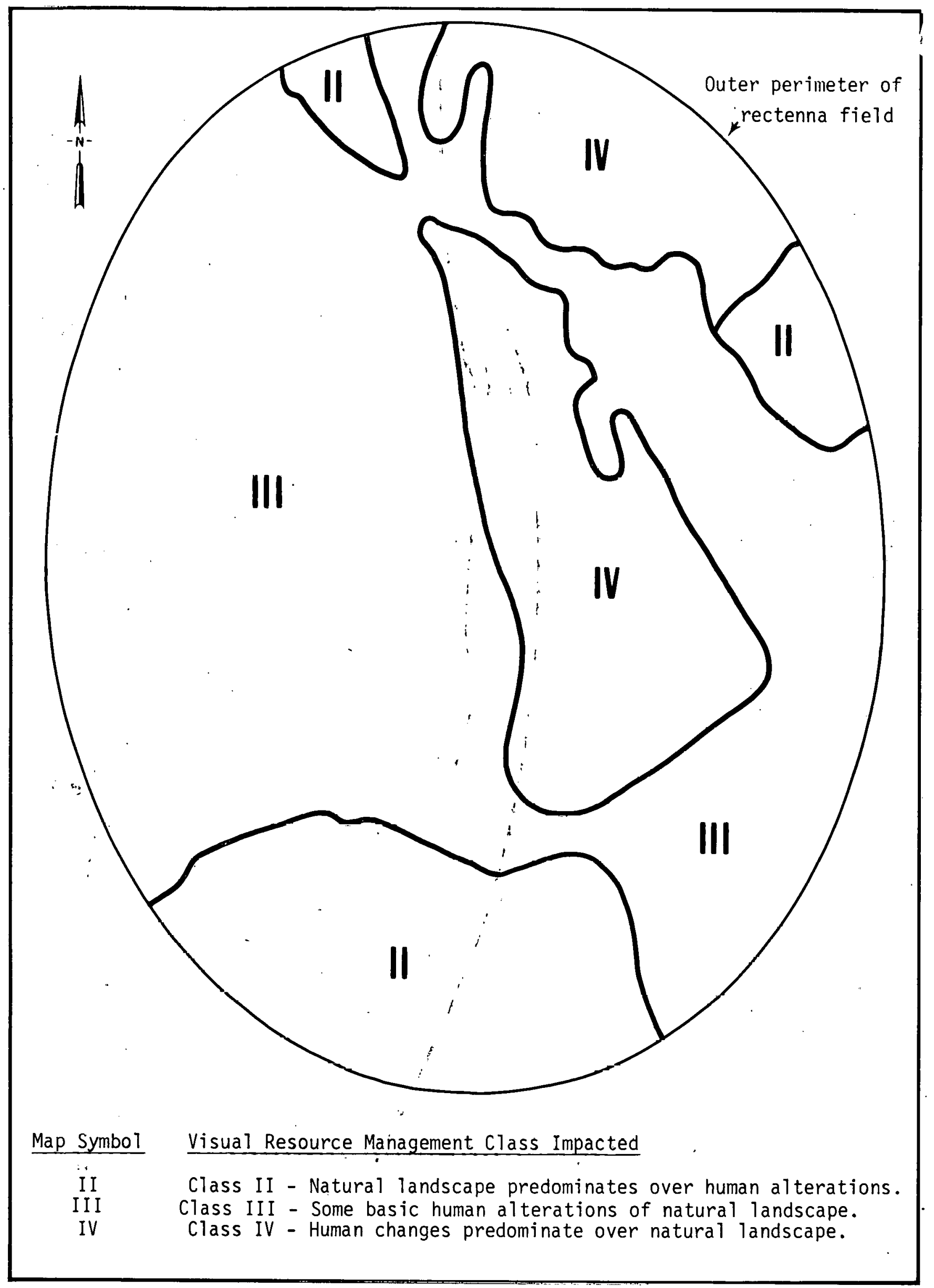

Figure 4.11-1. VISUAL RESOURCE IMPACTS WITHIN GRS SITE 
No smokestacks, cooling towers or significant visible emissions (e.g. stack plumes); would be associated with SPS operations, in contrast to most other electrical generating facilities. Fugitive dust emissions during project construction would temporarily degrade visibili.ty, however. It is not considered likely that there would be significant: visibility impacts during GRS operational phases.

\subsubsection{MITIGATION}

In terms of mitigation, avoidance of particularly scenic areas in site selection would be a prime consideration. Other types of mitigation to be considered include painting GRS structures so that they blend in as much as possible with the natural landscape (e.g. a buff color in a desert environment). It also is conceivable that screening vegetation could be planted around the GRS' periphery. It is noteworthy that this greenery also might absorb some of the incidental radiation received around the periphery of the facility.

\subsection{ELECTRICITY SUPPLY AND DEMAND}

\subsubsection{INTRODUCTION AND APPROACH}

The impact of the proposed GRS on electricity supply conditions in the State of California is characterized by more than the usual number of uncertainties. In addition to the uncertainty associated with the preliminary nature of the SPS reference concept, there is al so the uncertainty inherent in long-term energy forecasting. There is at best a very limited consensus with respect to the future rate of demand growth in the State of California, and there is even less agreement as to the composition of the generating capacity to be developed to meet this demand.

To resolve these uncertainties and to preserve consistency of this prototype Environmental Assessment with the data base developed for the Coso Geothermal Leasing Program Environmental Statement, on which this SPS study is based, an examination of energy and supply and demand effects has been largely restricted to the same timeframe (1995) and the same geographic scope (the State of California) as the Coso geothermal study from which this is adapted. In this context there will be no effort to be consistent with energy supply and demand forecasts being developed at both the national, regional, and state levels as part of other ongoing SPS studies (i.e. "Additional Rectenna Sitings Studies by Allan D. Kotin Economic Consultants and Rice University;" Regional Supply and Demand Effects on SPS Utility Integration" by ERG).

Any consideration of the relationship of a GRS at the Rose Valley/Coso study site to energy supply and demand must deal with three basic questions:

- Will SPS generated electricity be competitive with power supplied from alternative sources at the time that the SPS becomes available?

- Will the size and growth of the market to be served by a generation facility at the Coso location be such as to permit smooth integration of a large single power source at the time when SPS could be completed? 
- Assuming that there are no problems of either cost or scale in integrating the SPS facility at Coso into the electricity utility system, what types of generating capacity is it likely to substitute for or displace?

\subsubsection{COMPETITIVE POSITION OF SPS POWER}

The SPS evaluation program is in its very early stages and the reference concept specifically excludes any attempt to define with precision the projected cost of SPS power. Competitive cost will be a key determinant of whether or not to proceed with further SPS research and development.

In addition, there may be critical policy considerations which do not require a net cost advantage or even cost parity for SPS power. For example, SPS will use a renewable resource and eliminate dependence on either imported fuels or fuels the processing of which create adverse environmental impacts. In California the increasing restriction on new power plant development as a function of air pollution controls in particular, might justify SPS power even at a marginally higher cost than alternative fossil fuel generation sources. Sillildrly, highly restrictive legislation governing the construction of new nuclear plants in the State of California also may create a competitive advantage for SPS power.

The probable costs of alternative power sources in a relevant timeframe in California are considered in an extended discussion of busbar electricity costs contained in Technical Appendix B to the Coso Geothermal Draft ES (U.S. Department of the Interior, Bureau of Land Management, 1980). In 1995, nuclear power plants are projected to have a busbar cost of $\$ 23.5-39.0$ per megawatt hour, while coal power plants are projected to have a cost of $\$ 25.5-48.5$ per megawatt hour. By the year 2000 these costs should have risen to \$24-46 per megawatt hours for nuclear and \$27-58 per megawatt hour for coal generated power. The major el ement in the cost range is the assumption with respect to real escalation in both fuel costs ( $3 \%$ versus $6 \%$ ).

\subsubsection{CAPACITY GROWTH AND THE INTEGRATION OF AN SPS FACILITY}

No current precedent exists for the introduction of a five-gigawatt single unit power plant into the California utility system. The largest existing plants are on the order of 2-2.5 gigawatts. The large size of the SPS also raises the question of the proper framework within which to consider the integration of the SPS. Clearly a power plant of this capacity will serve, through various interties, much of the State of California and, arguably, most other parts of the WSCC (Western States Coordinating Council, a national electrical reliability council planning area which includes all or most of eleven Western states plus the Canadian province of British Columbia).

Projections of growth in electrical capacity in the State of California based largely on local sources indicate that between 1977 and 1995 total capacity will approximately double from 38.0 gigawatts to 73.2 gigawatts. This represents a total increase of 35.2 gigawatts, or an average annual increase of just under 2 gigawatts per year. Based on these projections, a single SPS facility would represent slightly more than 2.5 years of increase for the entire state. This would be a large increase to be absorbed and much higher than the increase associated with individual power plants. Clearly 
there would be an important requirement for advance planning to assure that the introduction of the SPS did not represent redundant or excess capacity. Considered solely in the context of the State of California, the large size relevant to annual growth could be a significant but not insurmountable problem.

Considered in the larger context of the Western States Coordinating Council region, the problem seems much less severe. In one recent source (DOE, 1979) total additions to generating capacity over the period 1979-1988 are projected at 54.53 gigawatts or approximately 5.5 gigawatts per year. In this context the single SPS facility would represent less than one year's increase. To the extent that the transmission intertie has suitable capacity and regionwide planning has evolved appropriately, the integration of a single power plant of this size would present no particular problem.

This DOE study differs in its estimation of growth somewhat from the California state projections and it deals with total additions rather than net increases in generating capacity. To a significant extent total additions are larger due to retirements and derating of existing facilities over the relevant time period. In addition, there is annual data provided in the same DOE study that shows that by 1988 the annual addition will be 7.43 gigawatts. To the extent that this increasing annual growth continues, the introduction of a single 5-gigawatt facility should present progessively less problems in future timeframes. It should be noted that the growth in annual additions to generating requirements is not merely a function of the projected growth rate in electrical demand, but also reflects the increasing rate of retirement and derating of older power plant facilities.

\subsubsection{OTHER TYPES OF GENERATING FACILITIES POTENTIALLY DISPLACED BY THE SPS}

The large scale and distant deployment date for SPS clearly precludes any precise identification of the planned generation facilities that the SPS might displace. At the same time, however, the large scale of the SPS suggests that the displacement effects will probably be distributed over the generation mix in some approximate relationship to the distribution of generation from non-renewable sources, e.g. fossil fuels and nuclear facilities. Some clue to that mixture may be found in the discussion of the current distribution of electrical generating capacity presented in Section 3.14, as well as consideration of some important future vectors that may change this distribution. In 1977, the most important generation source in California was oil (45 percent) followed by natural gas (25 percent) then by coal, nuclear, and hydroelectric all at less than 10 percent. The domination of gas and oil-powered plants should decline over time due to legislative mandates and the increasing cost of oil and gas. In addition, the Power Plant and Industrial Fuel Utilization Act of 1978 should further shift electrical utility generation from gas and oil powered facilities to other uses.

Looking at the regional projections of proposed generating capacity additions for the WSCC region (DOE, 1979) provides some further insight into the mixture of proposed additions over the next eight to nine years. For the period 19791988, approximately 40 percent (22.5 of 54.5 gigawatts) will be fossil steam plants. The next largest component of increased capacity will be nuclear steam plants with 17.8 gigawatts out of 54.5 over the time period. Current plans by utilities within this electrical reliability council (WSCC) indicate 
that in 1988, for example, these proportions will still be roughly. the same, with 4.2 gigawatts in fossil steam and 2.6 gigawatts in nuclear steam out of a total of 7.4 gigawatts of additional capacity scheduled for that year.

In summary, it would appear that under most circumstances, the chief impact of SPS will be to di.splace fossil steam plants, the secondary impact being the displacement of nuclear power plants, since these two dominate new additions in all projections projected for the next ten to seventeen years.

\subsection{TRANSMISSION. LINE IMPACTS}

The following section presents a very brief summary of the generic impacts associated with the development of the transmission system that would connect the 5,000 megawatts of electrical power from an SPS GRS to the regional utility grid. It should be noted that current expectations are that conventional (1.e. nol unique to SPS) transmission systems would be involved with four or five separate transmission lines emanating from the GRS. For a GRS in the Rose Valley/loso area, trdismission lines prcsumably would ronner.t. the GRS to the nearest existing interties, i.e. near Los Angeles and Hoover Dam. Approximately 1,600 kilometers of transmission lines could be required.

The following impact summary is based on studies for two proposed southern California transmission systems (Southern California Edison, 1977 and San Diego Gas and Electric, 1977).

- Air Quality - fugitive dust and minor combustion emissions from transmission line construction and maintenance activities; of rela tively short duration in any given area.

- Noise - noise generated by construction vehicles and equipment, of short duration at any given site; some audible noise from the operating transmission lines during inclement weather (e.g. heavy rain, fog; snow).

- Geology/soils/hydrology - removal or compacliun of soil for access roads; soil disturbance during construction; accelerated soil erosion, increased landslide potential; increased turbidity of receiving surface waterbodies and alteration of drainage patterns.

- Flora - damage and destruction of vegetation during construction; soil disturbance/compaction; permanent vegetation loss at transmission tower accese road sites.

- Fauna - habitat loss at transmission tower ánd access road sites; some fauna loss during construction and temporary disturbance due to construction noise and human encruachment; permanent disturbance due to increased human access via maintenance roads; avifauna losses from collision with towers and lines and electrocution.

- Land use - permanent loss of land (and alternative potential uses) at transmission tower and access road sites; disruption of visual setting for visually sensitive land uses (e.g. wilderness, recreation).

- Socioeconomics - elimination of other development opportunities along transmission route; increased demand for resources such as steel, aluminum, cement and aggregate; increased employment and business 
volume caused by transmission system payroll, materials and equipment. expenditures; social disruption in rural construction areas from

transient construction workers. :

- Cultural resources - possible destruction/modification of archaeological\% historical sites; potential for increased vandalism due to increased access via maintenance roads.

- Visual resources - visual scarring and general disturbance to the scenic quality of the landscape along transmission routes.

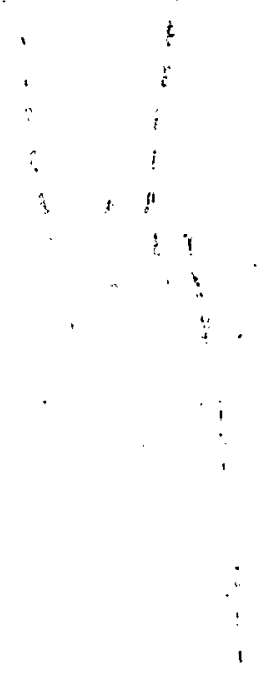




\section{0 'IMPACT SUMMARY}

Table 5.1-1 summarizes, by major technical area, the environmental impacts of GRS development on the Rose Valley/Coso study area. Impacts of both GRS construction and operations are presented; possible mitigation measures also are identified, where applicable. 
Table 5.1-1. SUMMARY OF GRS CONSTRUCTION AND OPERATIONS PHASES ENVIRONMENTAL IMPACTS

\begin{tabular}{|c|c|c|c|}
\hline TECHNICAL AREA & GRS CONSTRUCTION & GRS OPERATIONS & MITIGATION \\
\hline $\begin{array}{l}\text { Air Quality/Clima- } \\
\text { tology }\end{array}$ & $\begin{array}{l}\text { - Probable standards } \\
\text { violation for nitrogen } \\
\text { oxides, particulates } \\
\text { and hydrocarbons } \\
\text { - No climatic impacts }\end{array}$ & $\begin{array}{l}\text { - No significant air quali- } \\
\text { ty impacts } \\
\text { - Unknown, but possibly } \\
\text { significant microclimatic } \\
\text { effects at/near ground } \\
\text { surface }\end{array}$ & $\begin{array}{l}\text { - Adequate dust suppression program } \\
\text { during construction would miti- } \\
\text { gate particulates impacts } \\
\text { - Extending construction schedule } \\
\text { would reduce emission peaks for } \\
\text { hydrocarbons and nitrogen oxides } \\
\text { - Pending further research, project } \\
\text { modifications might be needed for } \\
\text { ground surface microclimate im- } \\
\text { pacts }\end{array}$ \\
\hline Hoise & $\begin{array}{l}\text { - Substantially elevated } \\
\text { noise levels, but very } \\
\text { few human noise recep- } \\
\text { tors in the area } \\
\text { - Possible impacts on } \\
\text { noise sensitive species }\end{array}$ & - No significant impact & $\begin{array}{l}\text { - Improved noise control technology } \\
\text { by GRS implementation time frame } \\
\text { for vehicles, equipment and pro- } \\
\text { cesses (e.g. arch and panel fabri- } \\
\text { cation) would mitigate construc- } \\
\text { tion phase impacts } \\
\text { - During construction, noise sensi- } \\
\text { tive habitats should be avoided } \\
\text { to maximum extent possible during } \\
\text { breeding/nesting seasons } \\
\end{array}$ \\
\hline Geology/Soils & $\begin{array}{l}\text { - Geologic impacts less } \\
\text { important than geologic } \\
\text { constraints } \\
\text { - Study area very active } \\
\text { seismically, but within } \\
\text { normal range for south- } \\
\text { ern Cal ifornia } \\
\text { - Soils impacts signifi-: } \\
\text { cant: large disturbed } \\
\text { area; compaction; wind/ } \\
\text { water erosion } \\
\text { - Soils constraints: di- } \\
\text { versity of soils types } \\
\text { implies variability in } \\
\text { engineering properties } \\
\text { (e.g. shrink/swell po- } \\
\text { tential, corrosivity } \\
\text { to metals/concrete) } \\
\end{array}$ & $\begin{array}{l}\text { - Seismicity has potential } \\
\text { for facility destruction } \\
\text { or loss of efficiency } \\
\text { (alignment vs. satellite) } \\
\text { - Soil productivity impact- } \\
\text { ed for project life: de- } \\
\text { pends on extent and de- } \\
\text { gree of construction } \\
\text { phase and ongoing oper- } \\
\text { ations disturbance }\end{array}$ & $\begin{array}{l}\text { - Thorough seismic and solls studies } \\
\text { required as part of site-specific } \\
\text { engineering } \\
\text { - Careful soil stabilization/drain- } \\
\text { age/erosion control programs re- } \\
\text { quired }\end{array}$ \\
\hline
\end{tabular}


Table 5.1-1 (continued)

\begin{tabular}{|c|c|c|c|}
\hline TECHNICAL AREA & GRS CONSTRUCTION & GRS OPERATIONS & MITIGATION \\
\hline $\begin{array}{l}\text { Hydrology/Nater } \\
\text { Quality }\end{array}$ & $\begin{array}{l}\text { - Project requirements } \\
\text { 2-13 million cubic me- } \\
\text { ters (depends on dust } \\
\text { suppression methods } \\
\text { used) } \\
\text { - Meeting project needs } \\
\text { from groundrater would } \\
\text { lower water table } 0.2 \\
\text { to } 1.5 \text { meters/year; } \\
\text { would reduce underflow } \\
\text { to adjoining valley; } \\
\text { could lower wa:er level } \\
\text { in nearby lake; might } \\
\text { contaminate us able } \\
\text { water through yydraulic } \\
\text { connect ion wit? unus- } \\
\text { able groundwatar } \\
\end{array}$ & $\begin{array}{l}\text { - Project requirements mi- } \\
\text { nor unless major revege- } \\
\text { tation program under- } \\
\text { taken. Revegetation } \\
\text { could require } 27 \text { million } \\
\text { cubic meters/year for } \\
3 \text { years, which could } \\
\text { cause water table draw- } \\
\text { down }\end{array}$ & $\begin{array}{l}\text { - Careful soil stabilization/drain- } \\
\text { age/erosizn control program re- } \\
\text { quirec } \\
\text { - Grouncwater withdrawal impacts } \\
\text { mitijable by importing water from } \\
\text { outside study area } \\
\text { - Proper sewage control program ne- } \\
\text { cessary during construction to } \\
\text { prevzmt water quality degradation }\end{array}$ \\
\hline Flora & $\begin{array}{l}\text { - Land disturjance would } \\
\text { completely nodify } \\
\text { site's floril communi- } \\
\text { ties } \\
\text { - Possible indirect im- } \\
\text { pacts on flora from } \\
\text { hydrologic :hanges, air } \\
\text { and water pollutants } \\
\text { and personnel activi- } \\
\text {-ies } \\
\text { - No endangered species } \\
\text { present at Rose Valleyi } \\
\text { Coso; one rare species } \\
\text { present }\end{array}$ & $\begin{array}{l}\text { - Impacts similar to con- } \\
\text { struction phase } \\
\text { - Microclimate changes at } \\
\text { ground surface a key } \\
\text { issue for severity/miti- } \\
\text { gability of floral im- } \\
\text { pacts }\end{array}$ & $\begin{array}{l}\text { - Reestablishment of preexisting } \\
\text { f ora problematic; major and } \\
\text { difficult revegetation program } \\
\text { reqLired } \\
\text { - Careful placement of ancillary } \\
\text { facilities necessary to minimize } \\
\text { inpccts on sensitive habitats } \\
\text { - Careful planning, design and } \\
\text { construc=ion/operations practices } \\
\text { necessary to minimize indirect } \\
\text { injacts (e.g. water quality de- } \\
\text { gradation) }\end{array}$ \\
\hline
\end{tabular}


Table 5.1-1 (continued)

\begin{tabular}{|c|c|c|c|}
\hline TECHNICAL AREA & GRS CONSTRUCTION & GRS OPERATIONS & MITIGATION \\
\hline Fauna & $\begin{array}{l}\text { - Land disturbance would } \\
\text { completely modify site } \\
\text { faunal communities } \\
\text { - Possible indirect im- } \\
\text { pacts on fauna from } \\
\text { hydrologic changes, air } \\
\text { and water pollutants, } \\
\text { personnel activities } \\
\text { and loss of feeding } \\
\text { areas for nearby fauna } \\
\text { - Surface water sources } \\
\text { for migratory water and } \\
\text { land birds would be } \\
\text { lost (playas) and jeo- } \\
\text { pardized (Little Lake) } \\
\text { One protected species } \\
\text { (Mohave ground squir- } \\
\text { rel) found in Rose } \\
\text { Valley } \\
\end{array}$ & $\begin{array}{l}\text { - Impacts similar to con- } \\
\text { struction phase } \\
\text { - Impacts closely related } \\
\text { to flora impacts } \\
\text { - Microclimate changes at } \\
\text { ground surface a key } \\
\text { issue for severity/miti- } \\
\text { gability of fauna impacts } \\
\end{array}$ & $\begin{array}{l}\text { - Reestablishment of preexisting } \\
\text { faunal problematic; closely linked } \\
\text { to strategy/success of floral mit- } \\
\text { igation } \\
\text { - Careful placement of ancillary } \\
\text { facilities needed to minimize im- } \\
\text { pacts on sensitive habitats } \\
\text { - Careful planning, design, con- } \\
\text { struction and } 08 \text { prim practices and } \\
\text { construct ion scheduling needed } \\
\text { to avoid indirect impacts and to } \\
\text { avoid sensitive habitats during } \\
\text { breeding/nesting seasons } \\
\end{array}$ \\
\hline Land Use & $\begin{array}{l}\text { - Total displacement of } \\
\text { existing site uses } \\
\text { (e.g. farming, grazing, } \\
\text { recreation) } \\
\text { - Minor loss of mineral } \\
\text { resources (cinder, pu- } \\
\text { mice) } \\
\text { - Minor indirect (growth- } \\
\text { related) impacts } \\
\text { - Potent ial land acquisi- } \\
\text { tion/use conflicts with } \\
\text { Navy (China Lake NWC), } \\
\text { energy (geothermal), } \\
\text { wilderness, archae- } \\
\text { ological resources, } \\
\text { Native American use/ } \\
\text { access to cultural/ } \\
\text { religious sites }\end{array}$ & $\begin{array}{l}\text { - Same as construction } \\
\text { phase }\end{array}$ & - Major impacts not mitigable \\
\hline
\end{tabular}


Table 5.1-1 (continued)

\begin{tabular}{|c|c|c|c|}
\hline TECHN!CAL AREA & GRS ZONSTRUCTION & GRS OPERATIONS & MITIGATION \\
\hline Sacioeconamics & $\begin{array}{l}\text { - Rose Val ley/Coso siting } \\
\text { would create peak em- } \\
\text { ployment of } 3,200 \text { jobs } \\
\text { in area } \\
\text { - Population inmigration } \\
\text { (3,900) would strain } \\
\text { local infrastructure } \\
\text { somewhat: (e.g. housing, } \\
\text { government services); } \\
\text { impacts would be more } \\
\text { severe in more remote } \\
\text { area } \\
\text { - Relatively small in- } \\
\text { creased gavernment } \\
\text { costs in Bose Valley/ } \\
\text { Coso; relatively smal1 } \\
\text { increase in government } \\
\text { revenues (if GRS pub- } \\
\text { licly owned) }\end{array}$ & $\begin{array}{l}\text { - Rose Valley/Coso siting } \\
\text { would create } 800 \text { new jobs } \\
\text { in area } \\
\text { - Permanent population } \\
\text { growth (2,300) absorbable } \\
\text { with relatively mi nor im- } \\
\text { pacts; impacts would be } \\
\text { more severe in more re- } \\
\text { mote area } \\
\text { - Relatively small increas- } \\
\text { ed governmental costs; } \\
\text { relatively small tax base } \\
\text { growth (if GRS publicly } \\
\text { owned) }\end{array}$ & $\begin{array}{l}\text { - Provision of sizable onsite con- } \\
\text { struction personnel housing facil- } \\
\text { ities a key mitigation element } \\
\text { - Extending GRS construction sche- } \\
\text { dule would reduce socioeconomic } \\
\text { impact peak } \\
\text { - Care-ul advance planning needed } \\
\text { to prevent "boomtown" growth } \\
\text { problems, part icularly in areas } \\
\text { more remote than Rose valley/Coso }\end{array}$ \\
\hline Cultural Resources & $\begin{array}{l}\text { - Total disruption of all } \\
\text { archaeolocical/histori- } \\
\text { cal resources within } \\
\text { rectenna field site } \\
\text { - Access oo nearby cul- } \\
\text { tural sites would be } \\
\text { disrupted } \\
\end{array}$ & $\begin{array}{l}\text { - Same as construction } \\
\text { phase }\end{array}$ & $\begin{array}{l}\text { - Impacts hard to mitigate if GRS } \\
\text { site is rich in cultural re- } \\
\text { sourzes } \\
\text { - Salvage of resources possible } \\
\text { before construction, but would } \\
\text { be extremely expensive if signi- } \\
\text { ficant resources present }\end{array}$ \\
\hline Visual Rescurces & $\begin{array}{l}\text { - Complete visual modi- } \\
\text { ficatici of site, but } \\
\text { Rose Val ley/Coso not } \\
\text { high in scenic value } \\
\text { - Facility rould be visi- } \\
\text { ble from cir and from } \\
\text { Sierra Nevadas } \\
\text { - Increased fugitive dust } \\
\text { would riave temporary } \\
\text { visibility impact }\end{array}$ & $\begin{array}{l}\text { - Impacts, same as con- } \\
\text { struction phase except } \\
\text { that no significant dust } \\
\text { emissions expected (visi- } \\
\text { bility impact) }\end{array}$ & $\begin{array}{l}\text { - Facility should be designed (e.g. } \\
\text { painted) to maximize harmony with } \\
\text { natural surroundings } \\
\text { - Screening vegetation could be } \\
\text { planted around GRS periphery }\end{array}$ \\
\hline
\end{tabular}


Table 5.1-1 (continued)

\begin{tabular}{|l|l|l|l|}
\hline TECHNICAL AREA & GRS CONSTRUCTION & GRS OPERATIONS & MITIGATION \\
\hline $\begin{array}{l}\text { Electricity Supplý } \\
\text { and Demand }\end{array}$ & $\begin{array}{l}\text { Electricity demand } \\
\text { estimated at } 16 \text { MW at } \\
\text { Rase Valiey/Coso }\end{array}$ & $\begin{array}{l}\text { Major source of basel oad } \\
\text { electric power } \\
\text { 5-GW GRS would represent } \\
\text { about 2.5 years of pro- } \\
\text { jected Cal ifornia annual } \\
\text { Capacity growth and } \\
\text { roughly one year of pro- } \\
\text { jected growth for Western } \\
\text { Systems Coordinating } \\
\text { Council (regional power } \\
\text { pool) }\end{array}$ \\
\hline
\end{tabular}




\subsection{CRITICAL PROJECT PARAMETERS}

\subsection{INTRODUCTION}

This prototype assessment of the environmental impacts of an SPS GRS has revealed that many significant GRS impacts are directly attributable to a relatively few characteristics, or critical parameters, of the GRS. The study also revealed a number of specific constraints on GRS design that stem from environmental factors. This chapter discusses some of these impacts and constraints and their relationship to critical project parameters. A final section identifies a number of the engineering parameters that relate specifically to the design of the rectenna elements (i.e. panels and their support arches).

\subsection{SIZE AND INTENSITY OF GRS LAND REQUIREMENTS}

Foremost among the critical project parameters revealed in this prototype environmental assessment is the sheer size of and intensivity of use of the contiguous land area required by àn SPS GRS. Roughly 11,000 hectares must be totally committed to SPS $(10,500$ hectares for the rectenna field plus additional area for support facilities, access roads, etc.), a decision that would lead to complete displacement of existing land uses and total modification of the existing natural environment. In comparative terms, the nearest paral lel to the GRS land utilization impact would be the creation of a manmade lake or reservoir; there is no parallel to SPS land requirements for any existing fossil fuel or nuclear electrical generating facility.

\subsubsection{LACK OF FLEXIBILITY IN SITING RECTENNA FIELD ELEMENTS}

Closely related to the size of the contiguous area that is required for a GRS is the lack of flexibility in siting the elements that comprise the rectenna field. Once the coordinates of the rectenina field boundaries are established, the intensivity of rectenna field land use means that there is essentially no flexibility in siting individual rectenna structures." Thus, the ability to avoid specific sensitive areas (e.g. a unique biological habitat, an important archaeological site) is greatly diminished. This factor complicates the problem of finding suitable GRS sites because one cannot reconfigure the project to avoid a particular sensitive area -- and avoidance is generally the first type of mitigation measure considered.

\subsubsection{SITING-RELATED LAND USE CONFLICTS}

Finding 100 square kilometers that are topographically and geographically (i.e. of sufficient size both north-south and east-west) suitable for a GRS and do not involve conflicts between SPS and other environmental or societal values is not an easy proposition. This prototype tnvironmental Assessment illustrates this point. Although the Rose Valley/Coso study area contains relatively little of unique value biologically (i.e. endangered species or unusual habitats) there is a permanent freshwater body (Little Lake) and intermittent surface water (desert playas) on and adjacent to the study site that would be destroyed (playas) or potentially jeopardized (Little Lake) and that are important for migratory and wintering bird species. 
Moreover, the southern portion of Rose Valley is extremely rich in archaeological resources; a 300-hectare area has been nominated for the National Register of Historic Places,as the Fossil Falls Archaeological District. While not all areas of the Basin and Range Physiographic Province (which covers a large portion of the southwest), are as archaeologically significant as Rose Valley, Rose Valley also is not unique in the region in possessing valuable archaeological resources.

Further, there are other potentially serious land use conflicts illustrated by Rose Valley/Coso. The area contains a geothermal energy resource. While the highest potential geothermal area is slightly to the east of Rose Valley, it is not certain that the geothermal resource does not extend into Rose Valley. Geothermal potential is fairly widespread in the southwest in general, although, of course, not literally everywhere throughout the region.

Likewise, the potential conflict between many national defense-related land uses, such as the China Lake Naval Weapons Center which extends into the Rose $\mathrm{Valley/Coso}$ study site, is likely to be encountered elsewhere in the southwest. Numerous large, unpopulated areas in the southwest are currently in use (or proposed) for national defense purposes. For example, in the Cal ifornia desert alone, there are the China Lake NWC, the Mojave and Chocolate Mountains Gunnery Ranges, George and Edwards Air Force Bases, Fort Irwin and the Twentynine Palms Training Center. To put this into perspective, of the 6.5 million hectares comprising the California Desert Conservation Area (CDCA), the federal government owns almost 5.5 million hectares. Slightly over 1.0 million hectares, or 15 percent of the entire CDCA, are withdrawn for use by the Department of Defense. Other western states, such as Nevada (the Nellis Air Force Range, the Fall on Gunnery Range, the Nevada Test Site) and Arizona (the Luke Air Force Range and the Yuma Proving Ground) also have major DOD facilities. The possible deployment of the Air Force's MX intercontinental ballistic missile system in the eastern Nevada/western Utah portions of the Basin and Range illustrates the continuing interest of DOD in the southwestern desert and the potential conflicts with GRS siting in these areas.

\subsection{BIOLOGICAL IMPACTS}

GRS site preparation requirements are such (i.e. the site must be completely cleared, grubbed, graded and compacted) that GRS construction would completely and perhaps irrevocably (for the life of the project) alter the existing biological environment of the site. It also should be noted that even if a possible GRS site contains no plant or animal species that are rare or endangered, developing a tract of land of the size of an SPS GRS increases the probability that new species will become rare or endangered.

The existing ecosystem over the roughly 100 square kilometer rectenna field area would be totally destroyed during rectenna construction and it is problemmatic whether anything resembling the preexisting interrelated floral and faunal communities could be reestablished after construction is completed. The reasons for this are the altered environmental conditions of the site, and perhaps also the operational requirements of the GRS itself.

There are critical uncertainties, that will require further research, relating to the issue of reestablishment of the naturally occurring ecosystems of the GRS site. Primary among these are questions relating to the microclimatic conditions (temperature, humidity, wind, precipitation) in the first few 
centimeters above the ground surface beneath the rectenna panels. Desert fauna are quite narrowly adapted to their particular ecological niches, e.g. desert herbivores are dependent on a few specific types of plants for their food source. Thus, relatively minor climatic changes at and near the ground surface, if they alter the nature of the floral communities that can establish themselves, inevitably will alter the faunal species composition, starting with the herbivores and extending all the way up to the top predators in the food chain.

Given that insolation will be altered beneath the panels; that wind patterns will be altered by the presence of the rows of rectenna panels; that precipitation/infiltration patterns will be altered by soil disturbance and compaction, and by the drainage system that must be installed over the 10,500-hectare rectenna field, it appears inevitable that ground surface microclimates will be different because of the rectenna's presence, although the nature of these differences is unclear.

Further, it is not at all clear that the reestablishment of native vegetation is compatible with GRS operations, at least in a desert environment. For example, many desert plant species are highly flammable and it obviously would be difficult to control a brush fire within the rectenna field without considerable damage to the facility. Thus from the perspective of protecting the GRS from fire, it may not be possible to permit (much less encourage) growth of naturaliy occurring vegetation. Fire retardant plant species could be considered (although they also burn, albeit less easily and rapidly), but these may not be native to the particular siting area.

Further, to stabilize the soil within the rectenna field for purposes of wind and water erosion control, it could be necessary to apply soil stablilizing chemicals (irrespective of the mitigation of biological impacts). Use of such chemicals could well affect the nature and extent of vegetative and faunal reestablishment.

\subsection{ARCHAEOLOGICAL IMPACTS}

The size and intensity/lack of flexibility in land use within the rectenna field have implications for archaeological resources that are difficult if not impossible to mitigate. Although it is possible (and not uncommon) to undertake major excavations in order to salvage archaeological resources that conflict with an impending project, such resource retrieval operations can be extremely expensive, e.g. up to $\$ 1,000$ or more per cubic meters of excavation. Given the size of the rectenna field, if there were significant resources to be recovered (including sites that are several meters deep, which is not uncommon in areas with lengthy prehistoric human use), an archaeological mitigation program at a GRS site, even in an area with fewer known archaeological resources than Rose Valley, could cost millions of dollars.

\subsection{SITE SELECTION IMPLICATIONS OF GRS LAND USE, BIOLOGY AND ARCHAEOLOGY IMPACTS}

As described above, GRS land requirements are large, intensive (all existing uses must be displaced), and inflexible in terms of siting individual elements of the rectenna once its boundaries are established. Extant biological and cultural resources inevitably would be severely affected. This leads to the following observation regarding SPS site screening/evaluation/selection: 
thesé efforts must focus on identifying suitable potential GRS sites that are larger than minimum GRS requirements (about 11,000 hectares, excluding the buffer zone). While it is not possible to identify the optimal size site (i.e. how much bigger than the minimum requirement), a larger site would preserve a measure of flexibility in rectenna field placement that would be unavailable in a site barely of sufficient size. This flexibility potentially would allow avoidance or at least reduction in conflicts between the GRS and competing land uses and/or significant biological or cultural resources, and otherwise suitable site (or sites) could be preserved for SPS purposes that otherwise might have to be abandoned completely.

\subsection{WATER REQUIREMENTS}

Another critical environmental parameter for GRS siting, particularly in arid regions is the supply of sufficient water of adequate quality, particularly during project construction. During GRS operations, water requirements would be relatively small, unless a major revegetation program is undertaken (which could require millions of cubic meters of water per year for three years). While GRS operational water requirements would be significantly smaller than for thermal (coal or nuclear) power plants which require huge amounts of cooling water (on the order of 18-30 million cubic meters annually per 1,000 megawatts), GRS construction water demand still could be significant in many areas.

At Rose Valley/Coso, unlike much of the Basin and Range, there probably would be sufficient water physically available for GRS needs, though a definitive assessment would depend on which of a fairly wide range of project construction requirements and, in turn, dust suppression methods are employed. However, there could well be displacement of other water users (in Rose valley this would mean the loss of several hundred hectares of alfalfa farming). Elsewhere in the southwest, it is more likely that either water would have to be imported from outside the GRS site vicinity or overdrafting of groundwater would occur.

\subsection{ENGINEERING IMPLICATIONS OF GRS SITE SIZE}

The size of the site also poses a number of engineering problems, that presumably could be solved, but deserve note. A sizable drainage system would be required to cope with runoff from 10,500 hectares from the infrequent, although powerful thunderstorms that occur in the desert. The drainage issue, and the related problem of erosion control, must be handled properly to avoid sedimentation of downstream water courses (such as Little Lake in Rose Valley), as well as to protect the GRS itself. Also, a 10,500-hectare area is likely (as is the case in Rose Valley) to have a multiplicity of soil types, perhaps with different engineering properties. This conceivably could create different engineering and construction requirements at different locations within a single rectenna field.

\subsection{GRS 24-MONTH CONSTRUCTION SCHEDULE}

The 24-month construction schedule (25 months including one month for startup and testing) has a number of potentially significant environmental implications. These relate to socioeconomic impacts on the siting region, peak construction phase impacts on air quality, water requirements and biological resources, and possibly logistical problems for GRS construction itself. 


\subsubsection{SOCIOECONOMIC IMPACTS}

GRS construction over a two-year period would involve a nine-month peak workforce of 3,200, with an average workforce of 2,500. The most environmentally critical factor with respect to the GRS workforce is the level of inmigration of construction personnel and dependents (as well as secondary employees) that would be associated with GRS development. The larger the existing population base of the GRS siting area, the fewer inmigrants would be required, the greater the capacity of the area to absorb this growth and consequently the less of a strain on the entire socioeconomic fabric of the area. Peak construction phase population growth for a Rose Valley/Coso facility would be roughly 3,900 .

Rapid growth in areas with relatively undeveloped infrastructure and a small population base can pose substantial problems (see Section 4.9): overloaded schools, hospitals, roads, housing supply, governmental services, etc.; an inability by local governments to plan for and finance the required infrastructure improvements to cope with this growth when it occurs; adverse impacts on the social fabric of stable, homogeneous rural communities; a perceived decline in the quality of life by many residents.

In an area such as Rose Valley/Coso, with a population base of over 25,000, and with a source of additional labor in the Antelope Valley within range of a long daily commute, the socioeconomic effects of GRS construction would impose some, but not overwhelming strains on the local area, assuming that the GRS project provides onsite housing for a sizable proportion of the construction workforce. In areas with a smaller population base, GRS socioeconomic impacts would be more severe. The interrelationship of socioeconomic effects and the construction schedule involves the size and duration of construction phase inmigration. If the same amount of labor (in man-hours) were spread out over a longer period of time, then the size of the inmigrant GRS construction workforce at any one time and the associated population growth-related impacts would be reduced.

\subsubsection{AIR QUALITY, WATER RESOURCE AND BIOLOGICAL IMPLICATIONS}

An extended construction period al so would reduce peak air pollutant emissions, by extending the same volume of pollutant emissions over a longer period of time, it would reduce the intensity of project water demands for the same reason as with air emissions. It also would allow somewhat more flexibility in scheduling construction activities so as to minimize impacts on sensitive animal habitats during critical times of the year (e.g. breeding and nesting seasons).

\subsubsection{LOGISTICAL PROBLEMS FOR GRS CONSTRUCTION}

It should be noted that the 24-month schedule could imply substantial logistical problems, particularly with regard to the delivery to the site of construction materials to the site. During Months 9-15, when rectenna support structure fabrication and foundation installation are scheduled, enormous amounts of materials will be required, (e.g. about IU.I million tonnes of aggregate, 1.4 million tonnes of cement, 370,000 tonnes of steel). As described in Chapter 2 of this report, if all of this material were delivered by truck, the equivalent of 2,400 heavy trucks per day would be required. Delivery of this volume of material by rail would imply 6.2 100-car unit 
trains per day. Even assuming (as is likely) that some combination of these two transportation modes were employed, considerable logistical problems stemming from the truck/train arrivals and departures, as well as unloading, storage and distributing this volume of material, could arise. Severe strains might be placed on the local transportation infrastructure and an additional rail spur might be required, or local highways expanded to accommodate the peak GRS construction phase traffic loads. If these activities were spread out over a longer period of time, i.e. a longer total construction period, these problems would be reduced, because the volume of deliveries at any given time would be reduced.

\subsubsection{RESOURCE IMPACTS}

GRS development would require significant quantities of several materials, particularly aggregates (11,000,000 tonnes) and cement $(1,400,000$ tonnes) to be used in producing an estimated 6,500,000 cubic yards of concrete, and steel (1,700,000 tonnes). It is conceivable that SPS demand for these materials could have some impact on their regional availability (and/or price). To put requirements in perspective, the total 1978 California production of aggregates (sand and gravel), cement and steel was roughly 100 million, 8.1 million and 2.1 million tonnes, respectively. Thus a single SPS GRS would consume roughly 11 percent of total annual Cal ifornia aggregates productions, 17 percent of the state's cement production and 81 percent of California's steel production (although California is not a major steel producing state). It should be noted that an extended GRS construction schedule, for these materials would reduce GRS impacts on the overall regional supply/ demand for these materials at any given time, by spreading the same total. demand over a longer period of time.

\subsection{PUBLIC VS. PRIVATE OWNERSHIP}

Another key project parameter is whether the GRS is publicly owned or privately owned. If the facility is publicly owned then relatively minor tax revenue benefits would accrue to the local jurisdictions. Construction materials purchases, for example, would not be taxable; more importantly, there would be no increase in the property tax base of the siting area. Tax revenues provide the resources with which to develop and maintain the infrastructure to cope with project-caused growth. If the GRS is publicly owned and consequently non-taxable, then the fiscal burdens of GRS development would be imposed on the local area without the tax base increases to compensate for the increased burden. Private ownership, by contrast, would significantly increase the local tax base. As described in Section 4.9, a $\$ 1.7$ billion GRS in California would produce $\$ 17$ million in property tax revenues in its first full year of operation, if it was privately owned.

\subsection{PANEL AND ARCH DESIGN}

The SPS rectenna consists of literally millions of panels, each supported by steel-reinforced concrete arches. Because of their extraordinarily high number of identical components, the design and properties of these relatively small pieces can have.significant environmental implications. Some observations on a number of these factors are presented below. 
- The rectenna panels should be as light and open as possible. This would allow both sunlight and precipitation to reach the ground surface with a nearly natural distribution, which could greatly enhance the possibility of reestablishing a native floral community.

$\cdots$ This, in turn, would help to control fugitive dust emissions.

- Design of the panels and their diode/dipole elements must take into account certain natural phenomena: (1) snow, ice and moisture, which would impair efficiency; (2) the possible attractiveness of the panels as resting areas for avian species, and of the dipoles as perches; (3) the attractiveness of the panels as rodent resting areas and the possible inclination of rodents to gnaw on the vast amount of rectenna cables and wires - control of rodents over an area of 10,500 hectares may prove to be a formidable task, hence the panel design should offer some rodent proection; and (4) protection for the rectenna panels and concrete supports from the alkaline soils that are often encountered in desert areas, and which may chemically attack panels and supports. In addition, protection must be afforded from the abrasive efferts of severe dust storms.

- The effects of rectenna development on microclimatic conditions at/near the ground surface. Careful evaluation of factors such as insolation, waste heat rejection, rectenna albedo and surface aerodynamics may enable design of a rectenna which has minimal climatological impacts. In addition, proper aerodynamic design might serve to help control fugitive dust emissions.

- Rectenna design must take into account seismic factors, particularly in earthquake prone areas such as the California desert.

- The rectenna panels, arches and footings require enormous quantities of concrete and steel. The rectenna design process should consider ways to minimize the use of these materials. This would affect many environmentally significant elements of GRS development, including water requi rements, electricity requirements, transportation needs, air pollution and solid waste production. 


\section{BIBLIOGRAPHY}

Amimoto, P.Y. Erosion and Sediment Control Handbook, Cal ifornia Division of Mines and Geology. Published by U.S. Environmental Protection Agency, Water Planning Division. Washington, D.C., EPA 440/3-78-003. 1978.

Armbrust, D.V. and J.D. Dickerson. "Temporary Wind Erosion Control: Cost and Effectiveness of 34 Commercial Materials." Journal of Soil and Water Conservation. 1971.

Ayensu, E.S. and R.A. De Fillipps. Endangered and Threatened Plants of the United States. Washington, D.C. Smithsonian Institution and World Wildlife Fund, Inc. T978.

Boeing Aerospace Co. Solar Power Satellite System Definition Study, Part III. Preferred Concept System Definition. 1978.

Bondel 10, M.C. and B.H. Battstrom. The Experimental Effects of Offroad Vehicle Sounds on Three Species of Desert Vertebrates. Report to the Bureau of Land Management. 1979.

Chanlett, E.T. Environmental Protection. 1973.

City of Oxnard (California). Proposed Oxnard Liquefied Natural Gas Facilities, Final Environmental Impact Report. 1976.

Coffman, J.L. and C.A. von Hake. Earthquake History of the United States, Revised Edition. National Oceanic and Atmospheric Administration, Publication 41-1. 1973.

Davidson, E. and M. Fox. "Effects of Off-Road Motorcycle Activity on Mojave Desert Vegetation and Soil." Madrono. 1974.

Eakin, T.E., D. Price, and J.R. Harrill. Summary Appraisals of the Nation's Ground-Water Resources -- Great. Basin Region. U.S. Geological Survey Professional Paper 813-G. 1976.

General Electric, Space Division. Solar Power. Satellite System Definition Study, Part 4 -- Phase I Final Report.. 1979.

Hill, M.R. "The Great Owens Valley Earthquake of 1872," in California Geology. 1972.

Hodges, Laurent. Environmental Pollution. New York. Holt, Rinehart and Winston, Inc. 1973.

Institute of Geophysics and Planetary Physics, University of California at Los Angeles. Study of Alternative Locations of Coal-Fired Electric Generation Plants to Supply Energy from Western Coal to the Department of Water Resources. May 1977.

International Conference of Building Officials. Uniform Building Code. 1979 edition. 
Jennings, C.W. Fault Map of California. California Division of Mines and Geology, California Geological Data Map Series, Map No. 1. 1975.

Kaiser Steel Corp. 1978 Annual Report. Oakland, CA. 1979.

Lee, J-L, D.M. Rote and H.D. Orville. "Workshop on Meteorological Effects of Satellite Power System Rectenna Operation, 23-25 August, 1978, Chicago, I11." Bulletin of the American Meteorological Society. '1979.

Los Angeles County Department of Regional Planning. Quarterly Bulletin. No. 143. 1979.

Los Angeles Department of Water and Power (LADWP). Intermountain Power Project Preliminary Engineering and Feasibility Study. 1976.

- San Joaquin Nuclear Project Draft Environmental Impact Report, Revised. 1975.

MacMahon, J.A. "Species and Guild Similarity of North American Desert Mammal Faunas: A Functional Analysis of Communities," in Godall, D.W., ed., Evolution of Desert Biota. Austin, TX. Universily uf Texas Press.

Moriba, George. Environmental Science. 1974.

Moore, J.W. and E.A. Moore. Environmental Chemistry. New York. Academic Press. 1976.

Mountain West Research, Inc. "Construction Worker Profile." Prepared for the 01d West Regional Commission. 1975.

Munz, P.A. A California Flora and Supplement. Berkeley, CA. University of California Press. 1968.

- A Flora of Southern California. Berkeley, CA. University of California Press. 1974.

Oak Ridge National Laboratory. Regional Energy Balance Statement, PIES Mid Mid Scenario, 1990. October 1979.

Port of Long Beach. Final Environmental Impact Report SOHIO West Coast to MidContinent Pipeline Project. 1976.

Powell, W.R. Inventory of Rare and Endangered Vascular Plants of California. California Native Plant Society. 1974.

Rand Corporation. Energy Mlternatives for California: Paths to the Future. 1975.

Real, C.R., T.R. Toppozada, and D.L. Parke. Earthquake Epicenter Map of California, 1900 through 1974. California Division of Mines and Geology, Map Sheet 39.

Rockwell International. Satellite Power Systems (SPS) Concept Definition Study. 1979. 
Ruderman, H., et al. An Energy-Environmental Data Book for the States of Cal ifornia, Hawai i, and Nevada. Lawrence Berkeley Laboratories, LBL-7821. 1978.

Ryal1, A. "Earthquake Hazard in the Nevada Region." Seismological Society of America, Bulletin. 1977.

Schnabel, P.B. and H.B. Seed. "Accelerations in Rock for Earthquakes in the Western United States." Earthquake Engineering Research Center, College of Engineering, University of California, Berkeley, Report No. EERC 722. 1972.

Salvato, Joseph A. Environnental Engineering and Sanitation. New York. Wiley-Interscience. 1972.

Southern California Edison Company (SCE). Devers-Palo Verde $500 \mathrm{kV}$ Transmission Line Environmental Report. 1977.

State of California. California Statistical Abstract-1979. Sacramento, CA. 1979.

State of California, Office of the Controller. 1977-78 Annual Report of Financial Transactions Concerning Cities of California. Sacramento, CA. 1979.

- 1977-78 Annual Report of Financial Transactions Concerning Counties of California. Sacramento, CA. 1979.

State of California 'Public Utility Commission. Final Environmental Impact Report for the Point Conception LNG Terminal Project. 1978.

Turner, D.B. and A.D. Busse. User's Guide to the Interactive Versions of Three Point Source Dispersion Programs: PTMAX, PTDIS AND PTMTP. National Environmental Research Center, Office of Research and Monitoring, U.S. Environmental Protection Agency. 1973.

United Engineers and Constructors (UEC). Capital Cost: High and Low Sulfur Coal Plants - 1200 MWe. 1977.

U.S. Department of Energy, Economic Regulatory Administration. "Additions to Generating Capacity 1979-1988 for the Contiguous Unived States, as Projected by the Regional Electric Reliability Councils in their April 1, 1979 Long Range Coordinated Planning Reports to the Department of Energy. DOE/ERA-0020/1. 1979.

U.S. Department of Energy, Office of Energy Research. Preliminary Environmental Assessment for the Satellite Power System (SPS), Revision I, Volume 2: Detailed Assessment. October 1979. - Satellile Puwer Syslem (SPS) Program Summary. 1978.

U.S. Department of Energy and the National Aeronautics and Space Administration. Satellite Power System, Concept Development and Evaluation Program, Reference System Report. 1978.

U.S. Department of Labor, Bureau of Labor Statistics. Consumer Expenditure Survey, 1972-73. 1973. 
U.S. Department of Labor, Bureau of Labor Statistics. "Los Angeles Area Consumer Price Index." 1979.

U.S. Department of the Air Force. Final Environmental Impact Statement, MX: Milestone II. T979.

- MX Missile System Site Selection Focusing Studies. 1979.

U.S. Department of the Interior. West-Central North Dakota Regional Environmental Impact Study. 1978.

U.S. Department of the Interior, Bureau of Land Management. Draft Environmental Statement, Intermountain Power Project. 1979.

U.S. Environmental Protection Agency. Compilation of Air Pollutant Emission Factors AP-42. Office of A1r Quality Planning and Standards. Washington, D.C. 1975.

- Mobile Source Emission Factors. Office of Air and Waste Management, Final Document EPA400/1-78-005. Washington, D.C. March 1978.

- Noise from Construction Equipment and Operations. EPA Report PB-206-717. 1971.

U.S. Nuclear Regulatory Commission. Draft Environmental Statement Sundesert Nuclear Plant. 1978.

Vasek, F.C., H.B. Johnson and D.H. Eslinger. "Effects of Pipeline Construction on Creosote Bush Scrub Vegetation of the Mojave Desert." Madrono. 1975.

Vasek, F.C., H.B. Johnson, and G.D. Brum. "Effects of Power Transmission Lines on Vegetation of the Mojave Desert." Madrono. 1975.

Wells, P.V. "Succession in Desert Vegetation of Streets of a Nevada Ghost Town." Scienre. 1961.

Whittaker, R.H. Communities and Ecosystems. London. Macmillan. 1975.

Wilshire, H.G. and J.K. Nakata. "Offroad Vehicle Effects on California's Mojave Desert." U.S. Geological Survey, Menlo Park, CA. California Geology. 1976.

PERSONS CONTACTED

Allen, R. United Engineers and Constructors. Philadelphia, PA.

Andryczyk, R.W. General Electric Company, Space Division. Philadelphia, PA.

Benson, H.E. Johnson Space Center. Houston, TX.

Bergin, K. Los Angeles County Sanitation District. Los Angeles, CA.

Brown, P.E. United Engineers and Constructors. Philadelphia, PA. 
Calahan, D. National Aeronautics and Space Administration. Washington, D.C. Campbel1, R. Conrock Company, Los Angeles, CA.

Conessa, W. Witco Chemical Corporation. Bakersfield, CA.

Cherry, W. City of Los Angeles Public Works Department, Sanitation Bureau. Los Angeles, CA.

Dickinson, R.M. Jet Propulsion Laboratory. Pasadena, CA.

Fath, K. Santa Fe Railway Company. Los Angeles, CA.

Feldmeth, C.R. Joint Science Department, Claremont Colleges. Claremont, CA.

Guttman, C.E. National Aeronautics and Space Administration, Marshall Space Flight Center, Huntsville, AL.

Hanley, G.M. Rockwell International Space System Division. Downey, CA.

Johnson, B. Los Angeles Department of Water and Power. Los Angeles, CA.

Johnson, L: Los Angeles Department of Water and Power. Los Angeles, CA.

Lang, H. Conrock Company. Los Angeles, CA.

Livingston, L.E. National Aeronautics and Space Administration, Johnson Space Center. Houston, TX.

Moyer, J. Southern California Edison Company. Rosemead, CA.

Packer, M. City of Los Angeles Department of Airports. Los Angeles, CA.

Pierce, M. Conrock Company. Los Angeles, CA.

Piland, R.0. National Aeronautics and Space Administration, Johnson Space Center. Houston, TX.

Ross, J. Sierra Sands Unified School District. Ridgecrest, Ca.

Schwenk, C. National Aeronautics and Space Administration. Washington, D.C.

Sc of ield, R. TRW, Inc. Redondo Beach, CA.

Straughan, I.R. Southern California Edison Company. Rosemead, CA.

Terry, J. City of Los Angeles, Department of Water and Power. Los Angeles, CA.

Von Flue, F. Rockwell International Space System Division. Downey, CA.

Woodcock, G.R. Boeing Aerospace Co. Seattle, WA.

Ziegler, E.J. United Engineers and Constructors. Philadelphia, PA. 


\section{THIS PAGE \\ WAS INTENTIONALLY \\ LEFT BLANK}




\section{INTRODUCTION}

As explained in Chapter 1 , environmental assessments require a reasonably detailed description of the proposed project's environmentally salient features. Such information regarding the siting and construction of Ground Receiving Stations (GRS) was largely unavailable in existing SPS definition documents. Therefore, these data had to be developed to serve as a basis for the prototype environmental assessment of GRS siting and construction.

In general, environmental assessments do not required the precise data which are a normal constituent of project engineering studies: environmental impacts are rarely sensitive to the precision, in terms of project design detail, that is required for engineering purposes. A distinction also must be made between sitespecific environmental assessments, performed in the context of meeting legal requirements (i.e. the National Environmental Policy Act) prior to commencing construction, and prototype assessments (such as this report). This prototype assessment will provide order-of-magnitude impacts to identify areas of environmental sensitivity at an early stage for input to future project design efforts, to identify topics for further study, etc. As such, generalized concepts and descriptions, in conjunction with order-of-magnitude estimates of fuel consumption, water requirements, labor needs, etc. are considered to provide a reasonable basis for this prototype environmental assessment of GRS siting and construction.

\section{LABOR REQUIREMENTS}

The labor requirements for the construction period are tabulated in Table A-1. The scheduling assumes a 25 month construction period (General Electric, 1979). The phasing of operations is centered about the use of Months 9-15 for rectenna support structure manufacture and installation and Months 16-24 for rectenna panel manufacture and installation. Labor requirements for the individual tasks were estimated using various data and assumptions as follows (175 man-hours/manmonth was assumed, unless noted otherwise):

(1) Initial site survey work force requirements are those specified in the General Electric Rectenna construction analysis (General Electric, 1979).

(2) Main Road - Requirements were based on an assumption of 2,000 man-hours/ $\mathrm{km}$ for a roughly seven-meter wide road which was determined using United Engineers and Constructors estimates (UEC, 1977).

(3) Railroad - An estimate of 8,700 man-hours/km was used (UEC, 1977).

(4) Yardwork - The figure of 70,000 man-hours was taken from the figure for general yardwork in the UEC 1,200 MWe coal plant capital cost study (UEC, 1977).

(5) Typical Construction Facilities - The figure of 800,000 man-hours was determined by subtracting the figure for general cleanup from the total man-hours for temporary construction facilities in the UEC coal-fired power plant study (UEC, 1977). 
Table A-1. LABOR REQUIREMENTS FOR GRS CONSTRUCTION1

Tasks

Labor Requirements

Man-hours Workforce Required

Period of Construction Schedule (Months)

Prel iminary Construction

Activities

(T) Initial Site Survey

(2) Main Road $(16 \mathrm{~km})$

(3) Rail road $(16 \mathrm{~km})$

(4) Yardwork

(5) Typical Construction

Facilitias

(6) Special Construction Facilities

(7) Rectenna Field Site Preparation

$\begin{array}{rrr}4,000 & 20 & 1-2 \\ 32,000 & 90 & 1-2 \\ 140,000 & 100 & 1-8 \\ 70,000 & 70 & 3-8 \\ 800,000 & 760 & 3-8 \\ 400,000 & 380 & 3-8\end{array}$

$1-2$

$1-8$

$3-8$

$3-8$

3-8

Rectenna Construction Arch Manufacture \& Installation

Panel Manufacture \& Installation

Power Collection

System Construction

(9) Power Collection System

800,000

500

$16-24$

$9-15$

$16-24$

3-11

$1,700,000$

1,600

1,100

$16-24$

Additional Construction \&

Pre-Operation Activities

(10) Control Center \& Other Permanent Structures

(11) Equi pment Maintenance

(12) General Cleanup

$1,800,000$

1,100

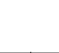

(13) Startup and Testing

(14) Administration \& [ngineering

\begin{tabular}{rcc}
$1,700,000$ & 1,100 & $16-24$ \\
180,000 & 50 & $3-24$ \\
440,000 & 200 & $16-24$ \\
55,000 & 700 & 25 \\
830,000 & 310 & 25 \\
& (variable) & $1-25$ \\
\hline
\end{tabular}

TOTAL

$10,000,000$

2,500 (average)

25

1. See text for explanation and derivation of data. 
(6) Special GRS Construction Facilities - The labor required for the setup of the concrete plant, and the arch and panel factories was estimated at half the labor required to build the typical construction facilities required for a coal-fired power plant (UEC, 1977).

(7) Rectenna Field Site Preparation - Rockwell indicates that about 43 man-hours/hectare would be required for rectenna field site preparation (Rockwell, 1979), a good estimate for flat, sparsely vegetated sites. A figure of 160 man-hours/hectare was assumed here (UEC, 1977, 1979), since the Coso site is not perfectly flat.

(8) Rectenna Construction - Labor estimates are based on figures for machine productivity and number of men required per machine presented in the General Electric rectenna construction analys is (General Electric, 1979); workforce figures are based on the number of men per machine multiplied by shifts required as specified in the General Electric study. These labor and workforce estimates were then summed for all tasks required for rectenna construction.

(9) Electric Power Collection System - Labor estimates were developed in consultation with United Engineers (UEC, 1979) for the $200 \mathrm{MW}$ collector/ transformer stations and the $100 \mathrm{MW}$ step-up switching stations, which are expected to require a total of approximately 760,000 man-hours. The installation of the 125 converter stations and the busses and cabling required for the power collection system could bring the labor requirement to about 800,000 man-hours.

(10) Control Center and Other Permanent Structures - For instrumentation and control facilities of a coal power plant, 30 percent of the total cost is labor cost at an average of about $\$ 13$ per hour (without burden) (UEC, 1977). Assuming that the Rockwell $\$ 75$ million cost estimate for the control center (Rockwell, 1979) was prepared using unburdened payroll costs, and that 30 percent of this cost is for labor at $\$ 13$ per hour, then 1.7 million man-hours would be required. The other permanent structures are expected to have insignificant labor requirements compared with the control center.

(11) Equipment Maintenance - Assuming that 1.7 percent of total site labor is required for equipment maintenance, as for a coal plant (UE.C, 1977), 180,000 man-hours would be required.

(12) General Cleanup - The requirements for temporary construction facilities were estimated to be about 1.5 times the amount required for a coalfired plant (UEC, 1977), and the same multiplier was used here.

(13) Startup and Testing - Startup and testing labor is about 0.2 percent of total on-site construction labor for a coal-fired power plant (UEC, 1977), or about 21,000 man-hours. Startup and testing labor accounts for 0.08 percent of the capital cost of a coal-fired plant (UEC, 1977). 
Assuming labor at $\$ 11 /$ man-hour and a $\$ 2$ billion GRS (including the transmission system), then this 0.08 percent translates into roughly 145,000 man-hours for startup and testing. It was assumed that the geometric mean of these two values, 55,000 manhours, would be required for GRS startup and testing.

(14) Administration and Engineering - Labor was assumed to be 8 percent of total construction site labor; this estimate is based on requirements for field job supervision and quality assurance (UEC, 1977). The workforce at the site would be a function of total labor at the site, and vary with time accordingly. Construction site labor excludes labor for transmission lines; administration and engineering requirements for transmission lines are included in the labor requirements for these facilities.

\section{MATERIALS REQUIREMENTS}

In Table A-2 the materials requirements for GRS construction are tabulated. Requirements for the main road are based on data presented in a preliminary engineering feasibility study done for the Intermountain Power Project (LADWP, 1976). The data for rail spur construction are based on estimates provided in the Draft Environmental Impact Report for the San Joaquin Nuclear Project (LADWP, 1975). Materials requirements for perimeter fencing, rectenna construction, and roads within the rectenna field were estimated by General Electric (General Electric, 1979).

Materials requirements for the electric power collection system are based on the Boeing definition study (Boeing, 1978). The $40 \mathrm{MW}$ converter stations ( $2 \mathrm{kV}$ dc to $69 \mathrm{kV} \mathrm{ac}$ ) are relatively small and would probably be delivered to the site assembled and ready for installation. The $200 \mathrm{MW}$ collection/transformer stations and the 1,000 MW step-up stations would be constructed at lie site; materials requirements for these stations were estimated in the following manner. Data were available for two switching stations totalling 1,720 MW (LADWP, 1975), and the materials requirements for these stations were multiplied by a scaling factor of $5000(\mathrm{MW}) / 1720(\mathrm{MW})$.

Data for the materials requirements for construction activities not included in Table A-2, such as yardwork, installation of temporary construction support facilities, equipment maintenance, general cleanup, startup and testing, and administration and engineering were not readily available. The requirements for these activities were not considered to be significant relative to the overall materials requirments for GRS construction, and no estimates have been made. These activities account for only four percent of the non-labor cost of a 1,200 MW coal-fired power plant (UEC, 1977), and would probably comprise an even smaller fraction of non-labor GRS construction costs.

Materials requirements for the permanent ancillary buildings are not presented in current SPS literature, although a cost estimate of $\$ 75$ million has been given for the control center (Rockwell, 1979). Such buildings would require a very small fraction of the materials required by the rectenna itself. 
Tabie A-2. MATERIALS REQUIREMENTS FOR GRS CONSTRUCTION

\section{Material Requirements}

\begin{tabular}{|c|c|c|c|c|c|c|c|c|}
\hline It tems & $\begin{array}{l}\text { Aggregates } \\
\text { \& Bal last } \\
\text { (thousand } \\
\text { tonnes). }\end{array}$ & $\begin{array}{l}\text { Cement } \\
\text { (thousand } \\
\text { tonnes) }\end{array}$ & $\begin{array}{l}\text { Concrete } \\
\text { (thousand } \\
\text { cu. yds.) }\end{array}$ & $\begin{array}{l}\text { Steel } \\
\text { (thousand } \\
\text { tonnes) }\end{array}$ & $\begin{array}{l}\text { Aluminum } \\
\text { (thousand } \\
\text { tonnes) }\end{array}$ & $\begin{array}{l}\text { Plastic } \\
\text { (thousand } \\
\text { tonnes). }\end{array}$ & $\begin{array}{l}\text { Ceramic } \\
\text { (thousand } \\
\text { tonnes) }\end{array}$ & $\begin{array}{l}\text { Diodes } \\
\text { (number) }\end{array}$ \\
\hline
\end{tabular}

A. Preliminary Con-

struction

Main Access Road (10 mi)

Rail road (10 mi)

Perimeter Fencing

$(45 \mathrm{~km})$

$97(1$

130

$(1$

$22(2$

100

1.0

$\rightarrow$ B. Rectenna Field Site

Preparation

Gravel Roads $(45 \mathrm{~km}) \quad 100$

C. Rectenna Construction

T. Support Manufacture

and Installation

Foundations

$\begin{array}{rrr}6,500(3 & 900(3 & 4,200 \\ 3,280(3 & 450(3 & 2,100 \\ 300(3 & 70(3 & 200\end{array}$

4,200
2,100

370

Arches $300(3$

200

2. Panel Manufacture

and Installation

Manufacture

Installation

\& Wiring

1,200
110

57

1.4

5.8

$7.4 \times 10^{9}$

110

11

0.06 
Table A-2. MATERIALS REQUUIREMENTS FOR. GRS CONSTRUCTION (continued)

\begin{tabular}{|c|c|c|c|c|c|c|c|c|}
\hline \multirow[b]{2}{*}{ Items } & \multicolumn{6}{|c|}{ Material Requirements } & \multirow[b]{2}{*}{$\begin{array}{l}\text { Ceramic } \\
\text { (thousand } \\
\text { tonnes) }\end{array}$} & \multirow[b]{2}{*}{$\begin{array}{l}\text { Diodes } \\
\text { (number) }\end{array}$} \\
\hline & $\begin{array}{l}\text { Aggregates } \\
\& \text { Bal last } \\
\text { (=housand } \\
\text { tonnes) }\end{array}$ & $\begin{array}{l}\text { Cement } \\
\text { (thousand } \\
\text { tonnes; }\end{array}$ & $\begin{array}{l}\text { Concrete } \\
\text { (thousand } \\
\text { cu. yds.) }\end{array}$ & $\begin{array}{l}\text { Steel } \\
\text { (thousand } \\
\text { tonnes) }\end{array}$ & $\begin{array}{l}\text { Al uminum } \\
\text { (thous and } \\
\text { tonnes.) }\end{array}$ & $\begin{array}{l}\text { Plastic } \\
\text { (thousand } \\
\text { tonnes) }\end{array}$ & & \\
\hline D. Electric Power Col- & & . & & . & . & - & & \\
\hline $\begin{array}{l}\text { Electric Power } \\
\text { Collection }\end{array}$ & $4.6 r^{3}$ & $0 . 6 \longdiv { 3 }$ & 2.9 & 5.2 & 0.2 & & & \\
\hline $\begin{array}{l}\text { E. Additional Cons- } \\
\text { truction and Pre- } \\
\text { Operation Activities }\end{array}$ & V.A. & N.A. & N.A. & N.A. & N.A. & N.A. & N.A. & N.A. \\
\hline TOTAL & 11,003 & , ,400 & 6,500 & 1,700 & 170 & 16 & 6 & $7.4 \times 10^{9}$ \\
\hline
\end{tabular}

1. Cement àd aggregate for asphaltic concrete not included.

2. Asphaltic concrete.

3. For non-asphaltic concrete. 


\section{MAJOR VEHICLE AND EQUIPMENT REQUIREMENTS AND FUEL CONSUMPTION}

The major vehicle and equipment requirements and fuel consumption are described in detail for those construction activities which, after preliminary analysis, were determined to have the potential for significantly contributing to peak or near-peak environmental impacts (e.g. noise, air pollution). Vehicle and equipment use and fuel consumption are greatest during the period of concurrent rectenna field site preparation, and support structure manufacture and installation (Months 9 through 11), and the period of panel manufacture and installation (Months 16 through 24). Vehicle and equipment use during the other months of the construction schedule is very low when compared to these two construction phases.

Requirements for the control center are uncertain because the physical nature of the facility remains undefined (Rockwell, 1979). Since the major part of the $\$ 75$ million cost of this facility is expected to cover expensive computing and other electronic equipment, the labor, vehicle and equipment use and fuel requirements are expected to be negligible,compared to overall GRS requirements.

\section{RECTENNA FIELD SITE PREPARATION}

Based on the labor requirements estimated previously (Section 1 above) approximately 770 men will be required for rectenna field site preparation each day during the 9 month work period. Assuming the same ratio of major equipment to daily crew requirements suggested by Rockwell (Rockwell, 1979), then 185 road graders, 138 bulldozers, 138 dump trucks, 94 cranes and 47 backhoes would be required, or a total of about 600 vehicles. Some water trucks are also expected to be required for dust suppression.

If it is assumed that 5 percent of the vehicles are on standby, but that the operating vehicles work eight hours per day, about 4,600 machine-hours per day are required. If $80 \mathrm{~kg} / \mathrm{mach}$ ine-hour is assumed for an average fuel consumption (General Electric, 1979), then about 370 tonnes of fuel are used by these vehicles each day. For the full nine-month task, 100,000 tonnes of fuel will be required.

\section{RECTENNA CONSTRUCTION}

According to the General Electric construction analysis (General Electric, 1979), the support structure fabrication and installation phase of rectenna construction will require a substantial number of vehicles and equipment. For the installation of footings for the arch foundations, 20 survey vehicles, 250 auger-jackhammer machines, 3 rock drills, 200 concrete pouring footing machines, and 90 concrete trucks will be required. Ten arch-making factories (in the arch factory complex) will be required to produce the arches. For the installation of the arcines, 63 trailer-trucks, 60 manipulating cranes, and 3 concrete trucks will be required.

For the manufacture of the rectenna panels, 120 foreplane assembly machines, 6 panel assemblers, and 3 panel testing machines will be required. For the installation and hookup of the panels, $65 \mathrm{flatbed}$ trucks, 30 manipulating cranes, 15 cabling machines, 6 panel wiring machines, 1 frame press, 1 end press, and 4 unit cabling machines will be required.

Using the machine performance figures from the General Electric construction analysis, and with the task requirements of each set of machines, the minimum number of machine hours required for each type of machine is easily calculated; 
using figures given by General Electric for fuel consumption per hour of operation for each machine, overall fuel consumption figures can be obtained. Table A-3 summarizes the requirements for machinery and fuel consumption for rectenna construction.

\section{ELECTRIC POWER COLLECTION SYSTEM CONSTRUCTION}

Based on the requirements for the switching stations for the San Joaquin Nuclear Project (LADWP, 1975), which are expected to have construction requirements similar to the major components of the electric power collection system of the GRS, construction equipment will include cranes, earthmovers, trucks, bulldozers, backhoes, compactors, graders, and water trucks may al so be required. Using the scaling factor discussed above (Appendix A, Section 2), it is estimated that about 980,000 liters of gasoline and diesel fuel will be required during the nine month construction period.

Since no estimates were available for the number of vehicles and machines required for construction of the power collection system, or for the San Joaquin Nuclear Project switching stations, the vehicle/workforce ratio for trallsilission line construction (640/900) was applied to obtain an estimated requirement of 360 vehicles and machines.

\section{UTILITY REQUIREMENTS}

\section{ELECTRICITY CONSUMPTION}

The Intermountain Power Project (IPP) will have a peak electricity demand of five MW for construction (DOI, 1979), and the San Joaquin Nuclear Project SJNP estimates average electricity consumption at 1.5 MW (LADWP, 1975). In consultation with United Engineers and Constructors (UEC, 1979), it was estimated that peak demand for GRS construction would not exceed $10 \mathrm{MW}$.

The GRS construction-related inmigrant population will also consume electricity. The peak size of this population is estimated at 3,900 (see Section 4.11). Since the average annual power consumption is $753 \mathrm{~W} /$ person in California (Rand, 1979), the labor force and its dependents will demand a maximum annual average of roughly 3 MW. Assuming a residential load factor of 0.5 (Terry, 1979), peak demand would be about $6 \mathrm{MW}$.

It follows that GRS construction would cause a maximum increase in local electricity demand of roughly $16 \mathrm{MW}$.

WATER CONSUMPTION

There are three main sources of water consumption during GRS construction: concrete production, dust suppression and labor force-related consumption. 
Table A-3. RECTENNA CONSTRUCTION MACHINE AND FUEL REQUIREMENTS1

\begin{tabular}{|c|c|c|c|c|}
\hline Task & $\begin{array}{l}\text { Machines } \\
\text { (Number) }\end{array}$ & $\begin{array}{l}\text { Machines-Hours } \\
\text { Required }\end{array}$ & $\begin{array}{l}\text { Rate of Fuel } \\
\text { Consumption } \\
\text { (kg/hour) }\end{array}$ & $\begin{array}{l}\text { Fuel } \\
\text { Consumption } 2 \\
\text { (tonnes) }\end{array}$ \\
\hline $\begin{array}{l}\text { Survey } \\
\text { Dig Footings } \\
\text { Drill Footings } \\
\text { Pour Footings } \\
\text { Move Concrete } \\
\text { Make Arches } \\
\text { Move Arches } \\
\text { Set Arches } \\
\text { Move Grout } \\
\text { Make Foreplane } \\
\text { Assemble Panel } \\
\text { Test Panel } \\
\text { Move Panel } \\
\text { Instal I Panel } \\
\text { Install Cable } \\
\text { Attach Cable Ends } \\
\text { Stamp Racks. } \\
\text { Join Panel Ends } \\
\text { Unit Wiring }\end{array}$ & $\begin{array}{r}20 \\
250 \\
3 \\
200 \\
90 \\
10 \\
63 \\
60 \\
3 \\
120 \\
6 \\
3 \\
65 \\
30 \\
15 \\
6 \\
1 \\
1 \\
4\end{array}$ & $\begin{array}{r}6,200 \\
370,000 \\
2,500 \\
370,000 \\
160,000 \\
15,000 \\
66,000 \\
120,000 \\
2,700 \\
710,000 \\
41,000 \\
21,000 \\
66,000 \\
83,000 \\
41,000 \\
41,000 \\
2,500 \\
2,500 \\
7,300\end{array}$ & $\begin{array}{r}6 \\
100 \\
30 \\
40 \\
75 \\
175 \\
15 \\
100 \\
75 \\
250 \\
100 \\
5 \\
70 \\
70 \\
10 \\
10 \\
30 \\
30 \\
50\end{array}$ & $\begin{array}{r}37,000 \\
70 \\
15,000 \\
12,000 \\
2,600 \\
1,000 \\
12,000 \\
200 \\
180,000 \\
4,100 \\
100 \\
4,600 \\
5,800 \\
400 \\
400 \\
70 \\
70 \\
70\end{array}$ \\
\hline TOTAL & 950 & $2,100,000$ & & 270,000 \\
\hline
\end{tabular}

1. Source: General Electric, 1979.

2. A specific gravity of 0.85 is assumed. 
Concrete Production

Using the data provided by General Electric (General Electric, 1979), it is estimated the GRS will require 6.6 million cubic yards of concrete. Each cubic yard will require roughly 0.115 cubic meters of water for concrete mixing and an additional 10-20 percent will be needed to wet the footing holes into which the concrete is poured (UEC, 1979). Hence, concrete production will require about 910,000 cubic meters of water.

It has been suggested (UEC, 1979) that the estimate of 6.6 million cubic yards of concrete may be low by nearly a factor of two. If the higher value obtains, water requirements would be increased to roughly 1.8 million cubic meters.

\section{Labor Force Consumption}

Assuming a peak labor force-related population of 3,900 and per capita water consumption of 0.6 cubic meters per day (Sdlvato, 1972), the labor forco will have a maximum consumption of 850 thousand cubic melers/year.

\section{Dust Suppression}

The suppression of fugitive dust emissions arising from site clearing and grading (as well as access roads) will require repeated applications of water or a mixture of water and dust-suppressing chemicals. The amount of water applied per application varies over a wide range of values depending upon climate, soil conditions, and chemicals added to the water. The application rate can range from 0.40 cubic meters/hectares -application to 57 cubic meters/hectares-application (Armbrust, 1971). Assuming 20 applications to the rectenna field during construction (a rather high estimate), a field size of 10,500 hectares, and that water comprises 90 percent of the liquid volume applied for dust suppression, the water required for dust suppression would range from 75 thousand to 11 million cubic meters.

The maximum annual water consumption for GRS construction (including concrete production, personnel-related consumption, and dust suppression) will be between 1.8 - 13.7 million cubic meters depending primarily upon the method used to control fugitive dust emissions.

SOLID AND LIQUID WASTES

SOLID WASTES

There are four main sources of solid waste production resulting from GRS construction: rectenna field site preparation, rectenna panel manufacture, administration and enginepring, and the labor force.

Rectenna Field Site Preparation

The Rose Valley rectenna field site is covered largely by typical desert scrub plant communities with plant species such as shadscale (Atriplex confertifolia), burro weed (Ambrosia dumosa), and creosote bush (Larrea tridentata) belny lhe most common plant cover. Using a mean figure for plant biomass density of 0.7 dry kilograms per square meter for desert scrub (Whittaker, 1975), it is calculated that 7.0 dry tonnes of vegetation per hectare will require disposal after 
clearing and grubbing operations. The entire rectenna field site will yield about 74,000 dry tonnes of solid waste. However, the living vegetation is estimated to have a water content of about 85 percent (Feldmeth, 1979). Therefore, the actual mass of vegetation to be removed and handled is estimated to be about 47 tonnes per hectare or 490,000 tonnes for the entire rectenna field site, which is 1,800 tonnes per day on average.

\section{Rectenna Panel Manufacture and Installation}

The solid waste production rates of the fabricated metals industry and the electrical machinery industry are each estimated at 1.5 tonnes/employee/year (Salvato, 1972), and such work seems approximately analgous to panel manufacture. Therefore a workforce of 1,100 in panel manufacturing and installation would produce, roughly 1,300 tonnes of solid waste in nine months, or 4.7 tonnes/day.

\section{Administration and Engineering}

Data presented in the Intermountain Power Project study (LADWP, 1976) indicate that $1,600 \mathrm{~m}^{2}$ of temporary office space would be required for 150 administrative and engineering personnel. Assuming a peak administrative and engineering workforce equivalent to eight percent of the peak GRS workforce $(3,200)$, and a solid waste production rate of $0.48 \mathrm{~kg} / 10 \mathrm{~m}^{2}$-day (Salvato, 1972), then the waste production rate would be $130 \mathrm{~kg} /$ day.

\section{Labor Force Community}

Given a peak construction-related population of 3,900, and a solid waste production rate of $2.5 \mathrm{~kg}$ per day per capita (Salvato, 1972), then 9.8 tonnes/day of solid waste will be produced at the peak of construction activity.

\section{LIQUID WASTES}

The main source of 1 iquid wastes for the GRS construction project will be the sewage production of the labor-related population. A sewage flow rate of 380 liters per day per capita was assumed for the Intermountain Power Project labor community (LADWP, 1976) and is commonly applied (Salvato, 1972). If a sewage flowrate of 0.38 cubic meters per day per capita is assumed for a peak constructionrelated population of 3,900 , then a total flow of 1,500 cubic meters/day is expected.

Other potential sources of liquid waste problems are concrete production and arch fabrication, aggregate washing, surface precipitation runoff (which could include dust suppressing agents), and the disposal and leakage of oils and greases from vehicles and machines (9.5 liters waste 0 il/vehicle-year) (Salvato, 1972).

\section{GRS CONSTRUCTION COSTS}

GRS construction costs are tabulated in Table A-4. Cost estimates for the various construction tasks were based on the Boeing and Rockwell SPS definition studies, the General Electric rectenna cost study, documents published by southern California utilities, and capital costs studies of power plants performed by United Engineers and Constructors (UEC). Non-labor costs are defined as the difference between total costs and labor costs. 
Table A-4. GRS CONSTRUCTION COSTS IN 1977 DOLLARS (in thousands of dollars)

Tasks Labor Non-Labor ${ }^{1}$ Total Cost

Preliminary Construction Activities

Initial Site Survey

Main Road2.

Rail Spur ${ }^{3}$

General Yardwork

Typical Construction Facilities

Special Construction Facilities

Rectenna Field Site Preparation .

Rectenna Construction

Arch Malluracture and Installation

Panel Manufacture and Installation

Electric Power Collection System

Construction

Electric Power Collection System

Other Construction and Pre-0peration Activities

Control Center

Equipment Maintenance

General Cleanup

Startup and Testing

- Administration \& Engineering

60
350
$1,500^{r}$
8860
8,900
4,500

20.000

25,000

24,000

280,000

300,000

$1,100,000$

$1,100,000$

9,600

110,000

120,000

$$
\begin{array}{r}
22,000 \\
1,600 \\
4,400 \\
600 \\
7,500
\end{array}
$$

100
1,400
3,100
2,200
14,000
7,200

50,000

30,000

TOTAL

130,000

$1,600,000$

$1,700,000$

1. Non-labor costs include materials and fuel costs.

2. A nominal $16 \mathrm{~km}$ of road were assumed.

3. A nominal $16 \mathrm{~km}$ of rall line were assumed. 
The data tabulated in this section are intended to serve as input data for the section of the prototype environmental assessment dealing with socioeconomic impacts. The data are very general and were developed for this prototype assessment, rather than as a precise definition of GRS construction costs. The compilation of GRS construction costs did not include certain costs such as land acquisition costs, off-site engineering and design costs, inflation and financing costs during the construction period, contingency. costs, and costs for construction and payroll insurance, social security, and fees and permits.

Data presented in UEC's 1,200 MWe plant cost study of coal-fired power plants (UEC, 1977) were used to estimate costs for the main road, rail spur, general yardwork, typical construction facilities, special construction facilities, equipment, general cleanup, and administration and engineering. The same methods were used in the application of cost data from the UEC study as were used in the derivation of labor requirements based on UEC data (see Section 1). UEC's July: 1,1976 costs were escalated by seven percent, for consistency with cost estimates in SPS documents which are expressed in 1977 dollars.

Rectenna field site preparation and electric power collection system labor costs are the product of required labor hours and a wage rate of $\$ 12 /$ hour, based on labor costs presented in the UEC study (UEC, 1977). Total costs for the electric power collection system were assumed approximately equal to the Rockwell estimate for its converter station ( $\$ 120$ million), in the absence of cost estimates for. the Boeing system. The control center total cost is as provided by Rockwell. (Rockwel1, 1979). Labor cost was estimated assuming $\$ 13 /$ hour which is the approximate hourly rate used by UEC (UEC, 1977) for installation of instrumentation and control for a coal power plant. It was al so assumed that labor comprised 30 percent of the control center's total cost (see Section 1 above).

Cost estimates from the General Electric rectenna construction analysis (General Electric, 1979) were used directly for the rectenna construction element. The three-month detailed site survey cost which appears as a separate item in the study (General Electric, 1979) is included as part of the cost for arch manufacture and installation. Initial site survey cost was estimated by using cost estimates from General Electric for the three-month detailed site survey task and multiplying by a factor of $2 / 3$ ( $i . e$. , assuming a two month initial survey).

The General Electric cost estimates for rectenna construction include vehicle and equipment maintenance and servicing. Therefore, equipment maintenance costs do not include maintenance of vehicles and equipment used for rectenna construction. 
THIS PAGE

\section{WAS INTENTIONALLY \\ LEFT BLANK}




\section{APPENDIX B}

\section{SOCIOECONOMIC ASSUMPTIONS}

The following appendix discusses a number of simplifying assumptions that were used in developing the assessment of GRS socioeconomic impacts on the Rose Valley/Coso study area. These assumptions have, for the most part, been derived from published research reports and environmental assessment documents.

\section{EMPLOYMENT-RELATED ASSUMPTIONS}

\section{EMPLOYMENT MULTIPLIERS}

The employment multipliers used in this report are 1.2 for the two year construction period and 1.8 for the GRS operations phase. The small size of the multipliers is due to the "ruralness" of the study area and the need to import most goods and services from the nearby Los Angeles metropolitan area. The difference between the two multipliers is due to the temporary nature of construction activities and the high percentage of daily and weekly commuters from outside the study area. The construction multiplier of 1.2 was taken from West-Central North Dakota Regional Environmental Impact Study on Energy Development (U.S. DOI, 1978) and the Draft Environmental Statement Sundesert Nuclear Plant, Units 1 and 2 (NRC, 1978). The permanent employment multiplier of 1.8 was taken from the Coso Geothermal Lease Program DES (U.S. DOI, Bureau of Land Management, 1980).

\section{INMIGRATION}

The majority of the GRS construction workers are expected to come from outside the study area. The construction workforce is expected to average 2,500 and it is expected that 20 percent (500 workers) will be hired locally. Another 10 percent (250 workers) are expected to commute daily from the Antelope Valley some $170 \mathrm{kilometers}$ to the south. The estimate of local hires and daily commuters was derived from the Construction Worker Profile (01d West Regional Commission, 1975). This study found that 40 percent of power plant construction workers were local (i.e. they lived within $160 \mathrm{kilometers} \mathrm{of} \mathrm{the} \mathrm{project} \mathrm{site).} \mathrm{This}$ "local" percentage has been reduced to 30 percent (20 percent study area plus 10 percent daily commuters) in this report for two reasons: 1) the LancasterPalmdale area of the Antel ope Valley is slightly more than 160 kilometers from the Rose Valley site, which would reduce the number of daily commuters, and 2) the 01d West Regional Commission report predated the latest (and continuing) increase in fuel prices which should further reduce long distance commuting. The remaining 70 percent of the average construction workforce $(1,750)$ are expected to inmigrate from outside the study area.

An operational GRS site would require 450 permanent workers, with an average daily workforce of 300 . The additional 150 workers are required to allow for days off and vacations for all workers. All of these workers are expected to move to the local area from (most likely) the Los Angeles urban area. These jobs, in general, require skills largely unavailable in the local area.

Family sizes associated with inmigrant permanent workers and two-year construction employees are assumed to be 2.7. This family size is the 1977 average for Los ingeles County and should be a good approximation of inmigrant family sizes. 
Since family size is projected to decline between now and the year 2000, the estimates derived in this report may represent a worst case. Construction workers who commute weekly or daily are assumed to have a family size of one.

RESIDENTIAL LOCATION AND HOUSING

The general distribution of worker residences is assumed to be 80 percent to the Ridgecrest area and 20 percent to the southern Inyo County area. This residential distribution is taken from the moderate impact scenario of the Coso Geothermal Lease Program DES and represents a realistic assessment of the most likely population dispersal. This 80-20 split applies to local hires, permanent employee inmigrants, indirect workers, and construction workers expected to be on the job for two years. The $80-20 \mathrm{split}$ does not apply to workers commuting daily from the Antelope Valley nor to workers living in the onsite construction worker housing.

Of the 1,750 inmigrant workers, approximately 200 (supervisors and equipment maintenance workers) are expected to be on the job for two years. These workers are assumed to live in permanent housing and will locate in Inyo county and Ridgecrest as described above. Another 150 workers will choose to 1 ive in transient housing (motels) in Ridgecrest and Inyo County. The remaining 1,400 workers will live in the onsite temporary housing and will commute home on weekends. These assumptions have been derived from the assumptions on housing demand vs. length of employment presented in the California Public Utility Commission's Final Environmental Impact Report for the Point Conception LNG Terminal Project.

MATERIALS-RELATED ASSUMPTIONS

\section{CONSTRUCTION}

It is expected that 15 percent of construction materials and equipment purchases will occur in the study area. The vast majority of these purchases will be cement and aggregate for the rectenna foundations. It is expected that. the aggregate will be supplied at or near the project site. The cement is expected to be purchased from cement plants in Kern or San Bernardino Counties, but for this report it has been assumed that all of the cement will be purchased from the Cal ifornia Portland Cement plant in Mojave. The Mojave plant is currently being expanded to a capacity of nearly two million tonnes of cement per year. While any one plant would be unlikely to commit its entire capacity to the construction of a single project, there is sufficient cement capacity in the Kern-San Bernardino County areas to supply the project (Evans, 1979).

The construction contractors are expected to locate branch offices in the Ridgecrest area for the duration of the construction period. Miscellaneous material and equipment expenditures associated with contractors and consultants are not included in project cost estimates. These costs are expected to be on the order of two percent of the projects non-labor costs, based on the projections made for the Western LNG Terminal facilities at Oxnard (Socio-Economic Systems, 1976) and the SOHIO Tanker Terminal Long Beach (POLB, 1976). One-half of the m1scellaneous expenditures are expected to occur in the Ridgecrest area, with the remainder occurring elsewhere within southern California. 


\section{OPERATIONS}

The annual operations expenditures for materials and equipment are projected to be $\$ 13$ million. These expenditures have not been disaggregated, so it is difficult to estimate the expenditures that will occur locally. For purposes of this report, it is assumed that 15 percent of operations non-labor expenditures will be spent locally (e.g. fuel, landscaping, paint).

\section{PUBLIC REVENUES}

\section{PAYROLL EXPENDITURE AND SALES TAXES}

Based on 1978 U.S. Bureau of Labor Statistics data, approximately 25 percent of payroll income goes to taxes and 35 percent of payroll income is spent on taxable purchases. The amount spent on taxable purchases would be approximately 48 percent of disposable income (payroll income minus taxes). The coso Geothermal Lease Program DES further assumed that only 70 percent of 1 ocal resident disposable income was spent within the study area. Since most of the expenditures made outside the local area would be taxable (e.g. automobiles and major appliances) it is assumed that only 40 percent of the local expenditures made by permanent inmigrants and two-year construction inmigrants would be taxable.

The weekly and daily commuters to the construction camp are expected to spend 35 percent and 5 percent, respectively, of their payroll locally. It is expected that these workers will be maintaining homes and families away from the construction site, so their expenditures in the local area would be much smaller. For the weekly commuters, it is assumed that 60 percent of their expenditures would be taxable, while all of the daily commuters expenditures are expected to be taxable.

\section{PROJECT OWNERSHIP}

For purposes of this report it is assumed that the Ground Receiving Station is owned and operated by the federal government. Public ownership simplifies the analysis in the following ways: first, the materials used to build such a facility would be exempt from taxation and secondly, the facility itself would be exempt from property taxation. The assumption of public ownership is not unreasonable since the Tennessee Valley Authority (TVA), Bonneville Power Administration (BPA), and Los Angeles Department of Water and Power (LADWP) etc.; all fall in this category.

In the event that a consortium of public and private utilities (or only private utilities) join together to build the GRS, then some (or all) of the materials purchases would be subject to sales tax. In addition, some percentage of the value of the site would be subject to property taxation. A brief analysis of this case is included as an addendum to the public revenues analysis (Section 4.9). 
UNITED STATES

DEPARTMENT OF ENERGY

WASHINGTON, D.C. 20585

OFFICIAL BUSINESS

PENALTY FOR PRIVATE USE, $\$ 300$
POSTAGE AND FEES PAID

U.S. DEPAATMENT OF ENERGY

DOE 360

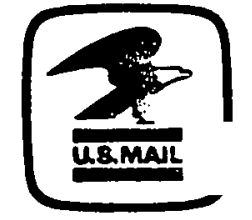

